


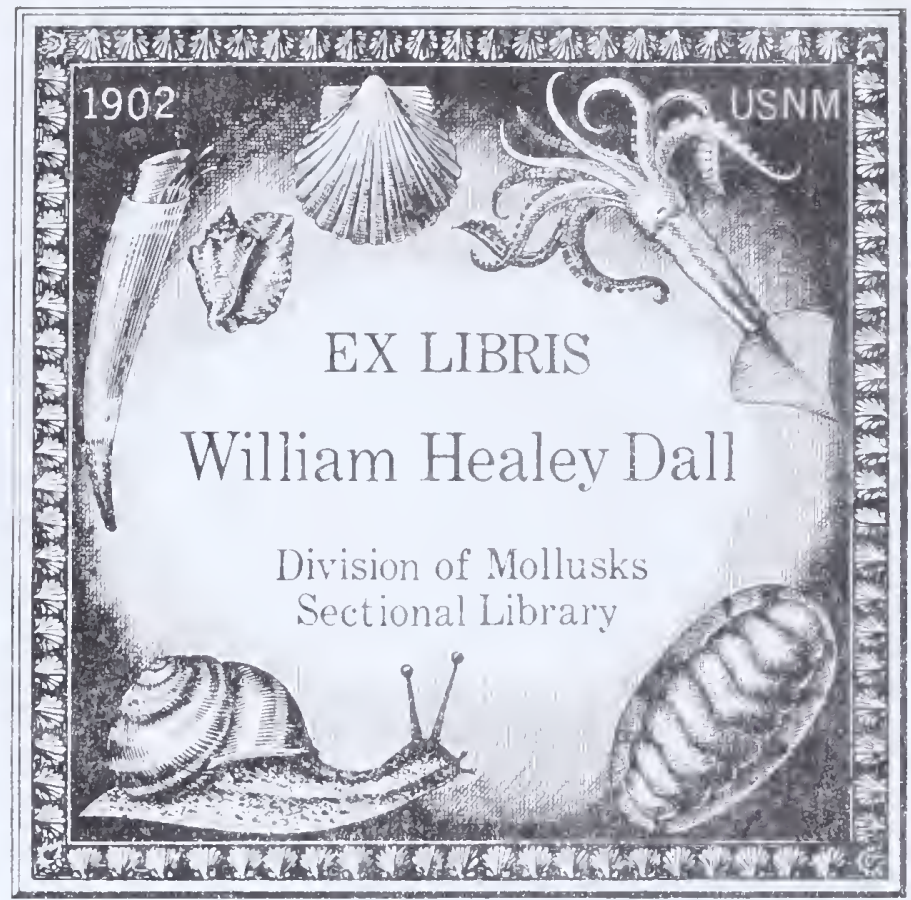


-

if - ia

finional L ur. 


DEPARTMENT OF THE INTERIOR

John Barton Payne, Secretary

UNited States Geological SURVEY

George Otis Smith, Director

Professional Paper 125

\section{SHORTER GONTRIBUTIONS TO GENERAL GEOLOGY}
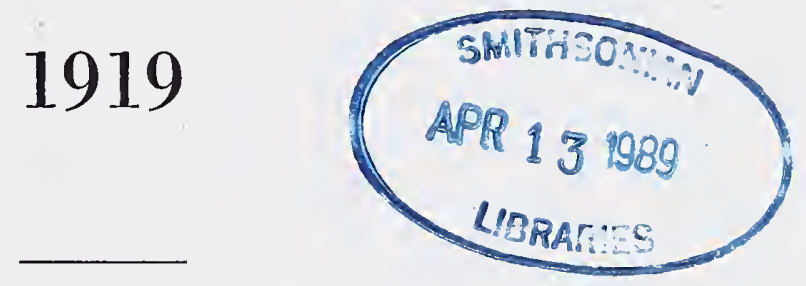

DAVID WHITE, ChiEF Geologist

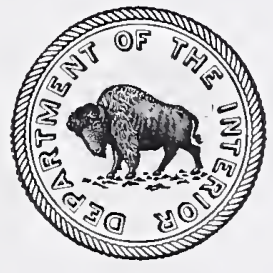

WASHINGTON

GOVERNMENT PRINTING OFFICE

1920 


\section{CONTENTS.}

[The letters in parentheses preceding the titles are those usel to designate the papers for advance publieation.]

Page.

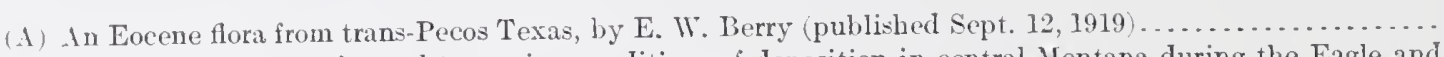

(B) Gradations from continental to marine conditions of deposition in central Montana during the Fagle and

Judith River epochs, by C. F. Bowen (published Oct. 20, 1919).........................

(C) Pliocene and Pleistocene fossils from the Arctic coast of Alaska and the auriferous beaches of Nome, Norton

Sound, Alaska, hy II. II. Dall (published Jan. 27, 1920) . . . . . . . . . . . . . . . . . . . . . .

(D) The American species of Orthophragmina and Lepidocyclina, by J. A. Cushman (published July 26, 1920)... Index.

\section{ILLUSTRATIONS.}

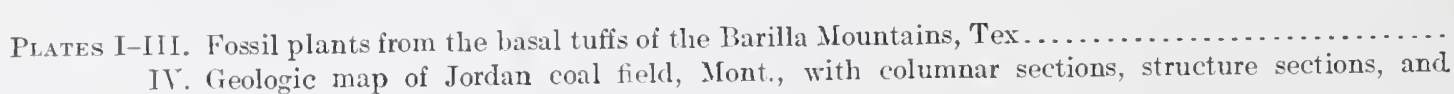

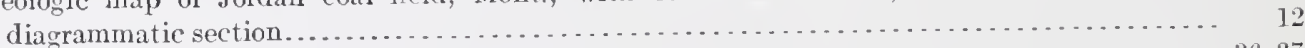

Y-YI Mlaskan fossils.

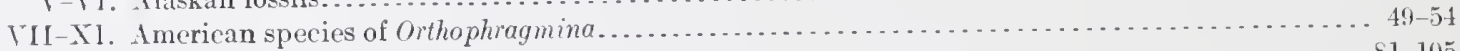

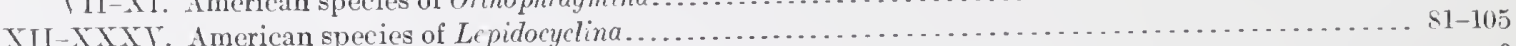

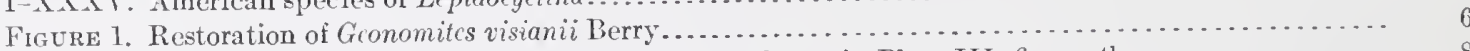

2. Restoration of the leaf of Ilex barillensis Berry shown in Plate III, figure 4 b................. S

3. Diagrammatic vertical section of Lepidocyclina.................................... 56

INSERT.

Page.

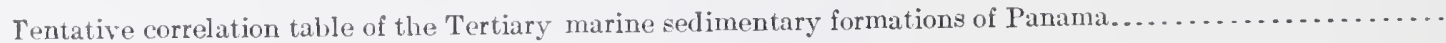




\title{
SHORTER CONTRIBUTIONS TO GENERAL GEOLOGY, 1919.
}

\author{
AN EOCENE FLORA FROM TRANS-PECOS TEXAS.
}

By Edward Wilber Berry.

INTRODUCTION.

During the fall of 1916 I received a small collection of fossil plants which had been obtained during a geologic reconnaissance of the trans-Pecos region of Texas, by Charles Lawrence Baker. A preliminary report was sent to Mr. Baker in November of that year and was quoted in his discussion of the geology of that region. ${ }^{1}$ I have since made a careful study of the collection, and although it contains only a few species the occurrence of fossil plants in this region is worthy of more definite and detailed record, especially as these plants enabled me to assign a definite age to the beginning of the igneous activity of the region and to establish correlations between the floras of the Mississippi embayment and the Rocky Mountain region.

A general account of the geology is contained in a recent paper by Baker and Bowman, already cited. The fossil plants, which are described in the following pages, were found in the basal tuffs of the Barilla Mountains between 10 and 15 miles south of Toyahvale and not far east of the main road from Toyah to Fort Davis. These tuffs are rhyolitic and not andesitic like those of the Denver Basin, which contain what appears to have been a contemporaneous flora, and they overlie unconformably beds which are of Pierre (Cretaceous) age, according to Baker and Bowman's determination of the geology.

One is tempted to assign all of what might be called the Laramide epoch of igneous activity along the Rocky Mountain front to the early Tertiary. There certainly appears to

1 Baker, C. L., and Bowman, W.F., Geologic exploration of the southeastern front range of trans-Pecos Texas: Texas Univ. Bull. 1753, pp. 123-124, 1917. have been synchroneity of inception of volcanism in the Denver, Raton Mesa, and Barilla Mountain regions, although farther north, in Montana, this activity appears to have commenced at an earlier date. Rhyolitic lavas overlie the coal-bearing San Carlos formation, which is of Upper Cretaceous age, and are present also in the Sierra Vieja of Texas. ${ }^{2}$ The basalts and phonolites of Uvalde and Travis counties intrude the Taylor marl (Upper Cretaceous) and are commonly considered to be of Tertiary age. Ash beds are also known to occur in the Texas Coastal Plain in late Eocene rocks, while on the other hand Udden reports volcanic tuffs in the Chisos country which are said to be interbedded in rocks of Navarro (Upper Cretaceous) age. It appears evident. that no reliance can be placed upon the volcanism as furnishing even an approximate datum plane for correlation, although it seems to be established that the Cordilleran orogenesis of the Tertiary was accompanied by volcanic activity on a grand scale.

\section{ENVIRONMENTAL CONDITIONS INDICATED BY THE FLORA.}

The flora here described was found about 340 miles west of the most westerly known outcrop containing fossil plants of Wilcox (lower Eocene) age, which is on Calaveras Creek in Wilson County, Tex.; 355 miles west of the most westerly known outcrop containing supposed Midway (Eocene) plants; 500 miles almost due south of the Raton Mesa country, in southeastern Colorado and northeastern New Mexico, which yields the flora of the Raton formation; and 670 miles south of the

${ }^{2}$ Vaughan, T. W., Reconnaissance in the Rio Grande coal fields of Texas: U. S. Geol. Survey Bull. 164, pp. 76-83, 1900. 
Denver Basin, which yields the flora of the Denver formation.

The tuffs containing this flora are thus about halfway between the Gulf Coastal Plain province and the rocks containing the southerumost known early Eocene floras along the present Rocky Mountain front. The flora is therefore of great interest for the information which its study affords regarding former climatic conditions in the region of its occurrence. Unfortunately the number of plants described is entirely too small to furnish precise paleoecologic data. At the same time certain leading features stand out very clearly despite the small number of forms represented. Baker and Bowman report an abundance of silicified logs from the tuffs, some as large as 3 feet in diameter. I have specimens of at least two species of petrified wood, which hare not yet been sectioned, but one is of an open-pored, dicotyledonous type and indicates climatic conditions quite different from the semiaridity that now prevails in trans-Pecos Texas.

All the identified forms from these tuffs, except the two new species, are common to the floras of either the Midway (?) or Wileox of the Coastal Plain or to the floras of the Raton or Denver of the Rocky Mountain province. This in itself is conclusive proof that the general climatic conditions in trans-Pecos Texas at that time were very similar to those of the coastal region to the southeast and of the interior region to the nortliwest. It also furnishes collateral evidence of the lack of a lofty mountain axis traversing the western interior at that time and shows that an interehange of life forms between the southeastern coastal region and the interior region was readily possible-a conclusion sustained by the considerable number of species known to be common to the early Tertiary floras of the Gulf Coastal Plain and those of the West (Denver, Raton, Fort Union, ete.).

The presence of two individually abundant species of palms in the flora from the Barilla Mountains, one a fan palm and the other a pinnately reined palm of the feather palm type, may be noted. 'The fan palm (Sabalites) appears to be most like the existing species of Sabal, the arborescent forms of which are now essentially coastal types that extend as far northward as latitude $35^{\circ}$. The botanie affinity of the fossil is, however, not certainly de- terminable, so that too much reliance can not be placed on the temperature and moisture requirements of the existing cablage palmetto. The other palm (Greonomites) represents a group of fossil forms typified in the existing flora by the genus Geonoma. Geonoma is now widely distributed in tropical and subtropical America and finds its maximum representation in the Amazon River basin. 'The fossil forms that have hitherto been referred to Geonomites are found in assemblages which indicate a range from humid warm temperate conditions (for example, those of the Denver flora) to what appear to have been typically tropical conditions (for example, those of the flora of the Italian lower Oligocene). Thus the presence of a small Geonomites in the Barilla Mountain region argues for an abundant supply of moisture, like that required by the Sabalites, and for a somewhat warmer temperature. The true measures for both temperature and moisture of this region in Eocene time may properly be considered as falling somewhere between the extremes indicated for these two types of palms.

'The Juglans, from its distribution during the Eocene as well as its general geologie history and the existing ranges of its modern representatives, may be taken to indieate warm temperate conditions of abundant but not excessive precipitation. The Asimina and Oreodaphne fit in nicely with such assumed conditions, for while both genera have tropical representatives, others of their species extend long distances into the Temperate Zone, as for example Asimina triloba Dunal, our common American papaw (not to be confused with the papaws of tropical elimes, which belong to a different family of plants), which is not uneommon in the Middle Atlantic States and is precariously hardy as far north as Massachusetts. The Ilex is the only known member of this flora that might have flourished in an environment of seanty rainfall, for it appears to hare been an evergreen form or at least of a coriaceous, eraporation-resisting type. 'The different species of Ilex, howerer, show a wide range in their elimatic requirements, and among the large number of existing species (more than 200) some have succeeded in occupying all the tropical and temperate regions of the globe except western North America, Australia, and New Zealand. In the United States the rari- 
ous species of holly are confined to the southeastern part of the country, and several reach their western limits in east or central Texas. The occurrence in the Barilla Mountains is therefore slightly beyond the normal western limit of range of the existing North American hollies, but as sereral species occur in the Tertiary floras of the Rocky Mountain province this occurrence is without any special significance.

Sunmarizing the indications afforded by the different species of plants found as fossils in the basal tuffs of the Barilla Mountains we may legitimately conclude that they point to warm temperate clinatic conditions with abundant precipitation and a plentiful supply of ground water. The actual temperatures can not be estimated, but hard winters may be regarded as very improbable, and there is nothing to indicate that mild winters such as occur at the present time in the Coastal Plain portions of the Carolinas and Georgia would have been prohibitive to the existence of the plants found in these tuffs. We may therefore picture the climatic conditions of trans-Pecos Texas during the period in which these plants flourished as corresponding to those found at the present time in the Coastal Plain portion of South Carolina.

\section{AGE OF THE FLORA.}

Although the determined forms are but six in number and two of the six are new to science, it is possible to reach somewhat definite conclusions regarding the age of the flora. In a subsequent paragraph the question of the exact horizon in the Eocene to which this flora should be referred is considered, but it may be noted here that the four species which occur outside of the Barilla Mountains are all found in the early Eocene of the Rocky Mountain province or in the corresponding beds of the Atlantic Coastal Plain, and on the other hand none of these forms are certainly found in the Upper Cretaceous of these or any other areas. It is true that Asimina eocenica has been recorded from the Montana group, but as I pointed out in discussing the presence of this species in the Midway (?) flora of Texas, ${ }^{1}$ the Upper Cretaceous material referred to this form is not identical with it, nor is it even referable to the genus Asimina, which is not yet known from the Upper Cretaceous.

1 Berry, E. W., U. S. Geol. Survey Prof. Paper 91, p. 14, 1916.
Similarly palm remains identified as those of Sabalites grayanus have been reported from the Upper Cretaceous of the Western States. Sabalites is, however, a form genus for fossil fan palms whose generic affinity is not certainly known, and it is thus without significance in the present connection, even if there were any adequate ground for identifying the western material as Sabalites grayanus, which there is not.

Another criterion in evaluating the present flora is furnished by the absence from it of certain elements. Although negative evidence is rightly considered of less value than positive evidence, it remains true that the types of plants that are most successful in resisting decay and those that almost invariably survive maceration and thus become fossilized in a recognizable form when they are at all common in any region are the gymnosperms. The Mesozoic has frequently been termed the age of gmynosperms or the age of conifers, from the preponderance of the remains of those plants in the floras of that era, and a considerable proportion of the older Mesozoic types survived throughout Upper Cretaceous time. These include the important genera Sequoia, Geinitzia, Araucaria, Widdringtonites, Brachyphyllum, Baiera, Czekanowskia, Moriconia, Androvettia, Thuites, and numerous others. Fragments of leafy twigs or cone scales are present in many coarse deposits in which all the other vegetable material has been reduced to unrecognizable débris. There are no traces of gymnosperms in the plant remains found in the basal tuffs of the Barilla Mountains, and from this negative evidence, which must be regarded as of considerable importance, I conclude that the age of these tuffs must be post-Cretaceous.

The genus Geonomites is distinctly a Tertiary type, for here again, notwithstanding the fact that species of Geonomites have been reported from the Upper Cretaceous of southwestern Texas, I have all the collected material and can state positively that Geonomites has never been found in the Upper Cretaceous deposits, the specimens that have been identified as representing this genus being obviously those of fan palms and not feather palms. The other three genera represented in the flora from the tuffs. of the Barilla Mountains-Ilex, Juglans, and Oreodaphne-are all genera with a known Upper Cretaceous ancestry and are commonly found among Upper Cretaceous collections of plants. 
Juglans offers but slight evidence either for flora. All the species of both floras are or against the Cretaceous or Eocene age of the dicotyledons. The fact that half of the six deposits, but the species of both hex and known speecies from the tuffs are found also Oreodapline are decisircly more morlern in in the Raton and Denver floras strongly their affinities than any Cretaceous forms reinforces this conclusion, for in a letailed known to me. Moreover, the present small comparison of these floras with that of the flora lacks altogether the commoner Upper Wilcox, I have given the evidence for considCretaceous dicotyledons, some of which would almost vertainly be present hasl the deposits been accumulated during the Upper Cretaceous epoch. I conclude from these faots that this flora is of early Eocene rather than of late Upper Cretaceous age.

The question of the exact horizon in the known Eocene with whioh these tufls should be correlated is, in the absence of more extensive collections, more or less debatable. It will be seen from the accompanying table of distribution that two or possibly three of the species, namely, Sabalites grayanus, Juglans rugosa, and Asimina cocenica (?), are present in the flora of the Raton formation of the southern Rocky Mountain region and that these same three species are also present in the Denver formation of Colorado. Asimina eocenica occurs in the Mitway (?) formation of the Texas Coastal Plain, and both Sabalites grayanus and Oreodaphne pseudoguiunensis are common in the deposits of the Wilcox group in the Mississippi embayment. The two lastnamed species are among the commoner species in the Wilcox flora, and the Sabalites is found at many localities and horizons in beds of Wiloox age. Both occur along the western shores of the Wilcox Mississippi embayment, and Sabalites has been found in beds of this age in western Texas. It is well recognized by most paleontologists that the commoner and more widely distributed forms of a flora or a fauna are less useful in critical comparisons than the less common forms-that is to say, the less common forms have a more precise value, as the commoner forms generally range through a longer period of time.

This fact and the further fact that only these two of the nearly 350 known Wilcox species hare been found in the tuffs of the Barrilla Mountains, whereas one of a known Miclway (?) flora of but 10 species oceurs in the still smaller flora from the Barilla Mountains, indicate very strongly that the latter flora should be correlated with the Midway (?)

ering them as approximately synchronous and older than the Wilcox flora. ${ }^{1}$

I conclude, therefore, that the basal tuffs in the Barilla Mountains are post-Cretaceous and pre-IVilcox in age and that they and the volcanic activity which they represent were probably contemporaneous with the floras and-similar volcanic activity reflected in the Raton and Denver formations and elsewhere in the Rocky Mountain region.

Range of fossil plents found in the tuffs of the Barilla Mountains, Tex.

\begin{tabular}{|c|c|c|c|c|}
\hline & 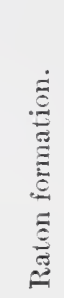 & 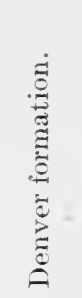 & 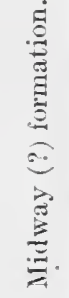 & 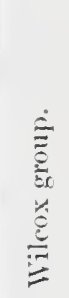 \\
\hline 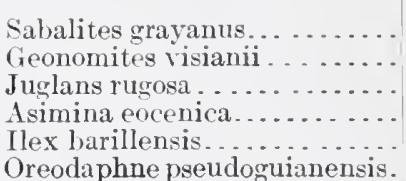 & $\begin{array}{r}x \\
\cdots \\
x \\
? \\
\ldots \\
\ldots\end{array}$ & $\begin{array}{l}x \\
\cdots \\
x \\
x \\
\cdots \\
\cdots\end{array}$ & $\begin{array}{l}\cdots \cdots \\
\cdots \\
\cdots \\
\cdots \\
\cdots\end{array}$ & $\begin{array}{l} \\
\cdots \\
\cdots \\
\cdots \\
\cdots \\
X\end{array}$ \\
\hline
\end{tabular}

\section{SYSTEMATIC DESCRIPTIONS.}

Phylum ANGIOSPERMOPHYTA.

Class MONOCOTYLEDONAE. Order ARECALES.

Family ARECACEAE.

Genus SABALITES Saporta.

Sabalites grayanus (Lesquereux) Berry (?).

Plate I; Plate III, figure 5.

Sabal grayana Lesquereux, Im. Philos. Soc. Trans., vol. 13, p. 412, pl. 14, figs. 4-6, 1869. (Not Lesquereux, 1871, 1874, 1876, 1878, or Knowlton, 1900.)

Sabalites grayanus (Lesquereux) Berry, U. S. Geol. Survey Prof. Paper 91, p. 177, pl.12, figs. $1-3$; pl. 14, fig. 1, 1916.

Knowlton, U. S. Geol. Survey Prof. Paper 101, p. $288,1918$.

Flabellaria coceniea Lesquereux, The Tertiary flora, p. 111, pl. 13, figs. 1-3, 1878 .

1 Berry, E. W., U. S. Geol. Survey Prof. Paper 91, p. 148, 1916. 


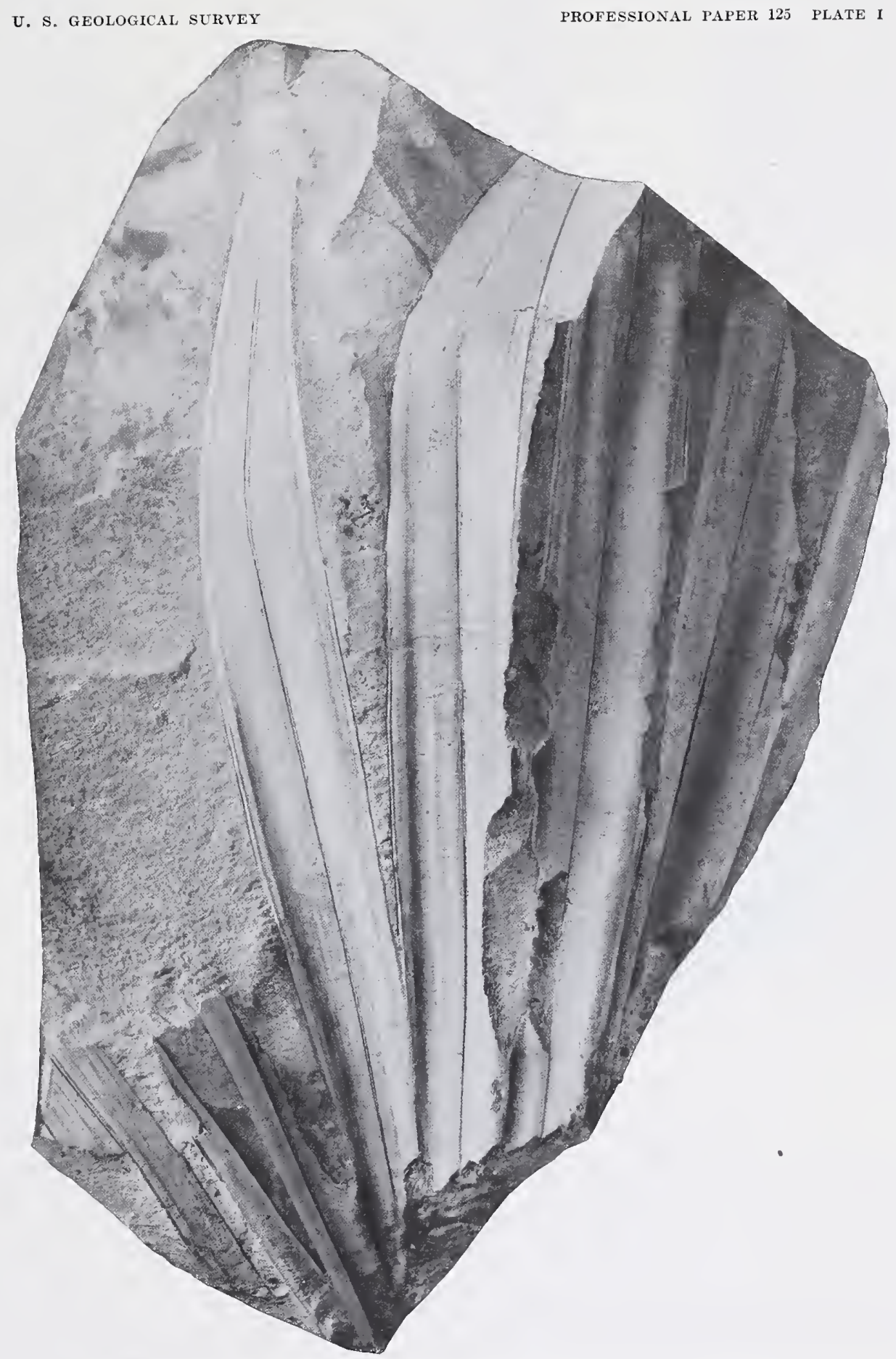

FOSSIL PLANT FROII THE BASAL TUFFS OF THE BARILLA MOUNTAINS, TEX.

Sabalites grayanus (Lesquereux) Berry (?). 


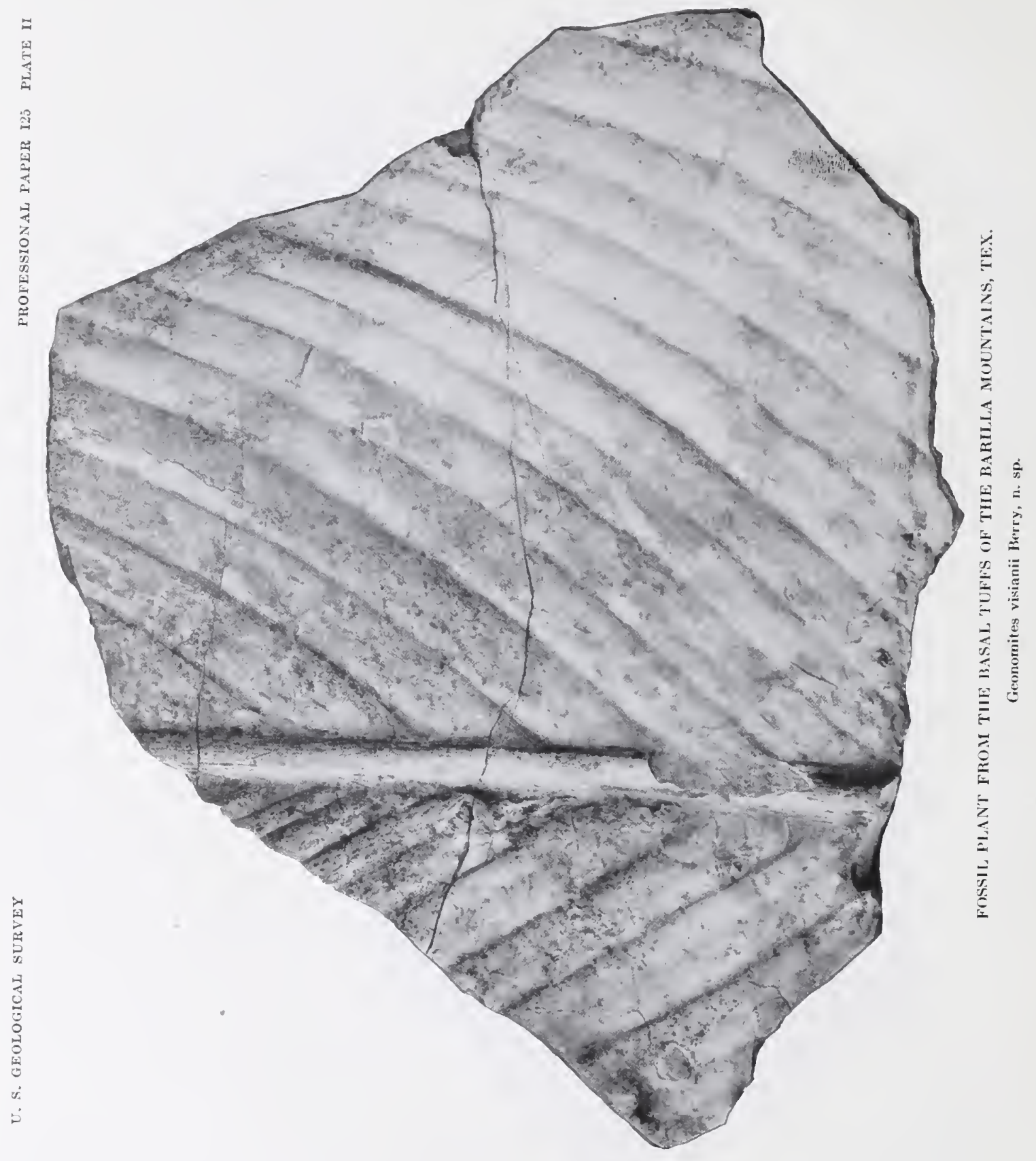


U. S. GEOLOGICAT SURVEY

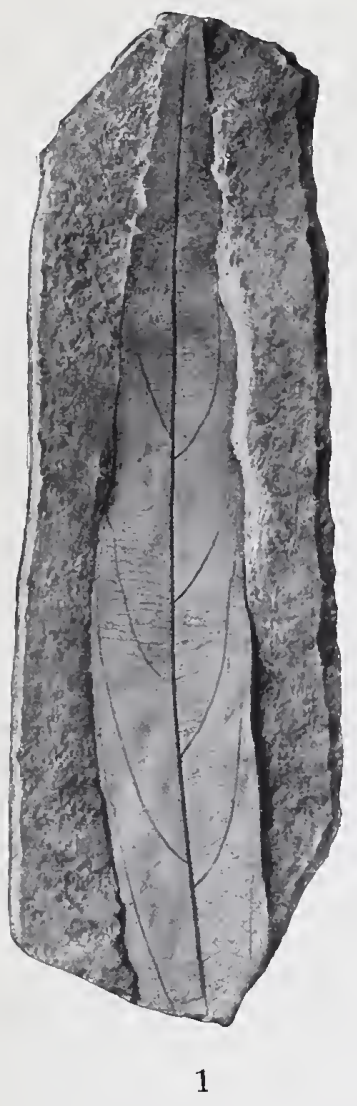

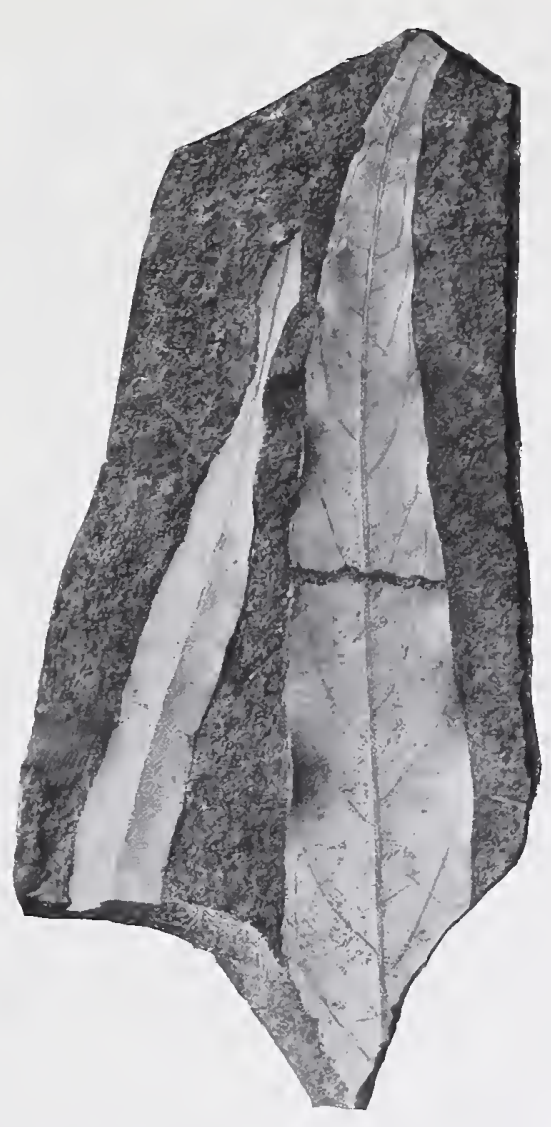

2

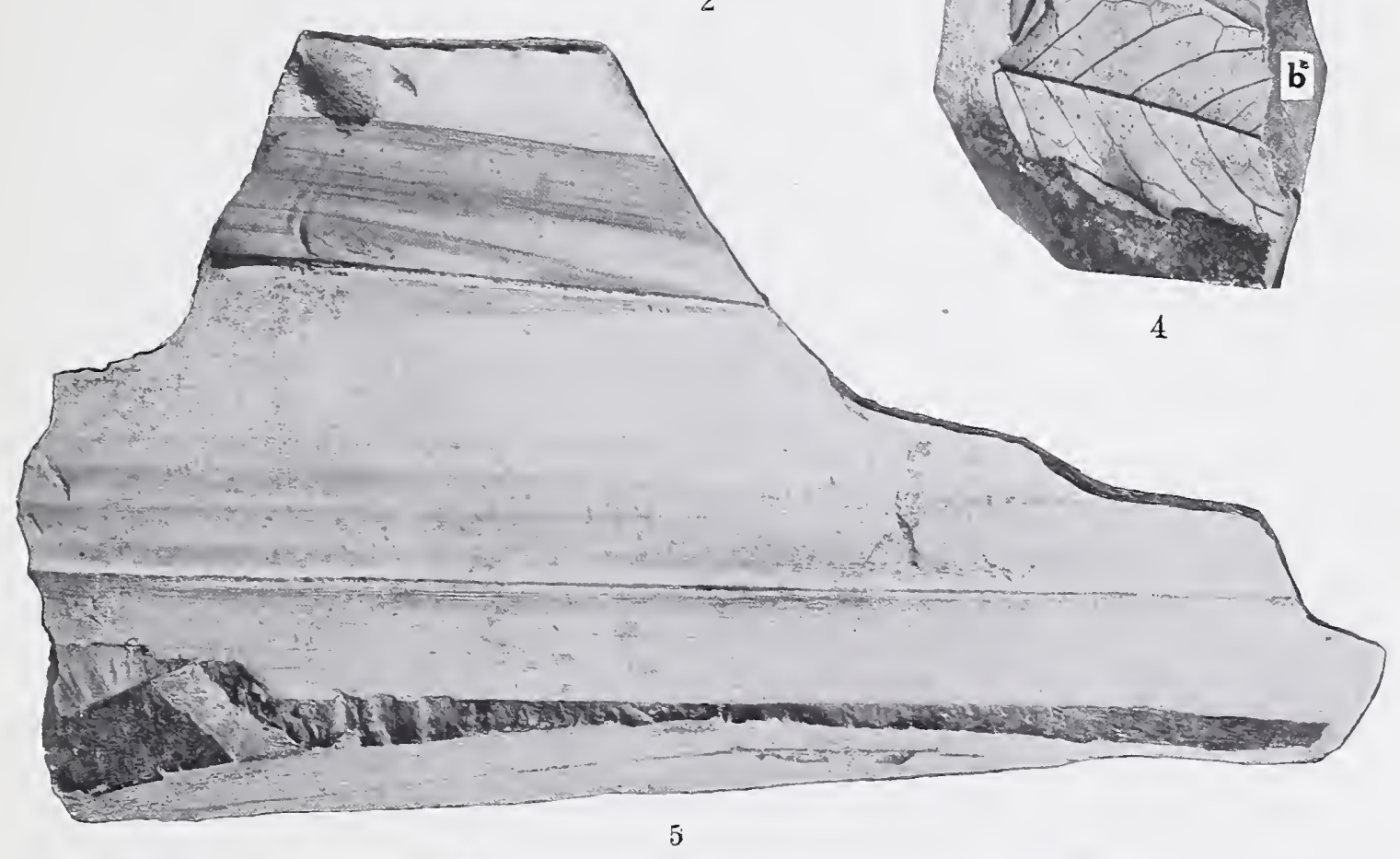

FOSSIL PLANTS FROM THE BASAL TUFFS OF THE BARILLA MOUNTAINS, TEX.

1-3, 4a, Oreodaphne pseudoguianensis Berry; 4b, Ilex barillensis Berry, n. sp.; 5, Sabalites grayanus (Lesquereux) Berry (?). 

Leaves of fan palms are the most abundant fossils in the basal tuffs of the Barilla Mountains. The material is fragmentary, and as it represents both large and small leaves more than one species may be represented. It has seemed best, however, to consider all the specimens collected as representing different-sized leaves of a single species, as no differential characters other than those of size can be distinguished.

It is with considerable hesitation that I identify these remains as belonging to this species, and possibly instead of representing Sabalites grayanus they should be referred to Sabal ungeri (Lesquereux) Knowlton, which is exceedingly common in the Raton formation of Colorado and New Mexico and possibly occurs elsewhere in the Eocene of the western United States. There is also the further possibility, alluded to by Knowlton, that the two may represent a single species, and in any erent the convergence of characters is marked and they are at least closely related. The following description of Sabalites grayanus is quoted from my account of the Wilcox occurrence:

Leaves of large size but mostly fragmentary. Petiole long and stout, unarmed, enlarged at the base of the leaf, and tapering into an extended and gradually narrowed acumen, which is not visible on the upper surface of the leaf, where the petiole is broadly rounded and a short and inconspicuous ligule is developed. From the manner of preservation and attitude of the rays on some of the specimens it is inferred that the acumen was recurved, as it is in the existing Sabal palmetto (Walter) Roemer and Schultes. Rays very numerous, about 100 in number, a few reduced basal ones on each side free, the remainder united for a variable distance above the base. Their dimensions and the relative thickness of the venation are variable features dependent on the size of the leaves. The largest specimens seen have thick carinate stout-veined rays, 5 centimeters in maximum width. They increase in size from the base of the leaf upward, and individually they are narrow at their point of attachment, widening medially and becoming gradually narrowed into long acuminate tips. Venation characters variable, largely dependent on the size of the leaves and the condition of preservation of the epidermis in the fossil specimens. In well-preserved material there are four or five relatively thin intermediate veins. Between each pair of veins there are six to eight fine veinlets, which are not visible except in well-preserved specimens.

Sabalites grayanus is a somewhat protean species which was described by Lesquereux from the Wilcox clays ("Eolignitic") of Lafayette County, Miss. None of Lesquereux's ${ }^{1}$ type material appears to be extant at the present time, but it seems probable that it came from a locality near Oxford. Within the next ten years after the publication of his original description of this species Lesquereux identified it from a large number of localities in Colorado, Wyoming, and Vancouver Island. Nearly all of this material is now in the United States National Museum and in my judgment does not represent this species. Knowlton ${ }^{1}$ has recorded five species of Sabal-like palms from the Raton formation of southeastern Colorado and northeastern New Mexico. Palm leaves are the most abundant fossils in that formation, and the wealth of this somewhat intractable material (so far as generic and specific differentiation is concerned) affords abundant testimony regarding the climatic conditions and the abundance and variety of the palms in the early Eocene history of the Rocky Mountain region.

\section{Genus GEONOMITES Visiani. \\ Geonomites visianii Berry, n. sp. \\ Plate II.}

Leaves of medium size, ovate in general outline, becoming cleft distad at maturity. Length (estimated) about 75 centimeters; maximum width (estimated) about 40 centimeters. Rachis very stout, as much as 1 centimeter in diameter in the preserred material, very prominent on the under surface of the leaf, where it is semicircular in section, not keeled; flat or channeled on the upper surface. Laminae inserted on the lateral margins of the upper surface of the rachis, consisting of 75 to 100 undifferentiated rays on each side, which are united for all or a greater part of the distance to the margin. The rays are but slightly if at all plaited and do not contract proximad. They diverge from the rachis at angles averaging about $30^{\circ}$ and curve upward slightly and regularly as they proceed toward the margin. They are 6 to 8 millimeters in width, with a thin principal vein, and 10 to 12 thin parallel veins on either side of the principal vein. (See fig. 1.)

The texture of these leaves appears to have been coriaceous, for although their substance has mostly disappeared during fossilization they

${ }^{1}$ Knowlton, F. H., U. S. Geol. Survey Prof. Paper 101, pp. 288-291, $1 \mathrm{Kn}$ 


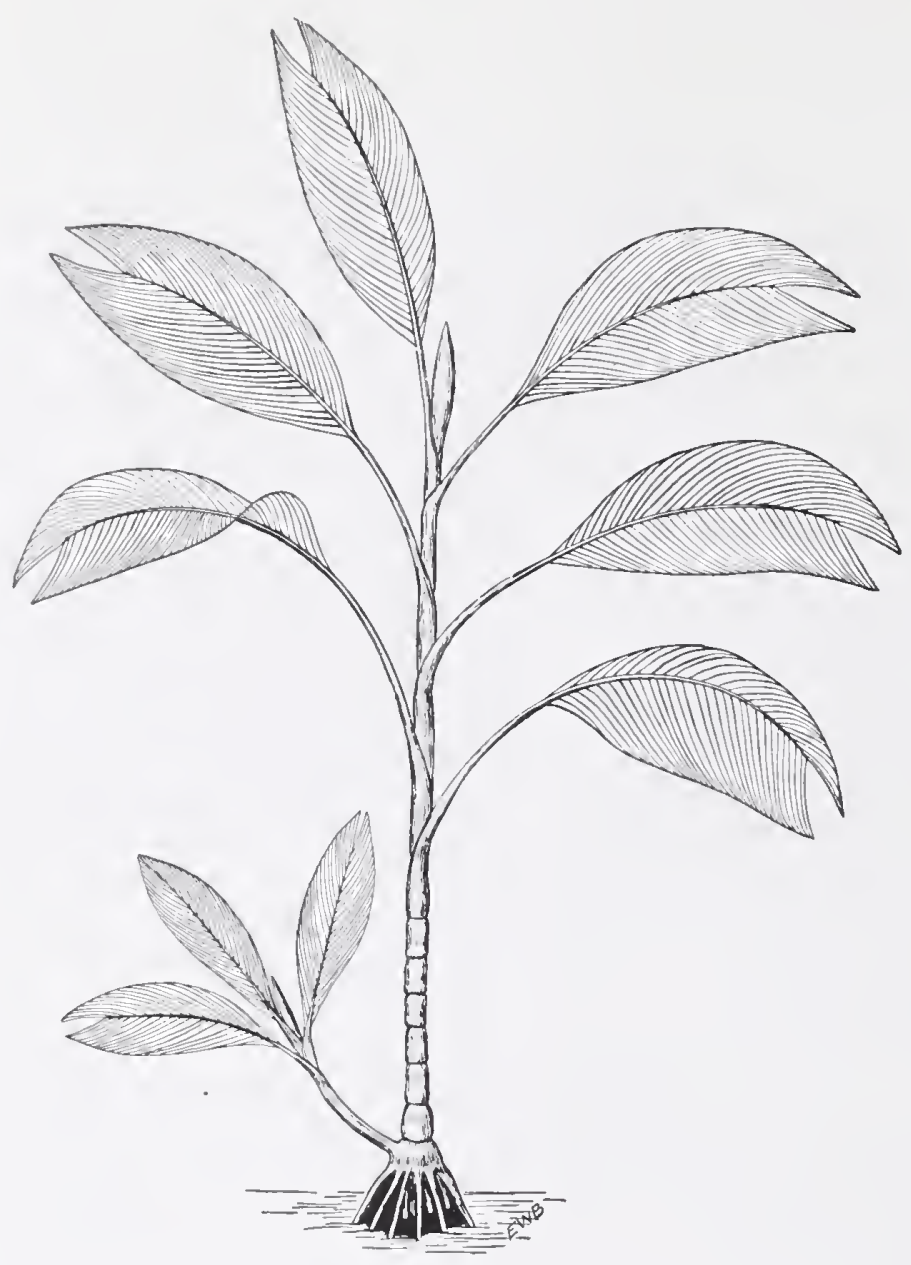

Figure 1.-Restoration of Gconomities visianii Berry, n. sp. One-fifteenth natural size.

representatives of the tribe Geonomeae. This tribe includes at least ten genera, three of which, all monotypic, are natives of western Africa. The remaining genera, containing 98 per cent of the known species, are widely distributed in tropical and subtropical Ameriea. Most of these seven genera are small, eontaining from one to five existing species. The only large genus of the tribe is Geonoma, which comprises between 80 and 100 existing species that extend from the Antilles and southern Mexico through Central America, along the eastern base of the Andes to Bolivia, and along the east coast of South America to Rio de Janeiro. Their center of clistribution at the present time is in the basin of the Amazon. They are prerailingly small stemless or short-stemmed palms and are undoubtedly of American origin. The fossil representatives of the Geonomeae comprise several Eocene and Oligocene forms of both North America and Europe which hare been referred to the genus Maniearia of Gaertner; three forms referred to Geonoma; and six forms referred to Geonomites. The earliest known species of both Geonoma and Geono-

lie almost perfeetly flat in the tuffs, whereas all the other associated plant remains are more or less bent or contorted. It is of course possible that the tuffs maly represent both water-laid and wind-blown rolcanie ash, a conelusion that appears probable in regard to the matrix of most of the dicotyledonous leares found at this locality, which is slightly different in appearance from the matrix of the Geonomites and is suggestive of certain similar leaf-bearing clays of the Fayette and Catahoula sandstones of eastern Texas that are known to have had such an origin, at least in part. On the other hand, no lithologic differences are observable between the Geonomites matrix and that inclosing the bent remains of Sabalites.

'The genus Geonomites, which receives its name from its resemblance to the existing geuus Geonoma of Willdenow, is more properly considered to represent the undifferentiated ancestry or the generically indistinguishable fossil mites occur in the early Eocene (Raton and Denver formations) in Colorado and New Mexico. The species Geonomites schimperi, from Yellowstone Park, has been referred to the Laramie formation, but the age of the outcrop is uncertain and is probably Eocene. This species has also been recorded from the Tertiary of Contra Costa, Calif. Geonomites goldianus Lesquereux, a Denver speeies, has been reported from the Eocene of Wyoming. A speeies has been reported from the supposed Upper Cretaceous along the Rio Grande in Texas, but I have reexamined the material, which proves to be that of a distorted fan palm of the Sabalites type, in no wise related to Geonomites. The earliest known European form, the type of the genus, comes from the lower Lutetian of Italy. A second species, referred to Geonoma by its describer, comes from the Oligocene of Italy, and a third, likewise referred to Geonoma, comes from the lower Miocene of Switzerland. 
Although the geologic record is thus incomplete, it would seem to indicate a tropical origin for the tribe, possibly in late Upper Cretaceous time, a spread northward far into western North America during the early Eocene, and an invasion of southern Europe, possibly extending to tropical Africa, during the middle Eocene or slightly later. An opinion as to whether the tribe migrated to the Eastern Hemisphere across the Tropics or in higher latitudes is not warranted in the present state of our knowledge.

Geonomites has not yet been found in the extensive Eocene floras from the shores of the Mississippi embayment which I have described. The fact that the bulk of these plants have been collected from the old eastern shores of this Eocene gulf may or may not be significant. The absence of Geonomites in the Wilcox flora rather lends support to the riew that the basal tuffs of the Barilla Mountains are somewhat older than the Wilcox-that is, they are of Midway age. I also conclude that the Raton and Denver formations along the present Rocky Mountain Front Range are likewise older than the Wilcox.

\section{Class DICOTYLEDONAE. \\ Order JUGLANDALES. \\ Family JUGLANDACEAE. \\ Genus JUGLaNs Linné.}

Juglans rugosa Lesquereux.

Juglans rugosa Lesquereux, Im. Jour. Sci., vol. 45, p. 206, 1868; The Tertiary flora: U. S. Geol. Survey Terr. Rept., vol. 7, p. 286 , pl. 83 , figs. 4,5 ; pl. 84 , figs. 1-9; pl. 85, figs. 1, 2, 1878. (Not Lesquereux, 1888, or Hollick, 1899.)

Knowlton, U. S. Geol. Survey Prof. Paper 101, p. 293, pl. 112, fig. 4, 1918.

This somewhat variable species had a wide range during the Eocene in western North America and has been recorded from Canada, Montana, Wyoming, Yellowstone Park, Colorado, California, Oregon, and New Mexico. It is distinctly a lower Eocene type and is a characteristic form in the floras of the Denver and Raton formations. It was recorded from the lower Eocene of the Mississippi embayment region by both Lesquereux and Hollick, but these occurrences do not represent this species, which so far as known did not exist in that region until later in the Eocene. The species is represented by over a dozen specimens, mostly fragmentary, in the basal tuffs of the Barilla Mountains.

\section{Order RANALES. \\ Family ANONACEAE. \\ Genus ASIMINA Adanson.}

Asimina eocenica Lesquereux (?).

Asimina eocenica Lesquereux, U. S. Geol. and Geog. Survey Terr. Ann. Rept. for 1872, p. 387, 1873; The Tertiary flora, p. 251, pl. 43, figs. 5-8, 1878.

Berry, U. S. Geol. Survey Prof. Paper 91, p. 14, 1916.

Three or four not very perfect specimens in the basal tuffs of the Barilla Mountains are questionably referred to this species. It was described by Lesquereux in 1878 in the following terms:

Leaves very entire, lanceolate, equally gradually tapering downward to a short, thick petiole and upward to a point; nervation pinnate, camptodrome. I have seen a large number of specimens of these leaves, varying in size from 8 to 15 centimeters long and from $2 \frac{1}{2}$ to 4 centimeters broad in the middle, where they are widest, and there oblong, gradually narrowing upward and downward. The consistence of the leaves is somewhat thick but not coriaceous; the midrib thick, the lateral veins numerous, parallel, all under the same angle of divergence of $50^{\circ}$, slightly curved in traversing the lamina, generally simple or branching once toward the borders, which they follow in a series of bows, formed by anastomoses with veinlets or branches. The nervilles are distinctly marked, at least upon some well-preserved specimens like the one of figure 8 ; they are generally joined in the middle of the areas by oblique veinlets, forming large equilateral meshes, the ultimate areolation being indiscernible. These leaves differ especially from our $A$. tritoba by their oblonglanceolate shape, those of the living species being generally enlarged upward and more distinctly oblong-obovate and proportionally broader. The nervation compared in both the small and the large leaves of the living species fully agrees with that of these fossil leaves, the lateral veins becoming closer and more distinctly marked in the small leaves, as it is in figure 5 . It is the same with the tertiary intermediate nerves, which are scarcely, if ever, distinctly marked upon the small or middle-sized leaves of the papaw, while they appear, if not numerous, at least perfectly distinct, in the large ones. A fruit referable to this genus is described in the Eocene [Tilcox] flora of the Mississippi as Asimina leiocarpa Lesquereux.

The species Asimina eocenica is common in the Denver formation of Colorado and occurs also at Carbon and Black Buttes, Wyo. It is also present in the Midway (?) Eocene of Texas. It has been recorded by Knowlton from the Montana group, but this identification I regard as incorrect. It is probably present in the Raton formation, being not 
unlike leaves from the Ratom whieh have heen referred to the European Tertiary species Juglans acuminata N1. Braun. Possibly also some of the leaves that have been referred to Nectandra lancifolia (Lesquereux) Berry may represent this species of Asimina.

\section{Order SAPINDALES.}

Family ILICACEAE.

Genus ILEX Linné.

Ilex barillensis Berry, n. sp.

Plate III, figure $4 \mathrm{~b}$.

Sessile or subsessile, slightly inequilateral leaves of relatively small size, about 6 centimeters in length and 2.6 centimeters in maximum width at or below the middle; with a pointed tip, a broadly rounded abrupt base, a conspicuously toothed margin, and a subcoriaceous texture. The marginal teeth are large, remote, and irregularly spaced, unlike on the opposite margins; some approach a dentate form, others are serrate, and others salient-serrate. The midrib is stout, rather prominent, ourved. Secondaries fairly stout, about eight subopposite to alternate pairs; they diverge from the midrib at approximately regular intervals and are camptodrome, sending tertiary branches into the marginal teeth where those are present. Tertiaries form an open areolation tending to be quadrangular in appearance. (See fig. 2.)

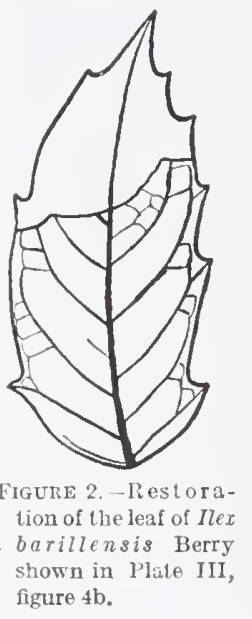

This species, which is obviously new, is unfortunately represented by a seanty anount of material. In general form it greatly resembles some of the existing western liveoaks, as for example Quercus agrifolia Née and Quercus chrysolepis Liebmann, or the so-called black oak, Quercus emoryi Torrey, of the mountain ranges of the arid Southwest. The venation, however, is unlike anything oceurring in Quercus, in which the areolation is closer meshed and different in character and the secondaries taper more abruptly, are less regularly spaced or curved, and are cras-

ICf. Knowlton, F. H., U. S. Geol. Survey Prof. Pa per 101, pl. 90, fig. $1,1918$. pedodrome in the toothed-margin forms. On the other luand, the venation in both its gross and minute features is typical of the genus Ilex, and the general form is not unlike that of numerous morlem species of that genus, as for example the serrated forms of the English holly or our own lex opaca Aiton. Moreover, the plants associated with the fossil species lend credence to the view that the habitat was somewhat similar to that required by our modern holly, namely, that it was a bottom-land or mesophytic species, rather than one of exposed, arid, or cool habitat. While Ilex opaca ranges from Massachusetts to Florida it is rare in the Allegheny Mountains and finds its optimum habitat in the bottoms of southern Arkansas and eastern Texas.

\section{Order THYMELEALES. \\ Family LAURACEAE. \\ Genus OREODAPHNE Nees.}

\section{Oreodaphne pseudoguianensis Berry.}

Plate III, figures 1-3, $4 \mathrm{a}$.

Oreodiphne pseudoguianensis Berry, U. S. Geol. Surrey Prof. Paper 91, p. 305, pl. 81, figs. 3, 4, 1916.

This species and Sabalites grayanus are by far the most abundant forms in the basal tuffs of the Barilla Mountains. The Oreodaphne was described by me from the Wilcox Eocene of Louisiana and oontemporaneous beds in Temessee in 1916 as follows:

Leaves narrowly elongate-lanceolate and falcate in general outline, the apex gradually attenuated and the base somewhat shorter, aruminate. Length ranges from 15 to 18 centemeters. Maximum width, in the lower half of the leaf, 1.7 to 2 centimeters. Margins entire, very faintly undulate. Leaf substance very thick. Texture decidedly coriaceous. Petiole long, stout, and curved. about 3 centimeters in length. Midrils stout, prominent on the lower surface of the leaf. Secondaries stout, prominent on the lower surface of the leaf: three or four coinmonly subnpposite pairs of the same charact-r, alove which in the attenuated tip are numerous thin reduced pairs, diverging at wide angles. The basal pair are opposite and subbasal, diverging from the midrib at angles of about $20^{\circ}$, rather straight in their course and close to and parallel with the lower lateral margins. The succeeding two or three pairs, generally subopposite, arise at intervals of 1.5 to 2.5 centimeters. They diverge at slightly wider angles, about $30^{\circ}$, and are regularly curved and ascending, becoming parallel with the lateral margins, along which they ascend for a considerable distance, and are eventually camptodrome. The second- 
aries diverge at wider and wider angles and are more curved in the upper half of the leaf until in the tip they become very thin and diverge at angles of about $70^{\circ}$, running straight about halfway to the margin, where they turn abruptly upward to form wide arches to the adjacent superior secondaries. Tertiary venation largely immersed, consisting of transverse, slightly curved nervilles.

This species is one of the most distinctive fossil species of Lauraceae known, and as it is so much more abundant in the tuffs of the Barilla Mountains than at the type localities the foregoing description may be somewhat amplified, particularly as regards the limits of variation and the areolation. Thus the smallest leaves have a length of but 8 centimeters and a maximum width of but $S$ millimeters, while the maximum width of the largest specimens is 2.25 centimeters. The areolation is fine meshed and the nervilles, both those at approximately right angles to the midrib and those forming wide angles with them, appear more prominent, giving the areolation a decidedly quadrangular appearance, although in reality the areolation is prevailingly polygonal.

The appearance of these leaves is well shown in the accompanying illustrations, and they distinctly corroborate the comparisons made between the type and the existing Oreodaphne guianensis Aublet, of northern South America. In fact, but for the greater development of the lower secondaries in the fossil, the two are scarcely to be differentiated. 



\title{
GRADATIONS FROM CONTINENTAL TO MARINE CONDITIONS OF DEPO- SITION IN CENTRAL MONTANA DURING THE EAGLE AND JUDITH RIVER EPOCHS.
}

\author{
By C. F. Bowen.
}

\section{INTRODUCTION}

The large amount of geologically unexplored territory in western Rosebud and Dawson counties, Mont., led to an examination by the writer of a part of this territory for the purpose of getting general information on its stratigraphy and structure. The region proved to be one of considerable geologic interest.

The work demonstrated (1) that pronounced dome structure exists in a region heretofore supposed to be underlain by nearly flat-lying beds; (2) that the Eagle sandstone, which is a thick formation farther west, thins eastward and disappears near the western border of the area herein described; (3) that the Judith River formation, previously known only as of fresh-water and brackish-water origin, grades into a marine formation in passing eastward from the shore line of the sea along which it accumulated; and (4) that east of the meridian of $107^{\circ} 30^{\prime}$ (approximately) the deposition of marine sediments was continuous throughout the Colorado and Montana epochs of Upper Cretaceous time in this part of the Great Plains region.

The area herein considered comprises about 1,200 square miles in Rosebud and Dawson counties and extends from Forsyth northward for a distance of 40 miles, thence westward to Musselshell River. Its geographic position is shown on the key map (Pl. IV).

The area was mapped on a scale of 1 mile to the inch. Horizontal control was based on the land survey of the General Land Office and was obtained by stadia and triangulation. A stadia traverse along the Bearpaw-Lance boundary was carried throughout the field. From this traverse triangulation points were established which furnished control in other parts of the field. Elevations were obtained by means of vertical angles, the initial eleration being a point on the Chicago, Milwaukee \& St. Paul Railway a few miles west of Forsyth. $131049^{\circ}-20-2$
The field sheets thus prepared and the land plats obtained from the General Land Office furnished the data from which the accompanying base map (Pl. IV) was prepared. This map shows the principal streams and roads of the area, as well as the geologic formations exposed. The formation boundaries are represented by solid lines where they are accurately determined and by broken lines where, because of lack of exposures or for other reasons, they could be located only approximately.

The writer was assisted in the field by C. A. Bonine, to whom much credit is due for the results obtained.

\section{SURFACE FEATURES.}

The area is a part of the Missouri Plateau of the Great Plains, and its surface features are those produced by the erosion of such a region in a semiarid climate. Erosion has changed a comparatively level surface into one dissected by streams and surmounted by numerous buttes. This sculpturing is most pronounced along Musselshell River, where in a belt 1 to 3 miles wide intricately dissected badlands have been formed. In most parts of the area the sandstones of the Judith River and Lance formations form conspicuous ridges that rise abruptly from the lower and more nearly level surfaces occupied by the shale formations. The irregularities of the surface are due chiefly to differences in erosion induced by the unequal resistance of the formations.

\section{GEOLOGY. STRATIGRAPHY.}

GENERAL SECTION.

The formations exposed in this area range in age from Upper Cretaceous to Tertiary (?) and include the Colorado shale (upper part), Eagle sandstone, Claggett and Judith River formations, Bearpaw shale, and Lance formation. With the exception of the Eagle sand- 
stone, which does not extend east of Mussel- in the immediate vicinity, but have been peneshell River, these formations are behieved to be trated by the drill to a depth of about 2,500 continuous throughout the area, but the Juclith Rirer changes from a fresh-water formation in the western part of the area to a marine formation in the eastern part. In other words, feet below the top of the Colorado shale in a deep well put down at Vananda, in T. $7 \mathrm{~N}$., R. 38 E., by the Chicago, Milwaukee \& St. marine conditions prevailed over the eastern thickness eonsists of the dark-gray to blark

Gologic formations in the area herrin discussed.

\begin{tabular}{|c|c|c|c|c|}
\hline System and series. & Group. & Formation. & $\begin{array}{l}\text { Thickness } \\
\text { (feet). }\end{array}$ & Charaster. \\
\hline Quaternary. & & & & $\begin{array}{l}\text { Alluvial gravel, sand, and silt along Yellowstone } \\
\text { and II usselshell rivers and some of the smaller } \\
\text { streams. }\end{array}$ \\
\hline
\end{tabular}

\begin{tabular}{c|c|c|}
\hline $\begin{array}{c}\text { Tertiary (?) } \\
\text { cene? }) .\end{array}$ & (Eo- & Lance formation.
\end{tabular}

Brown, irregularly bedded sandstone, alternating with "somber" gray shale. Upper part (2.5 feet or more) is somewhat sandy, forming a transition to the Lance. This transition phase is probably what has been recognized as Fox Hills on Hell Creek about 35 or 40 miles farther north.

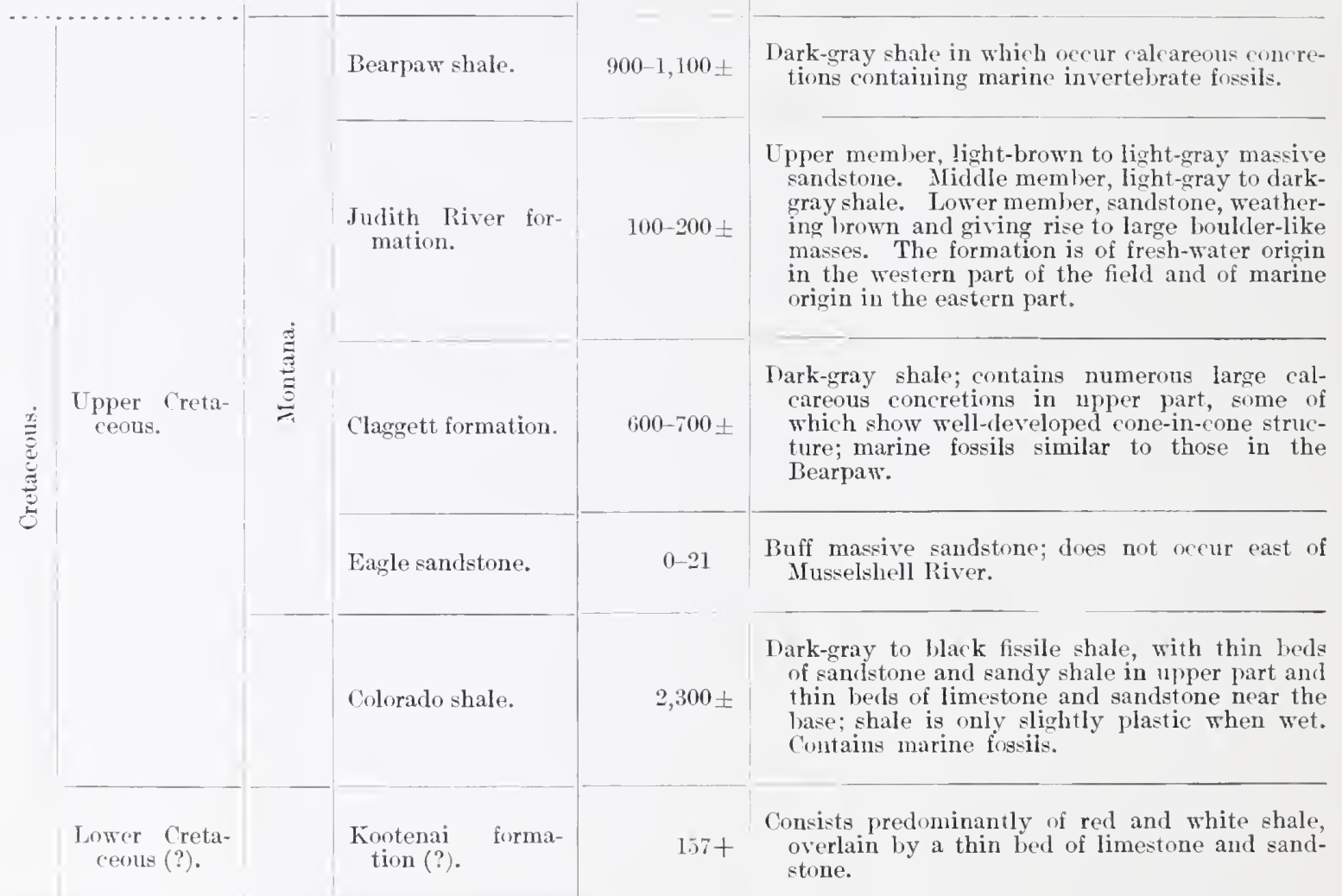

part throughout the Montana epoch, whereas in the western part a temporary recession of the sea allowed the accumulation of freshwater deposits. These conditions are illustrated in the diagrammatic and generalized sections shown on Plate IV.

Rocks below the upper part of the Colorado shale are not exposed in this field or anywhere shale of the Colorado, but the lower 157 feet seems to represent some underlying formation, probably the Kootenai.

The accompanying table presents in condensed form the sequence, character, and thickness of the exposed formations and of those penetrated by the drill in the well at Vananda, a detailed log of which is given on page 13 . 


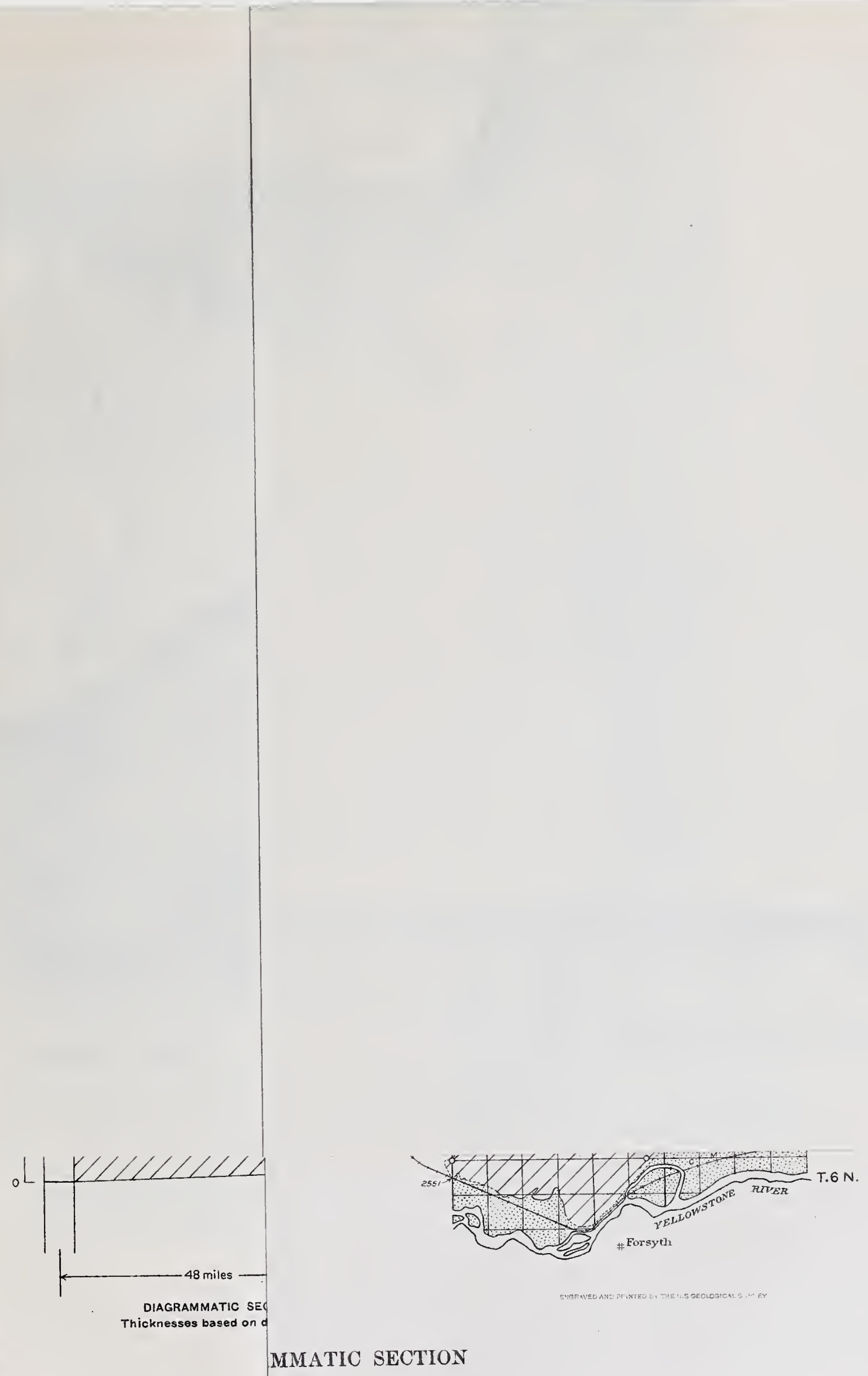



Log of well drilled by the Chicago, Mitwaukee \& St. Paul Raitway Co. at Vananda, in sec. 5, T. 7 N., R. 38 E., Mfont., between October 23,1913 , and October 17, 1914.

[Elevation of mouth of well, 2,704 feet above sea level.]

\begin{tabular}{|c|c|c|c|}
\hline Formation. ${ }^{a}$ & Driller's description. & $\begin{array}{c}\text { Thick- } \\
\text { ness. }\end{array}$ & Depth. \\
\hline Judith River formation. $b$ & 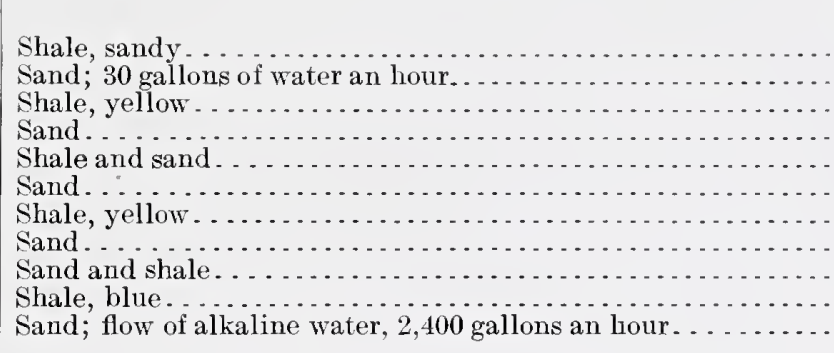 & $\begin{array}{r}\text { Fect. } \\
23 \\
7 \\
16 \\
11 \\
24 \\
8 \\
16 \\
14 \\
24 \\
46 \\
26\end{array}$ & $\begin{array}{r}\text { Fet. } \\
23 \\
30 \\
46 \\
57 \\
81 \\
89 \\
105 \\
119 \\
143 \\
189 \\
215\end{array}$ \\
\hline Claggett shale. $c$ & Shale; disintegrates when exposed to air. . . . . . . . . . . . . & 685 & 900 \\
\hline Colorado shale. & 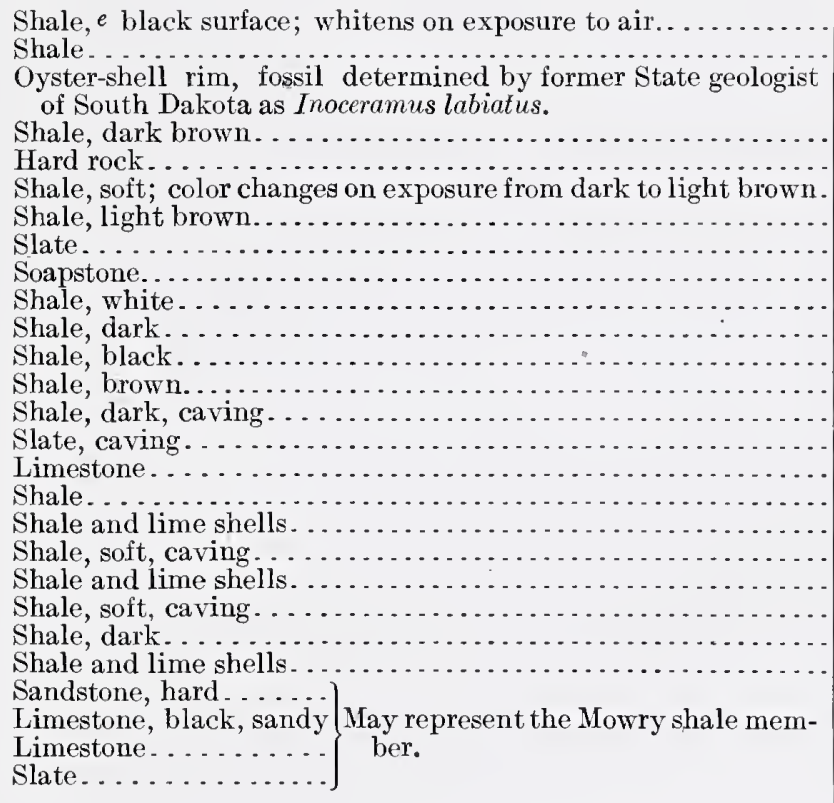 & $\begin{array}{r}140 \\
907 \\
5 \\
107 \\
29 \\
32 \\
40 \\
40 \\
13 \\
23 \\
45 \\
19 \\
100 \\
31 \\
19 \\
41 \\
239 \\
15 \\
35 \\
20 \\
105 \\
35 \\
103 \\
32 \\
18 \\
42 \\
55\end{array}$ & $\begin{array}{l}1,040 \\
1,947 \\
1,952 \\
2,059 \\
2,088 \\
2,120 \\
2,160 \\
2,200 \\
2,213 \\
2,236 \\
2,281 \\
2,300 \\
2,400 \\
2,431 \\
2,450 \\
2,491 \\
2,730 \\
2,745 \\
2,780 \\
2,800 \\
2,905 \\
2,940 \\
3,043 \\
3,075 \\
3,093 \\
3,135 \\
3,190\end{array}$ \\
\hline Kootenai (?). & 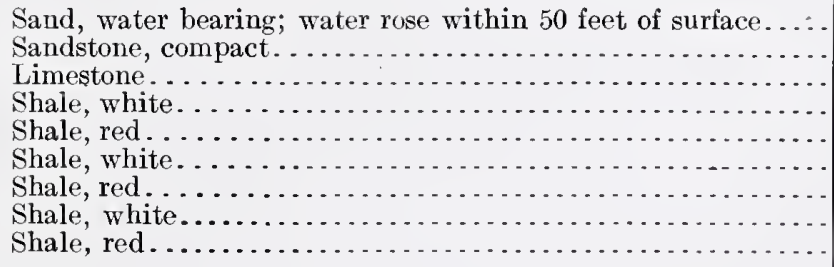 & $\begin{array}{r}10 \\
30 \\
19 \\
23 \\
7 \\
8 \\
27 \\
8 \\
35\end{array}$ & $\begin{array}{l}3,200 \\
3,230 \\
3,249 \\
3,272 \\
3,279 \\
3,287 \\
3,314 \\
3,322 \\
3,357\end{array}$ \\
\hline
\end{tabular}

a Correlation revised by author.

$b$ Called Lance in log furnished by railway company.

$c$ Called Pierre in log furnished by railway company.

$d$ In view of the lithologic similarity between the claggett and Colorado the position of this boundary must be regarded as uncertain.

$\boldsymbol{e}$ Called Niobrara in log furnished by railway company. 
CRETACEOT'S SYSTEM.

KOOTENAI (?) FORMATION.

That part of the Kootenai (?) penetrated by the drill in the Vananda well eonsists in descending order of 40 feet of sandstone, 19 feet of limestone, and 98 feet of red and white shale in alternate layers. There is no information arailable as to whether these beds are of fresh water or marine origin; in lithologic aspeet, however, the beds, especially the red and white shates, are similar to the fresh-water Kootenai (Lower Cretaceous) of the Great Falls field. In that field the Kootenai as described by Fisher ${ }^{1}$ is 400 to 500 feet thick and consists predominantly of elay, with thin intercalated beds of sandstone and limestone, but contains valuable beds of coal in the lower part and a basal sandstone from which building stone is obtained.

\section{COLORADO SHALE.}

The Colorado shale is the oldest formation exposed in this area. It consists of dark-gray to black fissile shale, with some thin bands of sandstone and sandy shale in its upper part, and according to the record of the Vananda well has more or less sandstone and a thin bed of limestone at the base. 'The shale contains large calcareous concretions in which fossils occur; some of the sandstone bands are also distinctly fossiliferous. The formation has a total thickness, as interpreted from the log of the Vananda well, of about 2,300 feet. It probably includes the time equivalents of both the Benton and Niobrara formations. In this part of Montana there appears to be no recogrnizable lithologic distinction between these two formations, and they are therefore grouped together under the name Colorado shale. It may be, however, that detailed paleontologic work would show the existence of a Niobrara fauna in the upper part of the Colorado shale, even though no lithologic distinction exists. Weed ${ }^{2}$ and Stanton and Hatcher ${ }^{3}$ have already pointed out a general resemblance between the fauna of the upper part of the Coloralo in the vieinity of Fort Benton and the fauna of the Niobrara. It might be possible,

1 Fisher, C, 1., Geology of the Great Falls coal field, Mont: U. S. Geol. Survey Bull. 356, pp. 22, 30-35, 1909.

2 Weed, W. H., U. S. Geol. Survey Geol. Itlas, Fort Benton folio (No. 55), p. 2, 1899

${ }^{3}$ Stanton, T. W., and IIatcher, J. I3., Geology and paleontology of the Judith River beds: U. S. (ieol. Survey Bull. 257, P). 63, 64, 1905. therefore, on purely paleontologic grounds to separate the Colorado of this area into the Benton and Niobrara, as in Nebraska, Colorado, South Dakota, and Wyoming.

In the eastermmost areas just mentioned the Niobrara formation consists chiefly of limestone; farther west it is a calcareous buff shale; and apparently still farther west it loses its calcareous aspect, becoming a typical clay shale that is somewhat arenaceous. This is the sort of change to be expected in a formation of this kind when traced toward the source of its constituent materials.

The Colorado differs from the overlying Claggett in being darker and more fissile and in becoming only slightly plastic when wet; because of this last characteristic the local term "gumbo" is not generally applied to it.

The Colorado occupies an area of about 350 square miles in the central part of the Poreupine dome, which lies principally west and south of the eastern part of this area. It also occupies another small dome extending westward from a point a few miles east of Musselshell River. Except in the small area west of the Musselshell, where the Eagle can be recournized, the Colorado and Claggett have not been differentiated on the accompanying map.

\section{EAGLE SANDSTONE.}

The Eagle, which forms a prominent and persistent lithologie unit farther west, is represented in this area by a buff medium-grained sandstone consisting of quartz, feldspar, and black chert with a small amount of mica inclosed in a calcareous matrix. It ranges from a knife-erlge to about 20 feet in thickness. The sandstone is recognizable as a distinet unit at the western margin of the area, from which its outcrop has been traced northwestward and southwestward for many miles. In these more western areas the formation ranges from 200 to 300 feet in thickness, but it thins eastwarl, so that near the east side of T. 15 N., R. 29 E., where the sandstone is exposed in a clean-cut face, it is only 21 feet thick, with marine shale both above and below. From this place the formation can be traced eastward for about 2 miles, and in that distance the sandstone is seen to become more and more interlaminated with thin bands of shale in its lower part. The sandstone passes under an old river terrace 
about halfway between the western margin of the area and Musselshell River and is not exposed farther east, but at the Musselshell, where there is a clean-cut exposure from the Lance down into the Colorado, the Eagle is either lacking or is represented by a sandstone 3 feet thick.

The pinching out of the Eagle is not due to an unconformity but to the seaward thinning of a shoal deposit laid down during a recessional stage of the Cretaceous sea and later covered by an off-shore deposit as the sea deepened and the shore line was shifted farther west.

\section{CLAGGETT FORMATION.}

The Claggett consists of 600 to 700 fect of dark-gray shale containing numerous calcareous concretions in which invertebrate fossils occur. The shale is but slightly consolidated and becomes very plastic when wet, so that it is commonly referred to as "gumbo." Crystals of selenite are more or less abundant in the shale and in places accumulate in considerable quantities on weathered slopes. At the top of the formation there is a zone that is especially prolific in large calcareous concretions, many of which show a well-developed cone-in-cone structure. This feature, so far as the writer is aware, is peculiar to the Claggett throughout a large part of Montana and does not occur in either the Colorado or the Bearpaw. It therefore constitutes one criterion for the recognition of the Claggett in central Montana.

JUDITH RIVER FORMATION.

Character and thickness.-The Judith River formation, as originally defined, ${ }^{1}$ includes fresh and brackish water beds lying above the marine Claggett and below the Bearpaw. This definition was given before the full extent of the formation was known. The work of the season of 1918 has shown that in the area described the fresh-water deposits when traced eastward grade in to marine deposits of the same lithologic character. In this paper the term Judith River is used to include both the fresh-water deposits exposed in the western part of the area and their equivalent marine deposits in the eastern part.

The fresh-water facies may be considered as made up of three parts - a lower division of

${ }_{1}$ Stanton, T. W., and Hatcher, J. B., Geology and paleontology of the Judith River beds: U. S. Geol. Survey Bull. 257, pp. 33-34, 1905. massive brownish, poorly cemented sandstone, a middle division of ash-gray shale, and an upper division of grayish-white to brown massive to heary-bedded sandstone. The total thickness of this facies of the formation is about 185 feet.

The marine facies likewise has a threefold character which corresponds in every way to the fresh-water divisions except that the middle shale member is darker. The upper sandstone is of a light-brown color in the eastern part of the field but farther west changes to light gray or dirty white; the lower sandstone is prevailingly brown on weathered surfaces. The marine facies has a thickness of about 125 feet near the head of Big Porcupine Creek; it is reported as 200 feet thick in the Vananda well and may be thicker than that, as it is believed that the mouth of the well is below the top of the formation; but on the east side of the field the thickness probably does not exceed 100 feet.

Detailed sections of these two facies are given below.

Section of Judith River formation (marine) in sec. $8, T .12 \mathrm{~N}$, R. $38 \mathrm{E}$.

Sandstone, massive, yellow to brown (marine shells

and Halymenites) ............................. 20

Talus, sandy, probably sandstone.............. 30

Shale, gray to yellow....................... 20

Sandstone, massive, gray at top and full of Halyme-

nites, lower part not well exposed............... 45

Section of Judith River formation (fresh-water) on west bank of Musselshell River, in sec. 16, T. 15 N., R. 30 E.

Shale, Bearpaw.

Feet.

Sandstone.............................. 29

Shale, light gray.......................... 15

Shale, carbonaceous...................... $8_{2}^{1}$

Sandstone .............................. 8

Shale, gray; carbonaceous in upper part........ 13

Sandstone............................... 9

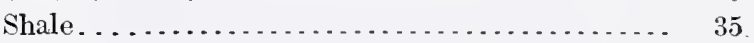

Sandstone............................ 13

Shale, light gray...................... 15

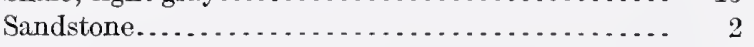

Shale.................................. 3

Shale, carbonaceous..................... 8

Sandstone............................. 31

Shale, Claggett, dark gray, sandy at top, transition. $\quad-\frac{1}{1891}$

Composition.-As revealed by a study of thin sections the sandstones of both the freshwater and marine facies of the formation are as similar in microscopic appearance as they 
are in outward physical appearance. They are arkosic and consist of angular, subangular, and rounded grains of orthoclase, plagioclase, quartz, and black chert, with small amounts of muscovite and biotite, inclosed in a matrix or cement of ealeite, which is more or less stained with iron oxide. Grains of limestone are numerous in one specimen of fresh-water origin and are rather well rounded; but they are not observed howerer in any of the other specimens examined. I rather surprising feature is the slight alteration of a considerable proportion of the feldspar. Many of the grains, especially of the plagioclase rariety, are perfectly fresh and clear and show no sign of kaolinization. In the sections examined the calcite constitutes 50 per cent or more of the bulk of the rock; of the granular material feldspar is in general the most abundant, followed by black chert and quartz, which vary in amount, in some specimens the one and in some the other predominating. Another interesting feature is the small proportion of well-rounded grains. The grains of chert and quartz are subangular to rounded, whereas those of fekdspar are predominantly angular and give to the thin sections the appearance of being made up largely of angular to subangular fragments. This marked angularity does not aecord well with the highly assorted condition of the material, which is remarkably uniform in size and free from silt or fine particles. This highly assorted condition suggests considerable agitation, either by wares or by currents, whereas the angularity of the grains suggests but a moderate amount of abrasion. It is probably to be attributed to the clearage of the feldspar and the smallness of the grains rather than to the amount of abrasion of the particles. The texture is fine and raries somewhat in the different specimens, the grains ranging from about 0.075 to 0.2 millimeter in areruge diameter.

Relutions.-The Judith River is conformable with both the underlying and overlying formations. In the western part of the area the fresh-water facies overlies about 600 feet of the Claggett, including a sandy transition zone about 35 feet thick, and is in tum orerlain by 1,000 to 1,100 f'eet of Bearpaw shale. The marine lacies overlies 700 feet (Vananda well record) of the Claggett and is overlain by about 900 feet of the Bearpaw. In other words, the marine and fresh-water facies are at the same stratigraphic horizon, and the orerlying shale is a unit from the locality of the one to that of the other. The marine phase represents the seaward extension of the continental deposits and marks the maximum retreat of the sea during this stage of minor oscillation.

The Bearpaw shale includes the marine shate lying between the Judith River and Lance formations. It consists chiefly of darkgray shale that is similar in lithologic eharacter to the shale of the Claggett except that so far as observed it contains no concretions showing cone-in-cone structure. In the upper part of the formation there is a sandy zone 25 feet or more thick which consists of sandy shale and some thin sandstones forming a transition to the Lance. This is probably the representative of the sandy shale from which, on Hell Creek, 35 or 40 miles farther north, Barnum Brown obtained a Fox Hills fauna and which he therefore designated the Fox Hills formation. ${ }^{1}$ I small collection of marine fossils, all representing a single species of Lingula, was obtained by the writer in a sandstone that caps a small outlier in the SW. $\frac{1}{4}$ sec. 1, T. 11 N., R. $32 \mathrm{E}$. This sandstone is probably near the top of the transition zone just described. The species of Lingula obtained is not sufficiently diagnostic for purposes of close time correlation. It therefore does not establish the existence of the Fox Hills at this place, but it indicates that the sandy transition zone at the top of the Bearpaw is marine.

The thickness of the Bearpaw ranges from 1,000 or 1,100 feet in the western part of the area to about 900 feet in the eastern part. As determined by the fossils which occur in it, the formation is of Montana age and is equiralent to a part of the Pierre and possibly includes also the representative of the Fox IIills. Its correlation in this area is rendered eertain not only by its included fossils but by its continuity with the undoubted Bearpaw of other regions.

1 Brown, Barnum, The Hell Creek beds of the Upper Cretaeeous of Montana: Am. Mus. Nat. Hist. Bull., vol. 23, p. 829, 1907. 
TERTIARY (?) SYSTEM.

LANCE FORMATION.

Character and thichness.-The section given below is fairly representative of the lower part of the Lance formation, the only part extensirely represented in this area. This part consists mainly of brownish massive to hearybedded sandstone and interbedded light-gray to dark-gray shale. Some of the sandstone layers are well consolidated and form protecting caps to the softer underlying beds. Large rustybrown loglike concretions are common. Though brown is the prevailing color, some of these sandstones are dirty white to gray. Ripple marks and cross-bedding are common structural features.

The interbedded shale is light-gray to leadgray and contains some carbonaceous members, though these are rare. The shale is unconsolidated and weathers rapidly where not protected by the more resistant sandstone. Thin layers of impure fossiliferous limestone occur in a very few places.

In the northeast corner of the area the beds above described are overlain by a zone consisting chiefly of "somber" gray shale with interbedded layers of carbonaceous shale and yellow and brown sandstone. Some of the sandstone layers, which are as much as 20 feet thick, are well consolidated and resemble in every way the sandstones in the lower part of the formation.

There is no abrupt change between this member and the lower member described above. They seem to represent continuous deposition and a gradual change from the conditions faroring the accumulation of sandstone to those faroring the accumulation of shale. This shale member, although not definitely included in the Lebo shale member of the Little Sheep Mountain field, seems to be identical in character with it. So far as the writer was able to ascertain, this member pinches out or at least thins markedly farther west; however, more detailed work on the overlying beds and a careful study of the extent and character of the various phases are necessary in order to establish their continuity and determine their relations.
Section of a part of the Lance formation exposed in Table Butte, in the SE. $\frac{1}{4}$ sec. $32, T .7 N ., R .41 \mathrm{E}$.

Sandstone, massive, cross-bedded, containing clay balls............................... 25

Shale, becoming sandy toward top. . . . . . . . . 80 Shale, carbonaceous......................... 1

Shale, yellow to drab........................ 70

Sandstone, massive, buff; contains bone fragments and

small scattering pebbles. . . . . . . . . . . . . . . . 30

Shale, buff.............................. 20

Sandstone, massive, brown.................. 10

"Somber" and yellow clay shale, alternating....... 60

Composition.--The sandstones of the Lance, including those interstratified in the darkshale member deseribed above, as well as those which make up the bulk of the lower distinctly sandy portion of the formation, are arkosic and are shown on microscopic examination to consist of the same material as the sandstones of the Judith River formation, the only difference being the higher degree of oxidation of the material of the Lance. In all the thin sections examined the principal granular minerals present are feldspar, chert, quartz, muscovite, and biotite, named in the order of their abundance; these are embedded in a matrix of calcium carbonate, which constitutes 50 per cent or more of the bulk of the rock. Grains of limestone are also sparingly present in some specimens. The feldspar, including orthoclase, plagioclase, and microcline, is commonly the predominant granular mineral. Many of the grains are comparatively fresh and unaltered and show cleavage or crystal boundaries and beautifully marked striations; others are more or less cloudy and opaque from the development of kaolin. Most of them are angular or subangular, well-rounded grains being exceptional. The chert, which in the hand specimen is gray or black, is invariably present. In the thin section it is clear and transparent and exhibits a cryptocrystalline texture. It is variable in amount, being in some specimens almost as abundant as the feldspar but in others less abundant than the quartz. The grains of chert show a much more marked tendency toward rounding than those of feldspar. 
The quartz occurs in subangular to rounded ; grains. It is rariable in amount, being almost wholly absent in one specimen and in others constituting 25 per cent or more of the granular material. Muscorite is present in notable amount and is easily recognized in the hand specimens; biotite is also sparingly present. The calcite, which constitutes the matrix of the rock, shows a finely crystalline texture. It is commonly more or less stained and obscured by limonitic material, which in most of the specimens also occurs to a greater or less degree in distinct grains. Like the sandstones of the Judith River, those of the Lance are medium grained, and their grains are of fairly uniform size, showing a marked degree of assortment.

Age and correlation.-Paleontologists are not agreed as to the age of the Lance formation, the invertebrate and vertebrate fossils being regarded as related to Cretaceous types, whereas the plants are regarded as of Fort Union age. Under these circumstances the Geological Surrey has only provisionally assigned the Lance to the Tertiary system.

The formation is identified in this area and its relations are established by (1) the finding of Triceratops remains near the base of the formation at Castle Butte, northwest of Forsyth, and the occurrence in it of many fragments of dinosaur bones in other parts of the area; (2) its stratigraphic position between the Bearpaw shale and the Fort Union formation; and (3) its continuity with beds that undoubtedly belong to the Lance in other parts of Montana.

Distribution and surface features.-The Lance formation occurs at the southern, eastern, and northern margins of this area and extends beyond the area in each of these directions. In general it occupies a zone from 1 mile to several miles broad, its width depending on the attitude of the beds and the stage of erosion.

The outcrop of the formation has a marked effect on land forms. Its lower part produces a prominent ridge which rises abruptly, in some places almost precipitously, from the lower areas occupied by the Bearpaw. From the margin it extends as a dissected upland studded with buttes, pinnacles, and other features characteristic of the weathering of moderately consolidated beds in a semiarid region.

\section{STRUCTURE.}

In its broad general relations the structure in this part of Montana is anticlinal and represents the southeastward extension of the Big Snowy anticline. More locally the eastern part of the area occupies the eastern and northern flanks of the Porcupine dome, around which the beds have a quaquaversal dip and are therefore in this area inclined southward, eastward, and northward. As shown on the accompanying map, the dips in this part of the area range from $1^{\circ}$ or $2^{\circ}$ to $40^{\circ}$. This dome is separated by a broad, shallow transverse syncline from a pronounced anticline in the vicinity of Musselshell River. On the west side of the syncline the strata dip $15^{\circ}$ $25^{\circ} \mathrm{E}$.; on the east side the westward dip is not more than $2^{\circ}$ or $3^{\circ}$. West of this cross syncline the Big Snowy anticline is the dominant structural feature. Around the point of this anticline the Judith River formation dips from $5^{\circ}$ on the south limb to $45^{\circ}$ on the north. These steep dips do not continue for any considerable horizontal distance in the direction of the dip, as the overlying Lance rarely shows dips of more than $10^{\circ}$ along its border and within half a mile lies essentially flat. It is a noteworthy fact throughout the area that the steeply dipping beds become approximately horizontal within short distances. The features above described are shown graphically by the structure sections along the lines $A B C$ and EF on Plate IV.

Besides the main structural features outlined above there are local irregularities, such as the anticlines in T. 14 N., Rs. 32 and 33, 37 , and $38 \mathrm{E}$.

\section{SOURCE OF THE SAND.}

The feature that most impresses one who studies the sandstones of the Lance and Judith River, and, so far as can be judged by a microscopic examination, this applies also to the Eagle sandstone, is their illentity in mineral composition and the relative abundance of the predominant minerals. The abundance of feldspar, the invariable occurrence of black chert, commonly in considerable amount, together with quartz and mica, and the almost complete absence of other granular constituents strongly suggest derivation either from a common source or at least from rock of similar composition, and the uniformity in 
texture and assortment ccrtainly points to similar physiographic conditions of accumulation. This striking resemblance is still more remarkable in view of the fact that the formations are separated from one another by several hundred feet of marine shale. The conclusion is inevitable that the oscillations which give rise to the alternate deposits of shale and sandstone during the Upper Cretaceous were of a gentle, rhythmic type.

This conclusion at once raises a question as to the age of the Rocky Mountain orogenic disturbance. 'The petrographic evidence may ultimately have more weight in deciding this question than has yet been assigned to it. At present this evidence seems to warrant the belief that there was no great physical break between the deposition of the formations underlying the Lance and that of the Lance and to corroborate the evidence afforded by the attitude of the Lance and Fort Union formations, namely, that the present Rocky Mountains are of post-Fort Union rather than preLance age.

As to the probable source of the material, it is hardly profitable in our present state of lnowledge to speculate further than to say that it was evidently derived from the land mass to the west that is supposed to have been in existence during the Cretaceous period. It would yield interesting data, however, if observations of this character were extended over the entire region involved, and it might then be possible to form more definite conceptions, not only as to the source of the material, but also as to the conditions of its accumulation.

\section{UPPER CRETACEOUS HISTORY.}

Variations in the character of sediments inrolving changes from sandstone to shale and from marine to fresh-water deposits imply corresponding changes in physiographic conditions during the period of their accumulation and therefore furnish a basis for the interpretation of the past history of the region in which they occur.

Such changes occurred in north-central Montana during the Upper Cretaceous epoch. The area herein described happens to be favorably situated in that it furnished more exact evidence than has heretofore been available as to the magnitude of some of these oscillations of the sea and as to the extent and character of the formations involved.

An understanding of these conditions will be facilitated by a study of the diagrammatic section on Plate IV which extends from Black Butte, at the north end of the Judith Mountains, about 48 miles west of this area, southeastward to the longitude of Glendive, a total distance of about 210 miles. Section $A$ is compiled from measurements made by W. R. Calvert in the Lewiston field and those made by the writer in 1912; sections B, F, and G are compiled from data collected by the writer while examining the area herein described; and information regarding conditions at Glendive is based on the record of a well put down near that place by the Northern Pacific Railway Co. It is not possible to plot this record because the exact horizon of the mouth of the well is not known. The well was begun, however, somewhere near the top of the Pierre shale and continued to a depth of 2,710 feet, which would bring it near the base of the Colorado shale.

Upper Cretaceous time seems to have been ushered in by a widespread transgression of the sea extending westward beyond the eastern front of the present Rocky Mountains. During the Colorado epoch great quantities of mud and silt were spread out over the floor of this epicontinental sea, and its waters teemed with life, the remains of which were in part entombed in the accumulating muds that now constitute the Colorado shale. The fine texture and homogeneous character of this shale and its freedom from notable amounts of sandy material, except perhaps near its base, indicate that it was laid down under very uniform conditions. This implies that the relative elevations of land and sea must have remained nearly constant throughout the Colorado epoch. So the sea was filled to a depth of more than 2,300 feet by the accumulated mud and as the land surface was necessarily lowered by the removal of this material, it seems necessary to infer that the relations between land and sea level could not have remained constant unless the sea floor was being gradually depressed at about the same rate as that at which the sediments accumulated.

This gradual submergence was arrested and the Colorado epoch was brought to a close in the western part of the epicontinental sea by an uplift of the western land mass. As a result 
of this uplift the sea became shallow and th probably withdrew from local areas, and the accelerated streams brought down great quantities of sand, which were spread over the shallow sea floor and now constitute the Eagle sandstone. As the uplift progressed the sea withlrew from its former western shore to a point, in the latitude represented by the cliasrammatic section on Plate $I V$, a few miles east of section $\Lambda$, for from that place westward the upper part of the Eagle sandstone contains thin beds of carbonaceous shale and lignite. The distance seaward to which this uplift was effective in producing a change of sedimentation is 2 or 3 miles east of section B, Plate IV, or about the present site of Musselshell River in the western part of the area here discussed. It that place the Eagle sandstone feathers out between the Colorado and Claggett formations and thence eastward the deposition of shale was continuous through the Colorado, Eagle, and Claggett epochs.

Inother submergence in the Claggett epoch restored the sea orer at least a part of the area from which it had been withdrawn, and the deposition of shale was extended westward, corering the Eagle sandstone in this part of Montana. This submergence did not extend as far northwest, however, as that of the Colorado epoch, because, as shown by Stebinger, ${ }^{1}$ the entire interval between the Colorado and Bearpaw epochs in the vicinity of the front range of the Rocky Mountains was characterized by the deposition of sediments that were mainly of continental origin.

After 500 to 700 feet of marine shale had been laid down another emergence set in which marked the begimning of the Judith River epoch. This emergence was more widespread than that of the preceding Eagle epoch, and during its progress the sea was withdrawn from the area herein considered to about the longitude of $107^{\circ} 30^{\prime}$ - that is, to some position between the points indicated by $\mathrm{D}$ and $\mathrm{E}$ in the diagrammatic section on Plate IV. The clay and sand not transported by the streams from the adjacent highlands were in part spread out as continental deposits on the emerged sea floor and in part carried out to the sea and deposited beneath its surface. Testward from point $B$ the resulting samrstones and shales of

1 Stebinger, Eugene, The llontana group of northwestern Montana: I. S. Geol. Survey Prof. Paper 90, Pp. 62-63, 1914. the .Juclith River formation contain the remains of land and fresh-water vertebrates and invertebrates, leares, stems, trunks of trees, and beds of lignite; whereas east of point E these deposits contain the remains of marine organisms.

How far eastward this . Judith River uplift was effective is not known. Sections 1 to $G$ in Plate IV show that the formation gradually thins from west to east, and apparently it either disappears or is represented by not more than 15 feet of sandstone at point $\mathrm{H}$, in the longitude of Glendive. The well drilled by the Northern Pacific Railway Co. in sec. 20, T. 14 N., R. 55 E., about 10 miles southwest of Glendice, was begun near the top of the Picrre shale and penetrated a bed of sandstone 15 feet thick at a depth of 745 feet and another bed 6 feet thick at a depth of 900 feet. The remainder of the well $\log$ is giren as shale down to a depth of 2,710 feet, or near the base of the Colorado. It is evident, therefore, that in the longitude of Glendive conditions of sedimentation were practically uniform thronghout Colorado and Montana time and that the oscillations which gave rise to the Eagle and Judith River deposits to the west dirl not extend that far east.

A renewed submergence brought the Judith River epoch to a close and restored the sea orer the entire known area of the Juclith River formation. During this, the last widespread submergence, 1,000 feet or more of marine shale was laid down, constituting the Bearpaw formation. This submergence was followed by a widespread emergence that resulted in the withdrawal of the sea from this part of the continent, which has since remained abore sea lerel except in small areas. This uplift was probably of epeirogenic character, because the next succeeding deposits seem to have suffered the same amount of orogenic deformation as the underlying Bearpaw shale.

On the lowlands produced during this uplift the continental sediments and associated coal bets of the Lance and Fort Union were laio down apparently without interruption and under only such changes in conditions as resulted in the alternate deposition of sand and mud and the more or less extensive accumulation of regetable growth. This period of deposition was brought to a close by a widespread orogenic disturbance, accompanied by folding 
and thrusting, which produced the principal ar tectonic features of the Rocky Mountain system. Since that time erosion has reduced the land surface to its present form, though it may be that between the epochs of deformation and erosion the Oligocene and Miocene deposits now found farther east were deposited over parts of this region as well.

By way of summary it may be said that eastern Montana remained beneath the sea and was not affected by any oscillations of land and sea level throughout the Colorado and Montana epochs, whereas in the central part of the State, at least as far west as the front of the present Rocky Mountains, there were oscillations of land and sea level produced either by rhythmic gentle depressions of the sea floor or by uplifts of the land mass to the west. The first of these uplifts, which resulted in the deposition of the Eagle sandstone, was of the shortest duration and was effective in the area here described for only a few miles east of its western boundary. The uplift during the Judith River epoch was of longer duration, to judge by the thickness of material deposited, and was considerably more widespread. As a result of this uplift the sea withdrew to about the longitude of $107^{\circ} 30^{\prime}$ and the site of sedimentation was shifted to some point east of the longitude of Forsyth, perhaps nearly as far east as Glendive. Because of this change the Montana group is in the central part of the State divisible into the Eagle, Claggett, Judith River, and Bearpaw formations but farther east consists of a single lithologic unit-the Pierre shale-to which a thin representative of the Fox Hills sandstone is added near the eastern boundary. In this eastern region also there is little if any lithologic distinction between the shales of the Colorado and Montana epochs. 


\title{
PLIOCENE AND PLEISTOCENE FOSSILS FROM THE ARCTIC COAST OF ALASKA AND THE AURIFEROUS BEACHES OF NOME, NORTON SOUND, ALASKA.
}

\author{
By William Healey Dall.
}

\section{INTRODUCTION.}

Exploration of the geology of the Arctic and subarctic shores of Alaska began as early as the voyages of Kotzebue and Beechey, in 1816 and 1826, and a detailed report on the vertebrate fossils found there, with a wealth of illustration, was made by Sir John Richardson in 1854, in the "Zoology of the voyage of the Herald." Nothing of importance bearing on the Tertiary invertebrates of this region appears in the literature of the-nineteenth century, and but little on those of the older formations. A search of the marine sandstone strata on the right bank of the Yukon near Nulato, made by me in 1867 and 1868, disclosed only a few traces of fossils belonging to the genus Mytilus and led to the supposition that the age of the deposit might be Tertiary, but later investigations place it in the Mesozoic. While I was in the Coast Survey service in 1880 the Pleistocene deposits in Kotzebue Sound and near Bering Strait previously referred to by Chamisso, Beechey, and Richardson were examined; ${ }^{1}$ and numerous vertebrate remains were collected; but, with the exception of a species of Pisidium, no invertebrates were found.

With the explorations of F. C. Schrader and W. J. Peters, of the United States Geological Survey, in $1901^{2}$ the first really systematic geologic reconnaissance of the Arctic coast of Alaska was begun. They described the stratification of the coastal deposits and collected marine invertebrate fossils from them, part of which were submitted to me and determined to be of Pliocene age. A brief summary of the species was prepared for the above-cited report.

When gold was discovered in the beach sands of the north coast of Norton Sound, near Nome,

\footnotetext{
1 Am. Jour. Sei., 3d ser., vol. 21, pp. 104-111, 1881.
}

2 U. S. Geol. Survey Prof. Paper 20, 1904. in 1898 , attention was attracted to this part of Alaska, and the Geological Survey, represented by A. H. Brooks and F. C. Schrader, began geologic work in the following year, but it was not until 1905 that any invertebrate fossils were received from the region; in that year a small lot of nine species received by F. H. Moffit, from Mr. J. J. V. Beaver, of Nome, were submitted to me, and later a report on them was published in the American Journal of Science. ${ }^{3}$ The interest attaching to these fossils was so great that the members of the Survey working in the region were urged to make special exertions to obtain a larger series.

In 1908 E. M. Kindle, P. S. Smith, and R. D. Mesler succeeded in obtaining a considerable number of specimens from various localities in the vicinity of Nome, of which I prepared a preliminary lisi. ${ }^{4}$

In the summers of 1912 and 1914 collections were made on the Arctic coast of Alaska at Peard Bay, about 30 miles southwest of Point Barrow, and at Carter Creek, Camden Bay, about 1 mile from the coast, by $\mathrm{E}$. de K. Leffingwell. A small series of specimens submitted by Leffingwell to the United States Geological Survey was determined by me and considered, to belong to a stratum of the same Pliocene age as those obtained farther east on the Arctic coast by Schrader and Peters.

GEOLOGY. COLVILLE "SERIES."

The portion of the Colville "series" referred to the later 'Tertiary' is thus described by Schrader: ${ }^{5}$

This portion of the section is practically free from indurated rock. It consists of nearly horizontally stratified beds of fine gray, slate-colored, or ash-colored calcareous

${ }^{3}$ Am. Jour. Sci., 4th ser., vol. 23, p. 457, 1907.

1 Moffit, F. H., Geology of the Nome and Grand Central quadrangles, Alaska: U. S. Geol. Survey Bull. 533, pp. 45-46, 1913.

6 U. S. Geol. Survey Prof. Paper 20, pl. 83, pl. 14, A, 1904. 
silts, containing faunal remains. It is tentatively referred to the Pliocene on the basis of fossils collected in place by the writer in the bluff (near its top) on the west side of the Colville alout a mile north of the seventieth parallel.

The section assigned to the Pliocene horizon at Carter Creek, 1 mile from the coast of Camden Bay, on the Aretic shore of Alaska, was measured by Leffingwell as follows:

$$
\text { Section at Carter Creck. }
$$

Top.

1. Sand with intermixed humus................ 30

B. Sand without fossils, some gravel........... 80

(. Pale-gray sand with marine fossils ........... 100

The fossils appear from the collections to be most abundant in the lower 100 foet of the section.

\section{GUBIK SAND.}

Sehrader ${ }^{1}$ describes the supposed Pleistocene deposit of the Colville River region as follows:

Besides the Tertiary Colville series, which underlies the coastal plain along Colville River, the section here comprises deposits supposed to be Pleistocene. Of these, probably the most important and interesting is a surficial deposit of brownish sand or loam about 10 to 15 feet in thickness, which unconformably overlies the beds of the Colville series, apparently as a continuous mantle. * * * The deposit consists of fine sand, with apparently an admixture of considerable silt. In some localities it seems to be more sandy toward the base and more earthy toward the top, where it terminates in from one to several feet of dark-brown or black humus, clothed at the surface with moss and a little grass. It is ordinarily free from gravel, but in several instances subangular cherty pebbles, ranging from mere sand grains to fragments as large as onefourth inch in diameter, were found. These occur very scatteringly and are sometimes roughened, as if wind worn. In some localities a fine gravel seems to intervene between the base of the deposit and the underlying Tertiary beds, as if representing the basal part of the deposit. The deposit as a rule is structureless, or without stratification planes. Owing to this fact, together with its surficial and widespread occurrence and the homogeneity of its materials, for want of a better term in field work it was called loess, but in the fear that this term may be undesirable, it is here named the Gubik sand, after the Eskimo name of Colville River.

In a low bluff on the coast 15 miles southwest of Point Barrow settlement and in the talus from this bluff Leffingwell found five species of invertebrate fossils, all belonging to recent species. This deposit is probably Pleistocene and may be tentatively correlated with the Gubik sand of Schrader, which oceupies a similar position in the section farther east.

1 Op. cit., p. 93.
NOME ELEVATED BEACHES.

On the south side of Sewarl Peninsula (originally given the native name Kaviiak), on the north shore of Norton Sound, the gold prospectors have revealed the presence of a series of ancient beaches the gravels of which contain numerous marine fossils, including a considerable proportion of extinet speeies leading to their identification as of Pliocene age. In referring the horizon containing the numerous extinct species to a pre-Pleistocene age my conclusions rest entirely upon the paleontologic evidence. ${ }^{2}$ It is proper to state that P.S. Smith and A. H. Brooks, of the Geological Survey, from physiographic observations, are disposed to assign a Pleistocene age to the beaches. In regard to the succession of the strata there is no difference of opinion.

The present beach near Nome may be considered the "first beach." The "second beach" lies inland, at an irregular distance that varies with the topography but is everywhere less than a mile, and has an elevation above sea level of 37 feet. The "third beach," some $2 \frac{1}{2}$ to $3 \frac{1}{2}$ miles inland, has been elevated to the height of 79 feet above the sea. ${ }^{3}$ Between the second and third beaches are several less well-defined intermediate beaches, one of which is 22 feet abore sea level, thus being lower than the second beach, to the south of it. Between the second beach and the present beach shafts have been sunk to a depth of 65 to 70 feet which reach at about 20 feet below the present sea level the oldest beach of all those now known, which has locally received the name submarine beach or beaches. These beaches have been described in detail by Moffit in the bulletin cited. Doubtless still others remain to be discovered.

\section{INDICATIONS OF ELEVATION AND CLIMATE.}

The indications of the Tertiary geology of the northern and northeastern shores of Alaska are therefore, in substance, that from early Pliocene (if not eren older) time the land underwent a general elevation, broken by periods of rest sufficient to allow the formation of low scarps with their attendant beaches, and at least one unimportant depression during the earlier portion of the period. The massive granite extrusions, such as form Cape Prince

2 Of 62 species 23 , or 37 per cent, are extinct.

s Moffit, F, II., U. S. Geol. Survey Bull. 533, p. 41, fig. 9, p. 7s, 1913. 
of Wales, the Diomede Islands of the Bering Strait, and a considerable portion of the Asiatic coast on the west side of the strait, though probably not all of one age, are almost certainly all older than the period during which these beaches were in process of formation.

The presence of widely distributed Eocene or Oligocene leaf beds and lignitic coals, covered in some localities by beds of sandstone containing marine Miocene fossils, shows that a milder climate in earlier Tertiary time, allowing a profuse growth of oaks, planes, figs, and other trees, was succeeded during the Miocene by a depression of much of the land below the sea level with a much colder climate and considerable volcanic activity. This was followed by a moderate amount of elevation, which has been practically continuous to the present time. During the Pliocene the climate seems to have moderated, judging by the character of the marine fauna, to be later subjected to the Arctic temperatures which came in with the glacial epoch and still persist.

\section{ROUTES OF MIGRATION OF FAUNA.}

The bearing of these conditions upon the theories relating to the immigration of Asiatic land animals into America is important. A superficial glance at an ordinary map is likely to lead the observer who goes no deeper into the subject to the conclusion that land bridges, including the Bering Strait region and the Aleutian Island chain, may reasonably be assumed as the routes by which Asiatic immigrations took place.

I have elsewhere ${ }^{1}$ pointed out the serious objections to these assumptions that arise from a more thorough knowledge of the geology. So far as the Aleutian route is concerned it must be positively rejected as impracticable. The Bering Strait region offers more plausibility, yet the evidence so far gathered from geologic exploration indicates not only that no closer land connection than at present has existed between the two continents at Bering Strait since Miocene time but, on the contrary, that the present separation is less than at any period during that time. The conclusion from our present knowledge is inevitable either that the postulated land bridges must have existed in some other

1 Am. Anthropologist, vol. 14, pp. 12-18, 1912. locality or that the assumed migration must have taken place over the ice of the strait when frozen, possibly during the glacial epoch.

\section{INTERCOMMUNICATION OF ATLANTIC AND PACIFIC FAUNAS IN PLIOCENE TIME.}

Still another important conclusion is indicated by a study of the characteristics of the Pliocene marine invertebrate fauna. I have already stated that the fauna indicates a more temperate sea than at present washes those shores. Taken in connection with other data derived from a study of the North Atlantic Pliocene deposits in England, Iceland, and on the New England coast, the present investigation shows that a more free connection probably existed in Pliocene time between the North Atlantic and the Bering Sea regions. This is indicated by the presence in North Atlantic Pliocene beds, as fossils, of species still living in Bering Sea, and conversely by the presence in the North Atlantic recent fauna of species belonging to groups now extinct on the Pacific side in the Pliocene at Nome. F. W. Iarmer, ${ }^{2}$ who is at present revising the fauna of the Crag of England and Iceland, has already found genera and species now extinct in the North Atlantic region but living in Bering Sea. It is probable that on the completion of his monograph a still larger number will be noted.

In an investigation of the fossils of the marl at Sankaty Head, Nantucket, the lower horizon of which is probably upper Pliocene, J. Howard Wilson, ${ }^{3}$ in 1904, found several Bering Sea species now extinct in the Atlantic region. The presence of Corbicula in a small Pliocene lens discovered by Woodworth above the Miocene beds of Gay Head, Marthas Vineyard, is proof that on the Atlantic, as on the Pacific coast, the Pliocene was an epoch in which the temperature of the sea in that region was higher than in the preceding and subsequent epochs. The presence of Rangia in the fossil fauna of Cornfield Harbor, Chesapeake Bay, is confirmatory evidence to the same effect.

There is also evidence of a southward extension of the cooler-water fauna of the Californian

2 Pliocene Mfollusca of Great Britain, Paleontographical Society, 1913, pl. 1, 1914; pt. 2, 1916.

3 The Pleistocene formations of Sankaty Head, Nantucket: Jour, Geology, vol. 13. pp. 713-734, 1905. 
Pleistocene on the Pacifie coast as far as the island of Socorro, which will he presented in a future publication.

\section{LISTS OF SPECIES.}

The species collected at each locality on the Alaskan coast above indicated will now be enumerated. 'The collectors' station numbers are given when such numbers appear on their labels. The large numbers are those of the stations as registered in the official records of the United States Geologieal Survey.

Otter Creek, 2 miles from the coast near Nome, 50 feet below the surface and at an elevation above the present sea level of about 20 feet. Collected by J. J. T. Beaver, 1905. Those marked with an asterisk now live south of the line of floating ice in winter, or, roughly, in about the latitude of the Aleutian Islands. Pliocene.

Pecten islandicus Müller.

Pecten lioicus Dall (temperate type). Extinct.

Pecten kindlei Dall (temperate type). Extinrt.

* Monia macroschisma Ieshayes.

Cardium sp. (fragment).

Venericardia crassidens Broderip and Sowerby.

Venericardia crebricostata Krause.

Macoma sabulosa Spengler.

* Panomya ampla Dall.

Hemithyris psittacea Gmelin var. alaskana Ioll

Balanus sp. (fragments).

Station $18 a(5074)$. Second beach, about $1 \frac{1}{2}$ miles north of Nome, at Center Creek, 32 feet below the surface and about 20 feet above the present level of the sea. Collecterl by E. M. Kindle, 1s99. Pliocene.

* Pecten kindlei Dall.

* Ionia macroschisma Deshayes.

Mytilus edulis Linné.

Venericardia crebricostata Krause.

* Astarte rollandi Bernardi.

Istarte arctica Gray.

Istarte actis Dall.

('ardium ciliatum Fabricius.

Macoma middendorffii Dall.

Macoma incongrua Martens.

Macoma sabulosa Spengler.

* Siliqua cf. S. patula Dixon.

Spisula polynyma var. alaskana I)all.

* Mya sp. (aff. M. japonica Jay).

Saxicava arctica Iinmé.

* Panomya ampla Dall.

Panomya arctica rar. turgida Irall.

Chrysodomus mesleri Dall.

Chrysodomus (fragment).

Thais (Nucella) nomeana Dall.

Trichotropis insignis Middendorff.

Natica sp.

Natica aff. N. clausa Broderip and Sowerby.

Cryptoctenidia magua I ball.

* Balanus rostratus (Hoek) alaskens is Pilslory.

* Balanus evermanni Pilsbry.
Station $21 a(5075)$. Five miles east of Nome, from the second beach. Collected ly E. M. Kindle, $190 x$. Pliocene.

* Magasella aleutica Dall.

I Iemithyris psittacea Gmelin var. alaskana Dall.

Station $21 b(5076)$. Five miles east of Nome, from prospect holes in second beach. Collected by E. M. Kindle and R. D. Mesler, 1908. Older Pliocene.

Pecten islandicus Müller.

Chrysodomus sp. (fragment).

Thais (Nucella) nomeana Dall.

Hemithyris psittacea Gmelin var. alaskana Dall.

* Magasella alentica Dall.

*Balanus rostratus alaskensis Pilsbry.

Station $22 a$ (5077). One and one-half miles east of Nome, fron prospect holes in second beach. Collected by E. M. Kindle and R. D. Mesler, 1908. Pliocene.

Pecten islandicus Müller.

* Ilonia macroschisma Deshayes.

Mytilus edulis Linné.

Cardium (Serripes) grönlandicum Cimeliu.

Cardium ciliatum Falricius.

Astarte sp. (fragment).

Venericardia crassidens Broderip and Sowerby.

Nacoma middendorffii Dall.

Macoma incongrua Martens.

Saxicava arctica Linné.

* Mya sp. (aff. M. japonica Jay).

* Panomya ampla Dall.

Buccinum sp. (fragment).

Trichotropis insignis Middendorff.

Ilemithyris psittacea Gmelin var. alaskana Dall.

* Balanus rostratus alaskensis Pilsbry.

Station $22 b$ (5078). One-fourth to one-half mile east of Nome, on the second beach, in prospect holes. Collected by E. M. Kindle and R. D. Mesler, 1908. Pliocene.

* Ionia macroschisma Deshayes.

Cardium ciliatum Fabricius.

Astarte actis Dall.

Macoma incongrua Martens.

Macoma middendorffii Dall.

Saxicava arctica Linné.

*Panomya ampla Dall.

Spisula polynyma Stimpson var. alaskana Dall.

Thais (Nucella) nomeana Dall.

* Littorina palliata Say.

Littorina sp. (aff. L. grandis Middendorff).

Cryptoctenidia magna Dall.

*Balanus balanoides (Linné) Pilsbry.

* Balanus rostratus alaskensis Pilsbry.

Station 627. Forty miles up Colville River from its mouth on the Arctic coast. Collected by F. C. Schrader, 1901. Pliocene.

Chrysodomus leffingwelli Dall

Pyrulofusus schraderi Dall.

Station 7067. Peard Bay, about 30 miles southwest of

Point Barrow, from top of high bank. Collected by

E. de K. Leffingwell, 1914. Pleistocene(?).

Astarte bennetti Dall.

Astarte borealis Schumacher.

Astarte leffingwelli Dall.

Tenericardia crebricostata Krause. 
Station 1 (7068). Carter Creek, 1 mile from the Arctic coast at Camden Bay, in fine consolidated silt from top to 30 feet below. Collected by E. de K. Leffingwell, 1914. Pliocene.

* Nucula mirabilis A. Adams (Japan).

Astarte actis Dall (fragment).

Venericardia crebricostata Krause.

Saxicava arctica Linné.

Lora sp.? (fragment).

*Antiplanes sp.? (fragment).

Buccinum sp. (fragment).

*Balanus crenatus (Bruguière) Pilsbry.

Station B (7069). Carter Creek, 100 yards east of station A (7068) and 80 feet below it. Collected by E. de K. Leffingwell, 1914. Pliocene.

Astarte carteriana Dall.

* Antiplanes sp.? ef. A. purpurea Dall.

Station C (7070). Carter Creek, 200 yards east of station B (7069) and 100 feet below it. Collected by E. de K. Leffingwell, 1914. Pliocene.

Leda sp. (cf, L, arctica Loven).

Leda sp. (cf. L. frigida Torell).

Astarte sp. (fragment).

Cyrtodaria camdenensis Dall.

*Cadulus arcticus Dall.

Dentalium sp. (fragment).

*Philine sp. (fragment).

Turris (Antiplanes?) sp. (fragment).

Cryptonatica sp. (aff. C. clausa Broderip and Sowerby).

Amauropsis sp. (cf. A. islandicus Gmelin).

*Caecum sp. (fragment).

Station 7228. Fifteen miles southwest of Barrow village, Point Barrow, Alaska, from talus below bluff on the coast. Collected by E. de K. Leffingwell, 1910-12. Pliocene.

Macoma sabulosa Spengler.

Astarte actis Dall.

Astarte leffingwelli Dall.

Venericardia crebricostata Krause.

Balanus rostratus alaskensis Pilsbry.

Station 7229. Specimens in place at same locality as station 7228, taken from the bluff. Pliocene (?).

Astarte sp. (fragment).

Venericardia crebricostata Krause.

Chrysodomus fornicatus Gray.

Station 200a (7230). Camden Bay, Arctic coast, at Carter Creek. Collected by E. de K. Leffingwell, 1912. Pliocene.

Astarte martini Dall.

Astarte sp.

Venericardia nuwokensis Dall.

Buccinum sp. (fragment).

Station $200 b$ (7231). Same locality as station 7230. Col-

Iected by $\mathbf{E}$. de K. Leffingwell, 1912. 'Pliocene.

Musculus sp. (fragment).

Serripes grönlandicus Gmelin.

Astarte arctica Gray.

Astarte martini Dall.

Cyrtodaria camdenensis Dall.

Colus sp. (fragment).

Balanus sp. (fragment).

Balanus balanoides (Linné) Pilsbry.

$131049^{\circ}-20-3$
Station $19 a(7618)$. One mile north of Fort Davis, east of Nome, Alaska, near parting of Florence and Otter Creek gulches (Gallatin mine). Collected by R. D. Mesler, 1908. Pliocene.

Pecten islandicus Müller.

* Monia macroschisma Deshayes.

Cardium ciliatum Fabricius.

Venericardia crebricostata Krause.

Venericrrdia crassidens Broderip and Sowerby.

Astarte actis Dall.

Macoma incongrua Martens.

* Macoma brota var. lipara Dall.

Macoma balthica Linné

Spisula polynyma Stimpson var. alaskana Dall.

Saxicava arctica Linné

Panomya ampla Dall.

*Panomya arctica Lamarck var. turgida Dall.

Iemithyris psittacea Gmelin var. alaskana Dall.

Balanus sp. (fragment).

Station 18a (7619). Center Creek mines, 2 miles nortliwest of Nome, at second beach. Collected by E. M. Kindle and R. D. Mesler, 1908. Pliocene.

*Pecten kindlei Dall.

*Monia macroschisma Deshayes.

Cardium ciliatum Fabricius.

Astarte actis Dall.

Macoma middendorffii Dall.

Macoma balthica Linné.

Spisula polynyma Stimpson var. alaskana Dall.

Chrysodomus saturus Martyn.

Chrysodomus mesleri Dall.

Thais (Nucella) nomeana Dall.

Trichotropis insignis Middendorff.

*Natica sp. (aff. N. russa Gould).

Cryptoctenidia magna Dall.

Balanus sp. (fragment).

Station 20a (7260). Half a mile west of Nome, from tailings of Welsh mine on second beach. Collected by E. M. Kindle and R. D. Mesler, 1908. Pleistocene.

Astarte fabula Reeve.

Saxicava arctica Linné.

Station $20 b$ (7621). Half a mile west of Nome, from prospect holes on the tundra near Snake River, second beach. Collected by E. M. Kindle and R. D. Mesler, 1908. Pliocene.

Mytilus edulis Linné.

Cardium ciliatum Fabricius.

Astarte sp. (fragment).

Venericardia crassidens Broderip and Sowerby.

Macoma balthica Linné.

Macoma middendorffii Dall (fragment).

Chrysodomus sp. (fragment).

Thais (Nucella) nomeana Dall.

Balanus sp. (fragment).

Station 2 (7622). Half a mile northwest of Nome, from gravel 10 feet below the surface, near submarine beach, in prospect holes. Collected by E. M. Kindle and P. S. Smith, 1908. Pliocene (?).

Mytilus edulis Linné.

* Monia macroschisma Deshayes.

Cardium ciliatum Fabricius.

Venericardia crassidens Broderip and Sowerby.

Macoma incongrua Martens.

Macoma middendorffii Dall.

Thais (Nucella) nomeana Dall.

Balanus sp. (tragment). 
Station 1 (7623). Wine on submarine beach 30 feet below present sea level, half a mile northwest of Nome. Collected by E. M. Kindle and P. S.Smith, 1908. Pliocene. Cardium ciliatum Fabricius.

Venericardia crassicostata Krause.

Astarte hemicymata Dall.

* Astarte (Gonilia?) diversa Dall.

Nacoma balthica Liuné.

* Mya sp. (aff. Mr. japonica Jay).

Chrysodomus sp. (fragment).

Balanus sp. (fragment).

Station 3 (7624). Prospect hole half a mile northwest of

Nome, on submarine beach. Collected by E. M.

Kindle, 1908. Pleistocene (?).

Astarte fabula Reeve.

Station 7477. Dump of shaft 80 feet deep on the tundra

between Dry and Bourbon creeks 1 mile from beach at

Nome. Collected by F. L. Hess, 1905. Pliocene.

Admete sp.? (fragment).

Chrysodomus sp. (iragment).

*Tachyrhynchus lacteola Carpenter.

*Pecten (Chlamys) n. sp. (fragment). Southern type.

Pecten (Chlamys) islandicus Müller.

Astarte sp. (fragment).

Astarte hemicymata Dall.

* Astarte diversa Dall.

Astarte arctica Gray.

Serripes grönlandicus Gmelin.

Cardium ciliatum Fabricius.

Venericardia paucicostata Krause.

Jiacoma calcarea Gmelin.

* IIya (n. sp.?) (iragment)

Saxicava arctica Linné.

Balanus rostratus alaskanus Pilsbry.

Myriozoum "truncatum Pallas" (n. sp.?).

\section{DESCRIPTIONS OF NEW SPECIES. GASTROPODA.}

Antiplanes? ef. A. purpurea Dall.

A decorticated specimen of about six whorls presents the appearance of an Antiplanes of the type of $A$. purpurea Dall. It is in a state too dilapidated to serve as the basis of a description but is worthy of mention as an indication of the probable presence of this genus in the fauna.

Station 7069, in the Pliocene, horizon B, s0 feet below horizon $A$, and about 300 feet east of station 7068. U. S. Nat. Mus. catalogue No. 324316. It is about a mile from the Arctic coast in the Camden Bay region; the matrix appears to be a hardly consolidated ash. There is a possibility that the specimen may represent a broken and decorticated Colus.

Chrysodomus mesleri Dall, n. sp.

Plate $\mathrm{V}$, figures 2,3 .

$\triangle$ fragment only of this species was obtained, but its characteristies are so pronounced that it can not fail to be recognized when better specimens are found. The shell had more than four whorls, with a smooth surface and an appressed suture strongly undulated by the riblbing; the penultimate whorl has seven extremely strong protractively angular axial ribs, projecting as stout knobs at the shoulder, which are connected by an obscure spiral ridge; the interspaces are deep and about as wide as the ribs; on the upper whorls the series of knobs develop into a continuous broad undulating spiral ridge and the ribs disappear; the last whorl is deficient, but the remaining portion indicates that it was ribbed, at any rate near the suture. Ileight of the penultimate whorl, 25 millimeters; diameter, 36 millimeters.

Station $7619(18 a)$. Pliocene. From the Center Creek mines, 2 miles north of Nome. Collected by E. M. Kindle and R. D. Mesler, 1908. U. S. Nat. Mus. catalogue No. 324317.

The species perhaps nearest allied to this, though sufficiently distinct, is $C$. saturus Martyn, of the Recent fauna of Bering Sea.

A fragment (fig. 3) from station 5074 (18a) at Center Creek, $1 \frac{1}{2}$ miles north of Nome, from the second beach, is probably of the same species and indieates that the ribs reached over the last whorl clear to the beginning of the twisted and recurved canal.

Chrysodomus leffingwelli Dall, n. sp.

Plate $\mathrm{V}$, figure 11.

Shell of moderate size, with more than four rounded whorls (apex decollate) separated by a distinct, deep, but not channeled suture; whorls widest at the shoulder; spiral sculpture of (between the sutures three, on the last whorl about 14) strong, somewhat flattened cords regularly spaced and separated by wider channeled interspaecs in which run from one to three minor cords which, toward the canal, may be absent; axial sculpture of (on the last whorl eight or nine) rather narrow, not very prominent sigmoid ribs extending from the suture over the body and becoming obsolete on the base; these ribs are less distinet on the spire, and the surface also bears fine, close-set incremental lines; pillar twisted, inner lip slightly erased; canal moderately long with a very feeble siphonal fasciole, slightly recurved; outer lip defective in the specimen. Height of (decollate) three whorls, 74 millimeters; 
diameter at shoulder, 40 millimeters; height of last whorl, 60 millimeters; of aperture, 40 millimeters.

Station 627, 40 miles up Colville River from the Arctic coast, with Pyrulofusus schraderi. Pliocene. Collected by F. C. Schrader, 1901. U. S. Nat. Mus. catalogue No. 210853.

This species belongs to the general group represented by $C$. lyrata Martyn but does not agree closely with any of the known recent forms. Other specimens have the ribs more or less obsolete.

\section{Pyrulofusus schraderi Dall, n. sp.}

Plate $V$, figures 10,13 .

Shell large, solid, dextral, with a short spire and expanded last whorl; whorls about five, rapidly increasing; nucleus large, swollen, of about two whorls (decorticated in the specimen); subsequent whorls sculptured all over with extremely fine, close-set spiral threads; axial sculpture of inconspicuous incremental lines and on each whorl five very prominent rounded sigmoid ribs diminishing toward the base and stronger at the shoulder, below which they are very obliquely inclined forward; the interspaces are much wider than the ribs; the suture is deep but hardly channeled; the whorl rises a little at the posterior corner of the aperture and on the inner lip is a thin layer of enamel. The base and aperture of the unique specimen are deficient. Diameter of specimen at aperture from the inner lip, about 50 millimeters; estimated original length, about 75 millimeters.

Phocene at station 627, 40 miles up Colville River from its mouth at the Arctic coast, in silt beds 80 feet above the river, 5 to 15 feet below the base of loess, 20 feet below the surface of the soil. Collected by F. C. Schrader. U. S. Nat. Mus. catalogue No. 210854.

Thais (Nucella) nomeana.Dall, n. sp.

Plate $V$, figure 9.

This form is represented only by worn and more or less defective specimens which resemble the form from the Pliocene of Coos Bay, Oreg., described by the writer.

It is certainly a precursor of $N$. lamellosa Gmelin and would probably by casual observers be referred to as a variety of that species. The shell is nearly smooth, only ob- solete traces of spiral sculpture being apparent. The general aspect is rude, the suture closely appressed. None of the specimens show any denticulation on the inside of the outer lip; there is a strong siphonal fasciole and a very narrow chink between the fasciole and the pillar, which is thick and callous, though there are no indications of a thickening of the inner lip. In size and general characteristics this form closely approaches $N$. Zamellosa.

Station 5074, Pliocene on Center Creek, about $1 \frac{1}{2}$ miles north of Nome, from the second beach. Collected by E. M. Kindle. U. S. Nat. Mus. catalogue No. 324318.

Littorina palliata Say.

Plate $\mathrm{V}$, figure 12.

Shell small, smooth, solid, turbinate, of about four rounded whorls; suture distinct, appressed; surface with hardly visible incremental lines; the rotundity of the whorls slightly compressed in front of the suture; aperture rounded, slightly angulate at the posterior commissure; outer lip thick, not reflected, entire; body and umbilical region with a thin flattened layer of callus which merges evenly into the basal lip; base convexly rounded. Height, 12 millimeters; diameter, 12.5 millimeters; last whorl, 10 millimeter's in height.

Station $5078(22 b)$. Pliocene. From prospector's pits on the second beach, one-half to one-fourth mile east of Nome. Collected by E. M. Kindle and R. D. Mesler, 1908. U. S. Nat. Mus. eatalogue No. 324319.

This species is of the type of Littorina palliata Say, of which no living form now inhabits the Pacific Ocean or any part of the Arctic coast west of Mackenzie River and east of the Lena. The specimen retains some of the yellowish coloration characteristic of the Atlantic form, and after a scrutinizing comparison with specimens of Littorina palliata from Rhode Island and with all the varieties of obtusata from Europe, no characters have been discovered by which the Nome fossil can be distinguished from Littorina pal liata. This is natural enough, as obtusata. has never been found in America, whereas palliata is excessively common on the New England coast in localities where it has not been supplanted by the introduced Littorina litorea. 
The differences of size, form, and grographic distribution seem to be conclusive as to the specific distinetion between Littorina obtusata and Littorina palliata. They are not Aretie shells.

Cryproctenidia magna Dall, n. sp.

I'late $\mathrm{V}$, figure 1.

Shell large for the genus, ovate, apex very anterior, the lack behind it roundly arehed, the anterior slope more steeply descending; the apex blunt, usually eroded; seulpture of fine radiating threads with subequal interspaces, more or less cut into segments by incised lines corresponding to resting stages and equally distributed over the shell; interior white, the margins entire, smooth; the museular impression narrow, connected in front of the head by a linear sear indicating the attachment of the mantle. Height, 10 millimeters; length, 29 millimeters; breadth, 25 millimeters; apex behind the anterior margin, 5 millimeters. $\Lambda$ defective specimen measures 34 millimeters long and 29 millimeters wide.

Stations 5074, 5078, and 7619. Pliocene of Center Creek, $1 \frac{1}{2}$ miles north of Nome, from the "second beach," collected by E. M. Kindle. Also from prospect holes on the second beach, one-fourth to one-half mile east of Nome; and from Center Creek mines 2 miles northwest of Nome. Collected by E. M. Kindle and R. D. Mesler, 1908. U. S. Nat. Mus. catalogue No. 324320 .

The species of this genus are very similar to one another, but this is larger than any of the recent forms and differs in details of sculpture.

Cadulus arcticus Dall, n. sp.

P'late $T$, figure 8 .

Shell small, slender, areuate, smooth, with is circular section and no swelling ventrally; the color is white with narrow translucent zones irregularly disposed. Length, 7 millimeters; diameter at anterior end, 0.75 millimeter; height of are deseribed by the ventral curve, 1.2 millimeters.

Station 7070. Pliocene of Carter Creek, in the Camden Bay region of the Aretic coast, stratum C, 100 feet below stratum B and 600 feet east of station 7069, 1 mile from the coast. Collected by E. de K. Leffingwell, 1914. L'. S. Nat. Mus. catalogue No. 324322.
This stratum, from the collector's notes, seems to be some 220 feet below the uppermost stratum of the section.

\section{PELECYPODA.}

Pecten (Chlamys) kindlei Dall, n. sp.

Plate VI, figures 2, 7 .

Shell large, rather rude, belonging to the group of Pecten swifti Bernardi. Right valve with four broad, low radial ribs separated by much narrower, shallow, ill-defined interspatial furrows; the whole surface sculptured with strong radial, more or less paired flattish cords, of ten minutely medially grooved and sometimes separating into two distinet raclii; the interspaces are about as wide as the cords and distinetly chameled; they also retain patehes of a minute reticulated surface lamellation; the beak is pointed, the anterior ear large, aliform, with an acute but not deep notch, leaving a broad concentrically laminate fasciole, the margin of the disk at the noteh with a ctenolium of two or three rather widely separated short spinules; the radial threads crossed by rather coarse incremental lines; the posterior ear is very short, narrow, and oblique; inner surface of the valve smooth except near the distal margin, where it reflects the external sculpture; the adductor sear large, the resiliary pit rather small for the size of the shell, with the lateral margins raised; a narrow, transversely striated area exists, broader on the left valve; there are no auricular crura. Left valve with fice narrow radial ribs separated by wider shallow interspaces which are wider on the posterior half of the disk; the surface is covered with radial cords as in the other valve, but these are finer and closely crowded on the submargins; the reticular surface layer is the same as in the left valve, but the right valve as usual is more convex; anterior ear triangular, large, with about eight or ten radial cords; posterior ear narrow and short; both set off from the submargins of the disk by a deep, wide furrow; hinge line straight, with a flat area half as wide as the length of the pit. The young valves retain a reddish tinge in their substance. Height of adult valve, 92 millimeters; width of disk, 78 millimeters; of hinge line, 45 millimeters; diameter, 27 millimeters. Station 7619, Pliocene of Center Creek mines, 2 miles north of Nome, from the 
second beach. Collected by E. M. Kindle and R. D. Mesler, 1908. U. S. Nat. Mus. eatalogue No. 324301.

This species, from fragmentary remains collected by J. J. T. Beaver, of Nome, was identified by me in $1907,{ }^{1}$ with $P$. (C.) swifti Bernardi, of northern Japan. The present much more complete material, obtained the following year, enables me to correct this identification. The shell indeed much resembles the Japanese form, but it has not the concentric waves due to resting stages that appear in $P$. swifti, and the posterior ear is of quite different shape. The two bear to one another much such a relation as is found between Pecten nodosus of the Antilles and P. subnodosus of the Pacific coast of America.

Related to this species is the $P$. parmeleei Dall from the Pliocene of San Diego, Calif., with which fragments from a Pliocene deposit near Crescent City, Calif., were identified. The latter (figured by Arnold ${ }^{2}$ ) upon later and more exact study prove to be indistinguishable from the true $P$. swifti of Japan. The minute structure of the reticulated outer layer of $P$. parmeleei is quite distinct from that of $P$. swifti or the present species, but this delicate structure is so rarely preserved intact in the fossils that its help in specific discrimination is seldom available.

\section{Pecten (Chlamys) lioicus Dall.}

Pecten (Chlamys) lioicus Dall, Am. Jour. Sci., 4th ser., vol. 23, p. 457, fig. I, 1907.

From 50 feet below the surface in marine gravels near Nome, Norton Sound, Alaska, from a collection received by F. H. Moffit from Mr. J. J. V. Beaver, of Nome; donated to the U. S. Geological Survey. U. S. Nat. Mus. catalogue No. 110480. Pliocene.

No further specimens of this very distinct species have come to hand.

\section{Pecten (Chlamys) n. sp.}

In the material from the dump of an 80-foot shaft about a mile north of Nome (station 7477) were fragments of a Pecten undoubtedly distinct from any known northeastern Pacific species, but insufficiently complete to warrant naming. The ribs are high, with wider channeled inter-

1 Am. Jour. Sci., 4th ser., vol. 23, p. 457, 1907.

2 Arnold, Ralph, The Tertiary and Quaternary pectens of California:

U. S. Geol. Survey Prof. Paper 47, pl. 41, figs. 5, 5a, 1906. spaces. On the back of the ribs in the middle of the valve is a strong radial cord on each side of which is a smaller cord separated from the median one by a narrow groove. The more lateral ribs have a groove between two moderately strong cords, the inner cord of the medial ribs becoming obsolete. The ribs bear small low imbricating scales. In the interspaces the fine sculpture is minutely tessellate, the alternate scales sometimes raised, giving a minutely pustular effect. The medial ribs are about 3 millimeters and the interspaces about 4 millimeters wide. The submargins are feebly and more numerously threaded. The interior is smooth, grooved in harmony with the external sculpture. The shell probably reaches a length of some 3 inches when adult.

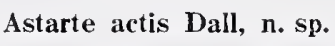

Shell of moderate size, rounded, very thick, nearly equilateral, beaks rather pointed, not conspicuous, usually more or less eroded; lunule lanceolate, narrow, elongate, shallow; ligamentary nymph strong, the nearly linear escutcheon extending beyond it 3 or 4 millimeters; outer surface rather rudely sculptured with coarse concentric incremental lines; hinge extremely heary, in the right valve a strong thick cardinal with deep pits on each side to receive the two narrower cardinals of the left valve, the posterior of which is more or less radially furrowed; there are traces of an obsolete anterior lateral in the left valve and of a receptacle for it in the right valve which vary in distinctness with the individual specimen; impressions of the adductors and mantle attachment are usually deep and distinct; the inner margins of the valves are entire. Height, 33 millimeters; length, 36 millimeters; diameter, 20 millimeters.

Station 5074 (18a). Pliocene on Center Creek, about half a mile north of Nome, from the second beach; collected by E. M. Kindle. U. S. Nat. Mus. catalogue No. 324302. Also station 7619 ( $1 \mathrm{~S} a)$, Center Creek mines, 2 miles northwest of Nome; collected by E. M. Kindle and R. D. Mesler, 190 s.

\section{Astarte carteriana Dall, n. sp.}

Plate VI, figures 1, 3.

Shell of moderate size, rather inflated, the general profile like Saxidomus giganteus on a small scale; surface sculptured with rather 
rude incremental lines; anterior end shorter, beaks rather pointed over a conspicuously depressed but not sharply limited lunular area; there is no escutcheon; a rather long nymph supported an external ligament under which in one specimen in the left valve is an exearated space having the aspect of the resilifer for a rather large internal resilium; in front of this is a single strong cartinal tooth with a wellmarked socket for a cardinal of the opposite valve; the hinge of the right ralve is deficient in the specimen, but under the lunule there is a rather well-marked lateral lamina; the posterior end of the shell is rather bluntly rounded, the base evenly areuate; the muscular sears are emphatically excarated, the inner valve margins smooth. Proportions taken from the incremental lines of a fractured specimen: Height, 16 millimeters; length, 25 millimeters; diameter, about 10 millimeters. The whole specimen when entire must have had a height of about 30 millimeters, and a length of more than 37 millimeters.

Station 7069. Pliocene of Carter Creek, stratum B, S0 fect below stratum A, and 100 yards east of station 7068. U. S. Nat. Mus. catalogue No. 324304 .

The specimens of this species consist of three fragments, only one showing the entire hinge. The excaration rescmbling a resiliary pit is probally the effect of erosion, in which case the shell would be allotted to the genus Astarte. At any rate the species can not be a typical Crassatellites, on account of the well-marked external ligament. Other specimens otherwise similar have the hinge of Astarte, though the teeth are more oblique and less triangular than in most of the Recent species.

\section{Astarte leffingwelli Dall, n. sp.}

Plate V1, figures 6,8 .

Shell of mokerate sizc, with high pointed prosococlous beaks curving over a decply' excarated, lanceolate lumule; anterior end shorter, dorsal margin concave, below evenly rounded; posterior dorsal margin nearly straight, descending, with a short ligamentary nymph and a narrow escutcheon nearly three times as long as the nymph; posterior end rounded, attenuater, base erenly arcuate, with a smooth inner margin; sculpture nearly smooth, uncler a lens with faint concentrie narrow undulations and very fine, even incremental lines; linge compressed, in the left valve with two thin and prominent cardinals and a long, little elcrated, but distinct posterior lateral lamina; muscular scars excarated. Height, 25 millimeters; length, 32 millimeters; diameter, 12.5 millimeters.

Station 7228. Pliocene. In talus below low bluff on the seacoast 15 miles southwest of Point Barrow; collected by E. de K. Leffingwell; U. S. Nat. Mus. catalogue No. 324305. Also station 7067 , about 30 miles southwest of Point Barrow at Peard Bay; probably Plcistocene; collectert by E. de K. Leffingwell.

\section{Astarte martini Dall, n. sp.}

Plate VI, figure 12.

Shell small, orate, with inconspicnous pointed beaks, dorsal slopes straight, anterior cnd rounded, shorter, base erenly arcuate, postcrior end slightly longer, attenuated and almost obliquely truncated; a narrow clongate escutcheon and shorter, narrower, slightly excarated lunule present; sculpture of somewhat irregular, slightly raised, elose set, concentric, narrow wavelets, becoming almost lamellose near the edge of the lumule; and in other specimens reduced to nan row threads on the disk; hinge heary, normal, muscular impressions somewhat cxearated, inner margin smooth. Height, 15 millimeters; length, 19 millimeters; diameter, 10 millimeters. $A$ larger but defective valve is 25 millimeters long.

Station 7231. Pliocene. Carter Creek. Collecterl by E. de K. Leffingwell, 1912. U.S. Nat. Mus. catalogue No. 324307.

\section{Astarte hemicymata Dall, n. sp.}

Plate VI, figures 9, 10.

Shell triangular, basally rounded, flattish; beaks narrow, high and pointed, prosococlous; lunule deeply excavated, lanceolate; cscutcheon feebly defined, narrow, obscure; sculpture of seven or eight broad concentric flattish wares with narrower shallow interspaces, obsolete toward the base, and fine fecble incremental lines; hinge compressed with (in the left valre two) slender, somewhat areuate teeth; muscular impressions moderately impressed; inner margins of the valves smooth; anterior end below the lumule erenly rounded into the base; 
posterior end more attenuated, rounded. Height, 20 millimeters; length, about 24 millimeters; diameter, 6 millimeters; but the fragments arailable indicate that it may attain double the above dimensions.

Station 7623. Pliocene. From submarine beach, 30 feet below sea level, half a mile northwest of Nome. Collected by E. M. Kindle and P. S. Smith, 1908. U. S. Nat. Mus. catalogue No. 324308.

\section{Astarte (Gonilia?) diversa Dall, n. sp.}

Plate V, figure 6.

Shell small, rounded triangular, with prominent prosocoelous pointed beaks; nearly equilateral, the anterior end slightly shorter; lunule lanceolate, deeply impressed, concentrically striated, bounded by a sharp angular keel; escutcheon narrow, elongated, obscure; umbonal angle about $90^{\circ}$, dorsal slopes straight, ends and base evenly rounded; sculpture divaricate, some specimens with narrow ribs with the apex central and the interspaces equal, the-ribs becoming wider and more irregular toward the ends of the shell, others with few broad divaricate ribs tending to obsolescence in the middle of the disk, and still others having broad, low ribs irregularly broken up into flattish nodules distributed divaricately but more or less irregularly; cardinal teeth short, narrow, two in the left and one in the right valre; ligament short; margin of the left valve, under the escutcheon, grooved; cavity of the valve extending under the hinge, adductor scars impressed, internal margins of the valves smooth. Height, 15 millimeters; length, 18 millimeters; diameter, 8 millimeters; but reaching a larger size as indicated by fragments.

Station 7623 (1)。 Pliocene. Half a mile northwest of Nome, from submarine beach 30 feet below the level of the sea. Collected by E. M. Kindle and P. S. Smith, 1908. U. S. Nat. Mus. catalogue No. 324309.

This is a remarkable species. The typical Gonilia (bipartita Philippi, as Lucina) is a small Mediterranean shell with a crenulate inner margin and obsolete lunule. Otherwise the only systematic difference is of size. The current descriptions of the original Gonilia are in error in giving it three cardinal teeth in each valve and stating that it has no epidermis.
The latter feature is due to the fact that the specimens dredged have been decorticated single valves. As there was an earlier Astarte bipartita of Sowerby when the Mediterranean species was assigned to the genus, Philippi's specific name could not be retained, and in 1903 I proposed as a substitute the name calliglypta. The present species may, however, be more nearly related to the Pacific Rictocyma than to the Mediterranean Gonilia.

\section{Venericardia nuwokensis Dall, n. sp.}

Plate V, figure 14.

Shell small, rotund, moderately inflated, with slightly prominent beaks, dorsal angle about $85^{\circ}$; sculpture of about 20 radiating ribs with somewhat narrower channeled interspaces, crossed by rather regularly spaced low threads which swell into nodules on the back of the ribs at their intersections; base semicircular, internally crenulate in harmony with the external sculpture; hinge normal, teeth short and very strong for the size of the shell. Height, 13 millimeters; length, 11 millimeters; diameter, 9 millimeters.

Station 7230. Pliocene. Carter Creek. Collected by E. de K. Leffingwell, 1912. U. S. Nat. Mus. catalogue No. 324310.

\section{Macoma middendorffii Dall.}

Plate VI, figures 11, 13.

This peculiar species seems rather characteris tic of the Pliocene at Nome, although in the Recent fauna it is more southern in its general distribution, not having been found living north of Bering Strait. It has been obtained at stations 5074, 5077, 5078, 7619, 7621, and 7622 .

Cyrtodaria camdenensis Dall, n. sp.

Plate $T$, figure 7 .

Shell of moderate size, nearly equilateral, equivalve, gaping at both ends; the umbones subcentral, inconspicuous, the anterior end slightly longer; valves thick, with an unsculptured surface, more or less marked by concentric incremental lines; dorsal and ventral margins nearly parallel, anterior end rounded, posterior end subtruncate, rounded above and below; ligament strong and prominent; adductor scars small, pallial line distinct, entire, with a small round scar at the ventral anterior end 
indieating the attachnent of an area of the mantle; hinge edentulous; a small portion of the periostracum appears to be preserved and shows a black color. Height at umbones, 23 millimeters; length, 48 millimeter's; diameter, 15 millimeters; umbones bohind the anterior end, 25 millimeters.

Station 7070. Pliocene. Horizon C, 100 feet below horizon B, at Carter Creek, Aretic coast, in the Camden Bay region. Collected by E. de K. Leffingwell. U. S. Nat. Mus. catalogue No. 324311.

This is larger and broader than the $C$. kurriana Dunker, the only species now found living on the coast, and differs in ontline from the Atlantic $C$. sitiqua Daudin, which has also a more irregular pallial line and larger adductor sears.

$$
\text { Mya n. sp.? }
$$

'The genus Mrya is represented in the collection only by fragments including the more solid parts of the valve near the hinge. 'The chondrophore is more oblique than in any recent American species and resembles that of Mya juponica, but the receptacle of the flatter valve is entirely different in details from that of any of the boreal species, all of which have been compared with it. This leads to the conclusion that it represents a distinct species, but I refrain from naming it until specimens showing the characters of the entire shell shall have been collected. Numerous defective specimens have been examined. Pliocene.

Fragments were collected at stations $18 \alpha$ and $22 a$ (U. S. G. S. stations 5074 and 507 ) from the second beach within $1 \frac{1}{2}$ miles of Nome, by E. M. Kindle, and at station 7623, from the submarine beach, 30 feet below the sea level, half a mile northwest of Nome, by E. M. Kindle and P. S. Smith. U. S. Nat. Mus. catalogue No. 324312.
BRACHIOPODA.

Hemithyris psittacea Gmelin var. alaskana Dall, n. var.

Plate $V$, figures 4, 5.

Shell very thin, resembling the typical form of the species but much more delicate, pale buff, passing into yellowish gray, surface marked by irregular lines of growth and sculptured with radiating incised lines with much wider interspaces; pedicel valve loss convex than the other, the ninge moderately strong. Ileight, 22 to 25 millimeter's; breadth, 22 to 26 millimeters; diameter of pedicel valve, 6 millimeters; of ventral valve, 9 millimeters.

Station 7618 (19a). Older Pliocene. One mile north of Fort Davis (Gallatin mine), east of Nome, near the parting of Florence and Otter. Creek gulches. Collected by R. D. Mesler, 1908. I. S. Nat. Mus. catalogue No. 324313.

\section{Magasella aleutica Dall.}

I have catalogued this species under the name by which it was originally designated, though I have a suspicion that it represents the Magasella stage of derelopment of some larger terebratelloid species. It does not agree closely with the young of Terelratalia frontalis Middendorff, and Terebratatia coreanica Gould has not been found in the Aleutians. In the absence of any other available species the question must be left open. Pliocene to Recent.

POLYZOA.

Myriozoum n. sp.

At station 7477 , in the dump of an 80 -foot shaft about a mile north of Nome, oceurred fragments of a Myriozoum which were submitted to R. S. Bassler. He reported: "This is usually iclentified as Myriozoum truncatum Pallas but undoubtedly is a distinct species.' The horizon is probably Pliocene. 


\section{PLATES V-VI.}




\section{PLATE Y.}

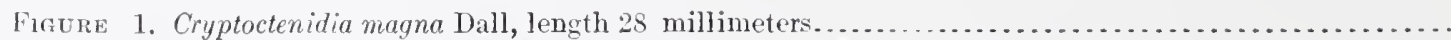

2. Chrysodomus mesleri Dall, fragment showing back of penultimate whorl, diameter 33 millimeters..

3. Chrysodomus mesteri Dall, lyasal fragment, height 32 millimeters.........................

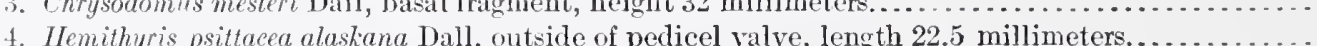

5. Hemithyris psittacea alaskana Dall, outside of ventral valve, diameter 23.5 millimeters...........

6. Lstarte diversa Dall, outside of leit valve, length 18.5 millimeters. . . . . . . . . . . . . . . . . . .

7. Cyrtodaria camdenensis Dall, impression of interior of right valve, length 47 millimeters...........

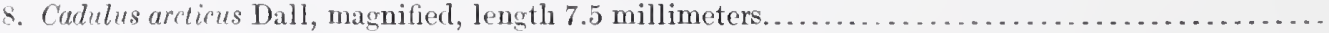

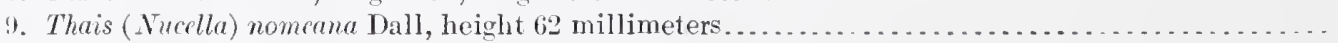

10. Pyrulofusus schraderi Dall, spire viewed from above, diameter 53 millimeters................

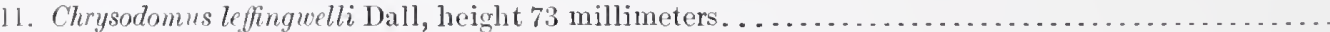

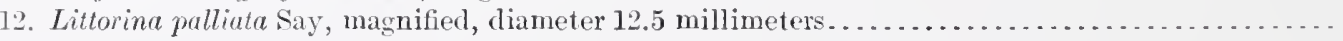

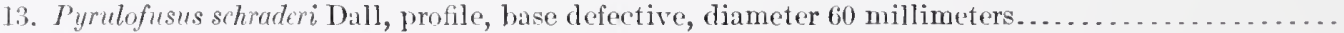

14. I'enericardia nuwokensis Dall, outside of right valve, magnified height 13 millimeters........... 


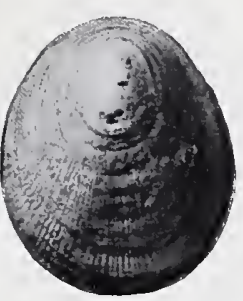

1

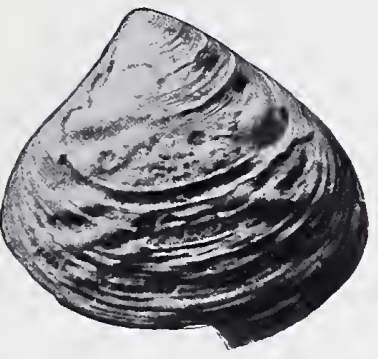

6
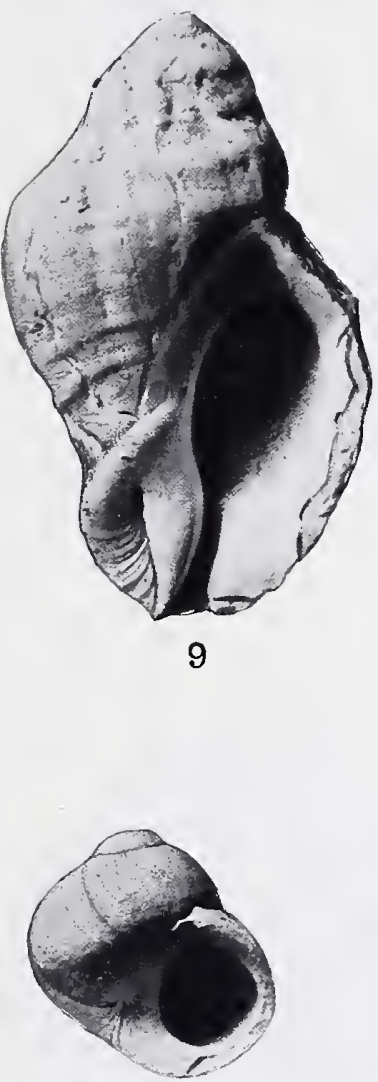

12
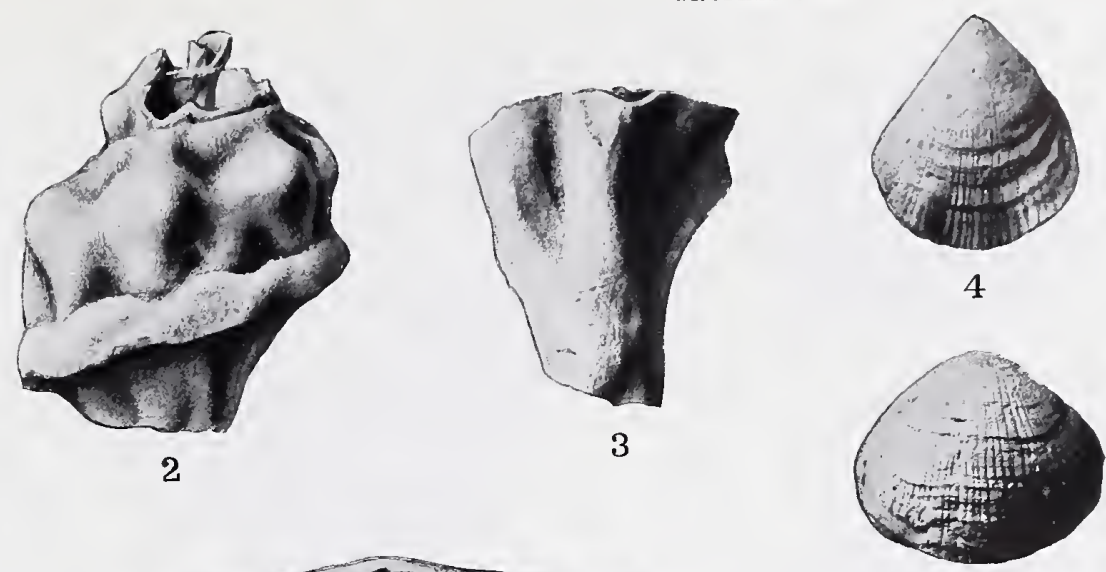

5

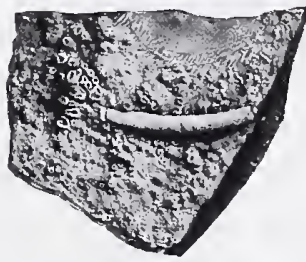

8
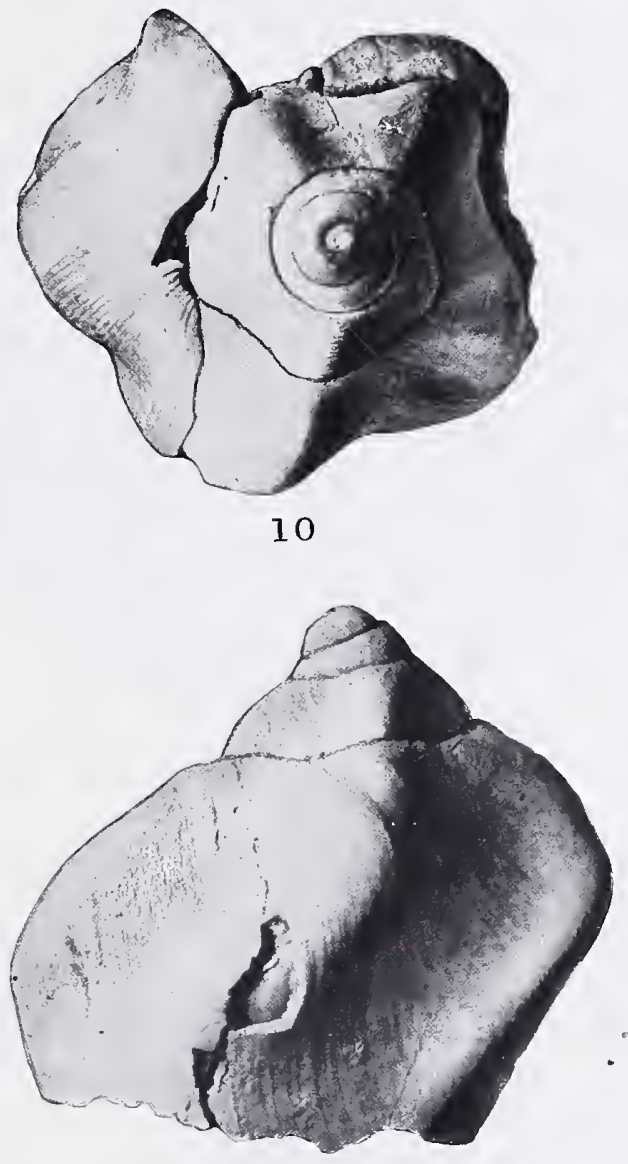

13

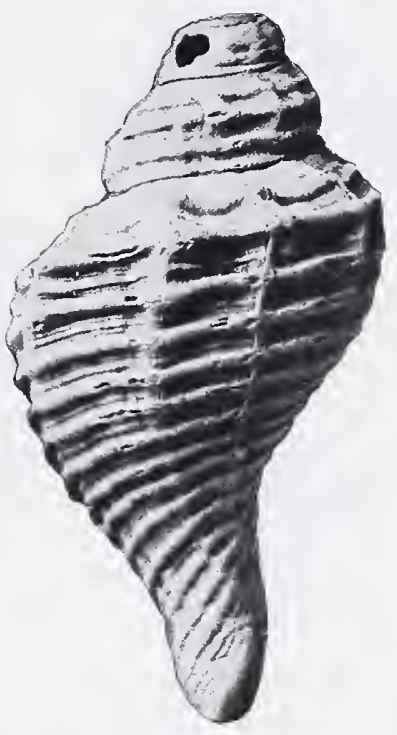

11

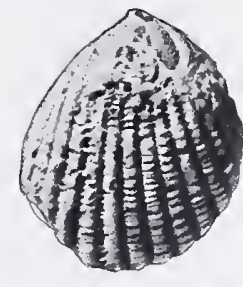

14

ALASKAN FOSSILS. 

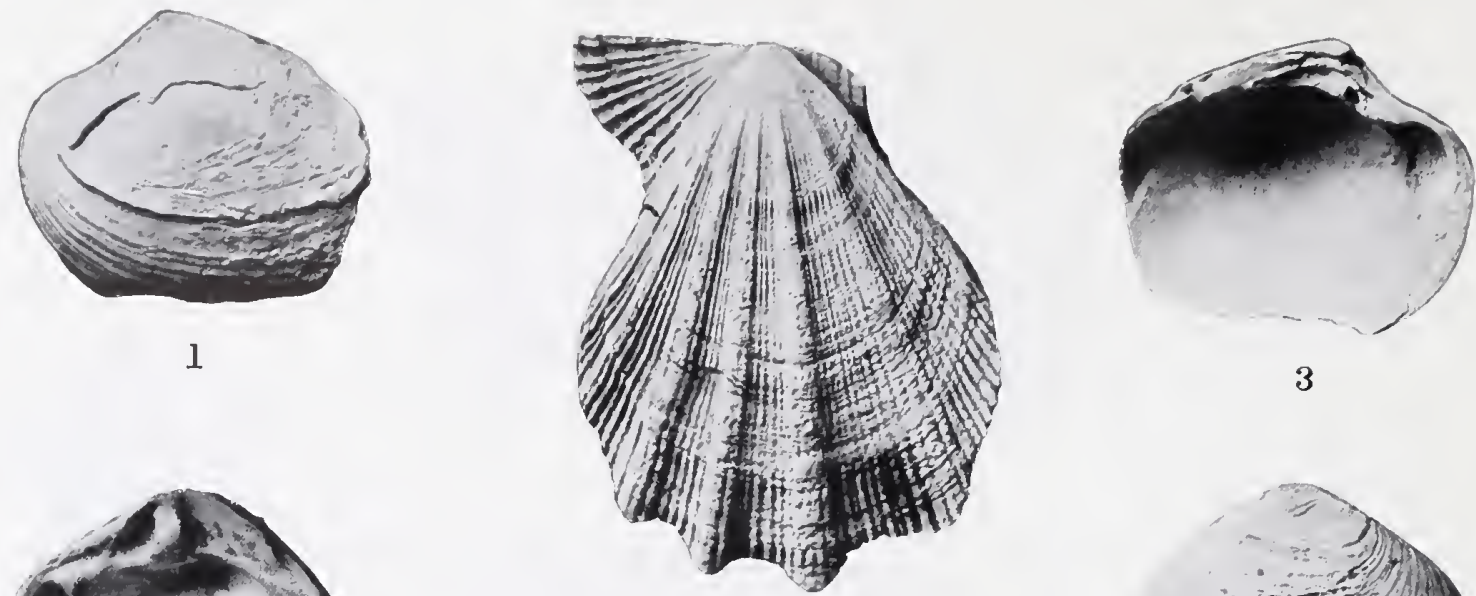

3

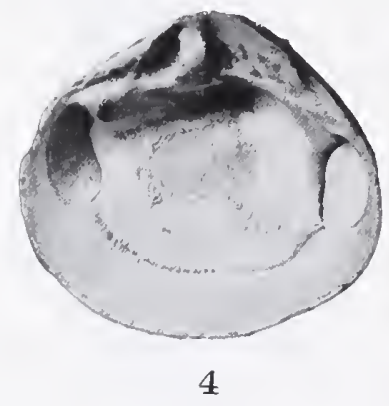

2

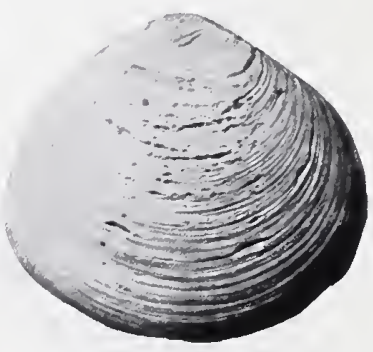

5

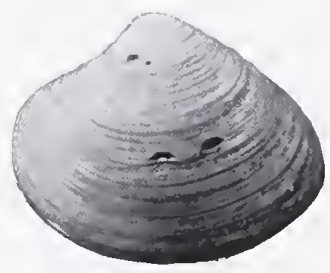

6
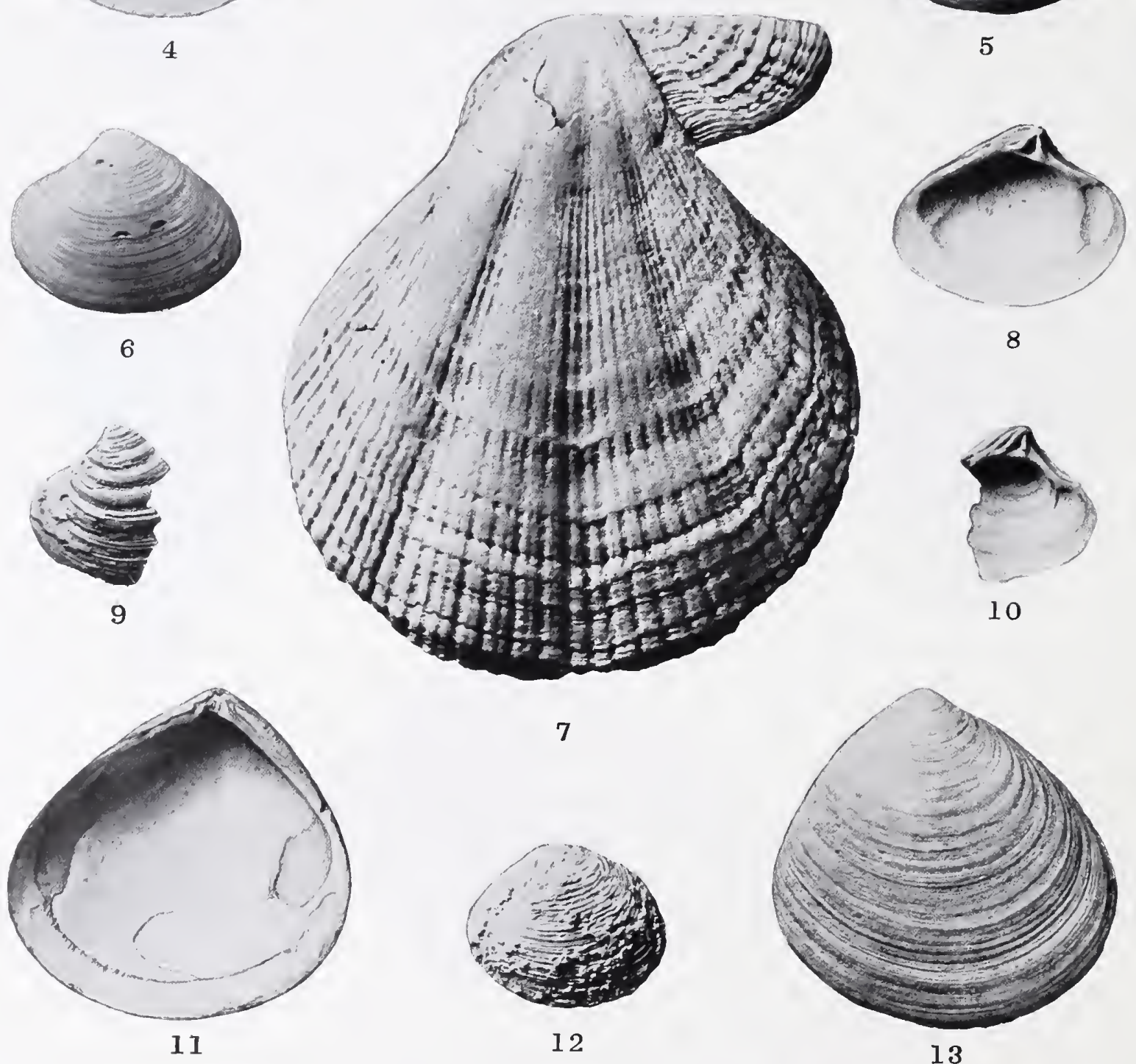

ALASKAN FOSSILS.

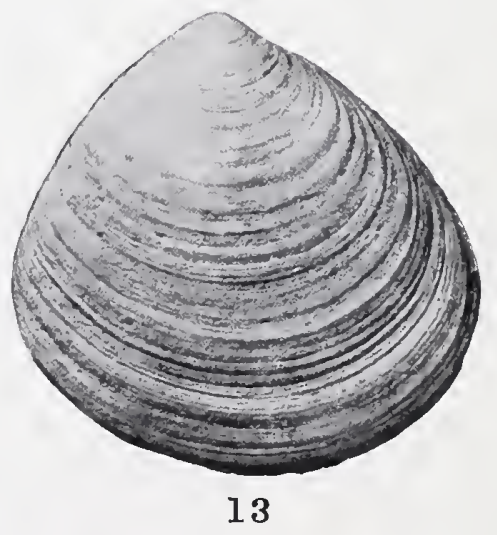




\section{PLATE VT.}

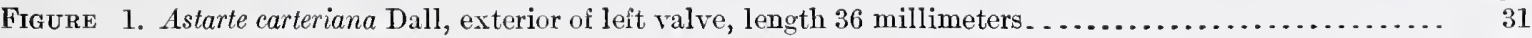

2. Pecten (Chlamys) kindlei Dall, exterior of young leit valve, height 56 millimeters .............. 30

3. Astarte carteriana Dall, interior of left valve, length 36 millimeters.......................... 31

4. Astarte actis Dall, interior of right valve, length 37 millimeters. . . . . . . . . . . . . . . . . . . 31

5. Astarte actis Dall, exterior of leit valve, length 37 millimeters . . . . . . . . . . . . . . . . . . 31

6. Astarte leffingwelli Dall, exterior of left valve, length 31.5 millimeters.......................... 32

7. Pecten (Chlamys) kindlei Dall, exterior of adult right valve, height 91.5 millimeters.............. 30

8. Astarte leffingwelli Dall, interior of left valve, length 31.5 millimeters. . . . . . . . . . . . . . . 32

9. Astarte hemicymata Dall, exterior of (broken) left valve, not quite mature, length 17 millimeters.... 32

10. Astarte hemicymata Dall, interior of same valve. . . . . . . . . . . . . . . . . . . . . . . . . . . . 32

11. Macoma middendorffi Dall, interior of right valve, height 46.5 millimeters . . . . . . . . . . . . . . 33

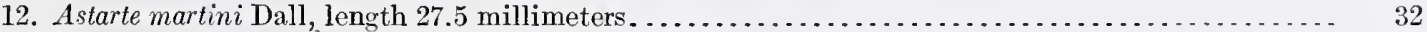

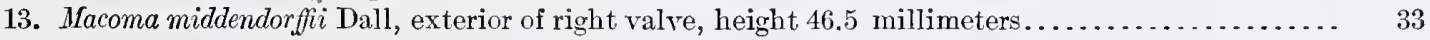




\title{
THE AMERICAN SPECIES OF ORTHOPHRAGMINA AND LEPIDOCYCLINA.
}

\author{
By Joseph A. Cusiman.
}

\section{INTRODUCTION.}

Orbitoid Foraminifera, on account of their short stratigraphic range, have proved to be excellent horizon markers, and, because of their wide geographic distribution, they are valuable in correlation. The genus Orbitoides, as now restricted, is found exclusively in deposits of Cretaceous age; Orthophragmina appears to be confined to the Eocene; but Lepidocyclina ranges through the upper Eocene and Oligocene.

In the present paper are clescribed all the known American species of Orthophragmina and Lepidocyclina. The species are listed below in groups according to the geologic formations in which they are found. The relative ages of the formations are shown in the accompanying correlation table, which is copied from a paper by T. W. Vaughan. ${ }^{1}$ As stated in the footnote to the table, I am not in accord with Douvillé regarding the age of the limestone on Haut Chagres and near David, Panama, but regard it as Eocene because it contains two species of Orthophragmina. However, two of the three species of Lepidocyclina found near David (L. panamensis and L. duplicata) occur also near Tonosi, Panama, associated with fossils characteristic of the middle Oligocene, the age of the lower part of the Culebra formation; and L. chaperi, described originally from Haut Chagres, occurs in the Culebra formation at a higher horizon.

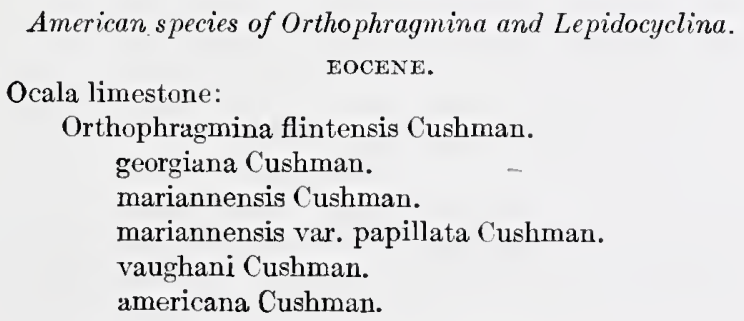

1 The biologic character and gcologic correlation of the sedimentary formations of Panama in their relation to the geologic history of Central America and the West Indies: U. S. Nat. Mus. Bull. 103, table facing p. $595,1919$.
Ocala limestone-Continued.

Lepidocyclina georgiana Cushman, n. sp. fragilis Cushman, n. sp. pseudocarinata C'ushman, n. sp. cookei Cushman, n. sp. attenuata Cushman, n. sp. floridana Cushman, n. sp. pseudomarginata Cushman, n. sp. ocalana Cushman, n. sp. ocalana var. subdecorata Cushman, n. var. hilli Cushman, n. sp.?

Jackson formation:

Lepidocyclina mortoni Cushman, n. sp.

St. Bartholomew limestone:

Orthophragmina marginata Cushman. antillea Cushman. Lepidocyclina antillea Cushman.

Brito formation (Nicaragua):

Orthophragmina hayesi Cushman, n. sp. flintensis Cushman. georgiana Cushman.

David, Panama:

Orthophragmina minima Cushman. antillea Cushman.

Lepidocyclina macdonaldi Cushman. panamensis Cushman. duplicata Cushman.

Haut Chagres, Panama:

Lepidocyclina chaperi Lemoine and R. Douvillé. Cuba:

Orthophragmina cubensis Cushman.

pustulata Cushman.

crassa Cushman.

sculpturata Cushman.

subtaramellei Cushman.

Lepidocyclina perundosa Cushman. subraulinii Cushman.

California:

Orthophragmina clarki Cushman, n. sp. OLIGOCENE.

Marianna limestone:

Lepidocyclina mantelli (Morton).

Byram calcareous marl:

Lepidocyclina supera (Conrad).

Chattahoochee formation:

Lepidocyclina chattahoocheënsis Cushman, n. sp.

Antigua formation:

Lepidocyclina undulata Cushman. undosa Cushman. gigas Cushman. favosa Cushman. canellei var. yurnagunensis Cushman. 
Culebra formation:

Lepidocyclina canellei Lemoine and R. Douvillé. panamensis Cushman?

chaperi Lemoine and li. Nouvillé.

Tonosi, Panama (in beds of the age of the Culcbra formation):

Lepidocyclina panamensis C'ushman. duplicata Cushman.

Emperador limestone:

Lepidocyclina vaughani r'ushman. panamensis Cushman? (uba:

Lepidocyclina schlumbergeri Lemoine and R. Douvillé.

marginata (Michelotti).

kempi (O'Connell).

morgani Lemoine and $\mathrm{R}$. Douvillé.

crassata Cushman.

cancllei var. yurnagunensis Cushman. sumatrensis (Brady).

San Rafael formation, Mexico:

Lepidocyclina gigas var. mexicana Cushmar, n. var.

\section{AMERICAN SPECIES OF ORTHOPHRAGMINA.}

The genus Orthophragmina includes those species of orbitoid Foraminifera in which the chambers of the equatorial hand are rectangular. Many of the species are stellate, with produced angles, or, if circular, have a stellate, raised ornamentation. Others, however, have the circular form with variously ornamented surfaces. The genus so far' as known in America and Europe seems to be linited to the formations of Eocene age, and in America at least it is largely confined to the upper Eocene.

The strueture of the test of Orthophragmina is essentially the same as that of Lepidocyclina. which is diagrammatically figured on page 56 . An equatorial band of chambers, which are rectangular in horizontal section, occupies the middle portion. At either side are the lateral chambers, usually polyonal in outline, and placed one above another in vertical columns. These columns are here and there separated by the pillars, masses of compact shelly material arising from the wall of the eruatorial chambers and thence extending to the surface. The pillars are especially developed in the thicker central region and inerease in diameter toward the surface, where they usually appear as rounded knobs or pustules extending a slight distance above the general surface of the test. Their function seems to be to give strength to the thickened portion of the test.

The lateral chambers and in many species the equatorial chambers also average much smaller than those of most species of Lepido- cyclina. In vertical section the lateral chambers of Orthophagmina, where they are not separated ly pillars, have a zigzag line between adjacent columms, and usually this line serves when once seen to distinguish the genus in rock sections.

Very little has been known of the Anerican species except references to them in papers by II. Douvillé. In 1917 I described several species from the Ocala limestone of Georgia and Florida. ${ }^{1}$ Those species are included in the present paper with additional records for their distribution. Also the material from Cuba, St. Bartholomew, Panama, Nicaragua, and California has been adked, so that the 17 species and rarieties here described cover a wide region. 'There are many other species, but they are not represented by identifiable material. In southern Europe, especially in France and Italy, as many as 10 or 12 species are listed from single localities, showing that in all probability the number of American species will be greatly increased in future work. This paper should therefore be looked upon as only a pioneer attempt at making a basis on which a larger study of the American species can be built. ${ }^{2}$

\section{Orthophragmina cubensis Cushman.}

Plate VI'I, figures $1,2$.

Orthophragmina eubensis Cushman, Carnegie Inst. Washington Pub. 291, p. 52, pl. 9, fig. 3; pl. 10, figs. 2-4, 1919.

Test small, lenticular, comparatively thick; thickness in the center greatest, about threefifths the diameter; circular, gradually thinning toward the periphery l,ut without a definite border; periphery rounded; surface with numerous rather large papillae in the center, gradually smaller toward the periphery.

In vertical section the test, owing to the straightness of the slope from center to periphery, is almost diamond shaped; pillars of the center rery heary, thick, increasing rapilly in diameter toward the surface, the peripheral ends projecting above the adjacent lateral chambers; equatorial chambers of the same height, the band hardly increasing in diameter from center to periphery, very small; lateral

1U. S. Geol. Survey Prof. Paper 108, pp. 115-124; pls. 40-44, 1917. ${ }^{2} \Lambda$ species of Orthophragmina recognized after this paper was in type is describerl in a manuscript now awaiting publication in Prof. Paper 
Tentative correlation table of the Tertiary marine sedimcntary formations of Panama.

[By Thomas Wayland Vaughan.]

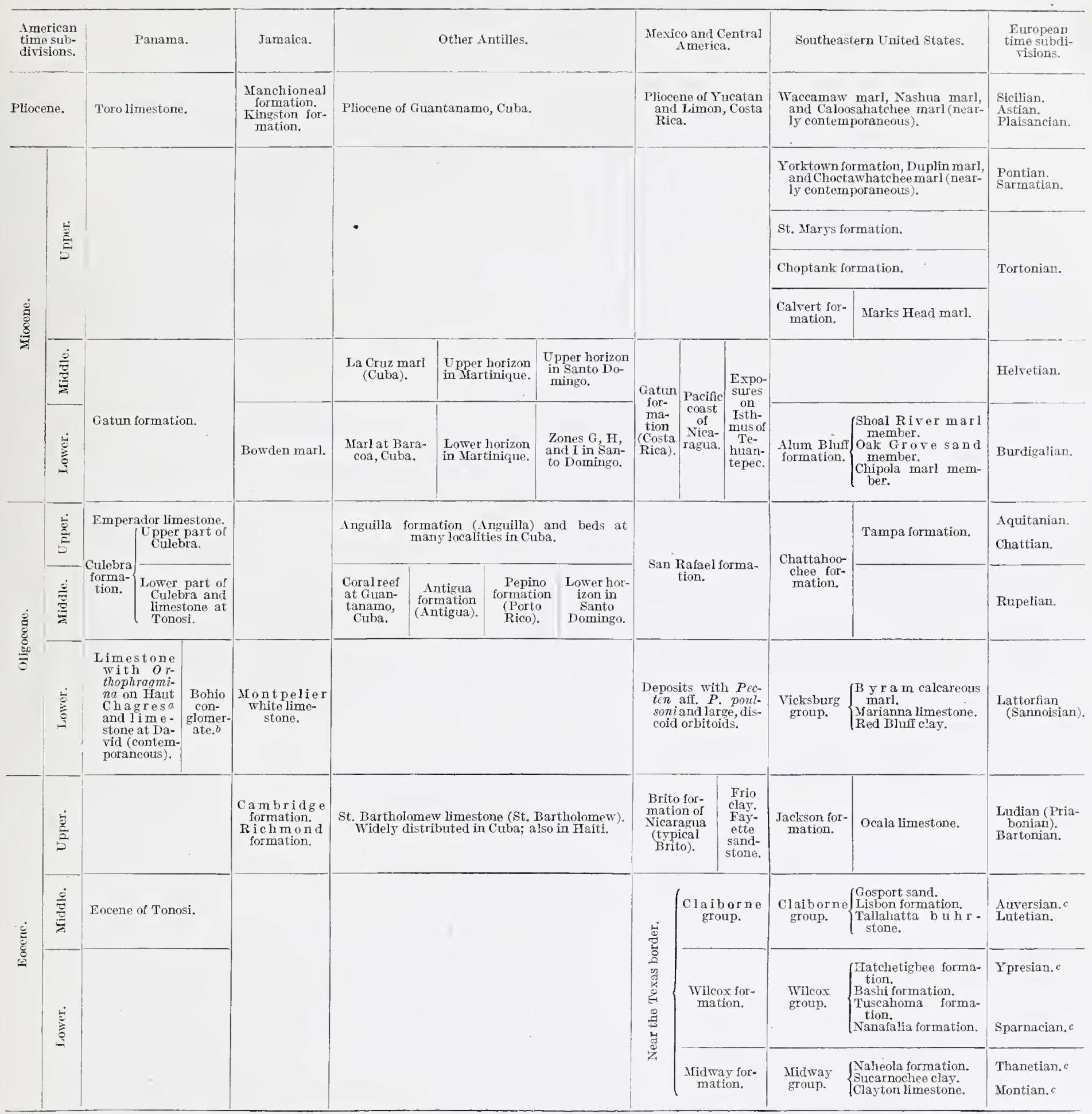

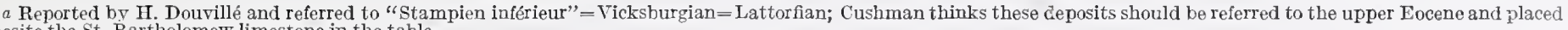
opposite the St. Bartholomew limestone in the table.

c Correlation proposed by E. W. Berry.

$131049^{\circ}-20-4$ 

chambers in vertical columns, up to 20 or more in a column in the thickest central portion, the individual chambers at least four or five times as wide as high in section.

Horizontal sections show the rectangular chambers of the equatorial region several times as long as wide, the lateral chambers forming an irregular network about the sections of the pillars, often several columns of vertical chambers between the pillars.

Diameter, 1.5 to 3.5 millimeters.

Type specimens from U. S. G. S. station 3475 , Boston mine, near Santiago, Cuba; collected by A. C. Spencer.

This seems to be a common Cuban species, occurring in material from several stations as follows:

3448. Limestone from hillside south of Ponupo manganese mine, La Maya, near Santiago; T. W. Vaughan, collector.

6117. Boulder from the band of limestone on hill east of railroad and south of Cristo, near Santiago; C. W. Hayes, collector.

6118. Limestone near railroad on trail to mines south of Cristo; C. W. Hayes, collector.

6119. Isabella and Boston manganese mine, near Santiago; C. W. Hayes, collector.

6120. Loose material, Santiago Province, exact locality unknown.

6122. Greensand limestone, Boston manganese mine, 3 miles east of Cristo, Santiago Province; A. C. Spencer, collector.

6123. Resting on ore bed, 4 to 6 feet thick, Ponupo manganese mine, Santiago Province; A. C. Spencer, collector.

6124. Foraminiferal limestone, Ponupo manganese mine, Ponupo, Santiago Province; R. T. Hill, collector.

6125. Railroad cut near San Nicolas manganese mine, west of San Luis, Santiago Province; C. W. Hayes, collector.

7666. Sierra Guaso, northeast of Guantanamo; N. H. Darton, collector, 1916.

The embryonic chambers of this species so far as seen are unequal in size and very comparable to those seen in the subgenus Nephrolepidina of Lepidocyctina, the larger one kidney shaped and partly embracing the smaller.

In its general characters this species suggests $O$. douvillei Schlumberger, but it differs in several essential details.

Specimens of what is apparently the megalospheric form of this species are abundant in material from the Pilar mine, Oriente Province, Cuba; E. F. Burchard, collector. Some of these are figured in Plate VII, figure 1.
Orthophragmina minima Cushman.

Plate VII, figure 3.

Orthophragmina minima Cushman, U. S. Nat. Mus. Bull. 103, p. 97, pl. 41, fig. 1, 1918.

Test circular, very small, slightly more than 2 millimeters in diameter; thickness somewhat less than half the diameter; central portion very strongly umbonate, nearly rounded to a point about two-thirds of the distance from the center to the periphery; from this point to the periphery the surface is nearly flat; surface of the test comparatively smooth.

The horizontal section through the equatorial chambers shows very fine hexagonal chambers and the embryonic chambers nearly equal in size.

Plate VII, figure 3, shows well the contour of the test in vertical section, the strongly curved central umbonate portion making up two-thirds or more of the width, and the peripheral flange with its nearly parallel sides. The chambers are very small except the embryonic central chambers, which are nearly equal and have a straight division line between. The lateral chambers are in vertical columns, but the test is without pillars. In the central region there may be more than 20 chambers in a vertical column, and even on the peripheral flange there are usually three or four chambers in a column on each side of the equatorial chambers.

Type specimen from U. S. G. S. station 6512 , in the big white limestone from the river bed above the ice plant near David, Panama; D. F. MacDonald, collector.

This is a very small species, yet it has an abundance of very fine chambers. There is an exceptional development of lateral chambers in the region of the periphery.

\section{Orthophragmina clarki Cushman, n. sp. Plate VII, figures 4, 5.}

Test circular, much compressed; central portion somewhat raised and sligh tly umbonate; surface finely granular or papillate; the papillae of the central umbonate region largest and most conspicuous, but others scattered over the remainder of the surface except at the extreme periphery, where they are lacking; slope of the test very gradual from umbo to periphery.

Equatorial chambers typical of the genus, elongate, rectangular, those of the outer annuli 
$1 \frac{1}{2}$ to 2 times as long as broad; annuli somewhat irregular in willth, as is usual in the genus.

The vertical section shows the pillars, which are represented at the surface by the papillae, and the narrow band of equatorial chambers.

Type specimens from northeast side of Domengine Creek, near corner of the SW. it sec. 29, T. 15 S., R. 15 E., Mount Diablo base and meridian, Calif., in Meganos group (Eocene); Dr. Bruce L. Clarts, collector.

This may be the species referred to $O$. pratti by Douville. " IIis specimens were from the peninsula of California.

Orthophragmina pustulata Cushman.

Plate VII, figure 6 .

Orthophragmina pustulata Cushman, Caruegie Inst. Washington Pub. 291, p. 55, pl. 9, figs. 6, 7; pl. 10, fig. 1,1919 .

Test circular, lenticular, thickest in the middle, thence gradually thinning toward the periphery, which is without a carina or thinner portion; thickness about one-fifth the diameter; surface finely pustulose; papillae larger and more numerous near the central region, thence gradually decreasing in size and number toward the periphery.

The vertical section shows the general form; equatorial hand very thin, increasing hardly at all toward the periphery: pillars numerous, somewhat thicker toward the surface.

The horizontal section shows the equatorial chambers clongate, rectangular, length about three times the breadth; annuli irregular in wilth; pillars irregularly rounded, remote, largest in center, decreasing gradually in size toward the periphery; intermediate space filled with the irregularly polygonal lateral chambers.

Diamter 3.5 to 5 millimeters.

Type specimen a section from station 3567 , lowermost 100 feet of 'Tertiary rumning in above serpentine, northwest of Recreo, Matanzas Province, Cuha; 1. C. Spencer, collector. Specimens also apparently of this species were obtained at station 344s, in limestone on hillside south of Panupo manganese mine, La Maya, near Santiago, Cuba;'T. W. Vaughan, collector.

This is a larger, flatter species than $O$. cubensis and is easily distinguished in the sections.

${ }^{1}$ Compt. Rend., vol. 161, p. 410, 1915.
Orthophragmina crassa C'ushman.

I'late VIII, figures 1, 2.

Orthophragmina crassa Cushman, Carnegie Inst. Wasllington Pub. 291, p. 53, pl. 9, figs. 4, 5; pl. 10, figs. $2,4,1919$.

Test circular, lenticular, very thick in romparison with the diameter; central portion broadly convex, thence straight or eren slightly concave to the rather acute periphery: surface fairly smooth, with a fow raised encls of pillars making it slightly papillate.

The rertical section shows the general shape; in some specimens thickness at least two-thirds the diameter; central portion broadly rounded, with numerous large pillars, increasing in diameter toward the surface: lateral chambers very numerous, about three times as wide as high; usually at least two columus between each two adjacent pillars, even in the center; orer 30 chambers in the center in some of the columns are indicated: equatorial chambers increasing very slowly in height toward the periphery but more rapidly than in most species, so that the equatorial band at the periphery may be double the wirlth near the center; embryonic chamber comparatively large, clongate in this section.

The horizontal section shows the usual elongate, rectangular equatorial chambers: the pillars subpolygonal, largest in the center, thence smaller towarl the periphery; intermediate lateral chambers irregularly polygonal.

Diameter, 3.5 to 5.5 millimeters.

Type specimen from station 6122 , greensand limestone, Boston manganese mine, Santiago Province, Cuba; 1. C. Spencer, collector. The species also appears to be present at the following stations:

3475. Boston mine near Santiago, Cuba; A. C. Spencer, rollector.

6117. Boulder from band of limestone on hill east of railroad and south of Cristo, neare Santiago, Cuba; C. W. Ilayes, collector.

6118. Fossil limestone near railroal, on trail to mines south of Cristo, Cuba; C. II. Hayes, collector.

6119. Isabella and Boston manganese mine, Cuba: $C$. IV. IIayes, rollector.

6123. Pollupo manganese mine, resting on ore lied 4 to 6 feet thick, Santiago Province, Cuba; A. C. Spencer, collector.

6124. Foraminileral limestone, Ponupo manganese mine, Culsa; R. T. Hill, collector.

6125. Railroad cut near San Nicolas manganese mine, west of San Luis, Cuba: C. IT. Haves, collector. 
Orthophragmina sculpturata Cushman.

Plate VIII, figures 3-7.

Orthophragmina sculpturata Cushman, Carnegie Inst. Washington Pub. 291, p. 54, pl. 9, figs. 8, 9, 1919.

Test circular, somewhat sellaeform, in many specimens very slightly so; central portion considerably thickened and occupying onethird to one-quarter the diameter of the test; peripheral portion much flattened and comparatively thin; exterior of central thickened portion, when well preserved, beautifully sculptured, with comparatively few raised papillae, between which the surface is depressed and reticulated as in $O$. marthae Schlumberger; peripheral thin portion of the test usually smooth when the surface is well preserved.

Vertical sections show thickening up to 1.5 millimeters in the central portion, while the periphery may be but 0.25 millimeter in thickness. Equatorial chambers small, increasing hardly at all in diameter from the center to the periphery; central embryonic chambers not well shown in the sections but at least six to eight times the diameier of adjacent equatorial chambers. Peripheral portion without pillars; central portion with very strong pillars, thick, with a diameter of onethird to one-half their length and increasing very slightly in diameter toward the surface; lateral chambers in columns between the pillars, very thin compared to their breadth. Central portion of the outline decidedly undulate from the projecting ends of the pillars.

Horizontal sections show very numerous equatorial chambers, elongate, several times as long as broad; lateral chambers in section appearing as polygonal lighter spaces surrounding in a single row the solid, opaque, circular elliptical, or irregularly polygonal pillar sections; toward the periphery, where the pillars are wanting, forming an irregular network-the same arrangement as in 0 . dispansa Sowerby. ${ }^{1}$

Diameter, 5 to 7 millimeters.

Type specimen 3478, from Nuevitas, Cuba; A. C. Spencer, collector. Sections were also obtained in material from the Cadiz mine, Oriente Province, Cuba; E. F. Burchard, collector.

This species in general appearance resembles 0 . marthae Schlumberger, especially in its characteristic surface ornamentation, but the vertical section seems to be verydi fferent from that figured by Schlumberger.

'Schlumberger, Soc. géol. France Bull., sec. 4, vol. 3, pl.12, fig. 51, 1904.
Orthophragmina hayesi Cushman, n. sp.

Plate VIII, figures 8-10.

Test small, lenticular, circular, comparatively thick in the center, thence gradually becoming thinner and at the peripheral portion in the adult extending out into a broad, thin flange; central disk with numcrous deep pits, circular or polygonal, usually four or five in the central region of larger size, the surrounding ones gradually smaller as they are more distantfrom the center ; remainder of the surface reticulate, from the lateral chambers as they come to the exterior.

Equatorial chambers of the usual rectangular form of this genus.

Tertical sections (Pl. VIII, fig. 10) show the large number of lateral chambers in each column and the flangelike peripheral portion not shown in the exterior views of the worn specimens (figs. 8, 9).

Type specimens (U. S. N. M. No. 32S20) from U. S. G. S. station 6411, Brito formation, coast about 2 miles northwest of Brito Harbor, Nicaragua; C. W. Hayes, collector.

\section{Orthophragmina marginata Cushman.}

Plate IX, figures 1, 2.

Orthophragmina marginata Cushman, Carnegie Inst. Washington Pub. 291, p. 56, pl. 1, fig. 2; pl. 2, fig. 4, 1919.

Test circular, lenticular; central portion strongly raised and umbonate; regularly curved down to the broad peripheral flange, which is again thickened near the peripheral margin; surface comparatively smooth, rery slightly granular but not at all papillate.

In vertical section the central portion is seen to be strongly biconvex, not much wider than either part of the surrounding margin-like thinner portion, again thickening toward the extreme peripheral margin, which is rounded. Equatorial chambers small, in the center very narrow but increasing slightly although gradually toward the periphery, where they are not more than 0.1 millimeter in height. 'The chambers are convex on the peripheral side, almost semicircular in some specimens. Lateral chambers very small and often difficult to distinguish even with an enlargement of 20 diameters (Pl. IX, fig. 2). In the central portion there are large numbers of layers of the lateral chambers, often 30 to 40 on either side of the equatorial band. This number decreases as the 
convexity becomes less, and orel the flattened margin there are but six to eight la yers of lateral chambers. It the border this number is somewhat increased, but it falls off again at the extreme outer margin. 'There are traces of pillars in the central nmbonate region, but they are not prominent.

Dianneter of type sperimen 12 to 14 millimeters.

Type specimen and others from U.S. G.S. station 6924, from the St. Bartholomew limestone at point on northwest sicle of St. Jean Bay, St. Bartholomew, Leeward Islands; collecterl by T. W. Vaughan. The St. Bartholomew limestone is of upper Eocene age, according to Vaughan.

There are sections which resemble this closely in the material from U. S. G. S. station 6512, in the big white limestone from the river bed abore the ice plant near David, Panama; collected by D. F. MacDonald.

\section{Orthophragmina flintensis Cushman.}

Plate IX, figures 3-6.

Orthophragmina flintensis Cushman, U. S. Geol. Survey Prof. Paper 10s, p. 115, pl. 40, figs. 1, 2, 1917.

Test small, eireular, much compressed; slightly thickened in the central portion, thence gradually sloping to the periphery; surface slightly pustulate but not papillate, almost smooth in some specimens; the raised pustules generally in concentrie lines.

The horizontal section shows rery narrow rectangular chambers in the equatorial band and the embryouic rhambers with one small and spherical, almost entirely surrounded, except at one side, by the much larger second chamber.

Diameter, about 5 millimeters.

The type locality is U. S. G. S. station 7117 , in the lower portion of the Ocala limestone, in bluff on west bank of Flint River $1 \frac{3}{2}$ miles above the Georgia Southwestern \& Gulf Railway bridge near Oakfield, Lee County, Ga.; upper bed, No. 2 of sertion; C. W. Cooke, collector. Other stations mentioned with the original description are mostly along Flint River in Georgia, in fine-grained light-colored limestone. It also occurs at station 3626, in a similar fine-grained limestone at Philema, Lee County, Ga.; T. W. Vaughan, collector.
A sperimen which seems identical with this species was obtained at station 6408 , in the Brito formation, on the Pacific coast of Nicaragua, 2 miles northwest of Brito Harbor; C. W. Hayes, collector. This specimen shows the size and exterior well, while others show the equatorial chambers. With this is a species of Operculina, which also occurs with it in Georgia, and a specimen of $O$. georgiana, as noted under that speries (p. 45).

\section{Orthophragmina floridana Cushman.}

Plate IX, figure 7.

Orthophragmina floridana Cushman, U. S. Geol. Survey Prof. Paper 108, p. 116, pl. 40, fig. 3, 1917.

Test cireular, much flattened, of medium size; central region very slightly raised and umbonate, thence gradually sloping toward the periphery; whole test rery thin; surface ormamented throughont with fine but distinctly raised, almost spinose papillae, arranged in coneentrie lines parallel to the peripheral margin.

Equatorial chambers in horizontal section very narrowly rectangular.

The rertical section shows $\&$ to 10 lateral chambers in a rertical column in the central portion, the walls convex on the side nearer the surface, the whole scries conrex at each papilla instead of parallel to the equatorial series, the papillae being formed by the loeal convexity of the lateral chambers rather than by pillars as in some other species.

Diameter of adult specimens, 10 to 14 millimeters.

The type loeality is U. S. G. S. station 6768, in soft white Oeala limestone on Chipola River at wagon bridge half a mile east of Marianna, Fla., No. 1 of section; C. W. Cooke, collector. The species is abundant at this locality. Additional records are the following:

7192. Same locality as the type station, No. 3 of section; C. W. Cooke, collector, a single horizontal section in hard limestone.

8259. About 6 miles southeast of Campbellton and 12 miles northwest of Marianna, on road to Cottonwood, Ala., half a mile from its intersection with the Marianna-Campbellton road, in Jackson County, Fla.; C. W. Cooke, collector. Abundant in soft Ocala limestone.

7125. West bank of Flint River in Baker County about 3 miles below Dewberry Ferry (Baconton Landing) and about 13 miles above Newton, Ga.; a single spccimen of small size; J. E. Brantly and C. W. Cooke, collectors. 
Orthophragmina georgiana Cushman.

Plate $\mathrm{X}$, figure $\mathrm{I}$.

Orthophragmina georgiana Cushman, U. S. Geol. Survey Prof. Paper 108, p. 117, pl. 41, figs. 2, 3; pl. 42, fig. 3; pl. 43, figs. 2, 3, 1917.

Test typically almost square, the angles slightly projecting and the sides slightly concave near the angles, convex in the center, small; diameter usually about 6 millimeters for adult specimens; diagonals of the square occupied by raised radial areas with a central umbonate mass a littie more than a millimeter in cliameter; intermediate triangular areas thin and flat; entire suriace with very numerous, evenly distributed, prominent papillae, those of the central umbo and the middle line of the radial ridges slightly larger than those of the rest of the surface.

The horizontal section shows the equatorial chambers elongate, rectangular, those of the radial portions more crowded than those of the intermediate flattened areas.

In vertical section the lateral chambers are most numerous over the radial and umbonal regions.

The type locality for this species is station 3387, Ocala limestone at Red Bluff, on Flint River 7 miles above Bainbridge, Decatur County, Ga.; T. W. Vaughan, collector. It was recorded also from several stations along Flint River in Georgia and from station 7348, on left bank of Suwannee River about a mile above Troy Springs, Fla.; C. W. Cooke, collector.

Additional records include stations in Georgia, Florida, and Alabama, as follows:

3758. Camp Perry, Fla.; S. W. IfcCallie, collector; a few specimens.

3760. On Georgia Southern \& Florida Railway half a mile south of Tivola, Ga.; S. W. McCallie, collector.

6161. Flint River, Bainbridge, Ga.; L. W. Stephenson, collector.

6747. Steamboat Point, on west side of Sepulga River at sharp bend near middle of sec. 20, T. 3 N., R. 13 E., Escambia County, Ala.; C. W. Cooke, collector; specimens fairly common with other Ocala limestone species.

6785. Atlantic Coast Line Railroad at Dutton's phosphate spur, one-half to three-fourths mile south of Herlong's Station, Columbia County, Fla.;T. W. Vaughan and C. W. Cooke, collectors; specimens rare but typical.

7127. East bank of Flint River, one-fourth mile below Norman's Ferry, Mitchell County, Ga.; loose blocks excavated from channel; C. W. Cooke, and J. E. Brantly, collectors.
8259. About 6 miles southeast of Campbellton and 12 miles northwest of Marianna, on road to Cottonwood, Ala.; half a mile from its intersection with the MariannaCampbellton road, Jackson County, Fla.; C. W. Cooke, collector.

I single specimen of this species was found at station 6408, in the Brito formation on the Pacific coast of Nicaragua, 2 miles northwest of Brito Harbor; C. W. Hayes, collector. This occurs with two other Georgia species, as noted under $O$. fintensis.

Orthophragmina subtaramellei Cushman.

Plate $\mathrm{X}$, figures 2, 3 .

Orthophragmina subtaramellei Cushman, Carnegie Inst. Washington Pub. 291, p. 533, pl. 10, fig. 2; pl. 15, figs. 1-3, 1919.

Test stellate, usually with five arms, occasionally six; arms well distinguished from the central body and extending outward freely, thickest in the central region, thence gradually sloping to the angles between the arms and gradually merging into the median axis of the arms; the arms themselves thickest in the middle, thence sloping to the sides, which are thin and angled; ends of the arms round-pointed; surface with numerous granulations, more pronounced in the central portion.

Vertical sections show the general shape, the equatorial band of chambers increasing slightly if at all from the center to the periphery, pillars well developed, especially in the central region, but not numerous, usually several columns of lateral chambers between them.

Diameter, 1.5 to 2 millimeters.

The type locality for this species is station 6122 , greensand limestone, Boston manganese mine, Santiago Province, Cuba. According to the sections obtained, the species evidently also occurs at the following stations:

3475. Boston mine, near Santiago, Cuba; A. C. Spencer, collector.

6119. Isabella and Boston manganese mine, Santiago Province, Cuba; C. W. Hayes, collector.

6123. Ponupo manganese mine, Santiago Province, Cuba, resting on ore bed 4 to 6 feet thick; A. C. Spencer, collector.

6124. Foraminiferal limestone, Ponupo manganese mine; R. T. Hill, collector.

6125. Railroad cut near San Nicolas manganese mine, west of San Luis, Cuba; C. W. Hayes, collector.

7666. Sierra Guaso, northeast of Guantanamo, Cuba; N. H. Darton, collector. 
This species is very close to O. taramelle $i$ Municr-('halmas but is decidedly smaller, all the spereimens seen from (uba being less than 2 millimeters in diameter between the tips of the arms.

The specimens from station 6120 are weathered out and are numerous and of greenish color.

O. taramell $i$ was described from Villa Lady Bruce (Biarritz); Monte Spileceo (Vicentin); and Schönegg, near Kressenburg.

Crthophragmina antillea Cushman.

Plate $\mathrm{X}$, figures 4,5 .

Orthophragmina antillca Cushman, Carnegie Inst. Washington Pub. 291, p. 55, pl. 1, fig. 1; pl. 2, figs. 2, 3; 11. 4, figs. 2, 4, 1919.

Test flattened, octagonal, surface with eight raised ribs radiating from the central, somewhat raised umbo to the periphery; triangular areas between, thin and flattened; umbonal area raised and rouncled, with definite pillars appearing as differences in coloration in the type; radial ribs with numerous raised areas and pillars scattered along their whole length.

Vertical sections show the sreater diameter of the equatorial chambers at irregular intervals and the irregular, almost serrate character of the upper and lower surfaces due to the fine projections of the surface, especially along the ribs.

Horizontal sections through the equatorial chambers were obtained only in small fragmentary bits but enough to show the typical rectangular chambers of the genus.

Diameter, about 12 millimeters.

Type specimen from L. S. G. S. station 6595, spur on southeast side of bay northwest of St. Jean Bay, St. Bartholomew, Leeward Islands; T. W. Vaughan, collector. Sections apparently of this species came from station 6924, point on northwest side of St. Jean Bay, St. Bartholomew, Leeward Islancls; T. W. Vaughan, collector. Specimens are very numerous in these sections, but the surface does not weather out well in the material examined.

There appear to be from five to eight layers of superimposed lateral chambers, as shown in the sections. A few of the smallest specimens show the embryonic chambers, but they are not well preserved. Plate $\mathrm{X}$, figure 5, shows the general characters of the vertical section. Occasional oblicue sections show the rectangular equatorial chambers characteristic of Orthophragmina. Sections very similar to those figured are included in material from station 6512 , in the big white limestone from the river bed above the ice plant near David. Panama, collected by D. F. MacDonald.

The species is close to $O$. mariannensis Cushman from the Ocala limestone at Marianna, Fla.

The type specimen is the one mentioned by Vaughan" as Orbitoides sp., "large, stellate form."

\section{Orthophragmina mariannensis Cushman.}

Plate XI, figure 1.

Orthophragmina mariannensis Cushman, U. S. Geol. Survey Prof. Paper 108, p. 116, pl. 40, fig. 5 ; pl. 42, fig. 2 ; pl. 44, 1917.

Test flattened, conspicuously stellate, the angles extending out acutely with curved reentrants, of medium size; central region umbonate, from which extend 8 to 11 (typically 8 ) raised ribs, running to the peripheral angles; umbo and ribs finely papillate; depressed areas between flat and rather remotely and finely papillate except toward the periphery, where the papillae are slightly more conspicuous.

The horizontal section shows much elongated rectangular equatorial chambers, the lateral chambers irregularls polygonal in section.

Tertical section with the embryonic chambers rery unequal; distinct pillars hetween the vertical columns of lateral chambers, increasing in diameter toward the surface.

Diameter, 15 to 18 millimeters.

Abundant at the type locality, station 6768 , Ocala limestone on Chipola River at wagon bridge half a mile east of Marianna, Fla.; No. 1 of section; C. W. Cooke, collector. A single specinen was recorded from station 33S7, Ocala limestone at Red Bluff, on Flint River, 7 miles above Bainbridge, Decatur County, Ga.; T. W. Vaughan, collector. Additional stations are as follows:

7097. East bank of Flint River above old factory at bend three-fourths mile northeast of Atlantic Const Line Railroad station at Bainbridge, Gr.; C. W. Cooke and W. C. Mansfield, collectors.

8259. Ahout 6 miles soutbeast of Campbellton and 12 miles northwest of Marianna, on road to Cottonwood, Ala., half a mile from its intersection with the Harianna-Campbellton road, Jackson County, Fla.; C. W. Cooke, collector.

1 Vaughan, T. W., Carnegie Inst. Washington Year Book No. 13, Ior $1914, \mathrm{p} .359$. 
Orthophragmina mariannensis Cushman var. papillata Cushman.

Plate XI, figure 2.

Orthophragmina mariannensis Cushman var. papillata Cushman, U. S. Geol. Survey Prof. Paper 108, p. 117, pl. 43, fig. 1; pl. 44, 1917.

Variety ciffering from the typical form of the species in the much more prominent, higher ribs, which are semicylindrical and very strongly papillate; number of ribs also slightly greater than in the typical form; a few specimens have 8 , but 9 to 12 or even 16 ribs are more common.

The type station for this variety is the same as that for the species, station 6768 . It was also recorded from stations along the Flint River in Georgia. Additional records for this variety are as follows:

7130. East bank of Flint River, 6 miles above Bainbridge, Decatur County, Ga.; C. W. Cooke and J. E. Brantly, collectors; a single very typical specimen.

8259. About 6 miles southeast of Campbellton and 12 miles northwest of Marianna, on road to Cottonwood, Ala., half a mile from its intersection with the Marianna-Campbellton road, Jackson County, Fla.; C. W. Cooke, collector.

Orthophragmina vaughani Cushman.

Plate XI, figure 3.

Orthophragmina vaughani Cushman, U. S. Geol. Survey Prof. Paper 108, p. 118, pl, 43, figs. 4, 5, 1917.

Test flattened, small, 8 to 10 milliméters in diameter, quadrate or octagonal in outline, stellate; main ornamentation consisting of a central raised umbonate portion with four radiating raised areas to the main angles of the test, broad and rather low, about halfway to the periphery considerably increasing in height and width, finely papillate toward the center, much more coarsely so toward the periphery; intermediate spaces much depressed, with a smooth U-shaped area near the inner angle next to the raised portions; the peripheral part raised and strongly papillate, the peripheral portion of this raised area at the margin strongly convex or even bluntly angled.

The ornamentation of this species is unique. It is evidently a rare species, being known only from the type locality, U.S. G. S. station 3387, Ocala limestone at Red Bluff, on Flint River 7 miles above Bainbridge, Decatur County, Ga.; T. W. Vaughan, collector.
Orthophragmina americana Cushman.

Plate XI, figure 4.

Orthophragmina americana Cushman, U. S. Geol. Survey Prof. Paper 108, p. 116, pl. 40, fig. 4; pl. 41, fig. 1; pl. 42 , fig. 1.

Test large, flattened; peripheral margin with a series of projecting angles corresponding to the peripheral terminations of the radiately arranged raised ornamentation or thickenings; peripheral margin between the projecting angles very thin; central region with a thickened umbo 2 millimeters or more in diameter, from which radiate the raised riblike areas to the peripheral angles; these ribs high and narrow at their inception, lower and wider as they approach the periphery; ribs up to 20 in number; some starting from the umbo, others initiated later, arising independently in the intermediate areas, usually not symmetrically piaced; surface comparatively smooth; surface indications of pillars usually inconspicuous or lacking.

In vertical section the equatorial chambers are rectangular, the area of the raised radial portions consisting of more numerous lateral chambers in the columns, curving about the axis at the rib at either side, those of the intermediate depressed areas parallel with the equatorial layer and few in number.

In horizontal section the equatorial chambers are rectangular, four or five times as long as wide, those of the axis of the radial portions narrower than those of the intermediate depressed areas.

The type locality for the species is U. S. G. S. station 6768, Ocala limestone on Chipola River at wagon bridge a quarter of a mile east of Marianna, Fla.; No. 1 of section; C. W. Cooke, collector. Another station is 3387, Ocala limestone at Red Bluff, on Flint River 7 miles above Bainbridge, Decatur County, Ga.; T. W. Vaughan, collector. Other specimens came from station 8259, Ocala limestone about 6 miles southeast of Campbellton and 12 miles northwest of Marianna, on road to Cottonwood, Ala.; half a mile from its intersection with the Marianna-Campbellton road, Jackson County, Fla.; C. W. Cooke, collector.

This is a fine species, one of the largest of the genus. 



\section{PLATES VII-XI.}




\section{PLATE V'II.}

\section{Orthophragmina cubensis Cushman (p. 40).}

Fugure 1. Rock sectiou showing several sperimens, $X 20$, mostly of the megalospheric form. Pilar mine, Oriente Proviuce, Cuba.

FiGUre 2. Vertical section probably of a nicrospheric specimen, $X 20$. (uba (U. S. G. S. station 3448 ).

\section{Orthophragmina minima Cushman (p. 41).}

Fig URE 3. Vertical section, $\times 20$, showing general outline and numerous very fine chambers. White limestone in river bed above ice plant, David, Panama (I'. S. G. S. station 6512).

\section{Orthophragmina clarki Cushman (p. 41).}

FIGURE 4. Exterior view of partly grown specimen, $\times 10$.

Figure 5. Exterior view of adult specimen, $\times 10$. Both specimens from the Eocene of (alifornia (Meganos group of Clark).

Orthophragmina pustulata Cushman, n. sp. (p. 42).

FICURE 6. Slightly oblique section showing equatorial chambers, pillars, and lateral chambers, $X 20$. (uba (T.S. G. S. station 3567 ). 50 

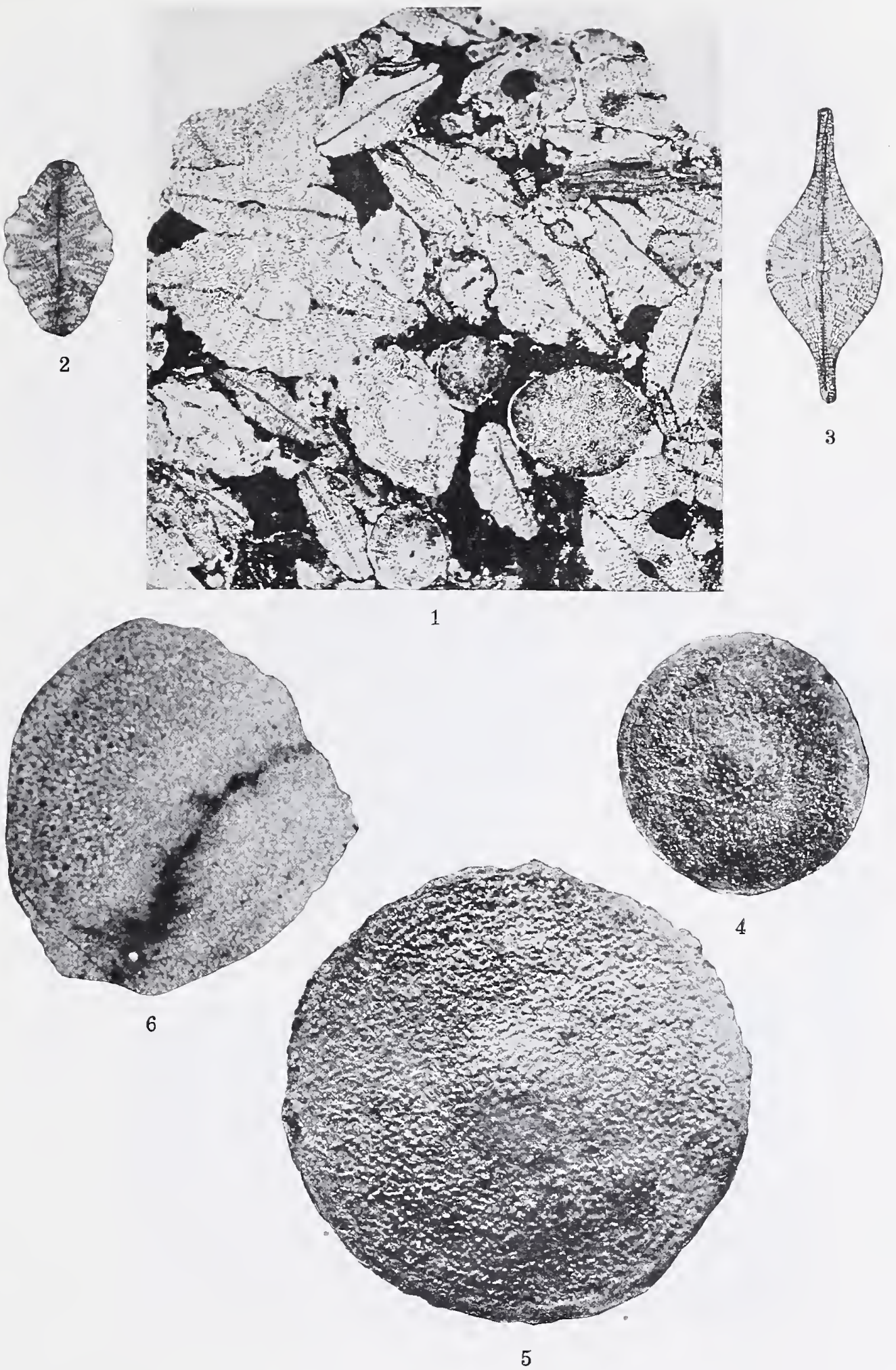

AMERICAN SPECIES OF ORTHOPHRAGMINA 

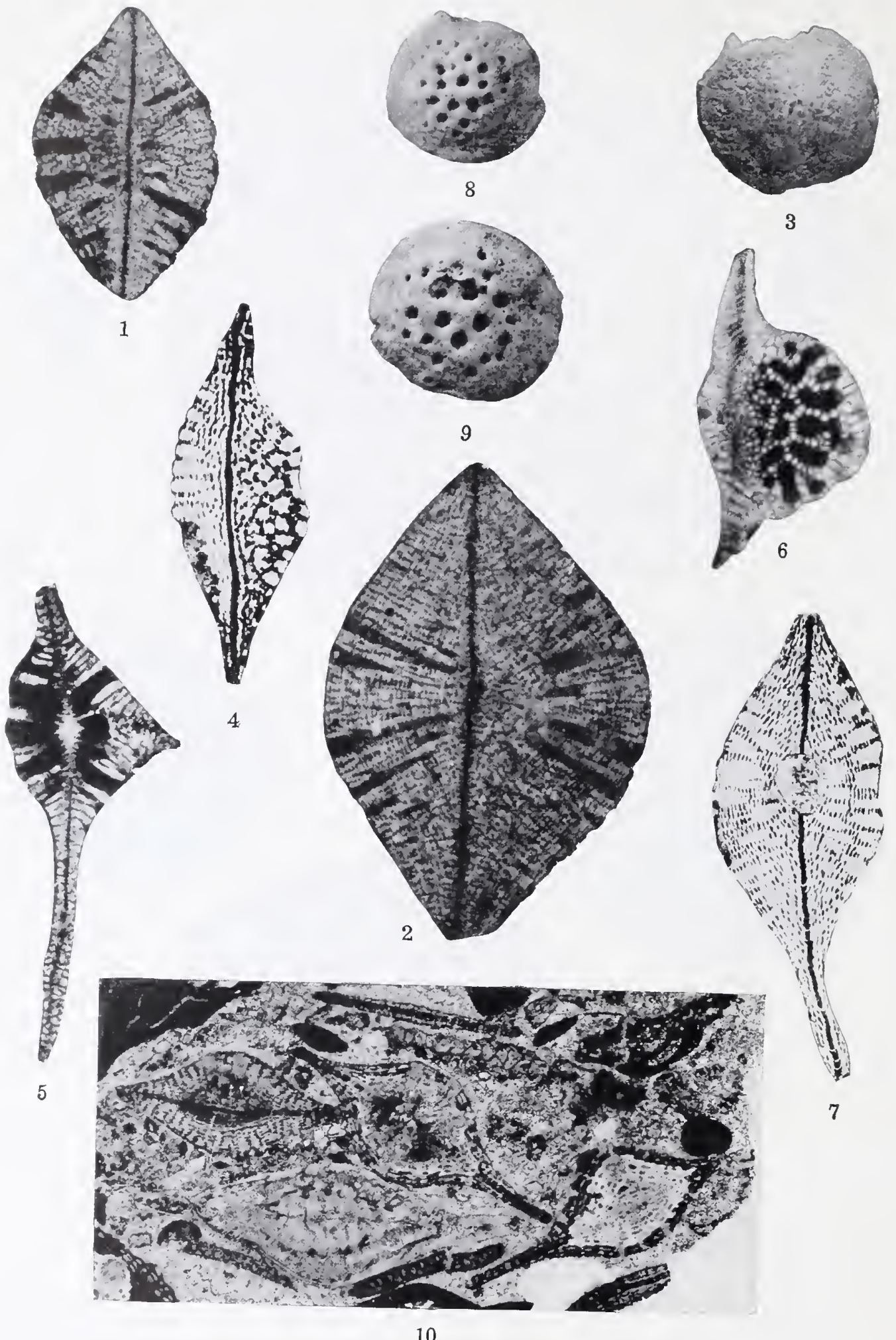

A MERICAN SPECIES OF ORTIOPHRAGIINA.

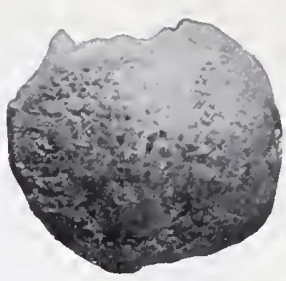

3

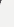




\section{PLATE VIII.}

\section{Orthophragmina crassa Cushman (p. 42).}

Figure 1. Vertical section, $\times 20$, showing general thick form, equatorial band, large number of lateral chambers, and the pillars.

FIGURE 2. Vertical section of larger specimen, $\times 20$. Both specimens from Cuba (U. S. G. S. station 6122).

Orthophragmina sculpturata Cushman (p. 43).

Figure 3. Exterior view showing the few pillars of the central portion and reticulate peripheral portion, $\times 5$. Cuba (U. S. G. S. station 3478).

Frgure 4. Slightily oblique section, $\times 20$. Gloria mine, Oriente Province, Cuba. The black of the chamber cavities is due to infiltrated manganese in this and the specimen of figure 7 .

Figure 5. Vertical section showing heavy pillars, $\times 20$. Cuba (U. S. G. S. station 3478).

Figure 6. Oblique section showing the large pillars, each surrounded by a single series of small lateral chambers, $\times 20$. Cuba (U. S. G. S. station 3478).

Figure 7 . Vertical section, $\times 20$, probably of megalospheric specimen, showing the structures shown in figure 6 but at right angles, the elongate large pillars, and vertical rows of lateral chambers (in black). Same locality as figure 4 .

Orthophragmina hayesi Cushman, n. sp. (p. 43).

Figures 8 , 9. Exterior views of two specimens, $\times 20$, showing the deep pits of thecentral region and the reticulate pattern over the remainder of the surface. These and the following from the Brito formation (Eocene) of Nicaragua.

Figure 10. Vertical sections showing the peripheral flange as developed in adult specimens, $\times 20$. 
PIATE IX.

Orthophragınina marginata Cushman (p. 43).

Figure 1. Exterior view of partly broken specimen, $X 5$. St. Jean Bay, St. Bartholomew, Leeward Islands (U.S. G. S. station 6921).

Ficure 2. Tertical section, $\times 20$, of half a specimen from the same locality.

Orthophragmina flintensis Cushman (p. 44).

Figure 3. Exterior view, $\times 10$, of specimen from the Brito formation of Nicaragua (U. S. G. S. station 6408). Figure 4. Sectional horizontal view of type specimen, $X 20$, showing proloculum and second ehamber, which nearly encircles it, and the annular rings of narrowly rertangular chambers. Ocala limestone of Georgia (U.S.G.S.7115).

Figures 5, fi. Tertical seetions, $\times 20$, showing the numerous enlargements along the line of equatorial chambers and the pillars ending in the papillae of the surface. Nicaragua (U. S. G. S. station 6408).

Orthophragmina floridana Cushman (p. 44).

FIGURE 7. Surface view of type specimen, $X 8$. Ocala limestone of Florida (U. S. G. S. station 6768). 

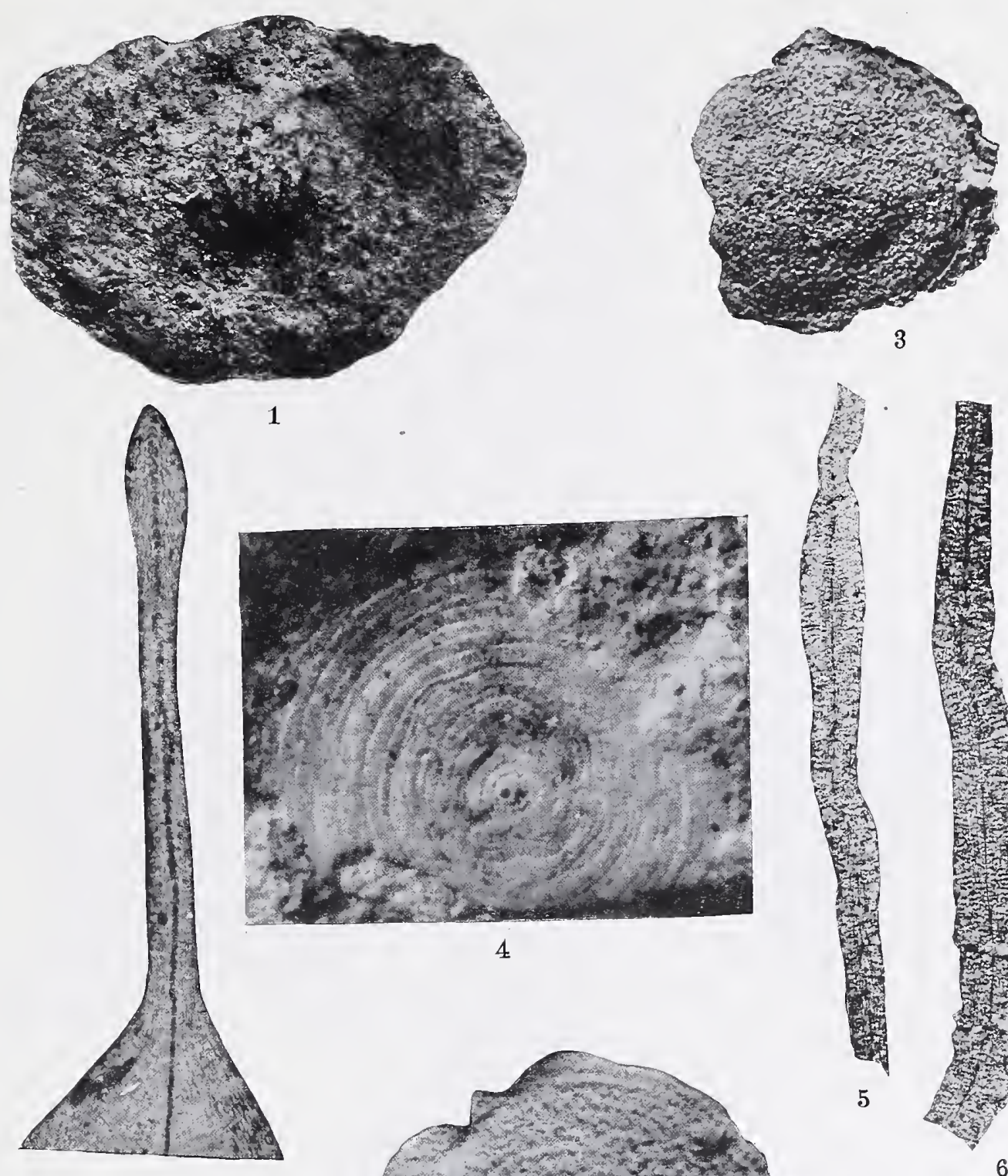

1

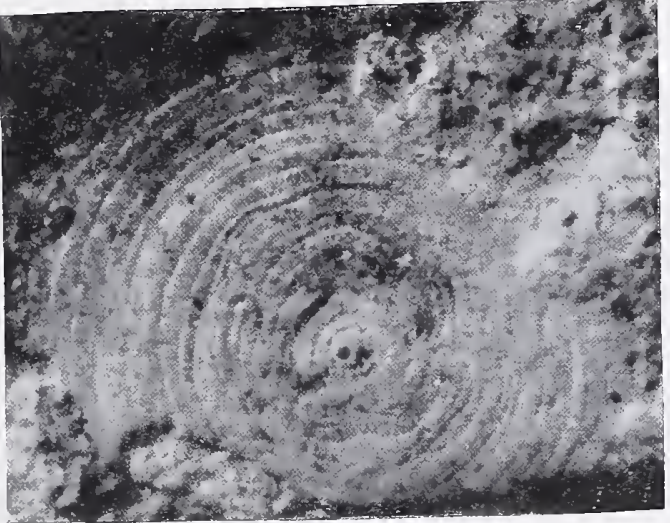

4
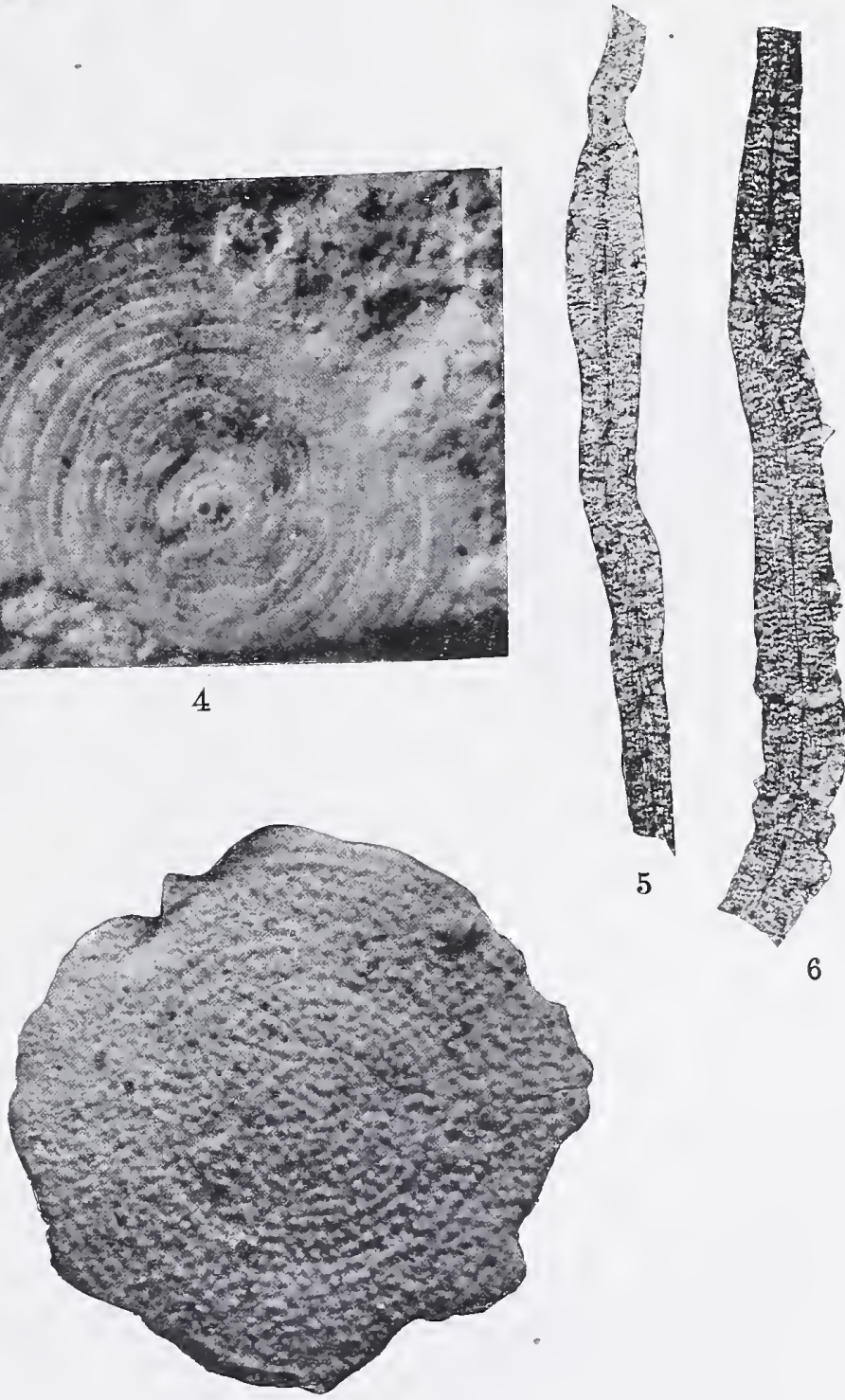

7

$131049^{\circ}-20-5$

AMERICAN SPECIES OF ORTHOPHRAGMINA. 


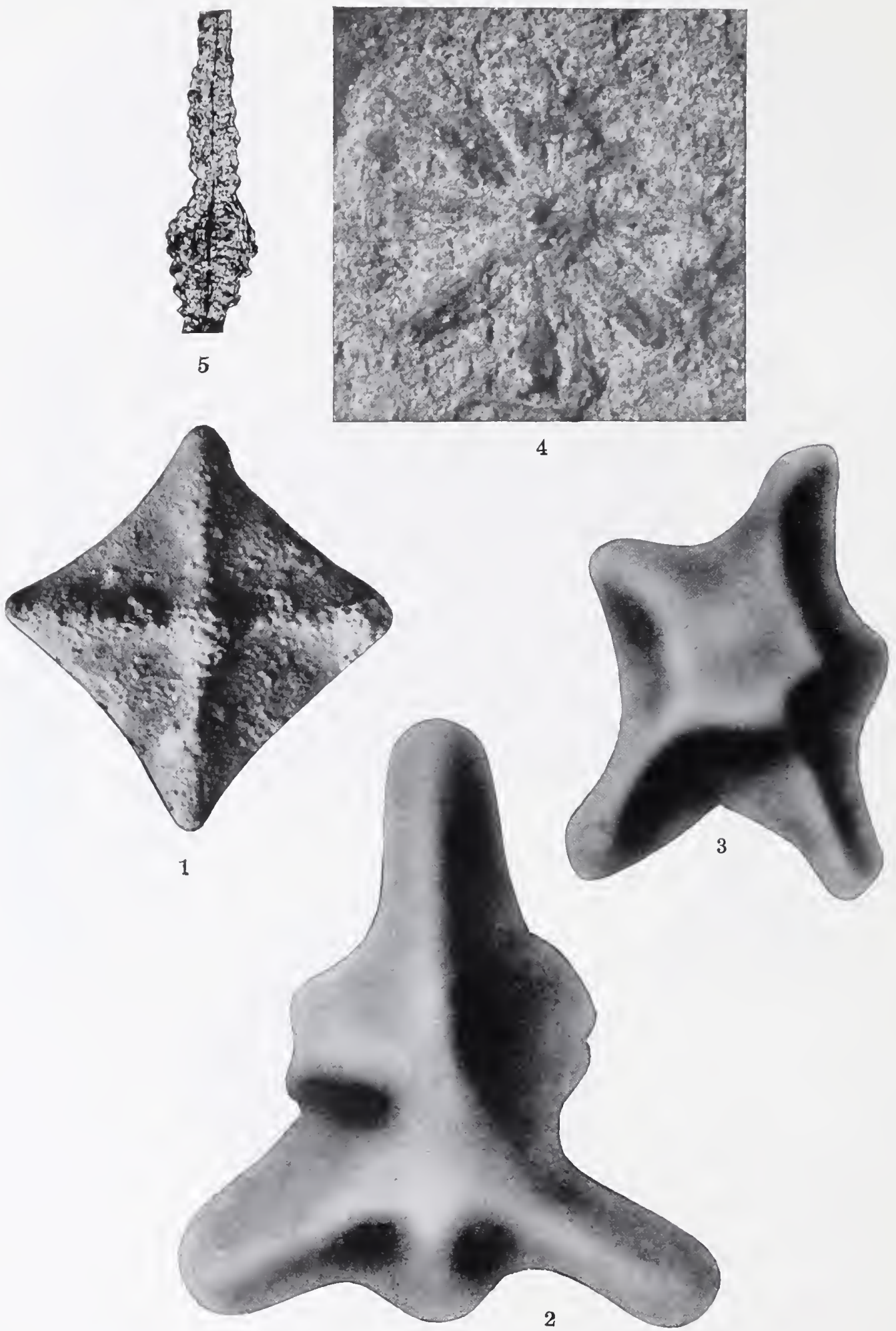

AMERICAN SPECIES OF ORTHOPIIRAGMINA. 


\section{PLATE X.}

Orthophragmina georgiana Cushman (p. 45).

Figure 1. Surface view of type specimen, $\times 8$. Ocala limestone of Georgia (U. S. G. S. station 7318 ).

Orthophragmina subtaramellei Cushman (p. 45).

Figures 2, 3. Surface views $\times 20$, Boston manganese mine, Santiago Province, Cuba (U. S. G. S. station 6120).

Orthophragmina antillea Cushman (p. 46).

FIgUre 4. Surface view of type specimen, $\times 5$. St. Jean Bay, St. Bartholomew, Leeward Islands (U. S. G. S. station 6895).

Figure 5. Portion of vertical section, $\times 20$. Same locality as figure 4 . 


\section{PIATE XI.}

Orthophragmina mariannensis Cushman (p. 46).

Figure 1. Surface view of specimen, $X 4$. Ocala limestone of Florida (U. S. G. S. station 6768).

Orthophragmina mariannensis var. papillata Cushman (p. 47).

Figure 2. Surface view of specimen, $\times 6$. Ocala limestone of Georgia (U. S. G. S. station 7126).

Orthophragmina vaughani Cushman (p. 47).

Figure 3. Surface view of type specimen, $\times 8$. Ocala limestone of Georgia (U. S. G. S. station 3387). Orthophragmina americana Cushman (p. 47).

Figure 4. Surface view of type specimen, $X 4$. Ocala limestone of Florida (U. S. G. S. station 676S). 54 


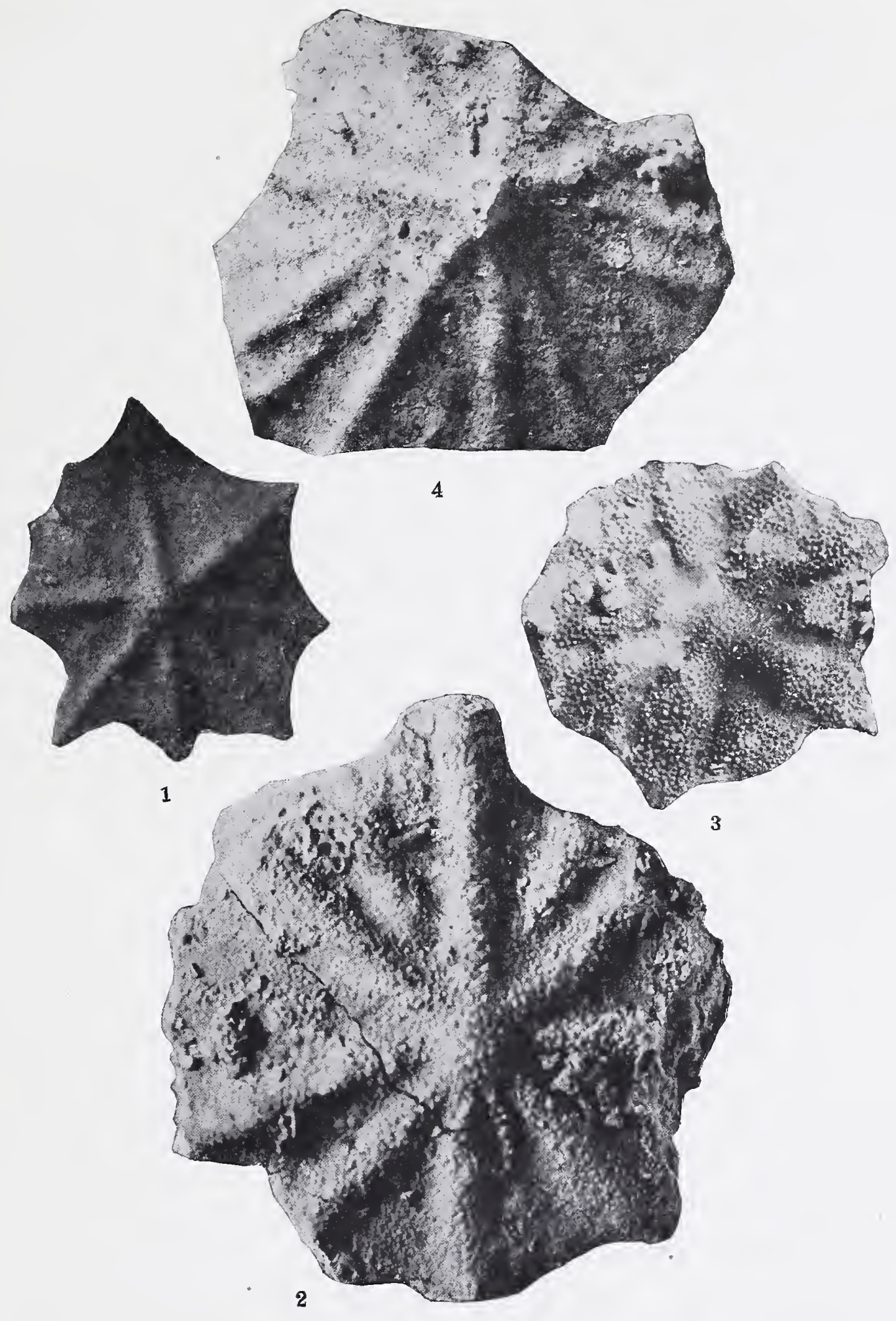

AMERICAN SPECIES OF ORTHOPHRAGMINA. 
AMERICAN SPECIES OF LEPIDOCYCLINA.

Although numerous species and varieties of orbitoid Foraminifera from many parts of the world have been described, almost nothing has been published on the American species. In 1833 Morton ${ }^{1}$ described Nummulites mantelli, which was later taken by Gümbel in 1S6S as the type of a subgenus of Orbitoides that he named Lepidocyclina. This is now recognized as a genus, and L. mantelli (Morton) is the type species. In 1865 Conrad ${ }^{2}$ published a brief description of Orbitolites supera, which may now be known as Lepidocyclina supera (Conrad). These are the only species of orbitoid Foraminifera from the Coastal Plain region of the United States of which descriptions had been published prior to the publication of my paper on orbitoid Foraminifera of the genus Orthophragmina from Georgia and Florida, ${ }^{3}$ in 1917. Two species of Lepidocyclina from Panama (L. canellei and L. chaeri) were described by Lemoine and $R$. Douvillé $^{4}$ in 1904 , and H. Douvillé ${ }^{5}$ has recently described two species from Trinidad (L. pustulosa and L. tobleri).

Several works refer to American species under names which were erroneously applied to them, but most of these species do not even belong to the genus Lepidocyclina.

From the collections of the United States Geological Survey, especially those obtained by 'T. Wayland Vaughan and C. Wythe Cooke, there has been placed in my hands a mass of material representing the Eocene and Oligocene deposits of the Atlantic and Gulf Coastal Plain of the United States. In addition I have examined collections from Panama obtained by Mr. Vaughan and the geologist of the Panama Canal Commission, Donald F. MacDonald; from Antigua and St. Bartholomew, by Mr. Vaughan; from Cuba, by Messrs. Vaughan, Darton, Hayes, Spencer, and Meinzer; and from Mexico, by E. T. Dumble, geologist for the Southern Pacific Railroad. These collections, with miscellaneous lots from many other localities, contain a great many specimens of Lepidocyclina and are representative of many regions.

\footnotetext{
${ }^{1}$ Am. Jour. Sci., vol. 23, p. 291, pl. 5, fig. 9, 1833.

${ }^{2}$ Acad. Nat. Sci. Philadelphia Proc., No. 2, p. 74, 1865.

${ }^{3}$ Cushman, J. A., U. S. Geol. Survey Prof.Paper 108, pp. 115-124, pls. 40-44, 1917.

* Soc. géol. France, Paléontologie, Mém. 32, 1904.

6 Compt. Rend., 1917, pp. 843, 844, figs. 1-6.
}

A study of the collections shows that this general region contains a few widely distributed species which have already been found elsewhere, but by far the largest number of the species are undescribed, although some of them show relationships with species from other areas.

As a rule the species seem to have a very short rertical range and may therefore be used as index fossils for those formations in which they occur. The stratigraphy of the Coastal Plain region is now well coordinated, and it is possible to place the species very definitely, but in many other regions the detailed stratigraphy is not fully known, and comparisons are more difficult.

It is evident that in America Lepidocyclina is found both in the upper Eocene and in the lower and middle Oligocene as now understood. The detailed structure and the bioogic relations of the various species are interesting but are reserved for discussion in a future paper.

In general the habitat in which Lepidocyclina was first developed was in fairly quiet waters of a tropical temperature and probably at depths less than 25 fathoms. The associated genera, Operculina, Heterostegina, Carpenteria, and Gypsina, are, so far as their living representatives show, characteristic of such conditions.

As an aid in understanding the structure of Lepidocyclina for one not used to the terminology the accompanying diagrammatic figure of a vertical section has been introduced. The structure involves two distinct masses of calcareous material - that belonging to or originating from the median layer (stippled in the figure) and that belonging to the lateral layers (solid black in the figure). In the central region are the embryonic chambers, one or more, in the megalospheric form of any species usually large and rounded. Surrounding these, usually in a single plane, are numerous equatorial chambers, shown in the diagram as two series on opposite sides of the embryonic chambers increasing in height from the center toward the periphery. Above and below this band of equatorial chambers, and usually corering them except near the periphery, are the numerous lateral chambers, usually seen in vertical section piled one above another in rertical col- 
umns. In many species pillars are developed, usually solicl masses of calcareous material originating at the wall of the horizontal serjes and extending to or toward the surface of the test. These pillar's in some species rise above the surface and form the pustules or papillae of the surface ornamentation.

1 horizontal section such as shown in Plate XXIX, fignre 3 , is made at right angles to that shown in the diagram and passes through the plane of the equatorial chambers. Such a section shows that the equatorial chambers in this genus have typically a hexagonal form, although this may often be modified to an ogival form or in rertain species even to the
Undombtedly other species will be found when more geologic work is done in the different areas, and probably more careful detailed collecting will show that sperial rarietal forms of the various species occur at different horizons. Most of the species represented in the collections now avalable are here described, so that the information thus far ohtained may be used as a basis for further work and in helping to solve problems of stratigraphic correlation. It is hoped that this paper may be followed loy a paper giving some of the interesting facts of structure and biologic relations that are shown by the speries of this genus.

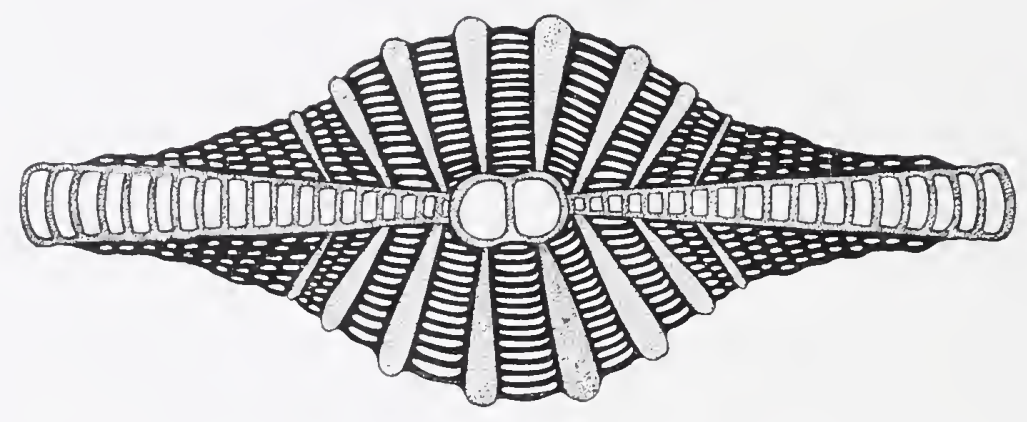

Figure 3.-Diagrammatic rertical seetion of Lepidocyclina. Naterial of the wall of the embryonic chambers (the two large ones in the center), of the equatorial chambers (the two central bands passing to right and left), and the pillars in light stipple. Walls of the lateral chambers in solid black. Areas of the chamber spaces white.

rhomboid. Thus a horizontal section will discriminate this genus from the other orbitoid genus, Orthophragmina, with which it ocrurs, as in Orthophragmina the equatorial chambers are elongate and rectangular.

Of the Coastal Plain species the following seem to be eharacteristic of certain formations:

Chattahoochee formation (midlle Oligocene):

L. chattahoorheensis.

Byram calcareous marl (lower Oligocene):

L. supera.

Marianna limestone ( Iower Oligocene):

i. Inantelli.

Ocala limestone (upper Eocene):

Especially in Florida:

1. ocalana.

1. ocalana var. sublecorata.

l. floridana.

I. pseudocarinata.

I. pseudomarginata.

1. attenuatid.

1. fragilis.

L. cookei.

Especially in Georgia :

I. georgiana.

Jackson formation (upper Eocene):

Especially in Louisiana:

L. mortoni.
By means of the subjoined key it may be possible to identify American material that is sufficicntly well preserved.

Key to the Imerican speeies of Lepidocyclina.

Test of two distinct portions, a central thickened portion and a very thin peripheral portion:

central portion cleeply pitted:

Pits few and large, test strongly sellaeform, diameter 15 to 18 millimeters....... L. favosa.

Pits numerous and small, test slightly sellaeform, diumeter 15 to 25 millimeters.

..................... chattahoocheönsis.

Central portion smooth.......... L. pseudocarinata.

Central portion papillate:

Papillae fine, central area small..L. attenuata.

Papillae coarse, central area large....L. cookei.

Test comparatively thin with small central umbo:

Test of medium size, flat, diameter 20 to 35 millimeters:

Surface smooth.................. mantelli.

Surface papillate.................... L. hilli.

Test large, diameter 50 to 100 millimeters:

Tmbo small, surface slightly papillate, lateral chambers few, only 6 in a vertical column pillars small and scattered.......L. undulata. Umbo prominent:

Surface papillate, pillars numerous, lateral chambers 20 or more in a vertical column ........................ georgiana. 
Test comparatively thin with small central umbo-Con. Test large, diameter 50 to 100 millimeters-Contd.

Umbo prominent-Continued.

Surface reticulate or smooth, pillars few lateral chambers 7 to 10 in a vertical column ....................... gigas.

Test small, diameter 8 to 20 millimeters:

Pillars absent, lateral chambers few, 4 to 6 . ............................ fragitis.

Pillars present, lateral chambers numerous:

Embryonic chambers subequal, equatorial chambers hexagonal............ chaperi.

Embryonic chambers very unequal, equatorial chambers rhomboid ...... vaughani.

Test thickened at center, not distinctly umbonate but gradually thinning toward the periphery:

Test very strongly sellaeform:

Pillars numerous, test small, diameter usually

4 to 8 millimeters................ L. floridana.

Pillars few, test small, diameter usually 8 to 12

millimeters........................ perundosa.

Pillars absent, test larger, diameter usually 25 millimeters or more................L. undosa.

Test not greatly thickened, slightly sellaeform:

Centrally papillate, pillars largely in the central region:

Diameter 25 to 35 millimeters

Diameter 12 to 15 millimeters

..................... pseudomarginata.

Surface finely papillate throughout:

Lateral chambers 10 to $12 \ldots \ldots$...L. supera.

Lateral chambers 7 to 8 ........... mortoni.

Surface smooth or reticulate, lateral chambers

15 to $20 \ldots . . . . . . . . . . . . . . . . . . . .$. ocalana.

Test not sellaeform, lenticular:

Diameter 20 to 30 millimeters, center pustulate, pillars numerous, increasing gradually in diameter to the surface................ . subrautinii.

Diameter 10 to 15 millimeters, center pustulate:

Pillars numerous, increasing to full diameter in first third of length, then uniform to the surface, not thickened at periphery ......................... L. marginata.

Periphery much thickened....L. duplicata.

Diameter less than 10 millimeters:

Diameter 8 to 9 millimeters, chamber walls very thick..................... crassata.

Chamber walls thin, pillars absent:

Surface smooth or reticulate, lateral chambers 10 to $12 . . . . . . . .$. . canellei.

Surface centrally pustulate, lateral chambers 6 to 10 ............. L. sumatrensis.

Chamber walls thin, pillars present:

Center pustulate, reticulate between, diameter 2 to 5 millimeters, embryonic chambers reniform, lateral chambers $10 \ldots . . . . . . . . . . . . .$. . morgani.

Center pustulate, smooth between, diameter 5 to 7 millimeters, embryonic chambers reniform.....L. macdonaldi.

Center pustulate, embryonic chambers several, unequal......... panamensis.

Center papillate, lateral chambers 6 to 7
Lepidocyclina mantelli (Morton) Gümbel.

Plates XII-XIV.

Nummulites mantelli Morton, Am. Jour. Sci., vol. 23, p. 291, pl. 5, fig. 9, 1833; Synopsis of organic remains of the Cretaceous group, p. 45, pl. 5, fig. 9, 1834.

Orbitoides (Lepidocyclina) mantelli (Morton) Gümbel, K.-bayer Akad. Wiss. Abh., vol. 10, p. 718, 1868 (1870).

Orbitoides mantelli D'Orbigny, in Lyell, Geol. Soc. London Quart. Jour., vol. 4, p. 11, 1847 (1848); Prodome de paléontologie, vol. 2, p. 406, No. 1296, 1850.

Carpenter, Geol. Soc. London Quart. Jour., vol. 6, p. 32, pl. 6, figs. 20, 21, 31, 1850.

Carpenter, Parker, and Jones, Introduction to the study of the Foraminifera, pp. 298, 300, pl. 20, figs. $5,6,8,11,1862$.

Bütschli, in Bronn, Klassen und Ordnungen des Thier-Reichs, p. 215, pl. 12, fig. 22, 1880; in Steinmann, Elemente de Paläontologie, rol. 1, p. 36, fig. K, 1888.

De Gregorio, Annales géol. paléont., vol. S, p. 261, pl. 46 , figs. 16, 17, 1890.

Lepidocyclina mantelli Lemoine and R. Douvillé, Soc. géol. France Mém., Paléontologie, No. 32, p. 10 , pl. 1, fig. 4; pl. 2, fig. 18; pl. 3, figs. 7, 12, 1904.

Orbitoides mantelli mut. umbrellopsis De Gregorio, Annales géol. páleont., vol. 8, p. 262, pl.46, figs. 21-26, 1890.

Test thin, flattened, circular, often slightly undulate; adults from 25 to 35 millimeters in diameter, in exceptional specimens 41 millimeters; central region slightly protuberant on both sides of the test, the umbo thus formed being limited to the central portion and only 2 to 3 millimeters in diameter; surface smooth in well-preserved specimens, or slightly pustulate, owing to the irregular elevation of the outer walls of adjacent lateral chambers; in eroded specimens irregularly scrobiculate; young specimens with the central umbonal protuberance more marked than in adults.

The horizontal section (Pl. XIII) shows the irregular hexagonal equatorial chambers, the annuli very irregular in width; lateral chambers also generally hexagonal or at least polygonal, without pillars; embryonic chambers of the megalospheric form, two subequal, the dividing wall straight.

Vertical sections (Pl. XII, figs. 4, 5) show the band of. equatorial chambers increasing somewhat in height toward the periphery, where they make up almost the entire thickness of the test; the lateral chambers broad and low, several times as broad as high, overlapping instead of in regular vertical columns, and thus showing the absence of pillars; embryonic chambers of the megalospheric form, 
showing their subequal form and straight dividing wall.

Morton's Nummulites mantelli was taken by Gümbel as the type species of his genus Lepidocyclina, and it is therefore especially important to fix this species very definitely. Fortunately, as already noted, although no type specimen is available, the published data, though meager, are nevertheless sufficient. Morton's description," "Flattened, thin, becoming sharp at the edge, and having a central pustuloid elevation, diameter from half an inch to an inch and a half," combined with the figure, is enough to determine this species, which is "innumerable in the whitish loosegrained limestone near Claiborne, Ala."

The diameter given by Morton, half an inch to an inch and a half, and by Lemoine and R. Douvillé, 25 to 35 millimeters, gives the maximum size almost exactly. In fact, where there is an abundance of the material it is most striking to see the very slight range of diameter of well-dereloped specimens away from 35 millimeters. As may be supposed, from what is known of the life history of recent Foraminifera, the great mass of adult fossil Foraminifera represent not animals that have died from usual causes but individuals that have diviced their cell contents in the reproductive process and left the test empty. This process, taking place at a certain stage in the life history of the individual, leares an abundance of empty tests of adults and comparatively few tests of young individuals in the same bottom sample, and therefore accounts for the great abundance of individual tests of the maximum adult size.

In 1890 De Gregorio " gave four "mutations" of "Orbitoides mantelli." His figures 16 and 17 are copied from the originals of Morton, and of the other illustrations, figures 21 to 26 , which show the "mutation" (text) or "var." (explanation of plate), called by De Gregorio "umbrellopsis," represent the typical L. mantelli. Figures 21 to 23 are not well characterized but are sufficiently so, and figures 24 to 26 are very typical of the early stages of $L$. mantelli. The description, "Papyracea, dilatata, exilis, in medio utroque latere vix subtuberculata," certainly adds nothing to dis-

\footnotetext{
1 Am Jour. Sci., vol. 23, p. 291, 1833.

Annales géol. paléont., vol. 8, pp. 261, 262, pl. 46, figs. 16-32, 1890.
}

tinguish this from typical $L$. mantelli. Moreover, De Gregorio leaves no form for the typical, dividing all his material into the four "mutations." Therefore it seerns reasonably certain that var. umbrellopsis De Gregorio is but a synonym. Of the other three "mutations," the figures of which are evidently much enlarged from small specimens, little need be said here except that they evidently are neither $L$. mantelli nor forms of that species.

As is shown by the records, $L$. mantelli is characteristic of certain definite horizons near the base of the Oligocene in Alabama, parts of Mississippi, and northwestern Florida. From all the material examined it seems to occur usually alone, without other species of its group, a peculiarity that distinguishes it from certain species of similar size in the upper Eocene.

It has been suggested that the absence of pillars in this and other species is evidence of a primitive character, but this I do not think necessarily true. $L$. mantelli occurs geologically later than other species that show very strongly developed pillars, and, as noted in the description of $L$. georgiana, a condition lacking pillars may follow an early development in which pillars were characteristic. From this evidence, and the fact that the umbo in the adult shows a tendency to flatten, it would seem that $L$. mantelli may be really a senescent species rather than a primitive one. In every lot of material in which the species occurs in considerable numbers a very few specimens are found which exceed the normal maximum diameter of 35 millimeters. These range from 38 to 41 millimeters, and their rarity, together with their larger size, seems to indicate that they are the microspheric form of the species. The embryonic chambers are not shown clearly, although present in the larger specimens (Pl. XIII; Pl. XIV, fig. 1). Lemoine and R. Douvillé record the occurrence of both microspheric and megalospheric forms but give no data as to their relative size.

In the American literature the name "Orbitoides mantelli" has covered many things, and it is evident from the material in various collections that the name has been used very loosely. The list of stations given here will serve to check those references in the literature in which they are montioned. References to other sta- 
tions from which I have not seen material should be checked from collected material if it is extant.

H. Douville ${ }^{1}$ figures sections of $L$. mantelli that appear to show very small pillars near the equatorial chambers, which become obsolete very early in their development. Such a structure would tend to show the senescent rather than primitive character of this species.

Instead of $L$. mantelli initiating the appearance of Lepidocyclina in America in the upper Eocene, as stated by Douvillé, the species comes relatively high in the series and is a characteristic or index fossil of the Marianna limestone, which in the areas where it is most definitely developed is the middle formation of the Vicksburg group of the lower Oligocene, as shown by Cooke ${ }^{2}$ in his correlation table.

L. mantelli, like most of the other species of the genus, was not very long lived, and is confined in great numbers to a narrow horizon.

$A$ few of the following records may need revision, as the material is poor, but most of them are well characterized.

In his original description Morton gives the following sentence: "Innumerable in the whitish loose-grained limestone near Claiborne, Ala." Although Morton's type specimen does not seem to be extant, it is very easy to determine from his very short description and the rather crude figure coupled with the above sentence just what $L$. mantelli is. Various other species have been referred to it from time to time, and these references need correction. Typical $L$. mantelli has been obtained at the following stations from which I have seen material:

298. Marianna limestone, St. Stephens Bluff, Tombigbee River, Ala.; L. C. Johnson, collector.

301. Marianna limestone (?), Gainestown, Clarke County, Ala.; L. C. Johnson, collector.

306. Marianna limestone (?), Feagin, Covington County, Conecuh River, Ala.; L. C. Johnson, collector.

2397. Marianna limestone, near residence of Bush Slaughter, 7 miles southwest of Claiborne, 2 miles east of Howards Landing, Monroe County, Ala.; Frank Burns, collector.

2956. Marianna limestone (?) "Orbitoides papyraceus," 2 miles southwest of Whatley Station, Clarke County, Ala.; Frank Burns, collector, 1897.

3296. Marianna limestone, north side of Salt Mountain, 5 miles south of Jackson, Clarke County, Ala. (below coral-reef horizon); T. W. Vaughan, collector, 1898.

1 Compt. Rend., 1918, p. 263.

2 Cooke, C. W., Washington Acad. Sci. Jour., vol. 8, p. 187, 1918.
5609. Marianna limestone, St. Stephens Bluff, Tombigbee River, Ala.; T. W. Vaughan, collector, 1908.

5619. Oligocene (Vicksburg group), 2 miles west of Nero, Monroe County, 5 miles north of Mero's (Blackshire Headquarters), south bank of Lovetts Creek, Ala.; G. C. Matson, collector, 1910.

6702. Marianna limestone, hillside a quarter of a mile east of Alabama, Tennessee \& Northern Railroad, $2 \frac{1}{2}$ miles north of Millry, Washington County, Ala.; C. W. Cooke, collector.

6710. Marianna limestone, St. Stephens Bluff, Tombigbee River, Ala.; bed 7 of section, soft white "chimney rock"; C. W. Cooke, collector.

6711. Marianna limestone, St. Stephens Bluff, Ala.; bed 4 of section; C. W. Cooke, collector.

6716. Marianna limestone, ravine east of road about three-quarters of a mile north of Monroeville, Monroe County, Ala.; C. W. Cooke, collector.

6717. Marianna limestone, 1 mile north of Monroeville, Monroe County, Ala.; C. W. Cooke, collector. 6721. Marianna limestone, gully south of station at Drewry, Monroe County, Ala.; C. W. Cooke, collector. 6728. Marianna limestone, road from Perdue Hill to Claiborne, Monroe County, Ala.; exposed in gully west of road, bed 1 of section (bottom 250 feet above Alabama River); C. W. Cooke, collector.

6729. Marianna limestone, road from Perdue Hill to Claiborne, Monroe County, Ala.; bed 3 of section; C. W. Cooke, collector.

6732. Marianna limestone, Murder Creek at bridge east of Castleberry, Conecuh County, Ala.; bed 1 of section; C. W. Cooke, collector.

6733. Marianna limestone, bed 2 of same section as 6732 . 6748. Marianna limestone, west bank of Conecuh River at bend about a quarter of a mile below mouth of Sepulga River, Escambia County, Ala.; C. W. Cooke, collector. 6750. Marianna limestone, Rock House Bluff, right bank of Conecuh River, near line between secs. 28 and 29, T. 3 N., R. 14 E., Covington County, Ala.; talus from upper bed; C. W. Cooke, collector.

7164. Glendon limestone member of Marianna limestone, Jackson-Rockville road, 200 yards north of Salt Creek, Clarke County, Ala.; bed 3 of section; C. W. Cooke, collector.

7208. Marianna limestone, Whitsett's quarry, about 3 miles south of Cullomburg, Ala.; beds 2-4 of section; C. W. Cooke and W. C. Mansfield, collectors.

7238. Marianna limestone, Murder Creek at bridge east of Castleberry, Ala.; bottom of bed 1 of section; C. W. Cooke and W. C. Mansfield, collectors.

The specimens from the following stations seem to be L. mantelli:

119. Tertiary, Bogue Homo rocks and prairies, Jasper County, Miss.; L. C. Johnson, collector.

259. Vicksburg group, about middle beds of the bluff in hard marlstone, Vicksburg, Miss.; Burns, collector. 334. Vicksburg 'group, south side of Eucutta Creek, Wayne County, Miss., on a high hill 5 miles west of Shubuta, Clarke County, Miss.

337. Vicksburg group, Heidelberg, Jasper County, Miss., sec. 25 ; L. C. Johnson, collector.

2636. Oligocene, Wayne County, Miss.; Burns, collector. 
4331. Two miles above Isyram, on Pearl River, Miss, ledge about midcllo of the formation; A. F. ('risler. collector.

6545. Marianna limestone, rock quarry 4 miles east of Brandon, Rankin County, Miss, sonth of Rankin on Mlabama of Vicksburo Railway; T. IT. Taughan, collector. 6641. Marianna limestone, Goodwater Creok, 3 miles soutlieast of Tossburg, Miss.; C. IV. Cooke, collector.

6645. Marianna limestone, roadside on hill in sec. 2, $1 \frac{1}{2}$ miles south-southeast of Heidelberg, Jasper County, Miss ; beds $\mathbf{1 - 5}$ of section; $C$. W. Cooke, collector.

6767. Marianna limestone, west side of Marianna, Fla.

Lepidocyclina hilli Cushman, 11. sp.

Plate $\mathrm{XV}$, figure 1; Plate XVI, figure 2.

Test circular, flat, thin: centrai portion elevated slightly more on one side than on the other; gradually sloping from the thickened center to the peripheral portion, which is flat; umbonal region in the very center strongly papillate, with a few large papillae about which may be as many as eight of the lateral chambers, forming a concentric series of reticulations; papillae smaller as the distance from the eenter of the test increases.

A vertical section near the edge shows the equatorial chambers about three times as high as loroad; lateral chambers numerous, very low and broarl, in rertical columns.

Type specimen (U. S. N. M. No. 135220) from the Guallava sandstone of Costa Rica, collected by R. T. Hill. Specimens from U. S. G. S. station 6722 (Ocala limestone, old quarry three-fourthsmile west and three-lourths mile north from Monroeville, Ala.), collected by C. W. Cooke, seem to be close to this species.

In its general form $L$. hilli strongly resembles L. mantelli (Morton), but the slope from the central umbo is carried out over a wider area and the large papillae of the center with the smaller ones over a large part of the surface will at once distinguish it from that species. The umbonal region with the depressed concentric series of reticulations about the large papillae suggests $L$. morgani, which is in other respects very different.

\section{Lepidocyclina undulata Cushman.}

Plate XV, figures 2-5.

Lepidoeyclina undulata Cushman, Carnegie Inst. Washington Pub. 291, p. 65, pl. 3, figs. 1a. 2, 8, 9; pl. 15, fig. 5, 1919.

'Test large, slightly papillate, lenticular; the umbonate region searcely if at all raised; whole test undulate or saddle-shaped, often hent nearly double.

Vertical sections (Pl. XY, fig. 4) of this species show pillars very constant but of small diameter scattered throughout the central half of the test and a few toward the peripheral portion; equatorial chambers fairly high and with a series of 6 to 8 rather large perforations in the peripheral wall; lateral chambers thickwalled and rather large, comparatively few, usually not more than six in a rertical column.

Equatorial chambers (Pl. XV, figs. 2, 3) hexagonal in horizontal section.

Diameter in the largest specimens apparently exceeding 100 millimeters when complete.

The type locality for this species is $\mathrm{C}$. S. G. S. station 6863, Iligh Point, Antigua, Leeward Islands; collected by T. W. Vaughan. Specimens were abundant at this station. Other material from Antigua apparently referable to this species was obtained at stations 6558, Wetherell Point; 6874, Blizzards Mill; (?) 6850 , west side of Otto's estate, west side of Golden Grove road; 6ss1, bluff on north side of Willoughby Bay; and 6942, boulders on south side of Monks Hill, Falmouth.

This seems to be the largest known species of Lepidocyclina, being larger than L. elepthantina. The material here figured from station 6881 (Pl. XV, fig. 5) is for the most part composed of smaller specimens which may possibly belong to another species but which have the saddle-shaped form of the larger specimens. The specimens make up a large proportion of the mass of the rock.

Lepidocyclina georgiana Cushman, n. sp.

Plate XVI, figure 1; Plate XVII, figures 1-3; Plate XVIII, figures 1, 2.

Test large, flattened, or slightly undulate or sellaeform; largest specimens measuring 70 millimeters in diameter, more general run of specimens 25 to 50 millimeters; central region in young and medium-sized specimens prominently umbonate, in the largest ones much less so; surface in the earlier stages serobieulate toward the margins, becoming rather strongly papillate toward the center and especially on the umbonal region; umbo small, usually less than 5 millimeters in diameter.

The horizontal section (Pl. XVIII, fig. 1) shows the chambers of the equatorial band 
either hexagonal or with the peripheral angle changed to an even convex curre; walls of medium thickness; annuli inregular.

In rertical section (Pl. XVI, fig. 1) the equatorial chambers increase in height toward the periphery, where they are at least four times as liigh as their diameter; lateral chambers compressed, broad and low in the central region with as many as 20 chambers in each column but soon diminishing in number toward the periphery of the test, the outer third of the region with but one to three chambers superimposed, the thin test being made up largely of the high equatorial chambers; pillars mostly in the umbonal region, thence gradually decreasing in number toward the periphery of the test; in section, narrow wedge-shaped, the distal end broadest and somewhat convex, gradually tapering toward the proximal end, usually showing longitudinal laminations in section, in some specimens with the greatest width in the central region and thinning again toward the periphery.

Type specimen from U. S. G. S. station 7097, Ocala limestone, on the east bank of Flint River above the old factory at bend three-quarters of a mile northeast of the Atlantic Coast Line Railway station at Bainbridge, Ga.; C. W. Cooke and W. C. Mansfield, collectors. It has also been collected in the Ocala limestone at the following stations:

3387. Red Bluff, on Flint River 7 miles above Bainbridge, Ga.; T. W. Vaughan, collector.

7099. East bank of Flint River about half a mile above Red Bluff, Decatur County, Ga.; C. W. Cooke, collector. 8259. About 6 miles southeast of Campbellton and 12 miles northwest of Marianna, on road to Cottonwood, Ala., half a mile from its intersection with the Marianna-Campbellton road, Jackson County, Fla.; C. W. Cooke, collector.

At all four of these stations $L$. georgiana is accompanied by Orthophragmina georgiana Cushman. At station 8259 a single specimen was noted, not well characterized but referred here provisionally.

Specimens of $L$. georgiana oceur at the following stations:

3382. Hales Landing on Flint River, 7 miles below Bainbridge, Ga.; T. W. Vaughan, collector.

3383. Blue Springs, Ga.; exterior molds of specimens apparently $L$. georgiana; T. W. Vaughan, collector.

3390. Below Plant System wharf, Bainbridge, Ga., T. W. Vaughan, collector.
3397. Back of old factory about $1 \frac{1}{2}$ miles above Bainbridge, Ga. (same locality as station 7097); T. W. Vaughan, collector.

4974. West side of St. Andrews Bay Road, southwest of Chipley, Fla.; G. C. Matson, collector.

7082. Irales Landing, west bank of Flint River 7 miles southwest of Bainbridge, Ga.; T. W. Vaughan, C. W. Cooke, and W. C. Mansfield, collectors.

7126. East bank of Flint River at Dry Bread Shoals, Mitchell County, Ga., $8 \frac{1}{2}$ or 9 miles below Newton, from lumps blasted from the channel; C. W. Cooke, collector.

7130. East bank of Flint River 6 miles above Bainbridge, Ga.; C. W. Cooke and J. E. Brantly, collectors.

7149. East bank of Flint River below wagon bridge at Bainbridge, Ga.; W. C. Mansfield, collector.

8331. Old gristmill on Aycock Creek, 100 yards above crossing of Twilight Road, 3 miles southwest of Boykin station, Miller County, Ga.; C. W. Cooke, collector.

In the region about Marianna, Fla., $L$. georgiana occurs at the following stations:

7194. Ocala limestone, soft cream-colored limestone, bed 4 of section, at mouth of cavern 200 yards southwest of wagon bridge over Chipola River east of Marianna, Fla.; C. W. Cooke and W. C. Mansfield, collectors. In this part of the section it occurs with other typical Ocala species of Lepidocyclina.

7195. Bed 5 of same section, white limestone, apparently has this species.

7199. Same locality, contact of beds 4 and 5; W. C. Mansfield, collector.

Specimens from station 7242, bottom of bed 5 of section on west bank of Chipola River at wagon bridge half a mile east of Marianna, Fla., collected by W. C. Mansfield, are apparently L. georgiana but are not sufficiently well characterized to make the determination absolute. An interesting assemblage, among which are specimens that may be referred to L. georgiana, was found at station 7672 , on Chipola River at Louisville \& Nashville Railroad, three quarters of a mile east of Marianna, Fla, by C. W. Cooke.

This is the large species referred to in the literature on Georgia, especially as Orbitoides papyracea, mainly on earlier identifications of R. M. Bagg, jr. The O. papyracea of later authors following Gümbel and Boubée is really an Orthophragmina, for which the name $O$. pratii Michelin must be used according to Schlumberger. Our material is Lepidocyclina, and the name $O_{\varepsilon}$. papyracea as used in the literature in references to the following places should be L. georgiana Cushman: Albany, Ga., west end of wagon bridge ${ }^{1}$; limestone at Red Bluff,

i Vaughan, T. W., in Veatch, Otto, and Stephenson, L. W., Georgia Geol. Survey Bull. 26, p. 317, 1911. 
7 miles above Bainbridge, Ga. ${ }^{1}$; bluff on east side of Flint River back of old factory about 2 miles above Bainbridge, Ga. ${ }^{2}$, Hales Landing, on Flint Rirer 7 miles below Bainbridge, Ga. ${ }^{2}$ I have seen and checked material from all these localities.

The species is a very large one in at least some of its inclividuals, but the range in size is very considerable, and it may be very likely that the largest specimens are the microspheric form of the species and the smaller ones the megalospheric. The material is not sufficiently well preserved to permit a study of the embryonic chambers in detail.

There is evidently a progressive development in form of the test and character of the ornamentation of the surface. In the smaller, younger specimens the umbonal portion is strongly raised and the whole test is prominently papillate, although the umbonal portion shows the papillae most prominently. In older specimens the papillae are largely limited to the central region and the umbonal region of the test is not nearly so much raised in comparison as in the young. This character is similar to that seen in the young of $L$. mantelli and already noted.

At the following Georgia stations $T$. $T$. Vaughan collected molds of the exterior, probably of $L$. georgiana: 3618 , west end of wagon bridge, Albany; 3624, 1 mile east of Americus; 3625, 2 miles east of Americus. A single specimen showing equatorial chambers of a Lepidocyclina, which may be L. georgiana, was obtained at Saffold, Early County, Ga. The rock is very hard and filled with pits, indicating possibly in part a small nummulite. This material is similar to that obtained at station 7094, on the west bank of Flint Rirer at the Atlantic Coast Line Railroad bridge at Bainbridge, which also las the same character.

A specimen from station 4959, Rich Hill, Crawford County, Ga., collected by L. IT. Stephenson, may be the young of this species.

L. georgiana is characteristic of the Ocala limestone occurring at many stations with several species of Orthophragmina.

The following additional stations in Georgia have furnished material which, though not inwardly well preserved, probably should be referred to L. georgiana:

1 Vaughan, T. W., in Veatch, Otto, and Stephenson, L. W., Georgia Geol. Survey Bull. 26, pp. 320, 329, 1911.

Idem, p. 332 .
3293. Left bank of Flint River at Bainloridge, Decatur County; $\Lambda$. II. Brooks, collector.

3380. Lase of bluff at Little Itorseshoe Dend, just below the moutl of Blue or Russell Spring, Flint River, Decatur County; T. W. Vaughan, collector.

3768. Twelve miles north of Bainbridge and 3 miles west of Flint River; S. W. Mcrallie, collector.

6110. Steamboat landing, Bainbridge.

6159. Red Bluff, Flint River; L. W. Stephenson, collector.

6160. Flint River, north of Blue Spring, 4 miles below Bainbridge, Decatur County; L. W. Stephenson, collector. 6161. Flint River at Bainbridge; L. IV. Stephenson, collector.

7082. IIales Landing, west bank of Flint River, 7 miles soutluwest of Bainbridge; T. W. Vaughan, C. W. Cooke, ancl IT. C. Mansfield, collectors.

7095. Red Bluff, Flint River, 7 miles above Bainbridge; C. W. Cooke, collector.

7106. Flint River at mouth of Spring Creek, Sumter County, 2 miles above Seaboard Air Line Railway bridge; C. W. Cooke and J. E. Brantly, collectors.

7127. East bank of Flint River in Mitchell rounty, a quarter of a mile below Normans Ferry, in loose blocksexcavated from channel; C. W. Cooke and J. E. Brantly, collectors.

7129. East bank of Flint River 1 mile below Windell's Landing, about 6 miles above Red Bluff; C. W. Cooke, collector.

The species is also present in Alabama at station 6747 , in the Ocala limestone at Steamboat Point, on the west side of Sepulga River at sharp bend near middle of see. 20, T. 3 N., R. 13 E., Escambia County; C. W. Cooke. collector.

In its gross appearance $L$. georgiana is suggestive of $L$. gigas Cushman, from Antigua, but the papillate character is much more clearly shown in L. georgiana and is correlated in the rertical section with the numerous pillars.

The largest specimens of $L$. georgiana seem to show definite seuescent characters in the loss of the papillate character of the surface, which becomes much smoother in the adult, and in the relatively less prominent umbo in the larger specimens. The scnescent feature is especially shown in the pillars, which in the younger specimens are conical, the outer end being the widest, whereas in the largest specimens they become smaller in the outer portion and as a result in section are somewhat fusiform.

Some of the exterual molds of the specimens, especially those obtained 3 miles southwest of Boykin station, Miller County, Ga., by C. T. Cooke, show eren more clearly than the specimens themselves the relative abundance and distribution of the external papillae formed by the distal ends of the pillars. 
This is by far the largest species of the Coastal Plain and is surpassed in size only by $L$. clephantina Munier-Chalmas, of Europe, and $L$. undulata Cushman, of Antigua.

\section{Lepidocyclina gigas Cushman. \\ Plate XIX, figures 1-4.}

Lepidocyctina gigas Cushman, Carnegie Inst. Washington Pub. 291, p. 64, pl. 1, figs. 3-5; pl, 5, fig. 4, 1919.

Test large, flattened, somewhat lenticular, circular in outline; central portion slightly umbonate; thence gradually thinning toward the periphery, which is bluntly angular; surface generally flat and smooth, occasionally slightly undulating.

The vertical section shows the equatorial chambers increasing somewhat in height from the central area toward the periphery, the peripheral end of each chamber slightly convex toward the exterior; lateral chambers broad and low, in vertical columns, usually from 7 to 10 in each column in the central portion of the test outside the umbo, thence gradually decreasing in number toward the periphery. Pillars are developed at irregular intervals but are few in number and of very small diameter.

Horizontal sections (Pl. XIX, fig. 4) show the hexagonal equatorial chambers, the annular rows of which are very uneven in size, and the subequal embryonic chambers.

Diameter of largest specimens 80 millimeters or more.

The type locality for this species is U. S. G. S. station 6862, Antigua, Leeward Islands, lower bed at Hodges Bluff; T. W. Vaughan, collector. Specimens from this locality are numerous and very fine. Material that is poorer but apparently specifically the same occurs at stations 6854, Rifle Butts, and 6857 , on the southwest side of Wetherell Mill, both in Antigua.

This species is very near to L. elephantina Munier-Chalmas, but the two early chambers do not seem to be at all alike, those of $L$. elephantina being very dissimilar in size and shape, whereas those of L. gigas so far as made out seem to be much more nearly equal, as is usual in American species of Lepidocyclina. Plate XIX, figure 4, shows the two early chambers of this species.

This is a very fine and large species and scems to be abundant at the type station.
Lepidocyclina gigas Cushman var. mexicana Cushman, n. var.

Plate XIX, figure 5; Plate XX, figures 1, 2; Plate XXI, figures 1-3.

Test differing from the typical L. gigas in the somewhat smaller size and the comparatively greater thickness at the umbo; the surface is apparently more reticulate, but this may be due to the different conditions of preservation in the two areas.

Diameter of the test as much as 50 millimeters or more; thickness in the umbonal region, 7 millimeters.

The vertical section (Pl. XIX, fig. 5) is very similar to that of $L$. gigas, but has a rather less number of lateral chambers, and the whole test except the umbonal region is somewhat thinner.

Typo specimen and others from Mexico collected by E. T. Dumble. The type, from the Meson formation, Meson, Vera Cruz, Mexico, is referred to by Dumble ${ }^{1}$ under the name "Orbitoides papyracea." Large specimens that seem very similar occur in the material collected by Dumble from the San Rafael formation at Cerro Cortado, Topila Hills, 15 miles southwest of Tampico. Some of the Topila Hills material contains other species, but they are not sufficiently well preserved for positive determination at present.

\section{Lepidocyclina fragilis Cushman, n. sp. Plate XXII, figures 1, 2.}

Test of medium size, 10 to 12 millimeters in diameter, very thin, flattened or very slightly sellaeform; central portion very slightly thickened but usually forming no definite umbo distinguishable from the remainder of the test; surface very smooth except where eroded and at the periphery, where the walls of the equatorial chambers form a slight reticulation of the surface; whole test thin and fragile; thickness usually about 1 millimeter or less.

The horizontal section shows the equatorial chambers to be hexagonal and with fairly thick walls. Embryonic chambers not seen.

The vertical section shows the equatorial band of chambers unusually low throughout, increasing very little from center to periphery; the chambers toward the center thin-walled

I Dumble, E. T., California Acad. Sci. Proc,, 4th ser., vol. 8, p.
147,1918 . 
and broader than high; those toward the periphery are thick-walled, slightly higher than wide, and the vertical walls slightly convex and thickened; lateral chambers very low and broad, in central region with not nore than six chambers in a vertical column, gencrally lessening in number toward the periphery, where there may be but one or even none. No pillars apparent.

Type specimens from U. S. G. S station 7194, Ocala limestone, at mouth of cavern about 200 yards southwest of wagon bridge over Chipola River, east of Mariamna, Fla.; bed 4 of section; C. W. Cooke and W. C. Mansfield, collectors. Specimens also occur at the following stations:

3760. Tivola tongue of Ocala limestone on Georgia Southern \& Florida Railroad half a mile south of Tivola, Ga.; S. W. Mccallie, collector.

6747. Ocala limestone at Steamboat Point ou west side of Sepulga River at sharp bend near middle of sec. 20 , T. 3 N., R. 13 F., Escambia County, Nla.; C. W. Cooke. collector.

7337. Left bank of Suwannee River above bridge of Florida Railway, Suwaunee County, Fla., northeast of Mayo; C. W. Cooke, collertor.

7348. Left bank of Suwannee River about 1 mile above Troy Springs, Fla.; C. W. Cooke, collector.

This is a very thin species and consequently fragile. The outer equatorial chambers, which are unprotected by the lateral chambers, have thickoned walls that give greater strength to this thin peripheral portion.

The species secms to be characteristic of Ocala limestone.

Lepidocyclina chaperi Lemoine and R. Douvillê.

Plate XXII, figures $3,4$.

Lepidacyclina chaperi Lemoine and $\mathrm{r}$. Douvillé, Soc. géol. France, Paléontologie, Mlém. 32, p. 14, pl. 2, fig. 5, 1904. Cushman, U. S. Nat. Mlus. Bull. 103, p. 92, pl. 35, figs. 1-3; pl. 36, 1918.

Test of medium size, diameter from 8 to 20 millimeters, circular in outline, somewhat saddle-shaped; central portion slightly thickened, thence gradually and evenly thinning toward the periphery; surface where well preserved slightly papillate, usually roughened by erosion, toward the periphery of ten somewhat reticulately depressed abore the equatorial chambers.

Vertical section usually curved; lateral chambers numerous, breadth much greater than height, columns separated by distinct pillars, comparatively few except in the central region, where there are a few larger than the others; embryonic chambers of the double type, the two chambers nearly equal in size and separated by a straight common wall.

The horizontal section shows similar conditions of the embryonic chambers and distinctly hexagonal equatorial chambers.

Lemoine and R. Dourillé described this species from Panama (Haut-Chagres, San Juan). The specimens figured came from U. S. G. S. station 6025, from marl at the south end of Bohio Ridge switch, on the relocated line of the Panama Railroad, collected by T. W. Vaughan and D. F. MacDonald, and from station 6019-f, on the west side of the Gaillard Cut near Las Cascadas. These specimens seem to represent the microspheric form of this species.

A specimen from station 6526, Chiriqui, Canal Zone, shows a section which from its general proportions seems to suggest strongly L. chaperi.

H. Douvillé ${ }^{1}$ records this species from Salt Mountain, Ala., but the material from the higher levels at this locality seems to be referable to L. supera (Conrad).

\section{Lepidocyclina vaughani Cushman.}

Plate XXII, figure 5.

Lepidocyclina vaughani Cushman, U. S. Nat. Mus. Bull. 103, p. 93, pl. 37, figs. 1-5; pl. 36, 1918.

Test of medium size, 10 millimeters or more in diameter, flat; surface somewhat umbonate in the central portion, gradually sloping to the peripheral portion, the outer half of which is nearly flat. Wall smooth except for fine papillae. The peripheral portion of the test when well preserved is typically much thickened, the edge thick and squarely truncated.

The horizontal section shows the peculiarity of the chambers, many of which, especially those of the outer peripheral portion, are rhomboid; those of the inner portion are more typical and hexagonal. These are shown especially well on the sections of the larger specimens, those of the smaller specimens showing only the regular hexagonal character of the earlier chambers.

No very good vertical sections were obtained in the thin sections, but several accidental sections show the characters well. The embry-

1 Compt. Rend., 1918, pp. 264, 265. 
onic chambers are rather large, of the usual American type, of two nearly equal chambers, lateral chambers in vertical columns with a very few rather well developed pillars.

Type specimen from station 6021, from the Emperador limestone in cuttings of the Panama Railroad near Caimito Junction, Panama, U. S. N. M. catalogue No. 324739, collected by T. W. Vaughan and D. F. MacDonald. Specimens were abundant in this light-gray to cream-colored sandy limestone. Specimens were also abundant in the collection from station 6673 , at the same locality, obtained later by MacDonald. Specimens that are apparently the same species are abundant in a fossiliferous limy sandstone collected by MacDonald at station 6255 , half a mile south of Miraflores station on the wagon road to Panama.

One of the most characteristic features of this species is the much thickened peripheral border, the increase toward the extreme edge being very rapid, leaving the periphery itself sharply truncate. This gives the appearance in hand specimens of a sliarply defined outline and in sections of the limestone is still more striking when vertical sections are seen.

Specimens from Georgia (U. S. G. S. station 7095, east bank of Flint River at old factory 2 miles above Bainbridge, occurring in chert and embedded in clays referred to the Chattahoochee formation; W. C. Mansfield, collector) have very much the characters of $L$. vaughani, especially in the chambers of the horizontal section. None of the specimens show the periphery well, so that its characteristic form is not available for comparison.

Lepidocyclina chattahoocheënsis Cushman, n. sp.

Plate XXIII, figures 1-4; Plate XXIV, figures 1, 2.

Test of medium size, flattened or somewhat undulate; largest specimens measuring 25 millimeters in diameter, most specimens less, 16 to 22 millimeters; central region much thickened, prominently umbonate, making up about one-third of the test, nearly 5 millimeters through in the center of the thickened region in large specimens; the thin flattened peripheral border usually smooth or very finely papillate; the umbonate central region pitted with numerous small depressions.

$131049^{\circ}-20 \longrightarrow 6$
The horizontal section shows the chamber's of the equatorial band either hexagonal or with the peripheral angle an even convex curve; walls rather thin; annuli somewhat irregular in thickness.

In vertical section (Pl. XXIII, fig. 4) the equatorial chambers increase in height toward the periphery, where they are at least three times as high as their diameter; lateral chambers compressed, broad and low, somewhat convex in the central region, where there are as many as 40 chambers in the central columns, diminishing in number toward the periphery, where in the flattened flangelike portion there are from 3 to 5 chambers superimposed, not together equaling the height of the equatorial chambers at the periphery. Pillars in the umbonal region strongly developed, wedgeshaped in section, the distal ends broadest and projecting beyond the lateral columns of chambers, giving the characteristic pitting of the surface.

Type specimen a vertical section from U. S. G. S. collection 3392, from the Chattahoochee formation at Glenns Well, 5 miles southeast of Bainbridge, Ga., collected by T. W. Vaughan. Specimens apparently identical with this species were obtained in material from the following localities:

3388. Upper fossiliferous horizon, Red Bluff on Flint River, 7 miles above Bainbridge, Ga.; T. W. Vaughan, collector.

3397. Old factory about $1 \frac{1}{2}$ miles above Bainbridge, Ga.; T. W. Vaughan, collector.

3647. Five miles south of Jackson, Ala.; T. W. Vaughan, collector.

7074. Coralliferous flint, Hales Landing, west bank of Flint River, 7 miles southwest of Bainbridge, Ga.; T. W. Vaughan, C. W. Cooke, and W. C. Mansfield, collectors.

? 7075. East bank of Flint River just above Lamberts Island, about $10 \frac{1}{2}$ miles below Bainbridge, Ga.; C. W. Cooke and W. C. Mansfield, collectors.

7133. Silicified fragments, lower end of Fort Scott bluff, west bank of Flint River, about 12 miles above River Junction, Decatur County, Ga.; C. W. Cooke, collector.

In some of its characters this species resembles L. favosa Cushman, from Antigua, but it is less undulate and its umbonal region is not so prominent nor so distinctly reticulate as in L. favosa. L. favosa does not attain so large a size as L. chattahoocheënsis. The number of lateral chambers in the central columns in the species here described is unusually large. 
Lepidocyclina favosa Cushman.

Plate XY, figure 5 (B).

Lepidocyclina favosa Cushman, Carnegie Inst. Washington Pub. 291, p. 66, pl. 3, figs. 1, 2b; pl. 15, fig. t, 1919.

Test of medium size, compressed, strongly undulate or saddle-shaped; the central portion umbonate, much curved, thick; the remainder of the test thin and flangelike; central umbonate mass with an ornamentation of polygonal areas caused by rounded raised ribs; remainder of the test fairly smooth, but in most specimens irregularly croded.

The rertical section shows numerous distinct pillars in the umbonate region, broad at the exterior and narrowing to a point near the equatorial chambers; flattened peripheral portion with few indistinct pillars.

Diameter, 15 to 18 millimeters for typical specimens.

The type locality for this species is U. S. G. S. station 6881, Antigua, Leeward Islands, bluffs on north side of Tilloughby Bay.

This is a very strikingly ornamented species and hardly likely to be mistaken for any other, especially with its very strong saddle shape in addition. It was not seen in any other material from the Antigua formation but is very abundant at this station, as the photograph (Pl. XV, fig. 5) will show.

Lepidocyclina pseudocarinata Cushman, n. sp.

Plate XXIY, figures 3,4 .

Test of medium size, 18 millimeters in diameter in the largest specimen, generally without sellaeform curves; central portion thickened but only slightly convex; the thickened portion ocrupying about two-thirds of the surface of the test; peripheral portion flattened and thin, the change from the thickened center abruptly marked; surface smooth except for scrobiculations due to the erosion of the surface.

The horizontal section shows the equatorial band of chambers hexagonal.

'The vertical section shows the equatorial band of chambers increasing gradually in size toward the periphery, where the height is three to four times the width; walls thick, very slightly convex; lateral chambers numerous in the central portion, rapidly diminishing in numbers at the point where the abrupt change occurs from the central thickening to the thin periphery; outer surface curved; inner surface flattened, not greatly compressed; lateral chambers over the peripheral carina usually wanting; the entire borler almost completely formed by the equatorial band.

Type specimen from U. S. G. S. collection 6810, Ocala limestone, Cunmer Lumber Co.'s phosphate plant No. 10, 1 mile northwest of Newberry, Fla.; C. W. Cooke, collector. It was also found at the following stations in Florida:

5031. Ocala, Marion County; G. C. Matson, collector. 6790. 300 feet south of the Alachua Manufacturing Co.'s plant at south edge of Alachua, Fla.; II. Gunter and C. IT. Cooke, collectors.

6812. Cummer Lumber Co.'s phosphate plant No. 6, $1 \frac{x}{4}$ miles south of Newberry; C. IV. Cooke, collector. 6814. Quarry of Franklin Phosphate Co., $1 \frac{1}{2}$ miles northwest of Newberry, Alachua County; C. W. Cooke, collector.

7194. Ocala limestone, mouth of cavern about 200 yards southwest of wagon bridge over Chipola River east of Marianna; bed $t$ of section; C. WT. Cooke and WV. C. Mansfield, collectors.

7341. Left bank of Suwannee River at Branford, Suwannee County; C. W. Cooke, collector.

7349. Left bank of Suwannee River about half a mile below Fort McComb; C. W. Cooke, collector.

7367. Willow Sink, $1 \frac{1}{3}$ to 2 miles west of Chiefland, Levy County; C. W. Cooke, collector.

In Georgra specimens from two localities appear to be identical with this:

6160. Flint River north of Plue Spring, 4 miles below Bainbridge; L. W. Stephenson, collector.

7097. East bank of Flint River above old factory at bend three-quarters of a mile northeast of Atlantic Coast Line Railroad station at Bainbridge; C. W. Cooke and IV. C. Mansfield, collectors.

This species may be distinguished from most of the other species of the Ocala limestone by its carinate appearance and from the only other species of the same formation that has this same character, L. cookei, by its smooth or irregularly scrobiculate surface when eroded, as contrasted with the very papillate surface of L. cookei. It will probably be found to have a wider geographic range than is here indicated, but it is not a common speeies in comparison with $L$. ocalana or $L$. floridana, with which it is associated.

Lepidocyclina cookei Cushman, n. sp.

Plate XXIV, figures $5,6$.

Test rather small, 10 millimeters in diameter in the largest speeimen, thick, very convex in the central portion, at the periphery extending out into a thin border, the transition rather sharply marked; surface very strongly papil- 
late over the whole central portion; the thin periphery smooth except for erosion and the reticulate markings formed by the walls of the equatorial chambers.

Sections were not made, as the species seems to be very rare, but accidental breaks show that the equatorial chambers are hexagonal and of uniform size, the height increasing as usual toward the periphery but not excessively so; lateral chambers wanting over the thin periphery; numerous pillars are indicated by the closely set papillae of the surface of the thickened central portion.

Type specimen from U. S. G. S. station 6812, Ocala limestone, Cummer Lumber Co.'s phosphate plant No. 6, $1 \frac{1}{4}$ miles south of Newberry, Fla.; C. W. Cooke, collector. The only other specimen known is from station 4965, half a mile southwest of Fort White, Fla.; G. C. Matson, collector.

From the available material the species seems to be rare in the Ocala limestone, but probably it has a wider range than is indicated by these records.

Lepidocyclina attenuata Cushman, n. sp.

Plate XXIV, figures 7,8 .

'Test of medium size, in all specimens examined close to 12 millimeters in diameter, plane or slightly sellaeform; central portion strongly umbonate, the thickened portion occupying about one-fourth the diameter; remainder of the test thin; central portion finely papillate; peripheral portion smooth or scrobiculate where eroded. Chambers of the equatorial zone hexagonal.

The vertical section shows the equatorial chambers low in the central portion and increasing rapidly in height toward the periphery until at the edge they are three to four times as high as broad, outer wall convex; lateral chambers very numerous in the thickened umbonal region, where there are 20 to 25 chambers in a vertical column, rapidly decreasing in numbers as the edge of the umbo is reached, thence gradually reduced toward the periphery, chambers low and broad, several times as wide as high; walls comparatively thin; pillars numerous, slender, increasing gradually in diameter toward the surface.

Thickness of umbonal region 3 millimeters in a test 12 to 13 millimeters in diameter.
Type specimen from U. S. G. S. station 6814, quarry of Franklin Phosphate Co., $1 \frac{1}{2}$ miles northwest of Newberry, Alachua County, Fla.; C. W. Cooke, collector.

Other Florida specimens were obtained at the following stations:

4974. Six miles southwest of Chipley, on west side of St. Andrews Bay road; G. C. Matson, collector. 5031. Ocala, Marion County; G. C. Matson, collector. 6824. East bank of Suwannee River at Seaboard Air Line Railway bridge opposite Ellaville, Fla., bed 1 of section; C. W. Cooke, collector.

7194. Mouth of cavern about 200 yards southwest of wagon bridge over Chipola River east of Marianna; bed 4 of section; C. W. Cooke and IV. C. Mansfield, collectors. 7199. Contact of beds 4 and 5 of same section. W. C. Mansfield, collector.

7348. Left bank of Suwannee River about 1 mile ahove Troy Springs; C. W. Cooke, collector.

U. S. N. M. No. 112507, Richards quarry, Ocala.

It is apparently present in Georgia at station 3380, base of bluff at Little Horseshoe Bend, just below mouth of Blue or Russell Spring, Flint River, 4 miles below Bainbridge, Decatur County; T. W. Vaughan, collector.

It may be distinguished from the other species of the Ocala limestone by the prominent umbonate portion, occupying but a quarter of the diameter of the test, and the large proportion of flattened periphery.

\section{Lepidocyclina floridana Cushman, n. sp.}

Plate XXV, figures 1, 2.

Test small, thin, very sellaeform; usual size of specimens from 4 to 8 millimeters in diameter; sellaeform condition very regular, the bending of the test being somewhat greater in measurement than half the diameter of the test. In a specimen measuring 7 millimeters in diameter the entire deviation from the plane through the center is as much as 4 millimeters; surface appearing smooth to the unaided eye but with slight magnification shown to be finely papillate from the projection of the ends of the vertical pillars, especially in the central part of the test but more or less so over the whole test.

The horizontal section shows the chambers of the equatorial band with the characteristic hexagonal shape, those near the periphery with the outer border convexly curved, annuli irregular.

The vertical section shows the chambers of the equatorial band in the central part square in section, the height about equaling the width 
but gradually increasing toward the peripheral portion of the test, where the chambers beeome about three times as high as their width, and the walls, instead of being straight, are convexly eurved toward the periphery of the test; lateral chambers much compressed, broad and low, eight or nine in a rertical column in the central region, diminishing rery ovenly in number toward the periphery, where there is but a single chamber on each side of the test. Pillars numerous, rather evenly distributed, rery slightly increasing in diameter toward the surface, only slightly laminated, coming slightly above the surface at the distal ends, causing the papillate surface.

Type specimen from U. S. G. S. station 6805 , Ocala limestone, at plant of Oakhurst Lime Co. (plant No. 2, Florida Lime Co.), south of Atlantic Coast Line Railroad, 2 miles southeast of Ocala, Fla.; C. W. Cooke, collector. Material containing this species has been collected at the following stations in Florida:

329. Deep wells at Padlock, Suwannee County; I. C. Johnson, collector.

362. Fort White, Suwannee County; I. C. Johnson, collector.

3629. Alachua; T. W. Vaughan, collector.

4965. Half a mile south west of Fort White; G. C. Matson, collector.

4974. Six miles southwest of Chipley, on west side of St.

Andrews Bay road; G. C. Matson, collector.

6717. Fort White.

6789. Torth side of Alachua-IIigh Springs public road, 1 mile west of North Alachua station, Atlantic Coast Iine Railroad, Alachua County; T. W. Vaughan, collector.

6790. Three hundred feet south of Alachua Manufarturing Co.'s plant at south edge of Alachua; H. Gunter and C. W. Cooke, collectors.

6804. Quarry No. 1, Florida Lime Co., on southwest erlge of Ocala; C. W. Cooke, collector.

6807. Plant No. 3, Florida Lime Co., $6 \frac{1}{2}$ miles north of Ocala, at Zuber, Marion County; C. W. Cooke, collector.

6808. Quarry one-eighth of a mile southeast of Martin station, Atlantic Coast Line Railroad, 9 miles north of Ocala; H. Gunter and C. W. Cooke, collectors.

6810. Cummer phosphate plant No. 10,1 mile northwest of Newberry; C. W. Cooke, collector.

6\$12. Cummer Lumber Co.'s phosphate plant No. 6, 11 miles south of Newberry; C. W. Cooke, collector.

6514. Quarry of Franklin Phosphate Co., $1 \frac{1}{2}$ miles northeast of Newberry; C. W. Cooke, collector.

6858. Near Alachua.

7126. East bank of Flint River at Iry Bread Shoals, Mitchell County, $8 \frac{1}{2}$ or 9 miles below Newton, from lumps blasted from the channel; C. W. Cooke, collector.

7194. Nouth of cavern about 200 yards southwest of Wagon bridge over Chipola River, east of Marianna; bed 4 of section; C. W. Cooke and W. C. Mansfield, collectors,

7338. Suwannee River at Dowling Springs, Suwannee County; C. W. Cooke, collector.
7348. I ceft bank of Suwannee River about 1 mileabove Troy Springs; C. W. Cooke, collertor.

7319. I,eft bank of Suwannee River alout half a mile below Fort MrComb; C. W. Cooke, collector.

7354. Manatee Spring, Levy County, C. W. Cooke, collector.

7367. Willow Sink, $1 \frac{1}{3}$ to 2 miles west of ('hiefland, Levy County; C. IV. Cooke, collector.

U.S. N. M. No. 112507. Richards quarry, ()ala; Joseph Willcox, collector.

In Alabama the speeies has been found at station 6747 , Steamboat Point, on west side of Sepulga River, at sharp bend near middle of sec. 20, T. 3 N., R. 13 E., Escambia County; C. W. Cooke, collector.

\section{Lepidocyclina perundosa Cushman.}

Plate XXVI, figure 1.

Lepidocyctina perundosu Cushman, Carnegie Inst. Washington Pub. 291, p. 63, pl. 11, fig. 8, 1919.

Test very much curved in two directions, so that the two planes of each set are nearly parallel to one another and nearly at right angles to those of the other set, strongly "saddle-shaped"; surface smooth when well preserved but usually somewhat cancellate, owing to erosion.

A vertical section is difficult to obtain on account of the very much doubly eurred shape of the test but shows no pillars, the lateral chambers about three times as long as high, central chamber large, equatorial chambers increasing gradually in size toward the periphery, height and breadth of equatorial chambers about equal.

Owing to the shape of the test the horizontal section is only fragmentary, but it shows chambers roughly triangular with the outer surface convexly curved.

Diameter, 8 to 12 millimeters.

Type specimen, seetion (U. S. N. M. No. 328194) from station 3478, Nueritas, Cuba; A. C. Spencer, collector.

This is a rery sellaeform species about onehalf the size of $L$. undosa Cushman, from $\mathrm{An}$ tigua.

\section{Lepidocyclina undosa Cushman.} Plate $\mathrm{XIT}$, figure 3

Lepidocyclina undosa Cushman, Carnegie Inst. Waslington Pub. 291, p. 65, pl. 2, fig. 1a, 1919.

'Test of medium size, much compressed, strongly undulate or saddle-shaped, not at all umbonate, thin thronghout; surface slightly granulate, otherwise smooth, where worn usually" netted by the walls of the chambers. 
Vertical sections show apparently an entire absence of pillars throughout; equatorial chambers nearly square in section, walls straight; lateral chambers very numerous, low and broad, very thin-walled, 12 to 15 in a vertical column in the thicker portions of the test.

Horizontal sections show typical hexagonal equatorial chambers.

Diameter as much as 25 millimeters or more.

Type material (U. S. N. M. No. 328198) from Antigua, Leeward Islands, U. S. G. S. station 6869, Long Island, T. W. Vaughan, collector. The species is very abundant in this material, making up a large proportion of the rock mass. Specimens are associated with Heterostegina.

This may be distinguished from other species of Lepidocyclina by its saddle-shaped test, the flat, nonumbonate center, the finely netted surface in worn specimens, and the absence of pillars in the vertical section, with the thin-walled chambers.

Lepidocyclina schlumbergeri Lemoine and R. Douvillê.

Lepidocyclina schlumbergeri Lemoine and R. Douvillé, Soc. géol. France, Paléontologie, vol. 12, Mém. 32, p. 14, pl. 1, fig. 10; pl. 2, fig. 6, 1904.

Cushman, Carnegie Inst. Washington Pub. 291, p. 57,1919

Test large, compressed, lenticular, thickest in the central region, from which it gradually thins out toward the periphery, somewhat flexuous and slightly saddle-shaped; surface fairly smooth or somewhat finely granular, the granules representing the ends of the small pillars; surface often uneven, owing to the raised peripheral walls of the lateral chambers.

The vertical section shows the general shape, thin, gently curving from the center to the periphery, slightly curved; the pillars numerous and comparatively small, a very fow larger pillars in the central region; vertical columns of lateral chambers with numerous low, flattened chambers making up each column.

The horizontal section shows hexagonal chambers, but more numerous equatorial ones with the outer wall convexly curved, walls rather thick.

Diameter, 25 to 35 millimeters.

Lemoine and $R$. Douvillé regard this as a mutation of $L$. dilatata. They record this species especially from Spain at four localities. In Cuba it has been found at stations 7512, Ocujal; 7518, south side of Los Melones Moun- tain near west end; 7522, Mogote Peak; 7543, limestone outcrop, east side of Yateras River; 7664, north slope of La Piedra, northeast of Jamaica, northeast of Guantanamo, collected by N. H. Darton.

Lepidocyclina pseudomarginata Cushman, n. sp. Plate XXVI, figures 2-4.

Test of medium size, 12 to 15 millimeters in diameter, slightly sellaeform; central portion thickened and occupying nearly half the diameter of the entire test, entire thickness about one-fourth the whole diameter of the test; peripheral portion thin; central thickened portion strongly papillate from the projecting ends of the pillars, which gradually decrease in number as the thinner peripheral portion is approached; line of demarcation not abrupt; papillae of the central portion very numerous and rather evenly distributed.

Equatorial chambers hexagonal, showing at the surface only on the extreme periphery; the remainder of the thin portion toward the center covered with one or more layers of lateral chambers.

Type specimen from U. S. G. S. station 3683, Archer, Fla.; W. H. Dall, collector. A very small specimen (U. S. N.M. No. 136425) may be the young of this species. It is from Johnson's sink, Levy County, Fla.; L. C. Johnson, collector. Other specimens were obtained at the following stations:

7194. Ocala limestone, Marianna, Fla.; bed 4 of section, at mouth of cavern; C. W. Cooke and W. C. Mansfield, collectors.

7338. Suwannee River at Dowling Springs, Suwannee County, Fla.; C. W. Cooke, collector.

This species resembles $L$. marginata, but the central region is much more finely papillate, the number of papillae being double that in L. marginata. It seems to be a rare species in the Ocala limestone.

Lepidocyclina supera (Conrad) H. Douvillé.

Plate XXVI, figures 5-7.

Orbitolites supera Conrad, Acad. Nat. Sci. Philadelphia, Proc., No. 2, p. 74, 1865.

Orbitoides supera Conrad, Am. Jour. Sci., $2 d$ ser., vol. $\iota_{i} 3$, p. $31,1867^{\circ}$

Lepidocyclina supera (Conrad) H. Douvillé, Compt. P.end., 1918, pp. 263, 264, figs. 6-8, 11.

Test flattened or slightly sellaeform, typically circular in outline but occasionally irregular, 
with lobes at one side or elongated oval; thickest in the central region but not distinctly umbonate, gradually decreasing in thickness to the periphery; surface apparently smooth but with slight enlargement becoming papillate, the papillae, which are the ends of the pillars rounded and projecting above the general surface slightly, or where the test is eroded becoming more prominent. Diameter as much as 18 millimeters in adult specimens; thickness about 2 millimeters.

The horizontal section shows the chambers of the equatorial band to be irregularly hexagonal, the chambers with thick walls, the annuli irregular, occasionally much crowded, the chambers then compressed and elongate oval; embryonic chambers not seen.

The vertical section shows the equatorial band to be unusually thin, inereasing somewhat in thickness toward the periphery, where the height of the chambers is 2 to $2 \frac{1}{2}$ times the radial width; lateral chambers numerous, 10 to 12 in a column in the thickest portion of the test, thence decreasing gradually in number toward the periphery; chambers very much compressed, 6 to 8 times as wide as high, elliptical, the walls thick, usually much thicker than the chamber itself; pillars very numerous, increasing rapidty in diameter toward the surface, most numerous in the thicker central portion but in lesser numbers scattered over the surface well toward the periphery.

Conrad describes this species from the upper bed at Vicksburg (hence probably the specific name supera) in the following words:

Smaller than the preceding $[L$. mantelli] and comparatively thicker withont the raised central point. Diameter thirteen-twentjeths of an inch. This species is readily distinguished by the convex center and is limited to the Oligocene strata.

L. supera seems to be a characteristic species of the upper part of the lower Oligocene, now known as the Byram calcareous marl. It has been found at the following stations in Mississippi:

259. Vicksburg.

2664. Yicksburg; C. W. Johnson, collector.

3722. Vicksburg, bluff just above the second sawmill on the river, horizon No. 2 from the top; T. W. Vaughan, collector.

3729. Top of bluff opposite second sawmill, Vicksburg; T. W. Vaughan, collector.

5623. West bank of Pearl River, Byram, Hinds County; G. C. Matson, collector.
6449. Upper fossiliferous zone, ('onfederate Avenue, 600 to 700 feet north of the bridge over Glass Bayou, Vicksburg; ('. W. C'ooke, collector.

6454. Pearl River just alove brilge at Byram; $($. W. Corke, rollector.

6458. Rock quarry 4 miles east of Brandon, south of Rankiu, on Alabama \& Vicksburg Railway, Rankin County; T. W. Vaughan, collector.

6648. Chickasawhay River at wagon bridge a quarter of a mile west of Wood ward and 2 miles northwest of Waynesboro County; C. W. Cooke, collector.

The following localities in Nlabama seem to have this species:

3646. Salt Mountain, Clarke County, near the top of the series; 'T. W. Vaughan, collector.

3648. Salt Mountain, near top of the hill :T. W. Vaughan, collector.

H. Douville ${ }^{1}$ has recorded L. supera from Vicksburg and Byram, Miss., from a locality southeast of Claiborne on Conecuh River, Ala., and from Bainbridge, Ga. I have had much material from Bainbridge but have had no material that seemed to fit this species. The embryonic chambers of a specimen from Bainbridge, figured by Douvillé, are very thick walled and seem much more like some of the Ocala species. Douvillé gives $L$. superu as occurring in the "upper Jackson-Zeuglodon bed."

The species there that is superficially like $L$. supera in some respects is that here described as L. mortoni.

So far as the material I have had shows, $L$. supere is confined to the Byram marl and formations of equivalent age.

Lepidocyclina mortoni Cushman, n. sp.

Plate XXYII, figures 1-4; I'late XXVIII, figures 1, 2.

Test flattened, usually somewhat sellaeform, thin; central portion thickest but not umbonate; surface very finely papillate throughout, the papillae most numerous in the central portion. Diameter as much as 20 millimeters; thickness slightly more than 1 millimeter.

The horizontal section shows the chambers of the equatorial band hexagonal in general, but the peripheral portion more commonly a convex curre instead of a sharp angle; embryonic chambers subequal in the megalospheric form, thick-walled.

The rertical section shows the chambers of the equatorial band very low, in the center sliglstly wider than the height but toward the periphery slightly larger and slightly higher

3Compt. Rend., 1918, pp. 264, 265. 
than the width, walls thick and at right angles, not showing the convexity of the outer wall so common in most species; lateral chambers seven or eight in a column in the thickened central portion, broad and low, the outer wall usually convex, making the chamber cavity roughly lunate, the walls of the inner chambers nearest the equatorial chambers often much thickened and the chamber cavity reduced to mere slits, the walls often double the thickness of the entire equatorial band at that point, the walls of the outer layers much thinner and the chamber cavities somewhat wider but not proportionately so; pillars very numerous, more or less irregular, often anastomosing, especially toward the surface.

Type specimen from the Jackson formation at U. S. G. S. station 2638, bluff at Montgomery, Grant Parish, La.; T. W. Vaughan, collector, 1894. The species is represented by abundant specimens from the marl at this place. The same species was collected at station 4270 , at the same locality, by T. W. Vaughan, in 1900. Very similar specimens occur at the following stations:

7161. Ocala limestone, roadside 500 feet east of Jones Field Branch, sec. 35, T. 8 N., R. 3 E., 5 miles southeast of Whatley, Ala.; C. W. Cooke, collector.

7377. Jackson formation, bluff on south side of Suck Creek, Clarke County, Miss., about three-quarters of a mile from mouth (in the NE. $\frac{1}{4}$ sec. 3 , T. 10 N., R. 7 E., in "Zeuglodon bed"; E. N. Lowe and C. W. Cooke, collectors.

Both microspheric and megalospheric forms of the test occur. The pillars are peculiar in their anastomosing condition and are shown in the horizontal section (Pl. XXVII, fig. 3).

Lepidocyclina ocalana Cushman, n. sp.

Plate XXVIII, figures 3, 4; Plate XXIX, figures 1-3.

Test of medium size, flattened, usually slightly sellaeform; usual diameter of specimens from 16 to 18 millimeters, with the range of adult specimens from 15 to 21 millimeters; the two sides of the tests differing; one side typically prominently umbonate in the central portion, thence gradually sloping to the periphery; the opposite side thickened in the center but not umbonate, evenly curved from one side to the other; the umbonate side showing more clearly the sellaeform shape than the more evenly curved side; surface typically smooth or somewhat scrobiculate from unequal erosion of the outer layer of lateral chambers.
The horizontal section shows the chambers of the equatorial band usually with the outer portion of each chamber convexly curved, on the whole hexagonal, walls comparatively thick, thinner near the periphery; annuli irregular; embryonic chambers subequal, thickwalled.

In vertical section the chambers of the equatorial zone increase but very slightly in height toward the exterior; lateral chambers much compressed, broad and very low, from 15 to 20 in a vertical column in the umbonal region but rapidly diminishing in number toward the periphery. Pillars very numerous, more so in the central region but well distributed throughout the test except at the peripheral portion, in section wedge-shaped, distal end broadest, thence tapering gradually to the center, usually showing longitudinal laminations in section, outer end flat or very slightly convex, not coming above the adjacent lateral chambers and therefore not causing a papillate surface, as is so usual with a species in which the pillars are numerous; in some specimens the pillars seem to become obsolete before the surface is reached.

Type specimen from U. S. G. S. station 6804 , Ocala limestone, quarry No. 1, Florida Lime Co., Ocala, Fla.; C. W. Cooke, collector. Tests of this species have been found also at the following stations:

322. Quarry of chimney rock near railroad half a mile west of Gainesville, Fla.; L. C. Johnson, collector.

329. U. S. N. M. catalogue No. 136397, Fort White, Fla.; L. C. Johnson, collector.

355. Bennett's bone bed, Nixon, Levy County, Fla.; L. C. Johnson, collector.

362. Fort White railroad station, Suwannee County, Fla.; L. C. Johnson, collector.

365. U. S. N. M. catalogue No. 136425, Johnson's lime sink, Levy County, Fla.; L. C. Johnson, collector.

$378 \mathrm{~b}$. Near the "sink" 2 miles south of Gainesville, Fla.; L. C. Johnson, collector.

380. Vicinity of Gainesville and Arredonda, Alachua County, Fla.; L. C. Johnson, collector.

2284. Martin station, Marion County, Fla.; W. H. Dall, collector, 1891.

2325. Fort White, Columbia County, Fla.

3629. Alachua, Fla.; T. W. Vaughan, collector.

3682. Six miles southwest of Gainesville, Fla.; Weatherby, collector.

3683. Archer, Fla.; W. H. Dall, collector.

3685. Martin's station, Fla.; W. H. Dall, collector.

3688. Richard's quarry, Ocala, Fla.; Joseph Willcox, collector.

3781. Bank of Allapaha River, Statenville, Echolls County, Ga.; S. W. McCallie, collector. 
4965. Half a mile southwest of Fort White, Columbia County, Fla.; G. C. Matson, collector.

5030, 5031. Ocala, Marion County, Fla.; G. C. Matson, collector, 1908 .

6717. Fort White, Fla.

6747. Steamboat Point, on west side of Sepulga River at sharp bend near middle of sec. 20 , T. 3 N., R. 13 E., Escambia County, Ala.; C. W. Cooke, collector.

6785. Dutton's phosphate spur, on Atlantic Coast Line Railroad, one-half to one-fourth mile south of Herlong station, Fla.; T. W. Vaughan and C. W. Cooke, collectors.

6789. North side of Alachua-High Springs public road, 1 mile west of Alachua station, Atlantic Coast Line Railroad, Alachua County, Fla.; T. W. Vaughan, collector.

6790. Three hundred feet south of Alachua Manufacturing Co.'s plant, south edge of Alachua, Alachua County, Fla.; H. Gunter and C. W. Cooke, collectors.

6803. Hilltop on land of Evans Hale, 2 miles west of Arredonda and 1 mile north of Kanapaha station, Alachua County, Fla.; H. Gunter and C. IV. Cooke, collectors.

6805. Plant of Oakhurst Lime Co., (plant No. 2, Florida Lime Co.), south of Atlantic Coast Line Railroad 2 miles southeast of Ocala, Fla.; C. W. Cooke, collector.

6807. Plant No. 3, Florida Lime Co., $6 \frac{1}{2}$ miles north of Ocala, at Zuber post office, Marion County, Fla.; C. W. Cooke, collector.

6808. Quarry one-eighth of a mile southeast of Martin station, Atlantic Coast Iine Railroad, 9 miles north of Ocala, Fla.; H. Gunter and C. W. Cooke, collectors.

6810. Cummer phosphate plant No. 10, 1 mile northwest of Newberry, Fla.; C. W. Cooke, collector.

6812. Cummer Lumber Co.'s phosphate plant No. 6, $1 \frac{1}{2}$ miles south of Newberry, Alachua County, Fla.; C. W. Cooke, collector.

6514. Quarry of Franklin Phosphate Co., 1 $\frac{1}{2}$ miles northwest of Newberry, Alachua County, Fla.; C. W'. Cooke, collector.

6858. Near Alachua, Fla.

7082. Hales Landing, west bank of Flint River 7 miles southwest of Bainbridge, Ga.; T. W. Vaughan, C. W. Cooke, and W. C. Mansfield, collectors.

7097. East bank of Flint River above old factory at bend three-fourths of a mile northeast of Atlantic Coast Line Railroad station at Bainbridge, Ga.; C. W. Cooke and W. C. Mansfield, collectors.

7126. East bank of Flint River at Dry Bread Shoals, Nitchell County, Ga.; $8 \frac{1}{2}$ or 9 miles below Newton, from lumps blasted from the channel; C. W. Cooke, collector.

7194. Mouth of cavern about 200 yards southwest of wagon bridge over Chipola River, east of Marianna, Fla.; bed 4 of section; C. W. Cooke and W. C. Mansfield, collectors.

7195. Same locality as 7194, bed 5 of section; C. W. Cooke and W. C. Mansfield, collectors.

7242. West bank of Chipola River at wagon bridge east of Marianna, Fla.; bottom of bed 5 of section; W. C. Mansfield, collector.

7337. Left bank of Suwannee River above bridge of Florida Railway, northeast of Mayo, Suwannee County, Fla.; C. W. Cooke, collector.

7338. Suwannee River at Dowling Springs, Suwannee County, Fla.; C. IF. Cooke, collector.
7341. Left bank of Suwannee River, at Branford, Suwannee County, Fla.; C. W. Cooke, collertor.

7345. East bank of Suwannee River $2 \frac{1}{4}$ miles above Branford, Suwannee County, Fla.; C. W. Cooke, collector. 7349. Left bank of Suwannee River about half a mile below Fort McComb, Fla.; C. W. Cooke, collector.

7360. Rock quarry east of Atlantic Coast Line Railroad about $3 \frac{1}{2}$ miles south of Floral City and about $1 \frac{1}{2}$ miles north of Pineola, Fla.; C. W. Cooke, collector.

7365. Pineola, Citrus County, 5 miles south of Floral City, Fla.; C. W. Cooke, collector.

7367. Willow Sink, $1 \frac{1}{3}$ to 2 miles west of Chiefland, Levy County, Fla.; C. W. Cooke, collector.

7672. Ocala limestone, (hipola River at Louisville \& Nasliville Railroad, three-fourths mile east of Marianna, Fla.; C. W. Cooke, collector.

U. S. N. M. No. 112507. Richards quarry, Ocala, lia.; Joseph Willcox, collector.

U. S. N. M. No. 137924. Archer, Fla.; W. H. Dall, collector.

Specimens from U. S. G. S. station 7689 (Tivola tongue of Ocala limestone, Tivola, Ga.; C. W. Cooke, collector) are evidently this species with the variety subdecorata, described below.

Both the species and its variety seem to be bighly characteristic of the Ocala limestone in west-central Florida and are very abundant. The development and subsequent reduction of pillars seem to indicate senescent characters oven in the upper Eocene. The species seems to be to a great extent replaced in Georgia and elsewhere by the very much larger $L$. georgiana, unless it occurs there at different horizons.

Lepidocyclina ocalana Cushman var. subdecorata Cushman, $n$. var.

Plate XXVIII, figure 5.

Variety differing from the typical species in its usually thinner, more distinctly umbonate test, and surface with prominent papillae, eren near the periphery.

In most material in which typical $L$. ocalana occurs this variety also is present. In size and general characters the two are similar, but the variety is distinctly papillate throughout, a character which may be accompanied by the thinner and more umbonate test. As a rule this is not as common as the typical form, but in one or two lots of material it seems to be fairly common while the typical form is rare or absent.

It was noted in material from the following stations: 
365. Johnsons Sink, Levy County, Fla.; L. C. Johnson, collector.

3629. Ocala limestone, Alachua County, Fla.; T. W. Vaughan, collector.

4965. Half a mile southwest of Fort White, Columbia County, Fla.; G. C. Matson, collector.

4974. Six miles southwest of Chipley, Fla., on west side of St. Andrews Bay road; G. C. Matson, collector.

6789. North side of Alachua-High Springs public road 1 mile west of North Alachua station on Atlantic Coast Line Railroad, Alachua County, Fla.; T. W. Vaughan, collector.

6804. Quarry No. 1, Florida Lime Co., on southwest edge of Ocala, Fla.; C. W. Cooke, collector.

6807. Plant No. 3, Florida Lime Co., $6 \frac{1}{2}$ miles north of Ocala, at Zuber post office, Marion County, Fla.; C. IV. Cooke, collector.

6808 . Quarry one-eighth of a mile southeast of Martin station, Atlantic Coast Line Railroad, 9 miles north of Ocala, Fla.; H. Gunter and C. W. Cooke, collectors.

6810. Cummer Lumber Co.'s phosphate plant No. 10, 1 mile northwest of Newberry, Alachua County, Fla.; C. W. Cooke, collector.

6812. Cummer Lumber Co.'s phosphate plant No. 6, 1 miles south of Newberry, Alachua County, Fla.; C. WV. Cooke, collector.

7338. Suwannee River at Dowling Springs, Suwannee County, Fla.; C. W. Cooke, collector.

Specimens from station 7689 (Tivola, Ga.; C. W. Cooke, collector) seem to be this variety.

\section{Lepidocyclina subraulinii Cushman.}

Plate XXX, figures 1-6.

Lepidocyclina subraulinii Cushman, Carnegie Inst. Washington Pub. 291, p. 62, pl. 11, figs. 6,$7 ;$ pl. 12 figs. 5, 6, 1919.

Test circular, much thickened in the central portion, which occupies about one-third the diameter of the test; peripheral portion much flattened, thin; thick central portion irregularly papillate, peripheral portion smooth, showing almost no tendency to become saddle-shaped.

The vertical section shows the general thickness, central lenticular body, and thin periphery, central portion with very numerous pillars increasing in diameter toward the surface; lateral chambers crowded between the pillars, very numerous in the vertical columns and much wider than high; equatorial chambers increasing in diameter toward the periphery, the outer margin convex and with a series of fine pores.

The horizontal section shows the equatorial chambers, which are polygonal, the outer margin strongly convex; pillars subpolygonal with the lateral chambers making irregular polygonal meshes between, toward the periphery, making up the entire test as the pillars decrease in number.

Diameter as much as 24 millimeters; thickness in center 4.5 millimeters.

The type locality of this species is U. S. G. S. station 3478, Nuevitas, Cuba, collected by A. C. Spencer. Other specimens that apparently belong to this species occur at station 7666, Sierra Guaso, northeast of Guantanamo, Cuba, collected by N. H. Darton.

In diameter and general shape this species suggests $L$. raulinii Lemoine and R. Douvillé, but it has very definite pillars and a papillose surface at the center.

Certain specimens collected by E. T. Dumble from the Meson formation at San Jose de las Rusias, Mexico, seem very close to this species.

Lepidocyclina marginata (Michelotti) Lemoine and $\mathbf{R}$. Douvillé.

Plate XXXI, figures 1-2.

Nummulites marginata Michelotti, Soc. ital. sci. Mem., vol. 22 , p. 297, pl. 3, fig. 4, 1841.

Lepidocyclina marginata (Michelotti) Lemoine and $\mathrm{R}$. Douvillé, Soc. géol. France, Paléontologie, vol. 12, Mém. 32, p. 16, pl. 1, fig. 7; pl. 2, figs. 7, 9, 11, 20; pl. 3, figs. 3, 8, 9, 13, 1904.

Cushman, Carnegie Inst. Washington Pub. 291, p. 60 , pl. 12, figs. 1, 2, 1919.

'Test of small or medium size, lenticular, thickest in the central region, thence tapering gradually to the periphery, which in the adult forms a thin flange about the thicker central portion; central portion with numerous prominent pustules, rather evenly placed and of good size, representing the outer end of the pillars, flange smooth except for roughness caused by weathering.

The vertical section shows the general shape already noted, the numerous pillars giving an undulate outline to the central thickened region, pillars rather crowded at the center but separating toward the periphery, increasing very rapidly in diameter in the first quarter or third of their length, thence keeping about the same diameter to the surface; lateral chambers in single columns between the pillars; equatorial band of chambers rather narrow and thin, increasing in height toward the periphery.

The horizontal section shows the equatorial chambers to be in general hexagonal, occasionally with the peripheral portion convexly curved; the lateral chambers also hexagonal, 
especially in the contral region, where they are compressed by the pillars.

Diameter as much as 12 or 15 millimeters, but usually less.

Lemoine and R. Douvillé record this species from Italy and Spain. It was noted from the following localities in Cuba:

7512. Ocujal.

7513 (?). Orbitoidal limestone, outcrop where Palmer trail joins Ocujal trail.

7518. South side of Los Melones Mountain near west end.

7519. Orbitoidal limestone from drift near top of landslide next north of Los Melones.

7521. Limestone at top of Mogote Peak.

7522 (?). Mogote Peak.

7543. Limestone outcrop on east side of Yateras River.

7664. North slope of La Piedra, northeast of Jamaica, northeast of Guantanamo, N. H. Darton, collector.

Lemoine and R. Douvillé had only the microspheric form of the species, but the Cuban material contains megalospheric specimens. The embryonic chambers are rather thickwalled and unequal in size.

Lepidocyclina morgani Lemoine and R. Douvillé. Plate XXXIII, figures 12-14.

Lepidocyclina morgani Lemoine and R. Douvillé, Soc. géol. France, Paléontologie, vol. 12, Mém. 32, p.17, pl. 1, figs. 12,15 , 17; pl. 2, figs. 4, 12; pl. 3, fig. 2, 1904 .

Cushman, Carnegie Inst. Washington Pub. 291, p. 59, pl. 11, figs. 1-3, text fig. 7, 1919.

Lepidocyclina cf. L. marginata H. Douvillé, Soc. géol. France Bull., 3d ser., vol. 18, p. 1001, 1900.

Test small, discoidal, much thickened in the central portion, from which it tapers rather rapidly to the subacute periphery; central protuberant portion with a series of large pustules ranging from 5 to 12 or more in number, of which one is usually central; reticulate between, the margins stellate; periphery of the test thin and slightly reticulated by the walls of the equatorial chambers.

Vertical sections show the general form and curvature of the surface of the test, the few pillars in the central region rapidly increasing in diameter toward the surface; lateral chambers with the outer wall convex, averaging about three times as wide as the height in the central region, with as many as 10 chambers in the vertical columns; equatorial chambers not increasing rapidly in height, those at the periphery not more than double the height near the center.

Horizontal sections show the embryonic chambers, which are unequal, the larger one partially surrounding the smaller, as in the subgenus Nephrolepidina of H. Douvillé, and the equatorial chambers more or less diamond shaped also as in that subgenus. In otherspecimens the outer wall of the chamber is convex.

Diameter, 2 to 5 millimeters.

Specimens seemingly identical with this species were found by $\mathrm{O}$. E. Meinzer at the following stations in Cuba:

7513. Limestone outcrop where Palmer trail joins Ocujal trail.

7516. West end of Los Melones Mountain.

7543. Limestone outcrop on east side of Yateras River.

7554. South of El Jigue, 5 miles above mouth of Yateras River on west side.

Specimens probably of this species but sections not as perfect as might be desired were obtained from stations 7519, limestone from drift near top of landslide next north of Los Melones, and 7522, Megote Peak.

Lemoine and R. Douvillé record this species from four localities in Aquitaine-Abesse, Mimbaste, St.-Etienne-d'Orthe, and Le Mandillott; from four localities in Spain-Bacna, Pont du Guadalquivir, Sella, and Peñaguila; and from Madagascar. The stage is indicated as Aquitanian but not definitely given.

It is a very distinctive species and the Cuban specimens seem to differ in no essential characters from those figured by Lemoine and $R$. Dourillé.

Exteriors of specimens from station 7664, north slope of La Piedra, northeast of Jamaica, northeast of Guantanamo, Cuba, are shown in Plate XXXIII, figures 12 and 13.

\section{Lepidocyclina crassata Cushman.}

Plate XXXI, figures $3-6$.

Lepidocyclina crassata Cushman, Carnegie Inst. Washington Pub. 291, p. 61, pl. 11, figs. 4, 5, 1919.

Test of medium size, lenticular, comparatively thick in the center, thence tapering toward the sides; central portion convex, changing to a concave curve toward the periphery; surface irregularly pustulate, especially where somewhat weathered.

The vertical section shows the gencral shape, convex at the center, broadly rounded, thence contracting rapidly toward the periphery, where the curve is concave, to the rather poorly developed peripheral border; height or thickness of the test about one-third the diameter; embryonic chamber large and very thick walled, of ten 
showing one or two accessory chambers also thick walled and rather conspicuously perforate; young specimens show that for a time the embryonic chamber is the greater part of the test; equatorial band of chambers rather large, even at the beginning, the outer wall th convex and coarsely perforate; lateral chambers comparatively thick walled, several times as broad as high, somewhat lenticular in section, highest in the middle, thence tapering toward the sides; a comparatively small number of th pillars in the central part originating in the wall of the embryonic chamber and extending to the surface.

The horizontal section shows the equatorial chambers regularly hexagonal, fairly thick walled, those of various annuli of very different sizes.

Diameter as much as 9 millimeters, maximum height 3 millimeters or more.

The type locality for this species is U. S. G. S. station 7513, orbitoidal limestone, outcrop where Palmer trail joins Ocujal trail, Cuba. Specimens are also numerous in material from stations 7512, Ocujal; 7519, orbitoidal limestone from drift near top of landslide next north of Los Melones; 7521, limestone at top of Mogote Peak.

This is a very heavy, thick-walled species throughout, and in section may be easily distinguished from any of the other Cuban or West Indian species.

Lepidocyclina canellei Lemoine and R. Douvillé.

Plate XXXII, figures 1-5.

Lepidocyclina canellei Lemoine and Douvillé, Soc. géol. France, Paléontologie, Mém. 32, p. 20, pl. 1, fig. 1; pl. 3, fig. 5, 1904.

Cushman, U. S. Nat. Mus. Bull. 103, p. 91, pl. 34, figs. 1-6, 1918.

Test comparatively small, diameter of largest specimens slightly less than 4 millimeters, thickness a little more than one-fourth the diameter; circular in outline, central portion somewhat raised and evenly rounded, near the periphery flattened or even slightly concave; surface in well-preserved specimens finely granular or even finely papillate but not strongly so, often appearing smooth to the unaided eye. In worn specimens the surface appears as a series of regular hexagonal, honeycomb-like reticulations due to the edges of the lateral chambers.
In vertical section the lateral chambers are seen to be arranged in vertical columns, one directly above another, from the equatorial chambers to the surface, about 12 chambers in each vertical column in the central region, the lateral walls hardly thicker than the upper or lower surfaces. Chamber of adjacent columns arranged alternately; no distinct columns present. Equatorial chambers gradually increasing in size toward the periphery, single throughout, extending peripherally beyond the lateral chambers and in surface view in wellpreserved specimens appearing as a hexagonal reticulation. Embryonic chambers nearly equal in size, nearly semicircular in section, their common wall straight.

The horizontal section shows the equatorial chambers regularly hexagonal; those toward the periphery the largest. Embryonic chambers similar to those shown in the vertical view. Lemoine and R. Douvillé described and figured this species from Peñablanca, Panama, and also noted it from Martinique and Angola. The material from Panama recorded by Dall and by Bagg ${ }^{1}$ as Orbitoides forbesi Carpenter (catalogue No. 135216, U.S. N. M.) is Lepidocyclina canellei Lemoine and R. Douvillé. Figures $1,3,4$, and 5 in Plate XXXII are from material collected by Hill at Bohio, Panama, where it is very abundant. This is the same station as 6027 of Vaughan and MacDonald (orbitoidal marl, a quarter of a mile northwest of Bohio railroad station). In this material L. canelle $i$ is very abundant and makes up a considerable proportion of the marl.

Specimens in the collection of the U.S.N. M. (catalogue No. 107158) from the Oligocene of of Trinidad (Leda bed, Naparina), collected by Guppy, are also very evidently Lepidocyclina canellei.

Specimens of $L$. canelle $i$ were very abundant at station 6891, foraminiferal limestone at Balamonas, Canal Zone, where they were collected by D. F. MacDonald.

A limestone at station 6892,450 feet south of switch at Mamei, Canal Zone, contains numerous specimens also collected by MacDonald, of a Lepidocyclina which in general shape in section resembles $L$. canellei, but the material is very cherty and the finer structure is not well preserved.

1 Hill, R. T., The geologic history of the Isthmus of Panama: Harvard Coll. Mus. Comp. Zool. Bull., vol. 28, pp. 272, 275, 1898. 
A few small weathered specimens from station 6019a, Gaillard ('ut, opposite Las Caseadas, and from station 6023, along the relocated line of the Panama Railroad at Rio Frijol, seems to belong to this species also. They occur in the Culebra formation.

\section{Lepidocyclina canellei Lemoine and R. Douvillé var. yurnagunensis Cushman.}

Plate XXX1I, figures 6, 7; Plate XXX1I1, figures 1-9.

Lepidocyclina canellei Lemoine and R. Youvillé var. yurnagunonsis Cushman, Carnegie Inst. Washington Pub. 291. p. 57, pl. 12, figs. 7,8 , text figs. 6a, 6b. 1919.

Test differing from the typical form of the species mainly in the form of the lateral chambers, which are somewhat broader and with the upper wall decidedly arched; embryonic chambers either two, subequal or very unequal, or several, the equatorial chambers hexagonal or obscurely diamond shaped.

Type material from U. S. G. S. station 7548, flexure 2 miles south of Yurnaguna, Cuba; collected by O. E. Meinzer.

At this station the material is composed largely of this species, as is shown by the section in Plate XXXII, figure 7 . None of these sections happens to be exactly vertical. The variety shows the embryonic characters of all three of H. Douvillé's subgenera-equal chambers, as in the type from Panama, Isolepidina (Pl. XXXIII, fig. 4); unequal, one small, the other partly encircling and kidney shaped, as in Nephrolepidina (Pl. XXXIII, figs. 5-8); and with two irregular large embryonic chambers and two or more small ones, as in Pliolepidina (Pl. XXXIII, fig. 9). The last-mentioned condition is also shown in Plate XXXII, figure 6.

In gross appearance, color, and general characters this material very strikingly resembles that from Bohio, Panama, the type locality for $L$. cancllei.

Specimens of this rariety seem to be present in the Antiguan material from Hodges Bluff (U. S. G. S. station 6862) and Rifle Butts (L. S. G. S. station 6854).

Other Cuban localities are stations 7516, west end of Los Melones Mountain, and 7543, limestome on the east side of Yateras River; O. E. Meinzer, collecter.
Lepidocyclina sumatrensis (H. B. Brady) Jones and Chapman.

Plate XXXIII, figures 10, 11.

Orbitoides sumatrensis H. B. Brady, Geol. Mag., 2d ser., vol. 2, p. 536, pl. 14, fig. 3, 1875; Jaarb. Mijn. Ned. Oost.-Indii, vol. 7, pt. 2, p. 165, pl. 2, fig. $3,1878$.

Newton and Ilolland, Ann. and Mag. Nat. Hist., 7th ser., vol. 3, p. 259, pl. 10, figs. 7-12, 1899.

Lepidoeyclina sumatrensis Jones and Chapman, in Andrews, A monograph of Christmas Island, London, p. 244, pl. 20, fig. 6, 1900 .

Newton and Ilolland, Tokyo Coll. Sci. Jour., vol. 27, art. 6, p. 11, pl. 1, fig. 7, 1903.

Lemoine and R. Donvillé, Soc. géol. Fra nce, Paléon tologie, vol. 12, Mém. 32, p. 18, pl. 1, fig. 14; pl. 2, fig. 15 ; pl. 3 , fig. $6,1904$.

Cushman, Carnegie Inst. Washington Pub. 291, p. $60, \mathrm{pl} .12$, figs. 3, 4, 1919.

Test small, discoidal, thickened in the central portion, from which it tapers gradually to the subacute periphery; central protuberant portion more or less pustulate throughout, but these protuberant spots of small size and covering the larger part of the area more or less evenly; surface otherwise smooth; periphery thin.

Vertical sections show the general form and curvature of the test, pillars entirely lacking, lateral chambers with the outer surface conrex, three or four times as wide as high; 6 to 10 chambers in a rertical column.

Iorizontal sections show the embryonic chambers, which are unequal, the larger curved about the smaller semicircular one; equatorial chambers irregularly hexagonal or lozenge shaped.

Diameter, 2 to 5 millimeters.

$L$. sumatrensis has been found in Cuba at the following stations:

7513. Limestone outcrop where Palmer trail joins Ocujal trail; O. E. Meinzer, collector.

7516. Tiest end of Los Melones Mountain: O. E. Meinzer, collector.

7519. Liniestone from drift near top of landslite next north of Los Melones; O. E. Meinzer, collector

7543. Limestone outcrop on east side of Yateras River; O. E. Meinzer, collecter.

7554. South of El Jigue, 5 miles alove mouth of Yateras River, on west side; O. E. Meinzer, collector.

7664. North slope of La Pierlra, northeast of Jamaica, northeast of Guantanamo; N. II. Darton, collector.

This species was described by Brady from Sumatra. It is recorded elsewhere in the east from Formosa and the East Indies, and Lemoine and $R$. Douvillé record it from Italy, Spain, and France. 
In Cuba it occurs usually in company with $L$. morgani, and in this connection it is interesting to note that both species are listed by Lemoine and R. Douville from all four of the stations in Spain and from three of the four stations in France.

This species may easily be distinguished from $L$. morgani by its lack of pillars. The pustulate appearance of $L$. sumatrensis is due to the convex surface of the lateral chambers, those of adjacent columns being of unequal height at the surface. A figure, evidently of this species, by Miss O'Connell ${ }^{1}$ shows a vertical section at the left. The specimen came from a limestone quarry at Arroyo Seboruco, 12 miles from Felton, Cuba.

\section{Lepidocyclina macdonaldi Cushman.}

Plate XXXIV, figures 1-3.

Lepidocyclina macdonaldi Cushman, U. S. Nat. Mus. Bull. 103, p. 94 , pl. 40, figs. 1-6, 1918.

Test circular, rather small, about 5 to 7 . millimeters in diameter, thickest in the central region, thence gradually sloping to the periphery, which for a short distance in from the edge is nearly flat; wall rather smooth except the central portion of the umbonal region, which has a few pustule-like raised spots at the surface ends of the vertical pillars.

The vertical section shows the test widest in the middle, gently sloping nearly to the periphery, edges nearly parallel for a short distance to the peripheral edge or even slightly increasing in thickness. Lateral chambers in the central portion in definite vertical columns, occasionally slightly overlapping. Equatorial chambers not increasing very rapidly in height in megalospheric specimens, those at the periphery hardly more than double the height of those near the center of the test. Embryonic chambers in the megalospheric form large, usually of two nearly equal chambers, but in oblique cutting these may appear somewhat unequal. (See Pl. XXXIV, fig. 2.)

Horizontal sections show chambers somewhat similar to those of $L$. vaughani but with the inner half of two walls at nearly right angles, the outer wall broadly rounded. The oblique section (Pl. XXXIV, fig. 3) shows the pillars.

The type locality for this species is U. S. G. S. station 6523 , orbitoidal limestone

J Kemp, J, F., Am. Inst. Min. Eng. Trans., rol. 51, fig. 6, 1916.
2 miles north of David, Panama, collected by D. F. MacDonald, Specimens were abundant at this station, occurring with $L$. panamensis and L. multiplicata.

\section{Lepidocyclina panamensis Cushman.}

Plate XXXIV, figures 4-6.

Lepidocyclina panamensis Cushman, U. S. Nat. Mus. Bull. 103, p. 94, pl. 39, figs. 1-6; pl. 42, 1918.

Test circular, small; central portion very strongly umbonate, thick, rapidly decreasing in thickness peripherally; peripheral portion thin and flattened; the raised central portion only one-third to one-fifth the entire diameter, which ranges from 3 to 6 millimeters, with occasional specimens, perhaps representing the microspheric form, 10 or 12 millimeters in diameter; surface smooth except for the umbonal portion, which has a few large pustulelike projections marking the ends of the internal pillars.

The vertical section shows very peculiar embryonic chambers, not the usual type for American species, but with a broad and much flattened central chamber two to four times as broad as high and a compressed, partly encircling chamber, in section usually cut on the opposite sides of the central chamber. These central chambers in section are nearly as wide as the whole umbonal portion of the test. In some specimens there seems to be an irregular mass of three or four more or less nearly spherical chambers. Lateral chambers usually about twice as wide as high, the outer wall often somewhat arched toward the exterior of the test, arranged in vertical columns. Pillars not distinct except in the central portion, where there are a few strong ones increasing rather rapidly in diameter toward the periphery, usually about 9 or 10 chambers in a vertical column in the center of the umbilical region. The peripheral region has but a thin coating of lateral chambers, the last-formed layer present only on the outer half of the periphery and often none at all present on the last quarter of the test toward the periphery, the surface being made up by the upper and lower walls of the equatorial chambers. Equatorial chambers numerous, comparatively broad, the peripheral wall convex outward toward the periphery, the chambers at least as wide as high.

In horizontal section the equatorial chambers appear usually somewhat irregularly hexagonal 
near the center, more or less rhomboid toward Lézard, St. Bartholomew; T. W. Taughan, the periphery, with the onter peripheral wall curvel.

So far as deseribed material is concerned this is an untsual form for Imerican species of Lepidocyctina, especially in its embryonie chambers.

Type specimen, rertical sections (U. S. N. M. catalogue No. 324741). The species is fairly abundant at stations $6586 \mathrm{P}$ and 6587 , neal the mouth of Tonosi River, Panama: D. F. MacDonald, collector. It was also collected by MacDonald at station 6512 , in the river bed at Darid, Panama.

\section{Lepidocyclina antillea Cushman.}

Plate XXXV, figures 4, 5.

Lepidocyclina antillea Cushman, Carnegie Inst. Washington Pub. 291, p. 63, pl. 3, fig. 3, 1919.

Test compressed, eircular, rather evenly biconvex, lenticular; central portion highest, thence gradually thinning toward the periphery: central area strongly papillate: remainder of the surface less strongly so.

The rertical section shows equatorial chambers increasing in height toward the periphery, those of the central region measuring less than 0.1 millimeter, those of the periphery as much as 0.5 millimeter in height: outer wall of the equatorial chambers very squarely truncated.

Lateral chambers not numerous, in the central thickened region only 6 or 7 chambers in a column, and this number is gradually reduced toward the periphery. Central region and whole test in lesser degree marked by rery heary and numerous pillars, greatest width near the outer end, thence gradually tapering toward the center: outer ends rounded, forming the papillae of the surface. In the central region the surface area occupied by the pillars is greater than that taken up by the lateral chambers.

In horizontal seetion, or at least in the somewhat broadly oblique section, the equatorial chamber's are of the eurved Lepidocyclina form instear of the more typical hexagonal shape.

Diameter of test averages about 5 millimeters.

The type locality for this species is U. S. G. S. station 6897, conglomerate and sandstone below upper limestone bed, Anse Ecaille side of point between Anse Ecaille and Anse

collector. Material apparently weathered out from the matrix is abundant here and also at station $6897 b$, point between Colombier Point and bay next to St. Jean Bay, St. Bartholomow; T. W. Vaughan, collector. Hand specimens showing sections of this heary-pillared species were abundant in a hard, cherty material at stations 6902 , in the southeast section of the southwest side of the island near Negre Point, St. Bartholomew, at an elevation of 360 feet, and 6903, N. $67^{\circ}$ E. from summit of Negre Point across low sadelleback of point, at an altitude of 220 feet.

This species is related in many ways to Lepidocyclina macdonaldi Cushman, from the white limestone at Darid, Panama. The general rertical section is much more heavily pillared in $L$. antillea, although the figure, not being exactly central, shows this much less strongly than many of the weathered sections in hand specimens. The material from the white limestone at Darid, Panama (U. S. G. S. station 6512), referred to as $L$. panamensis, may belong to $L$. antillea, and also the sections resembling $L$. macdonaldi.

\section{Lepidocyclina duplicata Cushman.}

Plate XXXV, figures 1-3.

Lepidocyclina duplicata Cushman, U. S. Nat. Mus. Bull. 103, p. 96, pl. 41, figs. 2-4. 1918.

Test of medium sıze, 10 to 14 millimeters in cliameter, rery much thickened in the umbonal region, usually the thickness about onehalf the diameter, central portion without the flattened periphery, subspherical, thinning rapidly toward the periphery, then thickening again at the margin, which is doubly plicate in some of the best-preserved specimens. Surface of the umbonal portion studded with numerous fine papillae marking the surface terminations of the pillars; peripheral portion nearly smooth.

The rertical section shows the embryonic chambers as very small, apparently microspheric in the specimens sectioned, appearing spiral, as is usual in the microspheric form. Lateral chambers numerous, flattened or lenticular, the numerous pillars as wide as or wider than the intermediate columns of chanbers, especially in the central portion; rapidly increasing in size toward the surface. Equa- 
torial chambers very small near the center, gradually increasing in size toward the periphery, where they become multiple instead of single, as is usually the case, and make three or four vertical series, each with numerous fine apertural pores on the outer convex wall.

The horizontal section shows the increase in size of the equatorial chambers, which toward the center seem hexagonal and toward the periphery almost rhomboid, with the outer half convex.

Of somewhat similar character in respect to the duplication of equatorial chambers are $L$. multipartita (Martin), from Java, and $L$. insulæ natalis var. inequalis (Jones and Parker), from Christmas Island.

Type specimen, U. S. N. M. catalogue No. 324742. Specimens were very abundant, weathered out of an orbitoid limestone, 2 miles north of David, Panama; D. F. MacDonald, collector. They occur also with other species of Lepidocyclina at station $6586 e$, near the mouth of Tonosi River; D. F. MacDonald, collector.
Lepidocyclina kempi (O’Connell) Cushman.

Orbitoides kempi O'Connell, Am. Inst. Min. Eng. Trans., vol. 51, p. 13, figs. 5, 6, 1916.

Under the name Orbitoides kempi Miss O'Comell figured sections from a limestone quarry at Arroyo Seboruco, 12 miles from Felton, Cuba. Although the description is not very clear, the figured section (fig. 5) shows the species to belong to the genus Lepidocyclina. Measurements given are, total diameter, $7+$ millimeters; central thickness, 2.5 millimeters. The general characters that can be made out from the description and figures would seem to indicate that it may very probably be $L$. marginata (Michelotti). This suggestion is strengthened by the fact that in figure 6 appears a vertical section, very evidently of L. sumatrensis Brady, a species, so far as seen in the Cuban material I have examined, occurring with $L$. marginata in four out of eight stations. I have refrained from placing this definitely as a synonym of $L$. marginata until specimens are available for comparison. 



\section{PLATES XII-XXXV.}


PLATE XII.

\section{Lepidocyclina mantelli (Morton) Giimbel (p. 57).}

Figure 1. Surface view, $\times 2$, megalospheric form. St. Stephens Bluff on Tombighee River, Ala. (IT. S. G. S. station 298 ).

Figure 2. Surface view, $\times 2$, microspheric form. West hank of Conecuh River at bend abont a quarter of a mile below mouth of Sepulga River, Escambia County, Ala. (U. S. G. S. station 671S).

Figure 3 . Surface view, $\times 2$, microspheric form. 7 miles west of ('laiborne, 2 miles east of Howards Landing, Monroe County, Ala. (U. S. G. S. station 2397).

Figure 4. Transverse section, $\times 10$, showing the very slight increase in the height of the equatorial chambers. Limestone 6 miles southeast of Shubuta, on (arson Creek, Miss. (U. S. G. S. station 2636).

Figure 5. Transverse section, $\times 15$. North side of Salt Mountain, 5 miles south of Jackson, Clarke County, Ala. (U. S. G. S. station 3296). 

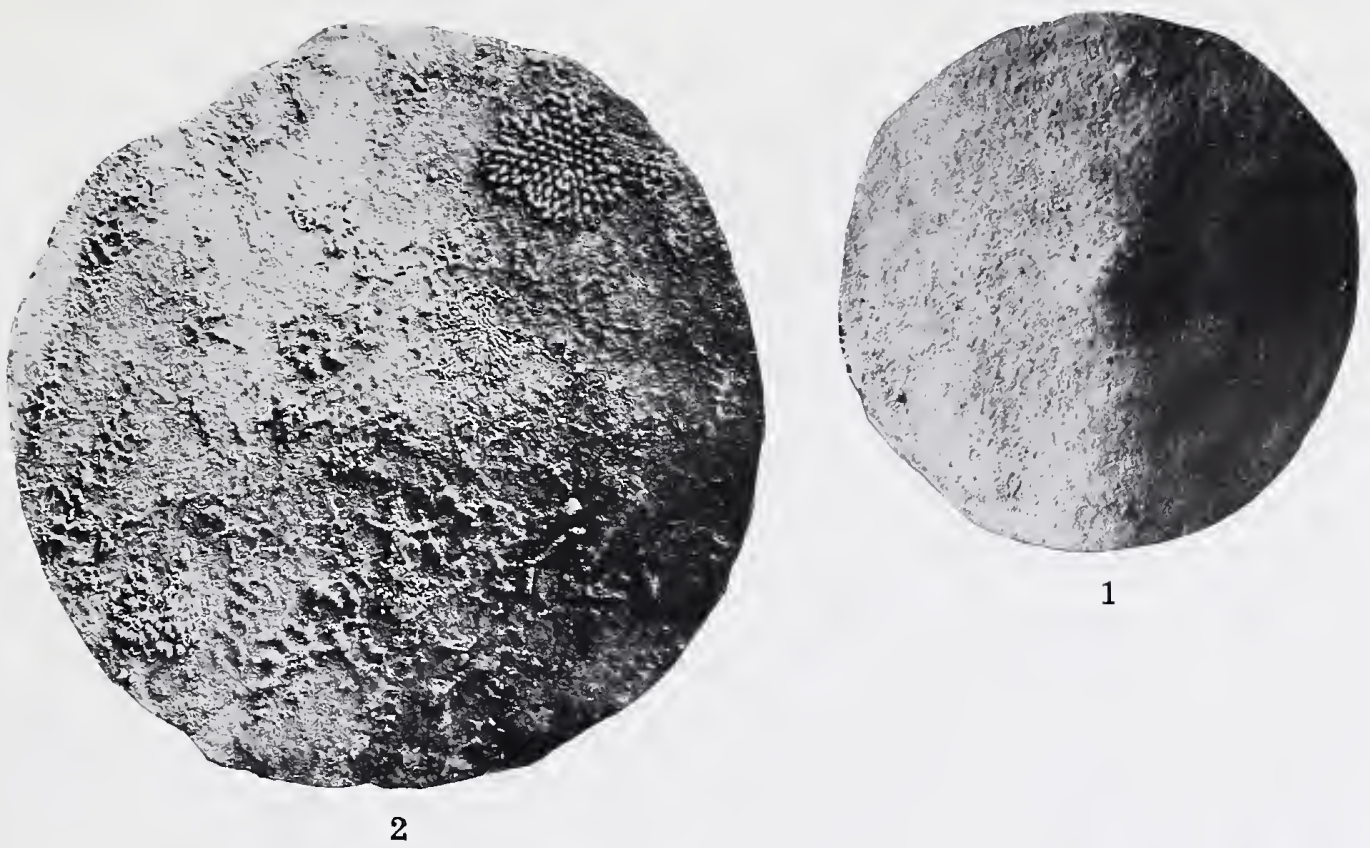

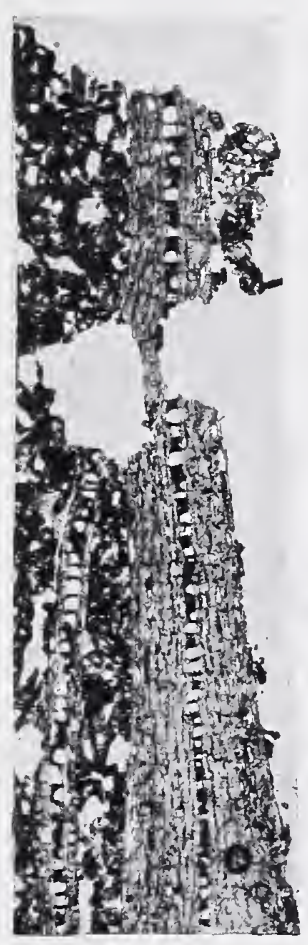

5

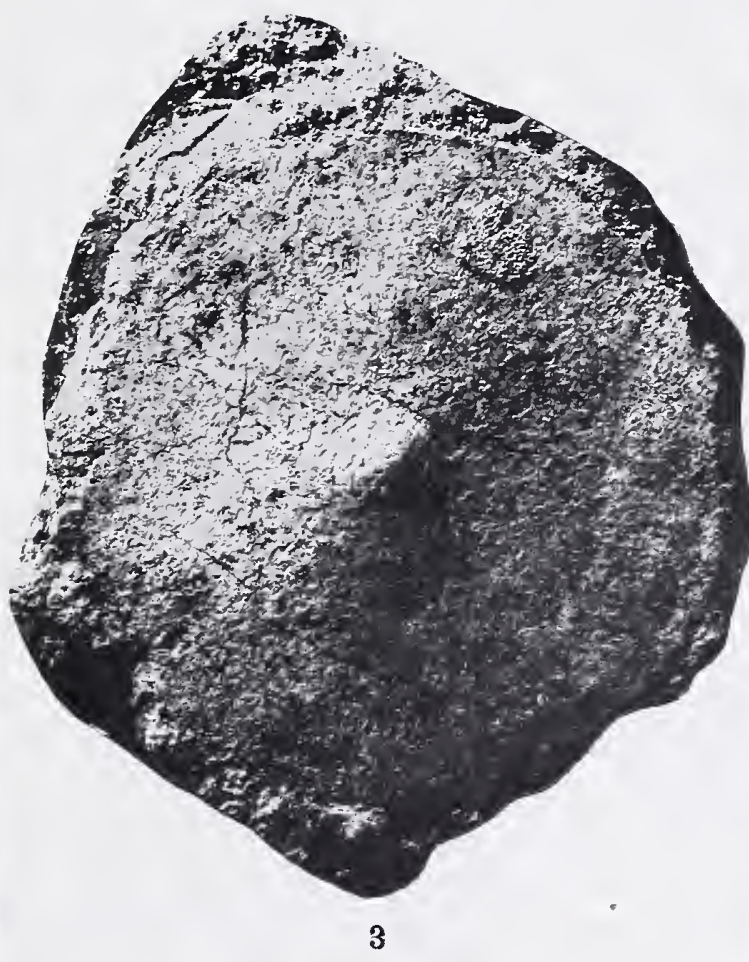

AMERICAN SPECIES OF LEPIDOCYCLINA.

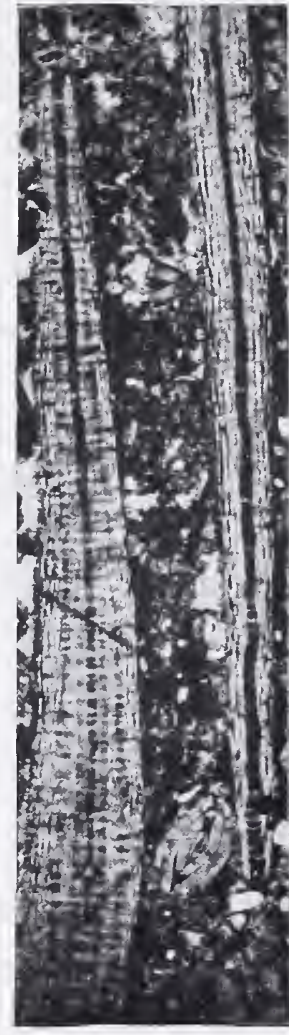

4 


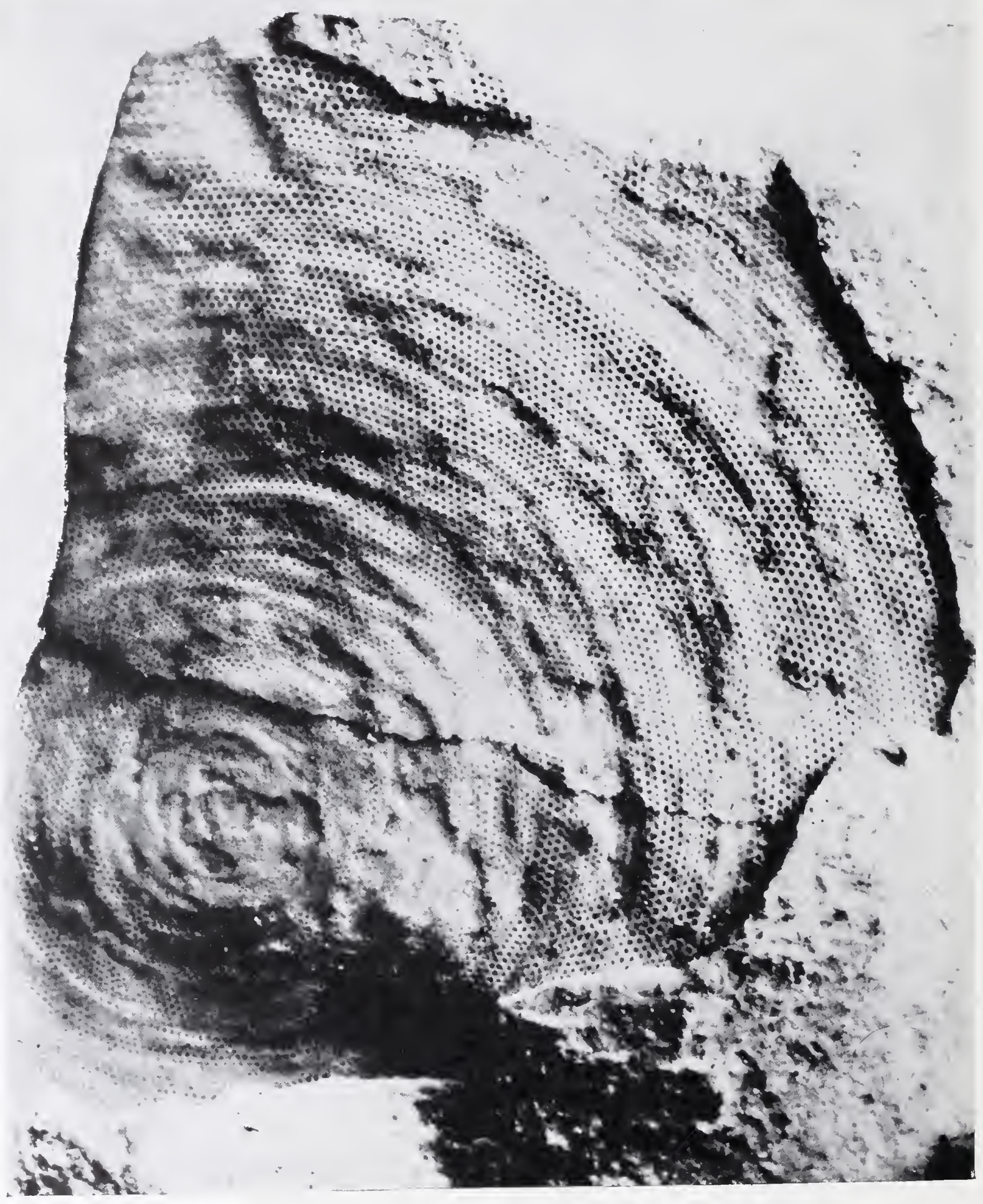

AMERICAN SPECIES OF LEPIDOCYCLINA 


\section{PLA'TE XIII.}

Lepidocyclina mantelli (Morton) Gümbel (p. 57).

Accidental section of microspheric specimen, $\times 9$, showing the equatorial chambers and the irregular width of the annuli. White limestone 2 miles southwest of Whatley Station, Clarke County, Ala. (U. S. G. S. station 2956). 


\section{PLATE XIV.}

Lepidocyclina mantelli (Morton) Gümbel (p. 57).

Figure 1. Accidental section as in Plate XIII, with the central chambers of the microspheric form, $\times 18$ (I.S.G.S. station 2956).

Figure 2. Accidental section of megalospheric form, $\times 9$, showing the two subequal embryonic chambers. Same locality as figure 1. 

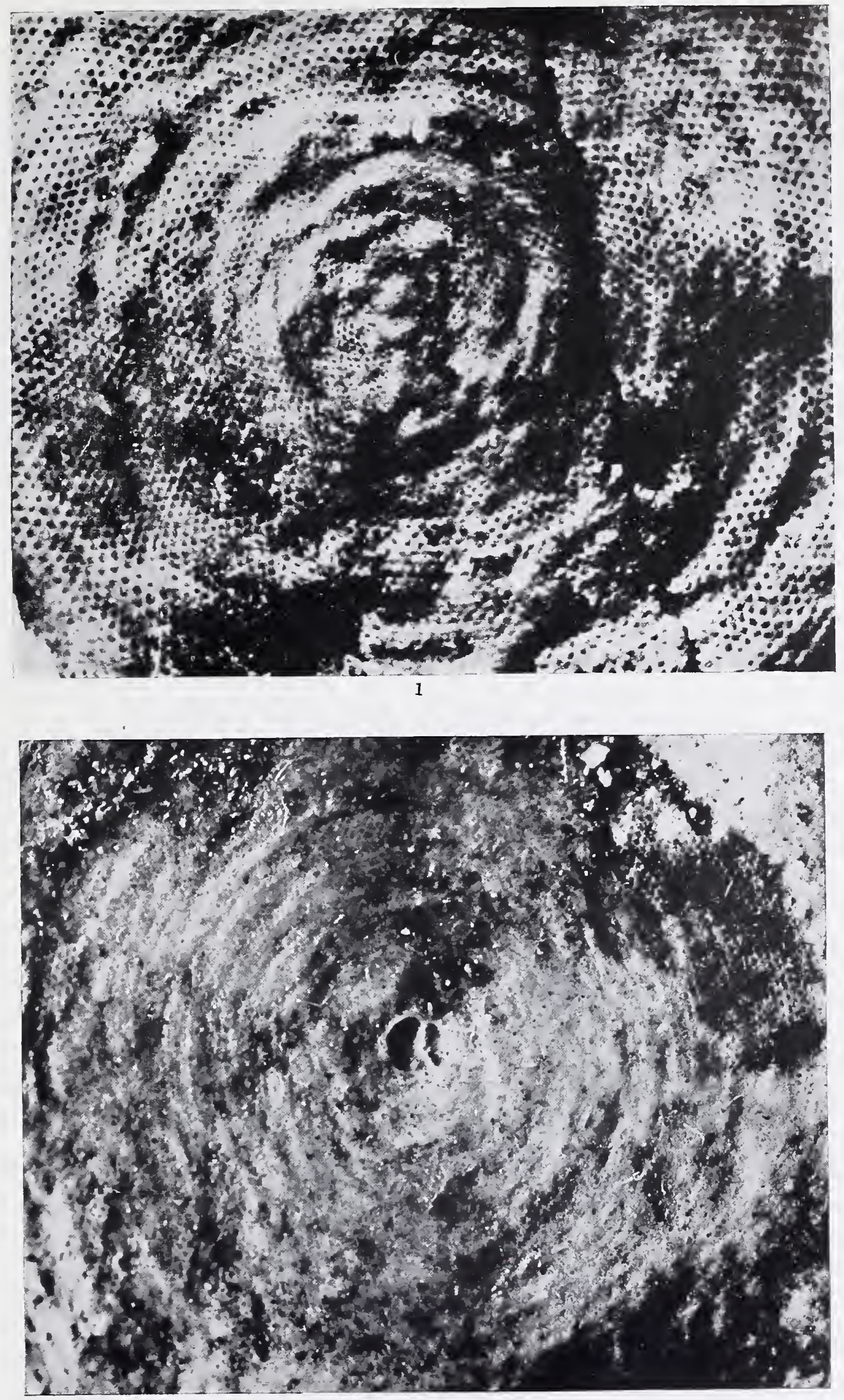

2

AMERICAN SPECIES OF LEPIDOCYCLINA. 


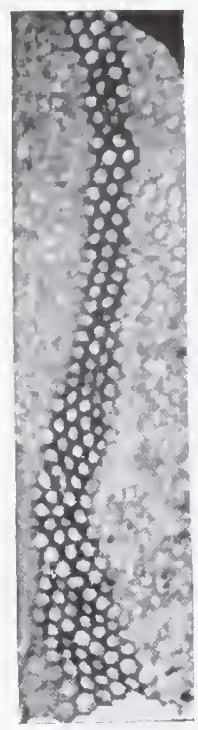

2
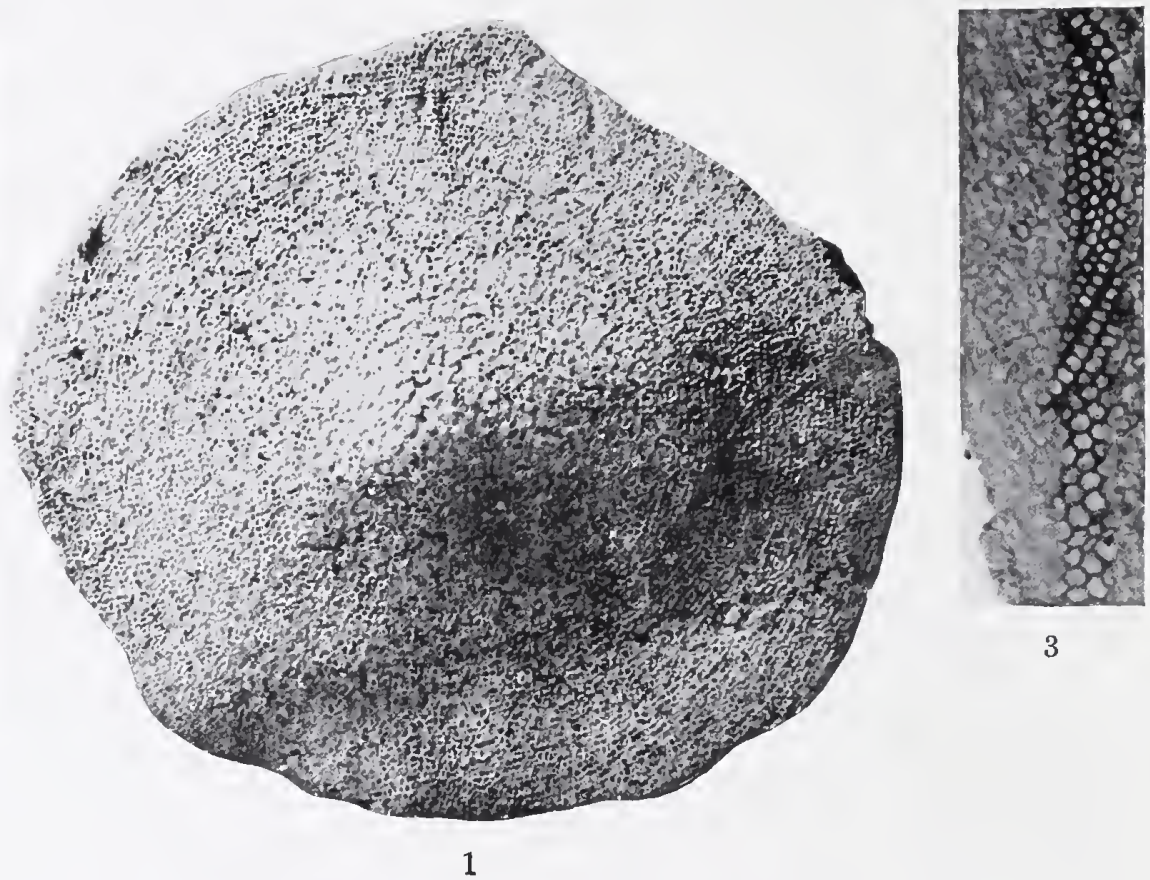

3
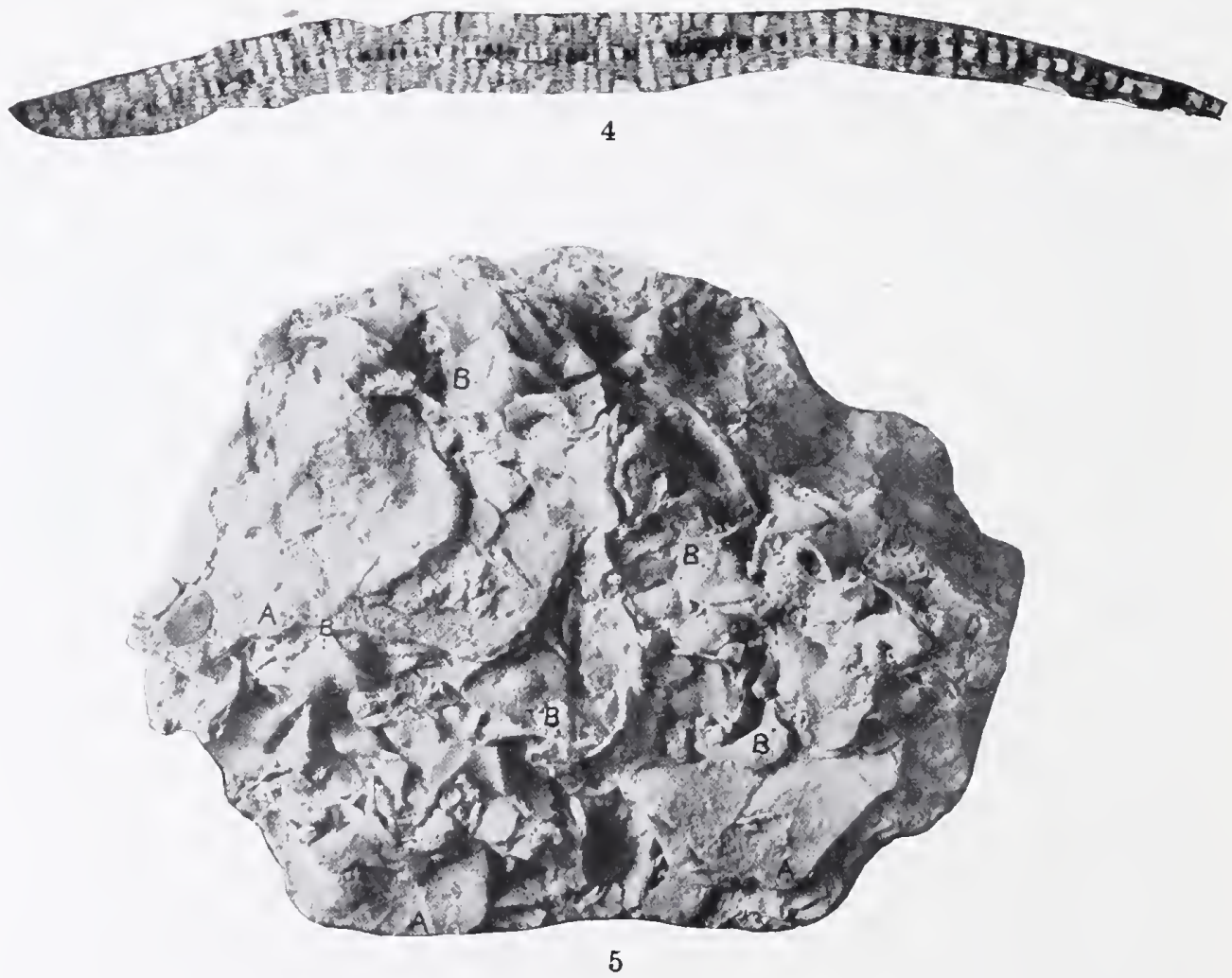

AMERICAN SPECIES OF LEPIDOCYCLINA. 
PLATE XV.

\section{Lepidocyclina hilli Cushman n. sp. (p. 60).}

Figure 1. Surface view of type specimen, $\times 5$, from the Guallava sandstone of Costa Rica (U. S. N. M. No. 135220).

\section{Lepidocyclina undulata Cushman (p. 60).}

Figure 2. Portion of section showing the equatorial chambers, $\times 20$, from lower bed at Hodges Bluff, Antigua, Leeward Islands (U. S. G. S. station 6862).

Figure 3. Similar section, $\times 20$, from Rifle Butts, Antigua, Leeward Islands (U. S. G. S. station 6854).

Figure 4. Vertical section, $\times 20$ (U. S. G. S. station 6862).

Figure 5. Rock specimen, natural size, largely made up of Lepidocyclina undulata (A) and L. favosa (B). Bluffs on north side of Willoughby Bay, Antigua, Leeward Islands (U. S. G. S. station 6881). 


\section{PLATE XVT.}

Lepidocyclina georgiana Cushman, n. sp. (p. 60).

Flgure 1. Vertical section, $\times 15$, showing the pillars of the central portion. Ocala limestone, east bank of Flint River 6 iniles above Bainbridge, Ga. (U. S. G. S. station 7130).

Lepidocyclina hilli Cushman, n. sp. (p. 60).

Figure 2. Surface view of type specimen, $\times 15$, showing the reticulate character of the exterior with the few pillars of the central portion. Cuallava sandstone of Costa Rica. 

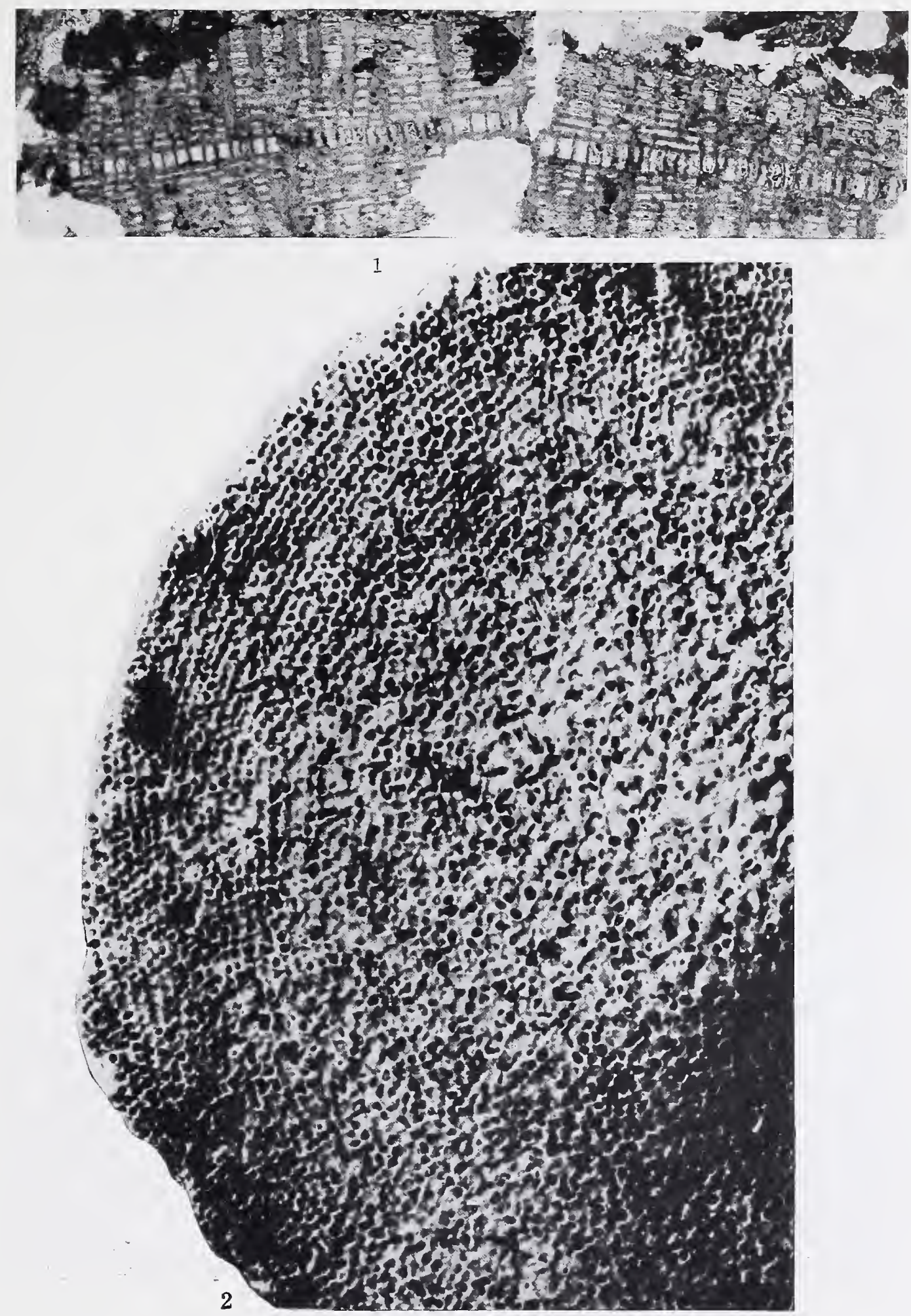

AMERICAN SPECIES OF LEPIDOCYCLINA. 

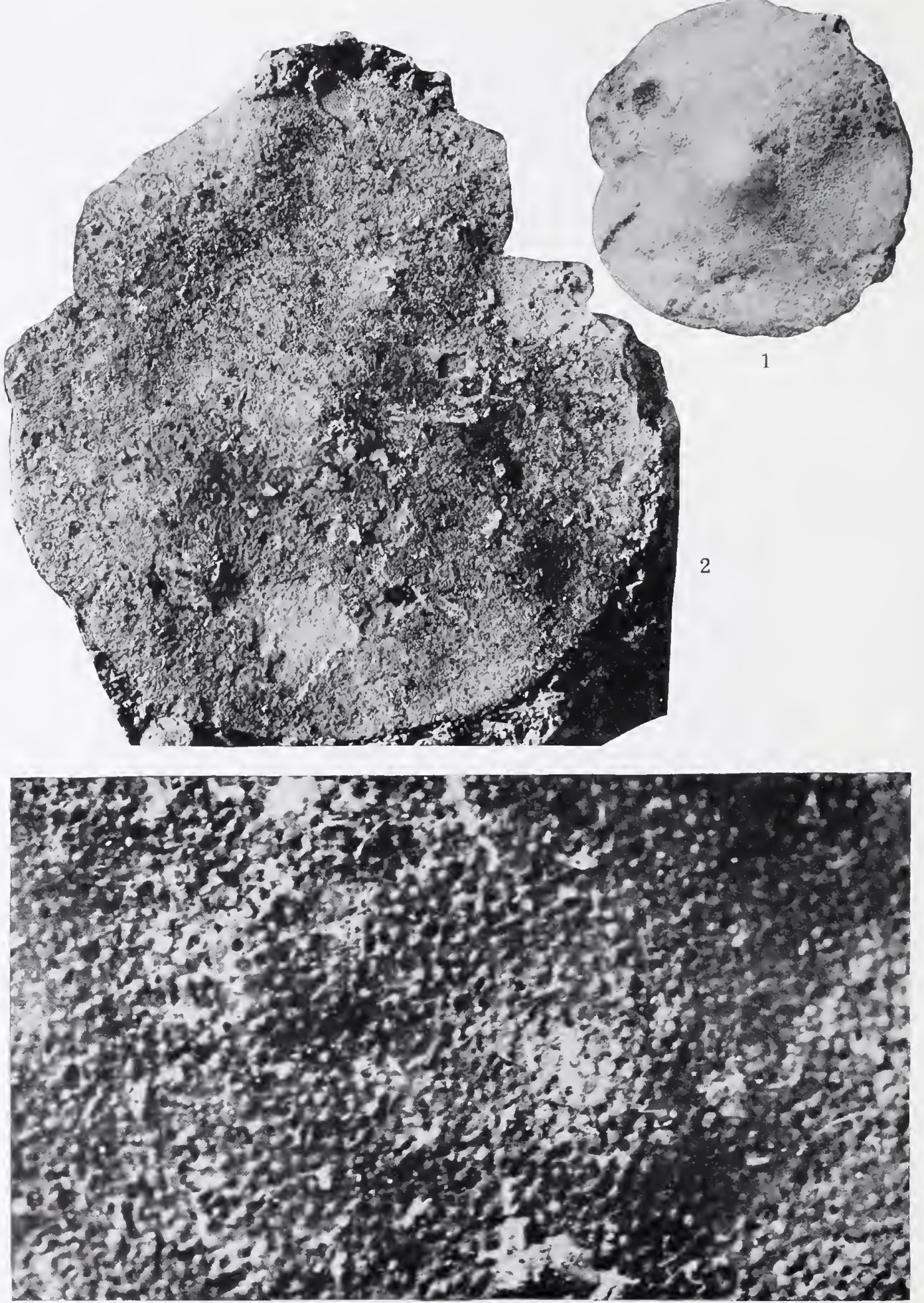

AMERICAN SPECIES OF LEPIDOCYCLINA. 


\section{PLATE XVII.}

Lepidocyclina georgiana Cushman, n. sp. (p. 60).

Flg URE 1. Surface view of megalospheric specimen, $\times 2$. Higher umbo than in larger microspheric specimen (fig. 2). Ocala limestone, east bank of Flint River 6 miles above Bainbridge, Ga. (U. S. G. S. 7130).

Figure 2. Surface view of microspheric specimen, $X 2$. Ocala limestone.

FlGURE 3. Surface details of umbonal portion, $\times 10$. Ends of pillars appear as pustule-like projections. Ocala limestone, Red Bluff, on Flint River 7 miles above Bainbridge, Ga. (U. S. G. S. station 3387). 


\section{PLATE XVIII.}

\section{Lepidocyclina georgiana Cushman, n. sp. (p. 60).}

FlGURE 1. Peripheral portion of specimen showing the surface ornamentation and near the edge the section of the equatorial chambers, $\times 10$. Flint River, Bainbridge, Ga. (U. S. G. S. station 6161).

Figure 2. Very large specimen, exterior, $\times 2$, showing the umbo and in places the equatorial chambers. Ocala limestone at Red Bluff, on Flint River 7 miles above Bainbridge, Ga. (U. S. G. S. station 3387). 

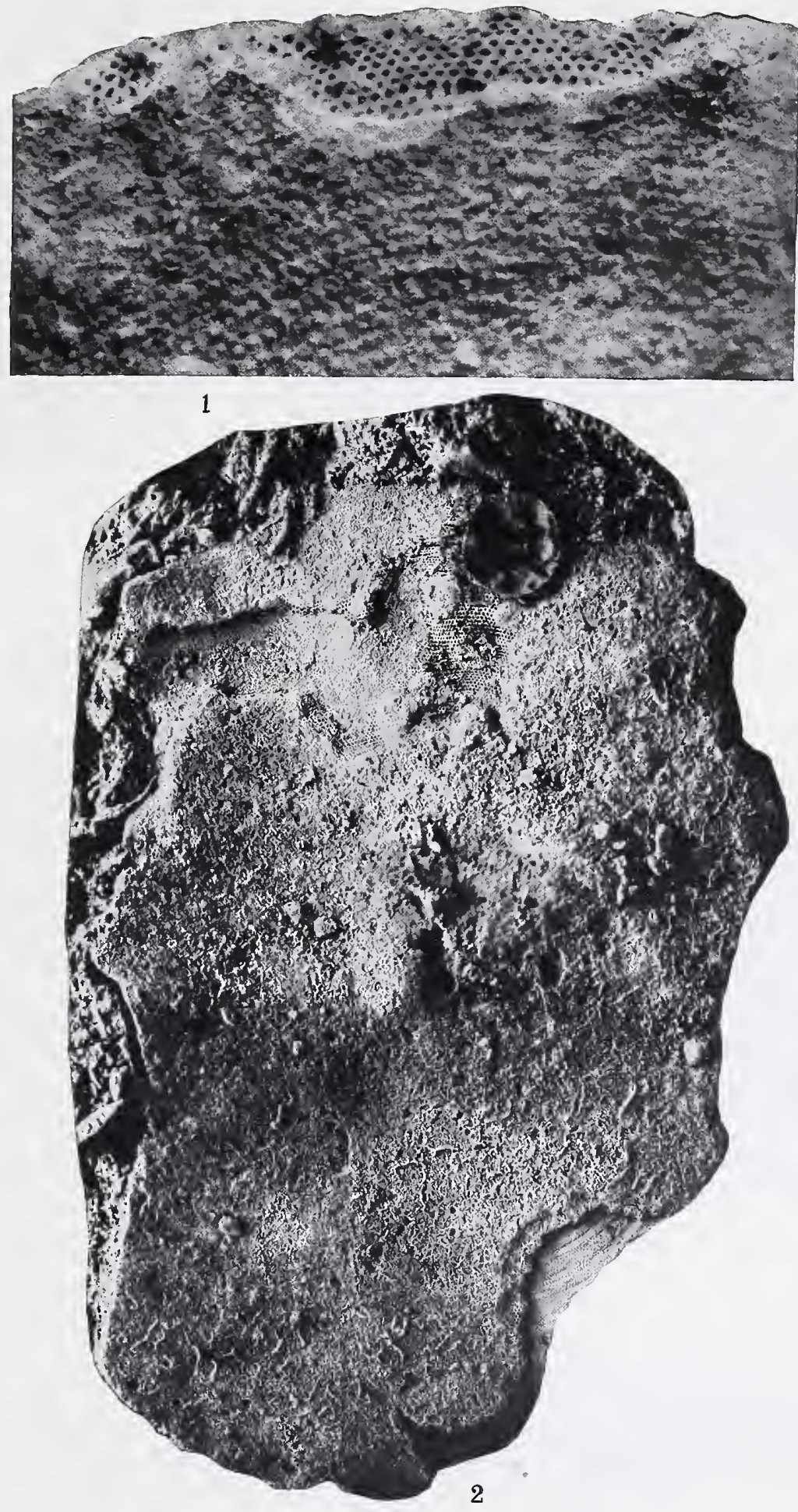

AMERICAN SPECIES OF LEPIDOCYCLINA. 

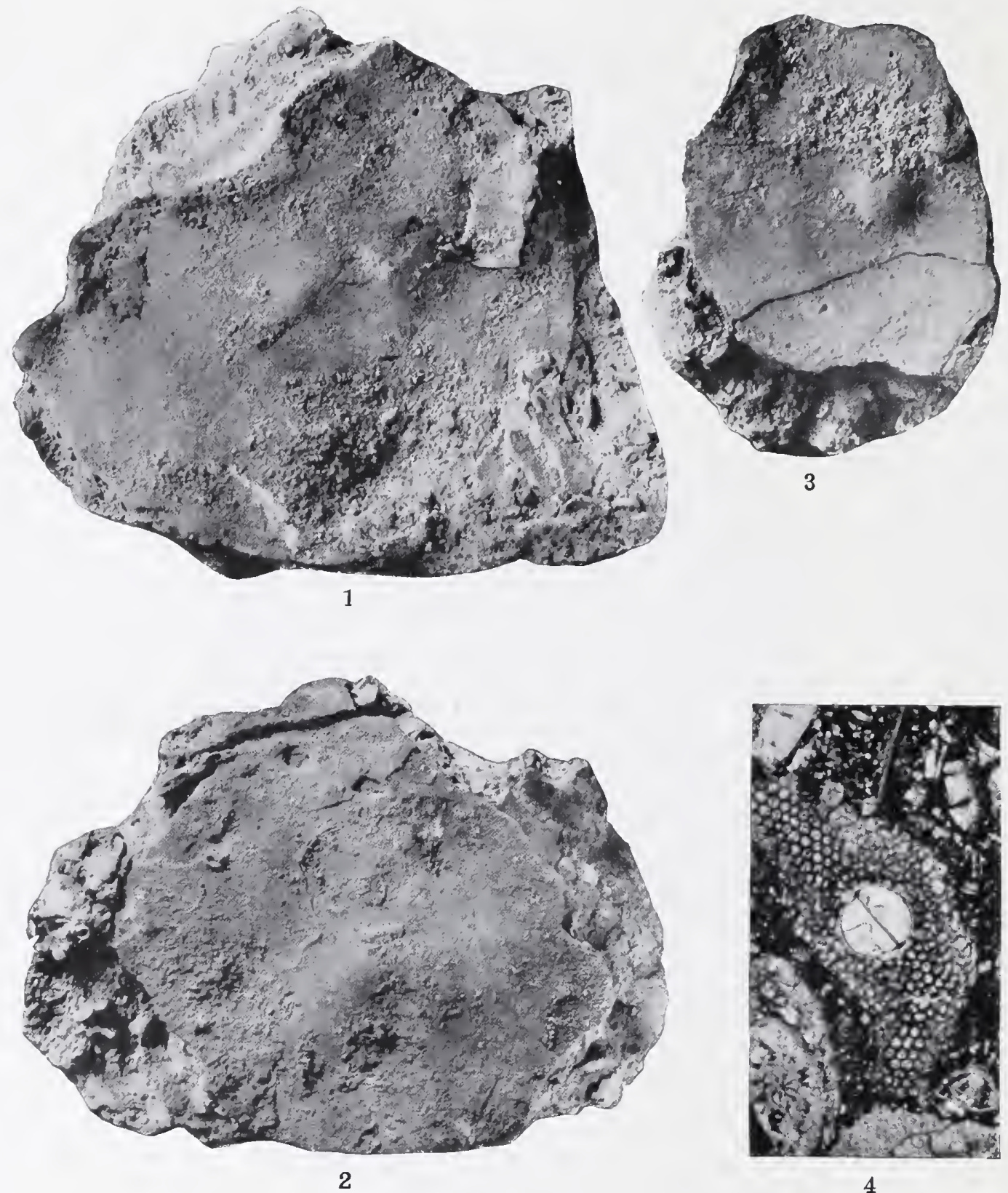

4

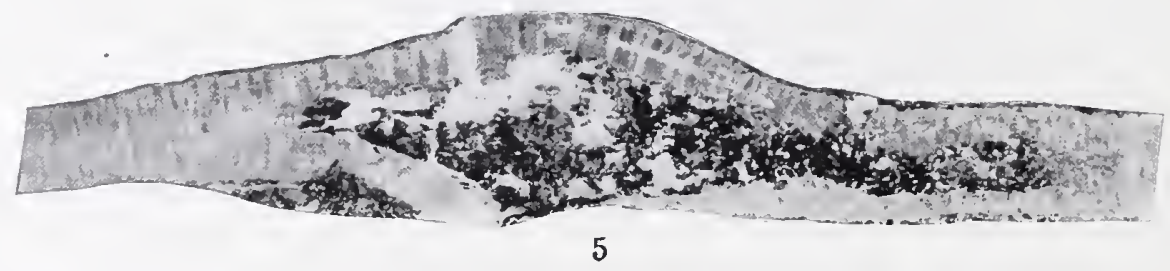

AMERICAN SPECIES OF LEPIDOCYCLINA. 


\section{PLATE XIX.}

\section{Lepidocyclina gigas Cushman (p. 63).}

FIgUREs 1, 2. Surface views of microspheric specimens, with the umbonal portion not greatly raised, natural size. Lower bed, Hodges Bluff, Antigua, Leeward Islands (U. S. G. S. station 6862).

Figure 3. Surface view of megalospheric specimen with prominent umbo, natural size. Same locality as figures $1,2$. Figure 4 . Section showing the subequal embryonic chambers and the hexagonal equatorial chambers, $\times 20$. Rifle Butts, Antigua, Leeward Islands (U. S. C. S. station 6854).

Lepidocyclina gigas var. mexicana Cushman, n. var. (p. 63).

Figupe 5. Transverse section, $\times 5$. Meson formation, Meson, Vera Cruz, Mexico. $131049^{\circ}-20-8$ 


\section{PLATE XX.}

Lepidocyclina gigas var. mexicana Cushman, n. var. (p. 63).

Figure 1. Surface view of type specimen, $\times 2$. Meson formation, Meson, Tera Cruz, Mexico.

Figure 2. Surlace view of portion of same specimen, $\times 15$, showing pitted, reticulate pattern produced by the erosion of the suriace. 

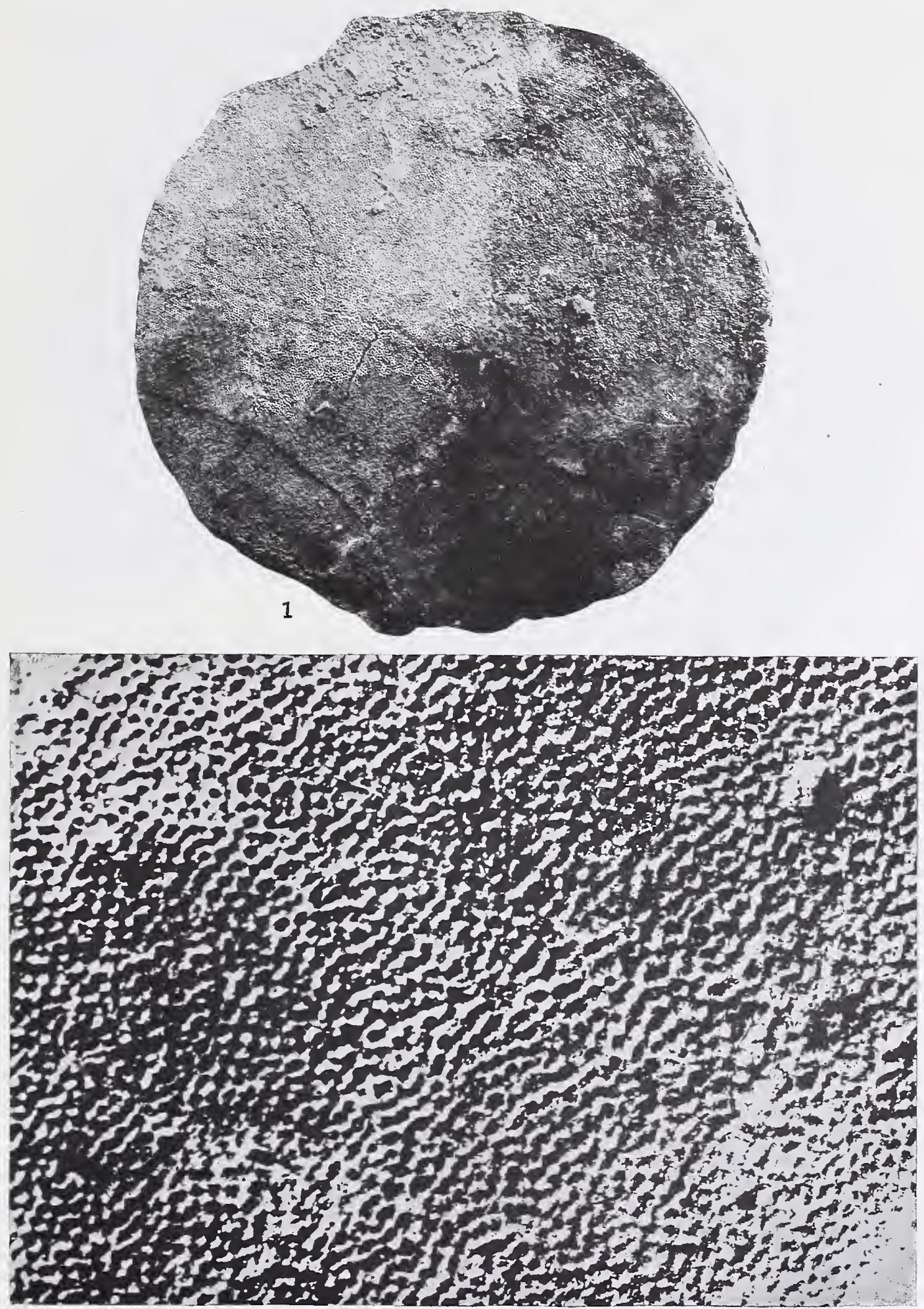

2

AMERICAN SPECIES OF LEPIDOCYCLINA. 

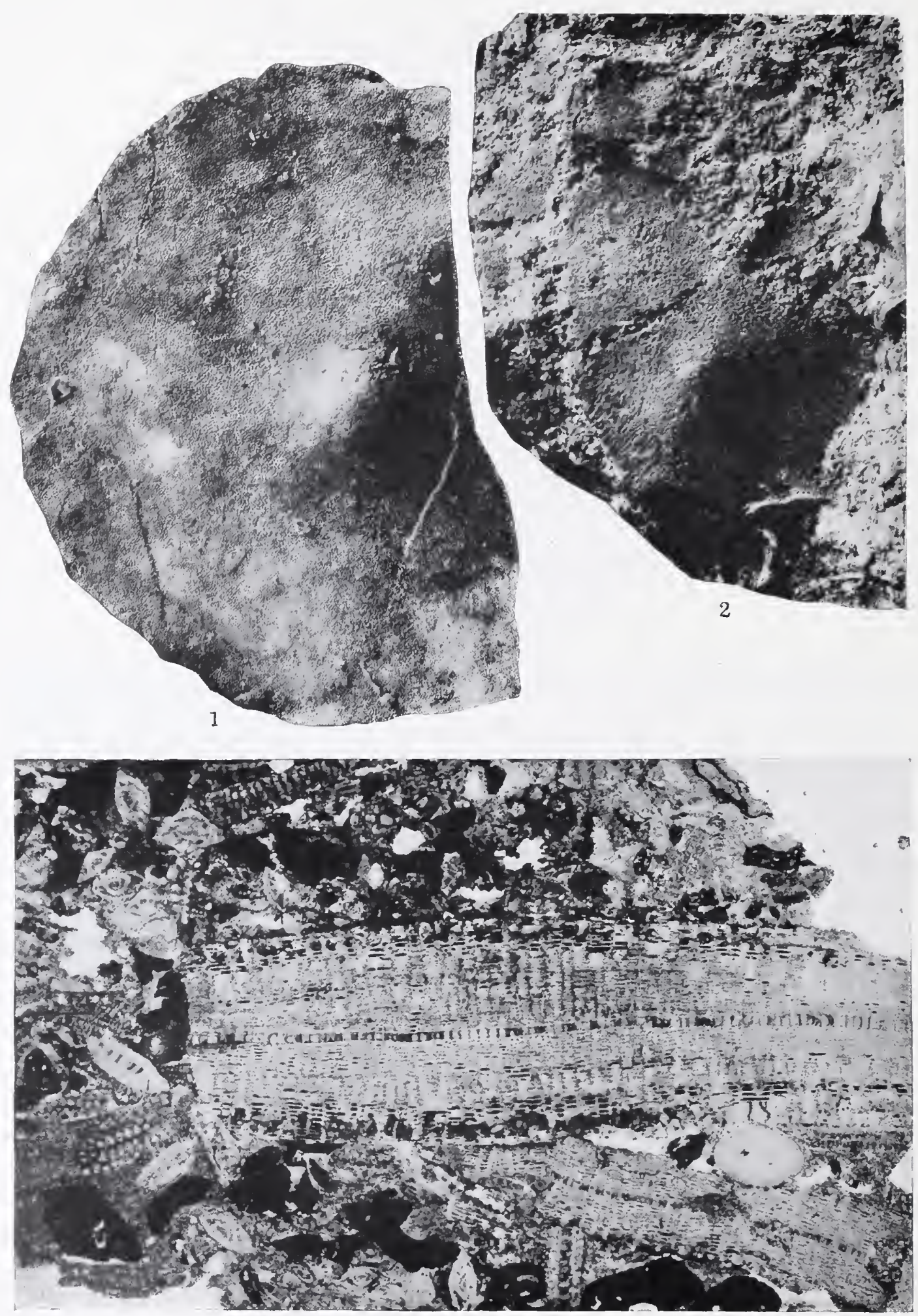

3

AMERICAN SPECIES OF LEPIDOCYCLINA. 


\section{PLATE XXI.}

Lepidocyclina gigas var. mexicana Cushman, n. var. (p. 63).

Figure 1. Surface view, $\times 2$. Meson formation, Meson, Vera Cruz, Mexico.

Figure 2. Surface view, $\times 2$. San Rafael formation, Topila Hills, near Tampico, Mexico.

Figure 3. Vertical sections, $\times 10$. San Rafael formation, Cerro Cortado, Topila Hills, Mexico. 


\section{PLATE XXII.}

\section{Lepidocyclina fragilis Cushman, n. sp. (p. 63).}

Figure 1. Suriace view, $X \bar{i}$. Ocala limestone at mouth of cavern, 200 yards southwest of wagon bridge over (hipola River east of Marianna, Fla. (U. S. G. S. station 7195).

Figtre 2. Surface view of portion of specimen, $\times 10$. (Kala limestone, left bank of Suwannee River above bridge of Florila Railway, suwannee ('ounty, Fla. (I. S. (x. S. station 7337).

\section{Lepidocyclina chaperi lemoine and R. Douvillé (p. 64).}

Flgere 3. Surface view, $\times 5$. Upper part of culebra formation, Panama Railroad, southern switch, Bohio Ridge, Panama (U.S. G. S. station 6025).

Figtre t. Portion of horizontal section, showing early chambers of the microspleric form, $\times 20$. West side of Gaillard Cut near Las Cascalas, Panama (U. S. G. S. station 6019f).

\section{Lepidocyclina vaughani Cushman (p. 64).}

Fictre 5. Specimen showing equatorial chambers and umbo, $\times 10$. Emperarlor limestone in cuttings of the Panama Railroarl near Caimito Junction, Panama (U. S. G. S. station 6021). 

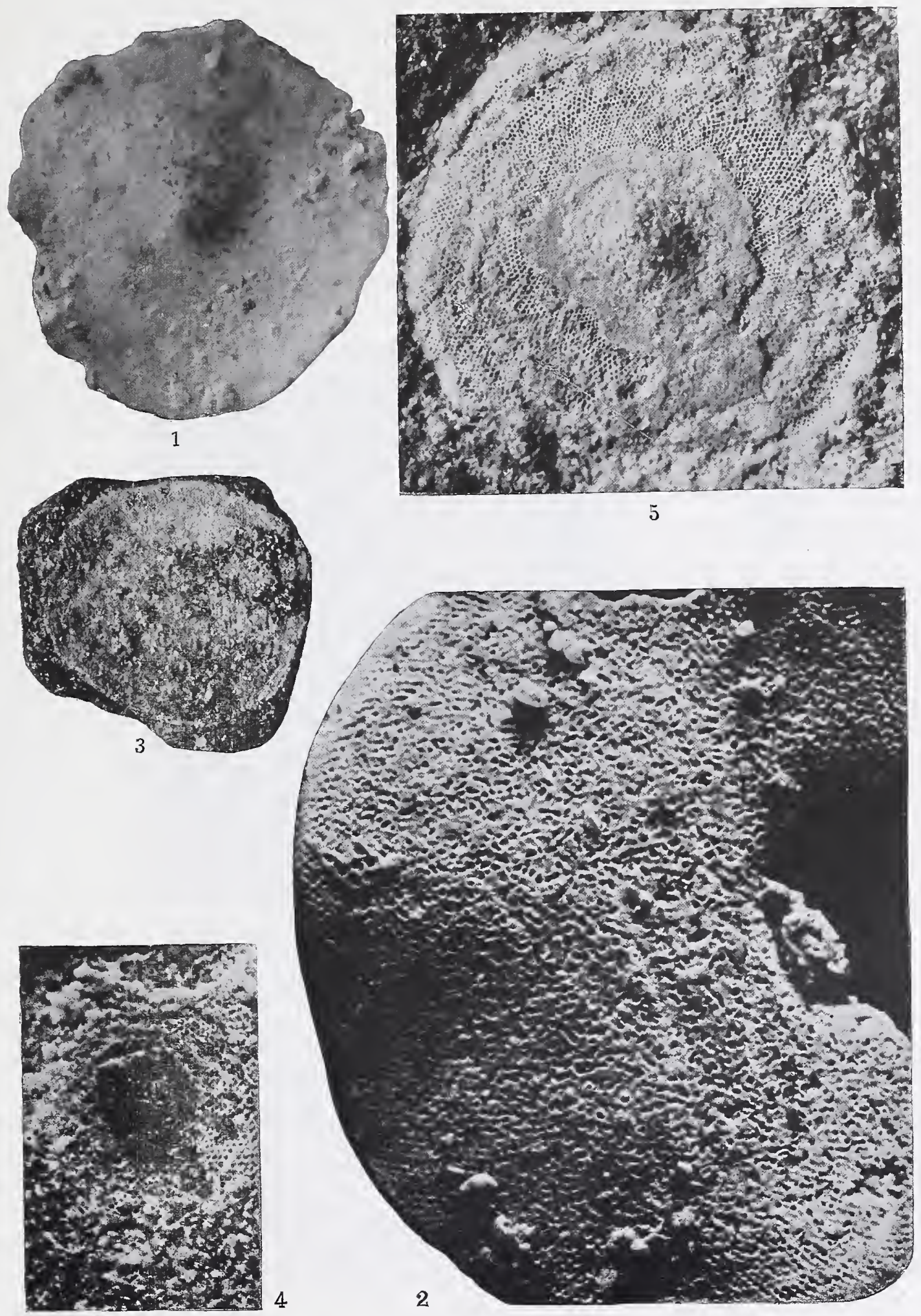

AMERICAN SPECIES OF LEPIDOCYCLINA. 

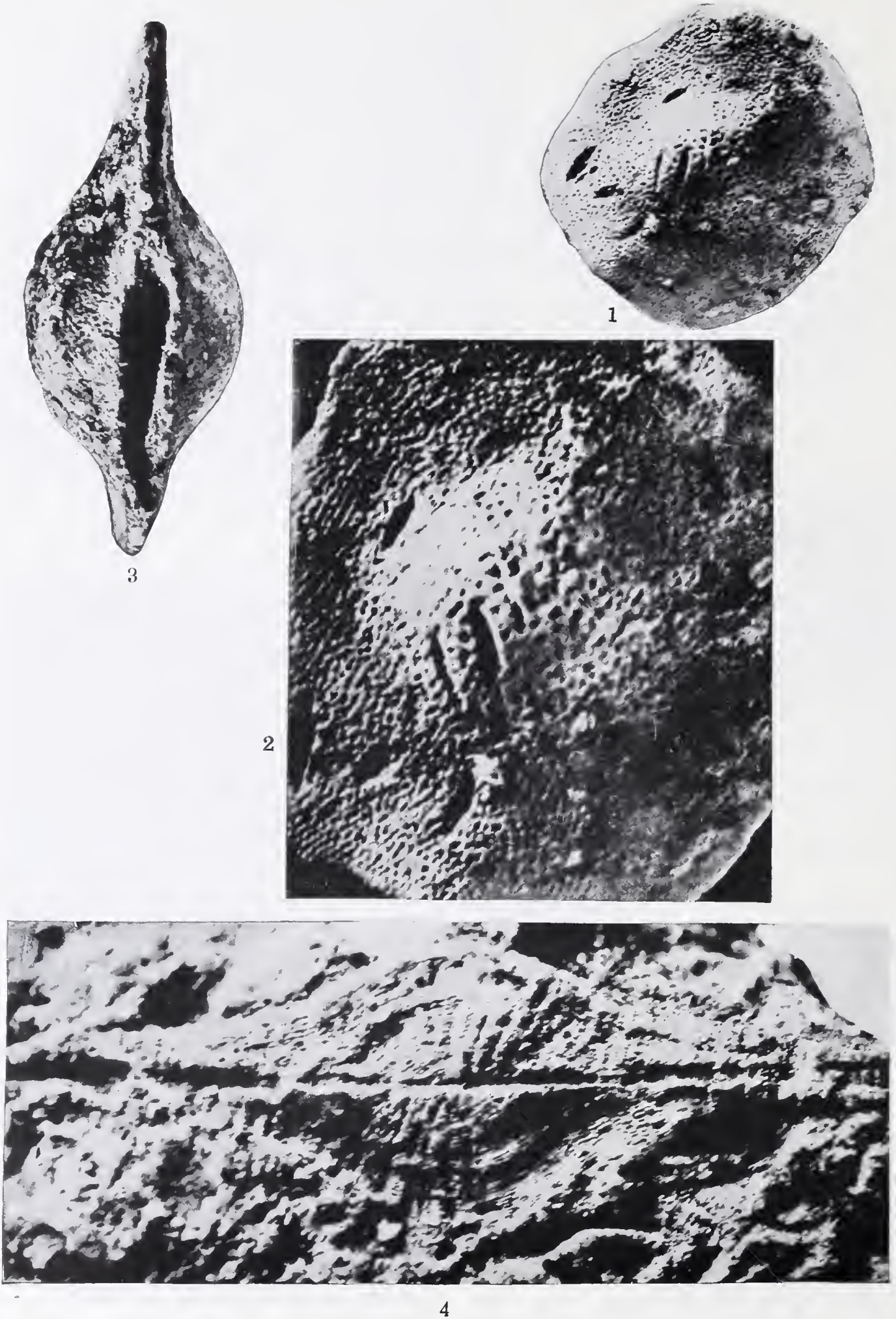

AMERICAN SPECIES OF LEPIDOCYCLINA. 


\section{PLATE XXIII.}

\section{Lepidocyclina chattahoocheënsis Cushman, n. sp. (p. 65).}

Figure 1. Surface view, $\times 5$. Five miles south of Jackson, Ala. (U. S. G. S. station 3647).

Figure 2. Surface view of central portion of same specimen, showing the pitted umbonal region, $\times 10$.

FIgUre 3 . Edge view of weathered specimen, $\times 5$. Old factory about $1 \frac{1}{2}$ miles above Bainbridge, Ga. (U. S. G. S. station 3397).

FigURE 4. Vertical section of weathered specimen, $\times 10$. Chattahoochee formation at Cato Glenn's well, $4 \frac{3}{1}$ miles southeast of Bainbridge, Ga. 


\section{PLATE XXIV.}

Lepidocyclina chattahoocheënsis Cushman, n. sp. (p. 65).

Figure 1. Surface view, $\times 5$. ('hattahoochee formation, Red Bluff on Flint River, 7 miles above Rainbridge, Ga. upper fossiliferous horizon (U. A.. (r. S. station 3388).

Flíure 2. Central portion of same specimen, $\times 10$.

Lepidocyclina pseudocarinata Cushman, n. sp. (p. 66).

Figure 3. Surface view, $\times 5$. Ocala limestone, left lyank of Suwannee River at Branford, Suwannee County, Fla. (U. S. G. S. station 7341).

Figure 4. Surface view of type specimen, $X 5$. Ocala limestone, Cummer lumber co.'s phosphate plant No. 6, $1 \frac{1}{4}$ miles south of Newberry, Fla. (U. S. G. S. station 6812).

Lepidocyclina cookei Cushman, n. sp. (p. 66).

Figure 5. Surface view of type specimen, $\times 5$. Ocala limestone (U. S. G. S. station 6812).

Figure 6. Central portion of same sperimen, $\times 10$.

Lepidocyclina attenuata Cushman, n. sp. (p. 67).

Figure 7. Surface view, $\times 2$. Ocala limestone, Richards quarry, Ocala, Fla.

Figure 8. Surface view of type specimen, $X 5$. Ocala limestone, quarry of Franklin Phosphate Co., $1 \frac{1}{2}$ miles northwest of Newberry, Alachua County, Fla. (U. S. G. S. station 6814).

94 

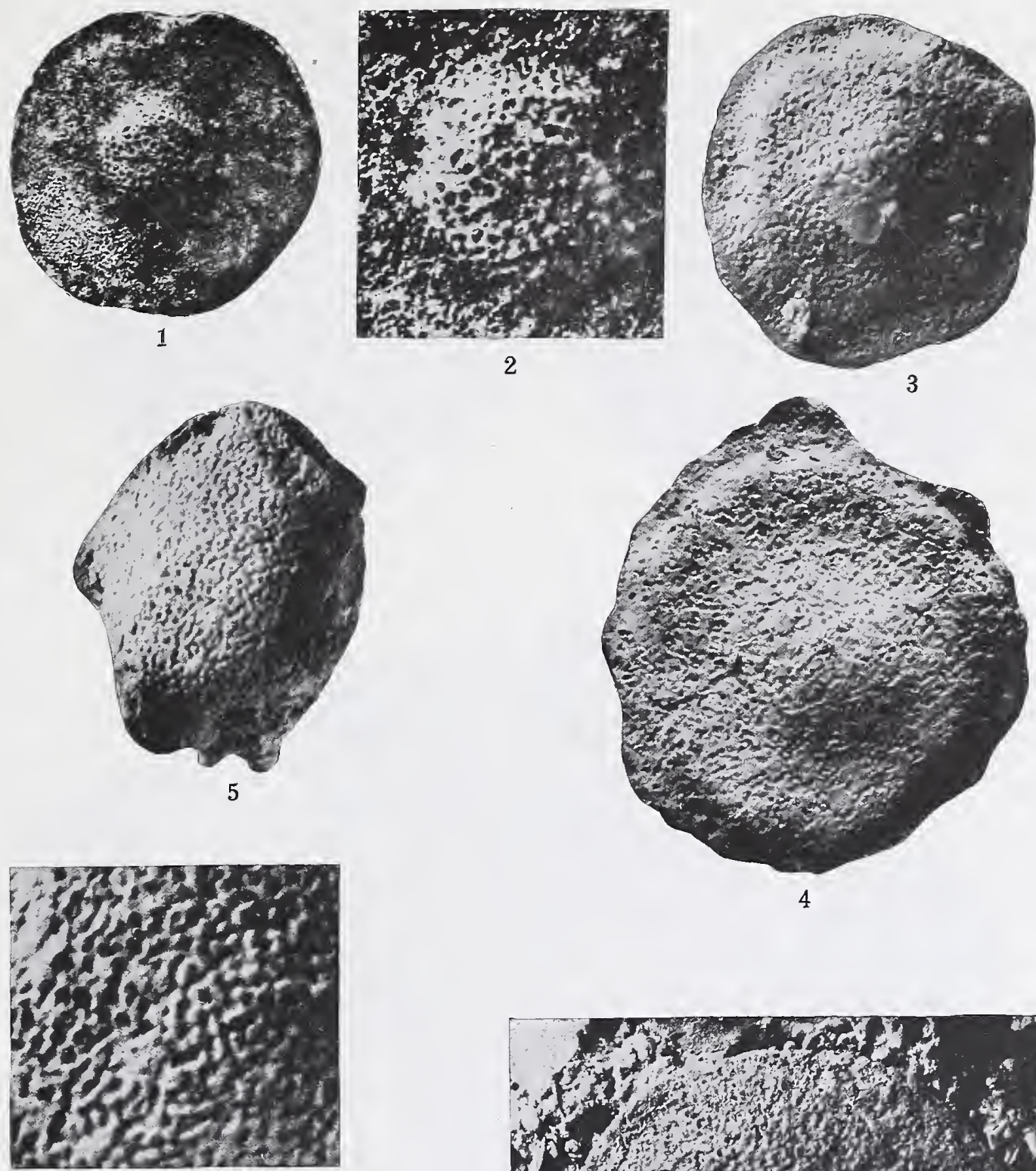

6
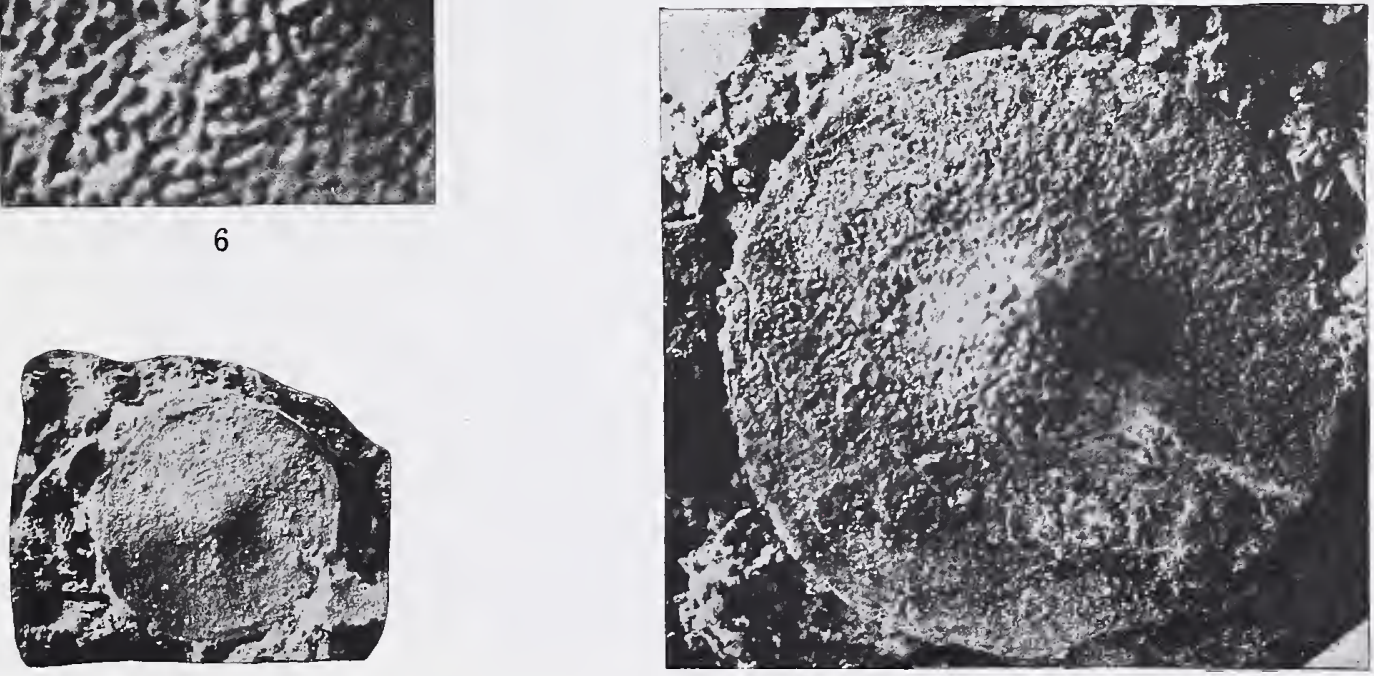

7

8

AMERICAN SPECIES OF LEPIDOCYCLINA. 

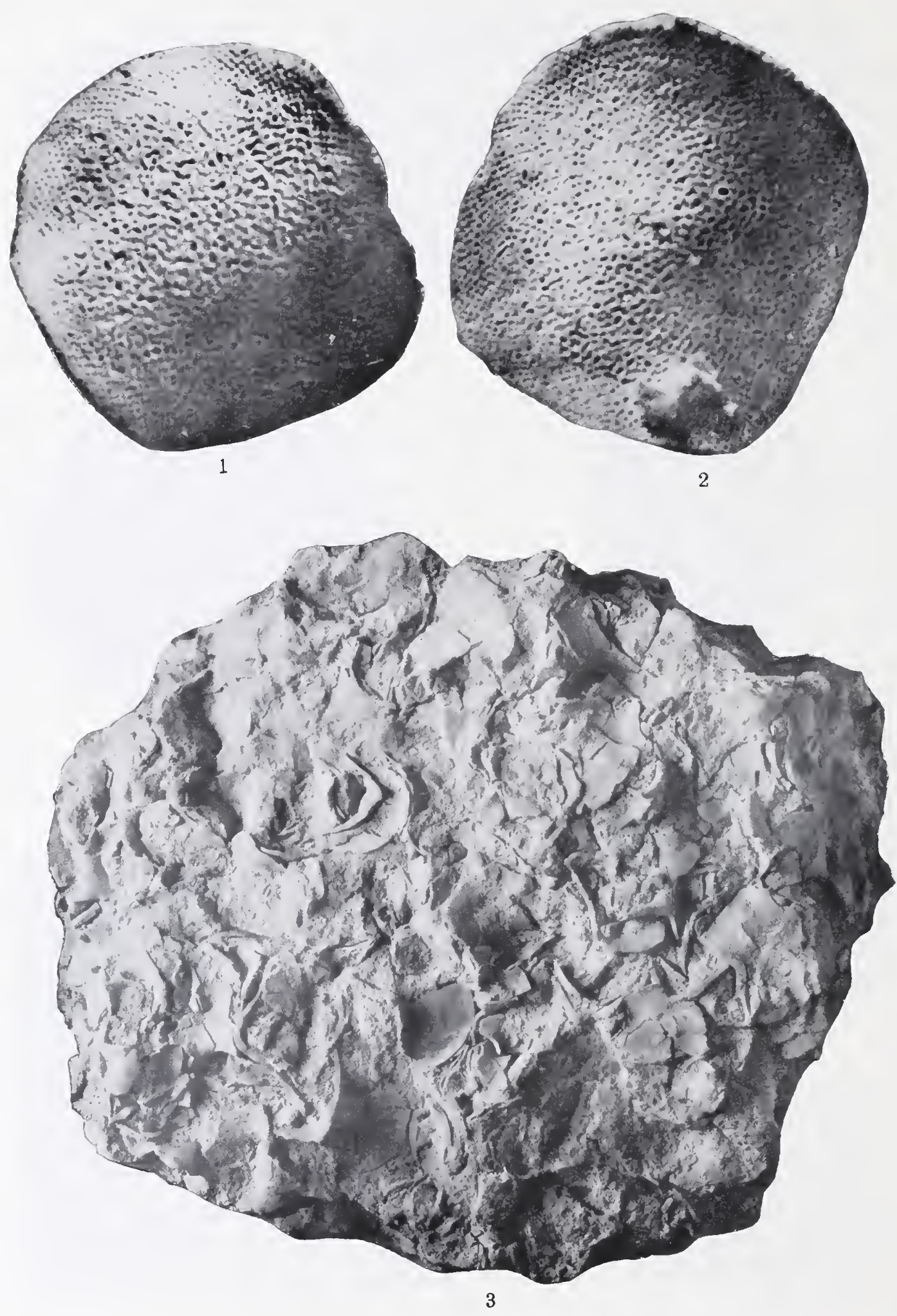

AMERICAN SPECIES OF LEPIDOCYCLINA. 


\section{PLATE XXV.}

Lepidocyclina floridana Cushman, n. sp. (p. 67).

Figure 1. Surface view of type specimen, $\times 10$, showing reticulate surface without pillars and strong saddle shape. Ocala limestone, quarry one-eighth mile southeast of Martins Station, 9 miles north of Ocala, Fla. (U. S. G. S. station 6808).

Figure 2. Surface view of similar specimen, $\times 10$, from same locality.

Lepidocyclina undosa Cushman (p. 68).

Figure 3. Rock specimen largely composed of Lepidocyclina undosa, from Long Island, Antigua, Leeward Islands (U. S. G. S. station 6869). 


\section{PLATE XXTT.}

\section{Lepidocyclina perundosa Cushman (p. 68).}

Figure 1. Section through the emlryonic chamber and portions of two sides of the saddle-shaped test, $\times 10$. Nuevitas, Cuba (U.S. G. S. station 3478).

\section{Lepidocyclina pseudomarginata Cushman, n. sp. (p. 69).}

Figure 2. Surface view of young specimen with the peripheral portion not greatly developed, $\times 5$. Ocala limestone, Suwaniee River at Dowling Springs, Suwannee County, Fla. (U. S. G. S. station 7338).

Figure 3. Surface view of type specimen, $\times 5$. Ocala limestone, Archer, Fla. (U. S. G. S. station 3683 ).

FIgURE 4. Central portion of same specimen, $\times 10$.

Lepidocyclina supera (Conrad) H. Douvillê (p. 69).

Figure 5. Surface view, $\times 2$. Byram marl, bluff just above the second sawmill on the river, horizon No. 2 from the top, Vicksburg, Miss. (U. S. G. S. station 3722).

Fifures 6, 7. Aherrant specimens, $\times 2$. Byram calcareous marl, west bank of Pearl River, Byram, Iinds Comty, Miss (U. S. G. S. station 5623). 


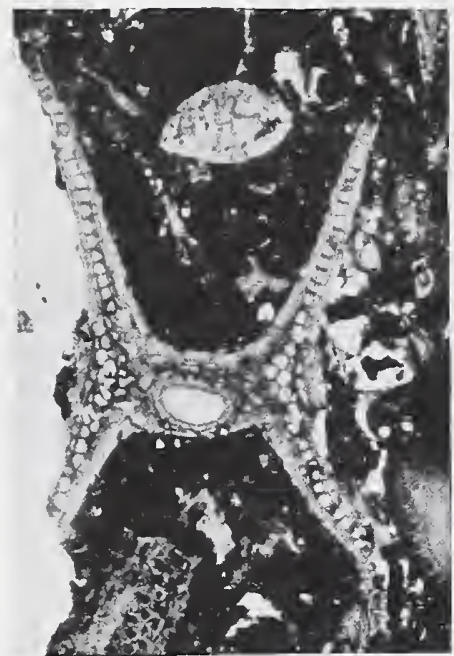

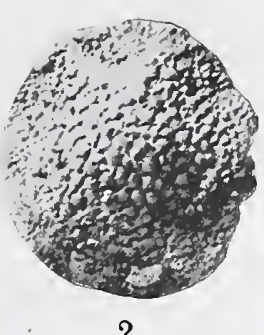

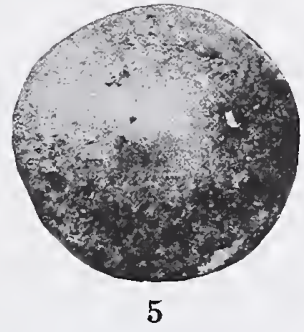

6
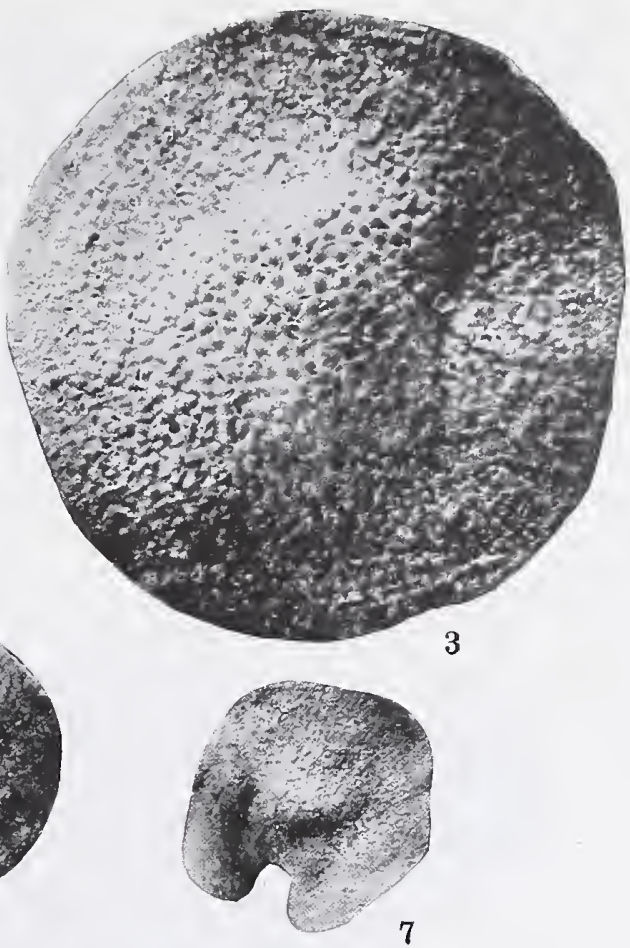

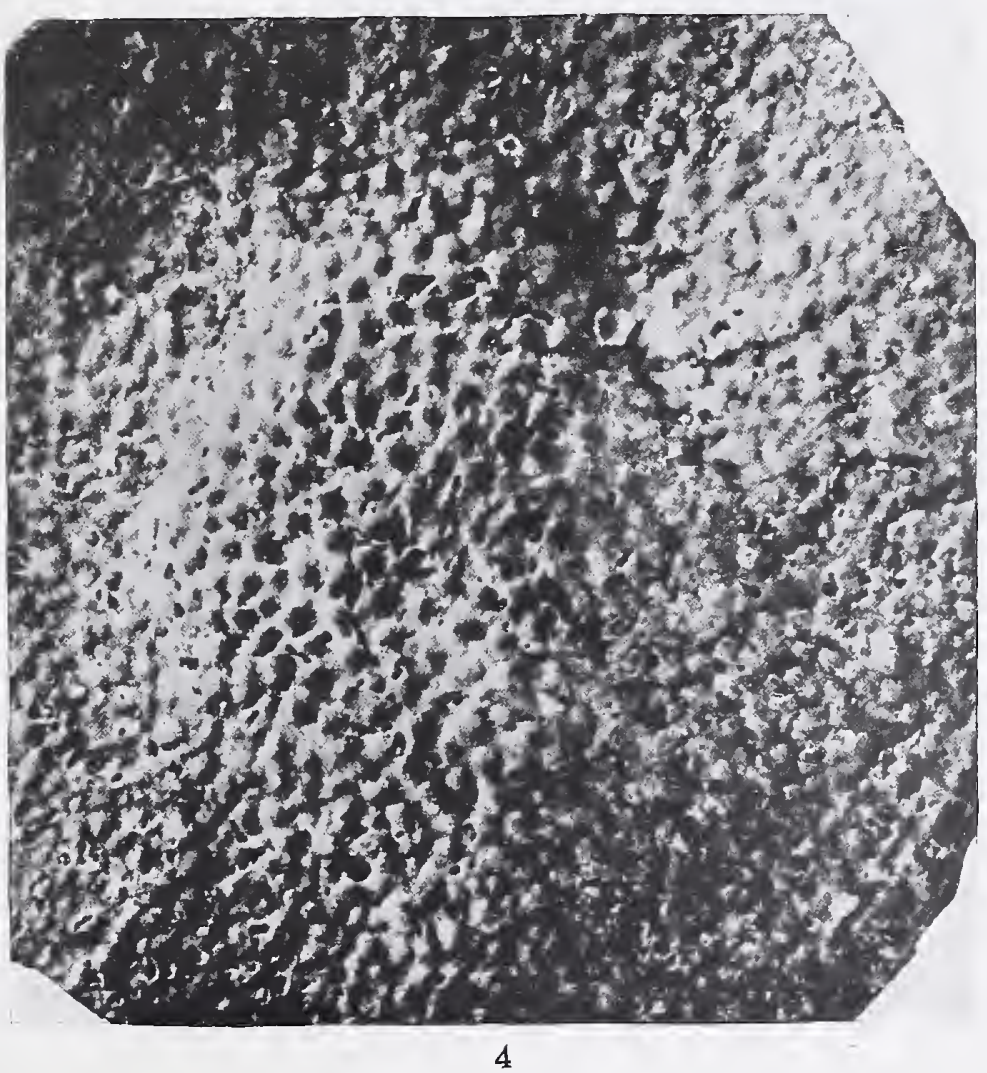

AMERICAN SPECIES OF LEPIDOCYCLINA. 


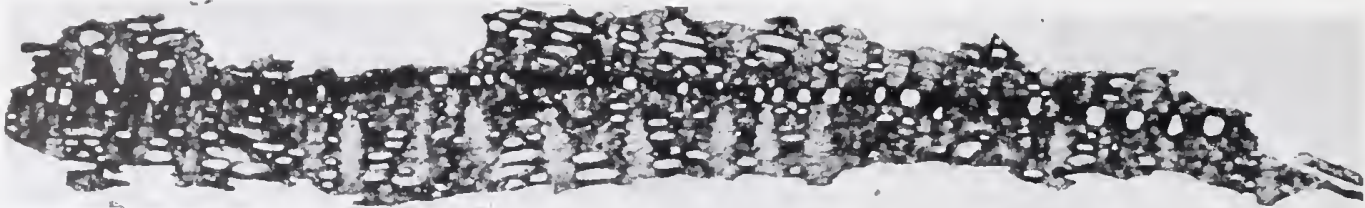

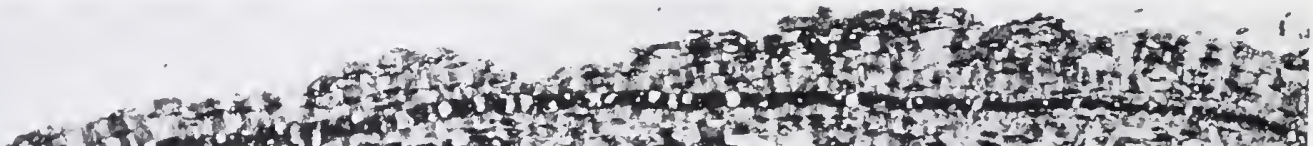

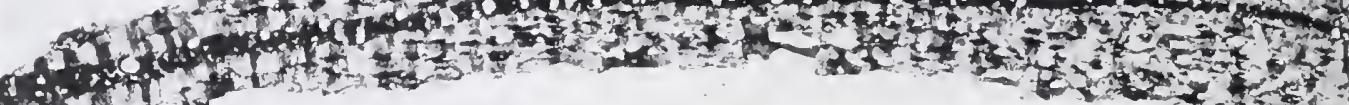

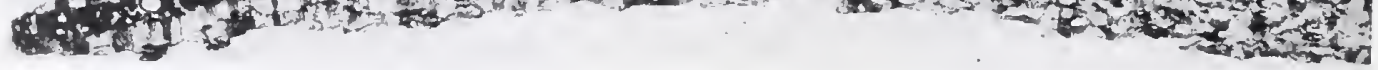

2
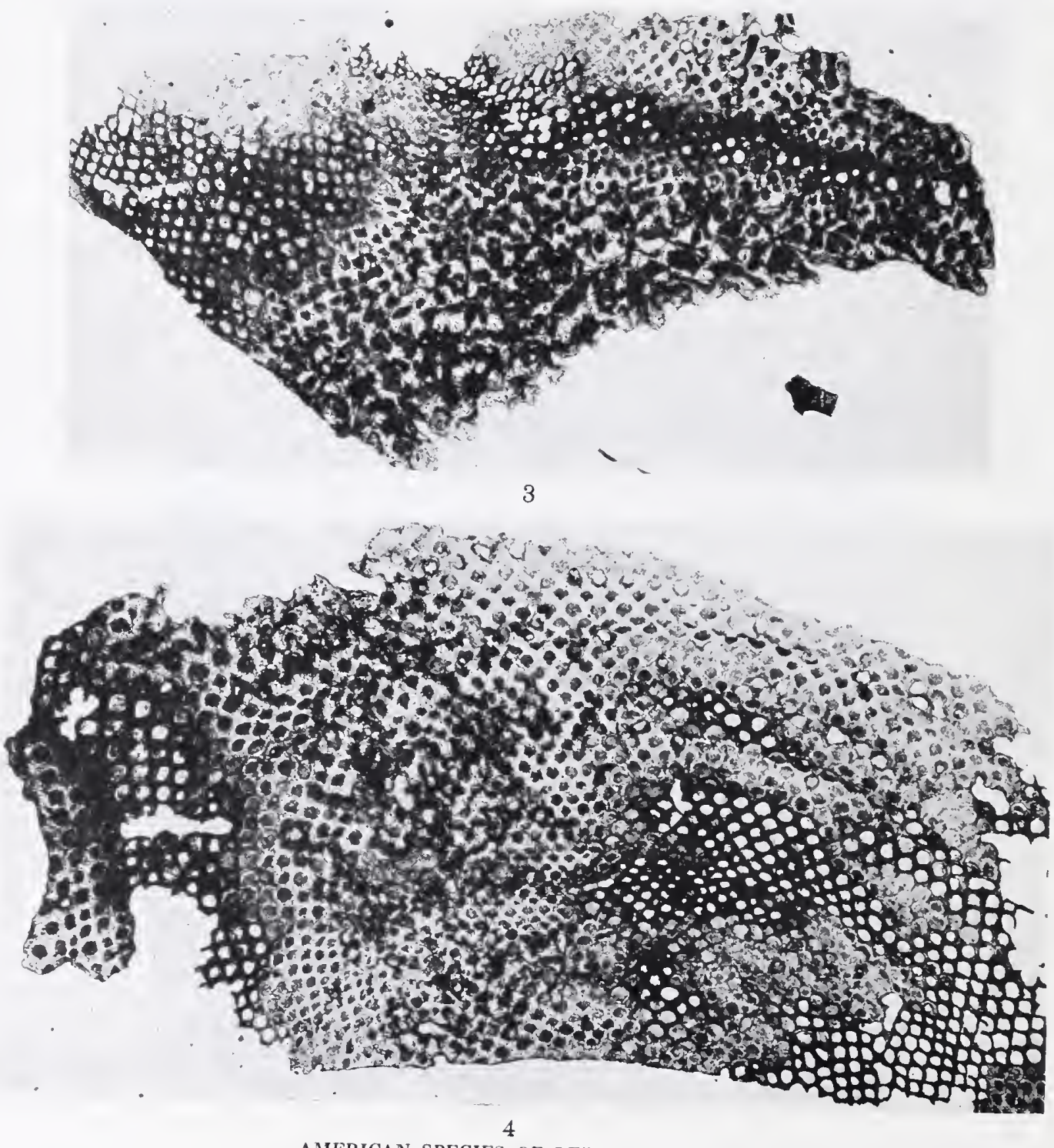

AMERICAN SPECIES OF LEPIDOCYCLINA 


\section{PLATE XXVII.}

Lepidocyclina mortoni Cushman, n. sp. (p. 70).

Figure 1. Vertical section, $\times 20$, showing the numerous large, wedge-shaped pillars.

Figure 2. Vertical section, $\times 15$, showing the very heavy walls and the comparatively small chamber spaces.

FigurE 3 . Oblique section, $\times 20$, showing the relative arrangement of pillars and chambers.

Figure 4. Horizontal section, $\times 20$, showing the equatorial chambers.

All specimens from bluff at Montgomery, Grant Parish, La. (U. S. G. S. station 4270). $131049^{\circ}-20-9$ 


\section{PLATE XXIIII.}

Lepidocyclina mortoni Cushman, n. sp. (p. 70).

Figure 1. Enlarged surface view, $\times 10$, showing the surface distribution of the ends of the pillars. Bluff at Montgomery, Grant Parish, La. (U. S. G. S. station 4270).

Figure 2. Surface view of same specimen, $\times 2$.

\section{Lepidocyclina ocalana Cushman, n. sp. (p. 71).}

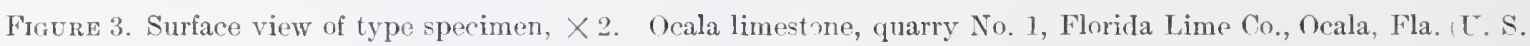
G. S. station 6504 ).

Figure 4. Portion of the surface of another specimen, $\times 10$. Johnson's lime sink, lery Comnty, Fla. (U. S. G. S. station 36.5$)$.

Lepidocyclina ocalana var. subdecorata Cushman, n, var. (p. 72 ).

Figure 5. Surface view of type specimea, $X 2$. Johnson's lime sink, Levy ('onnty, Fla. I L. S. G. S. station 365). 


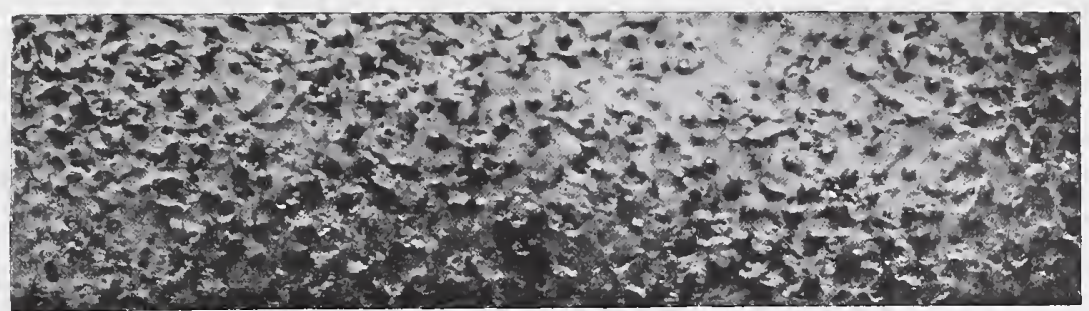

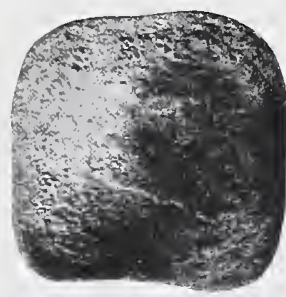

2
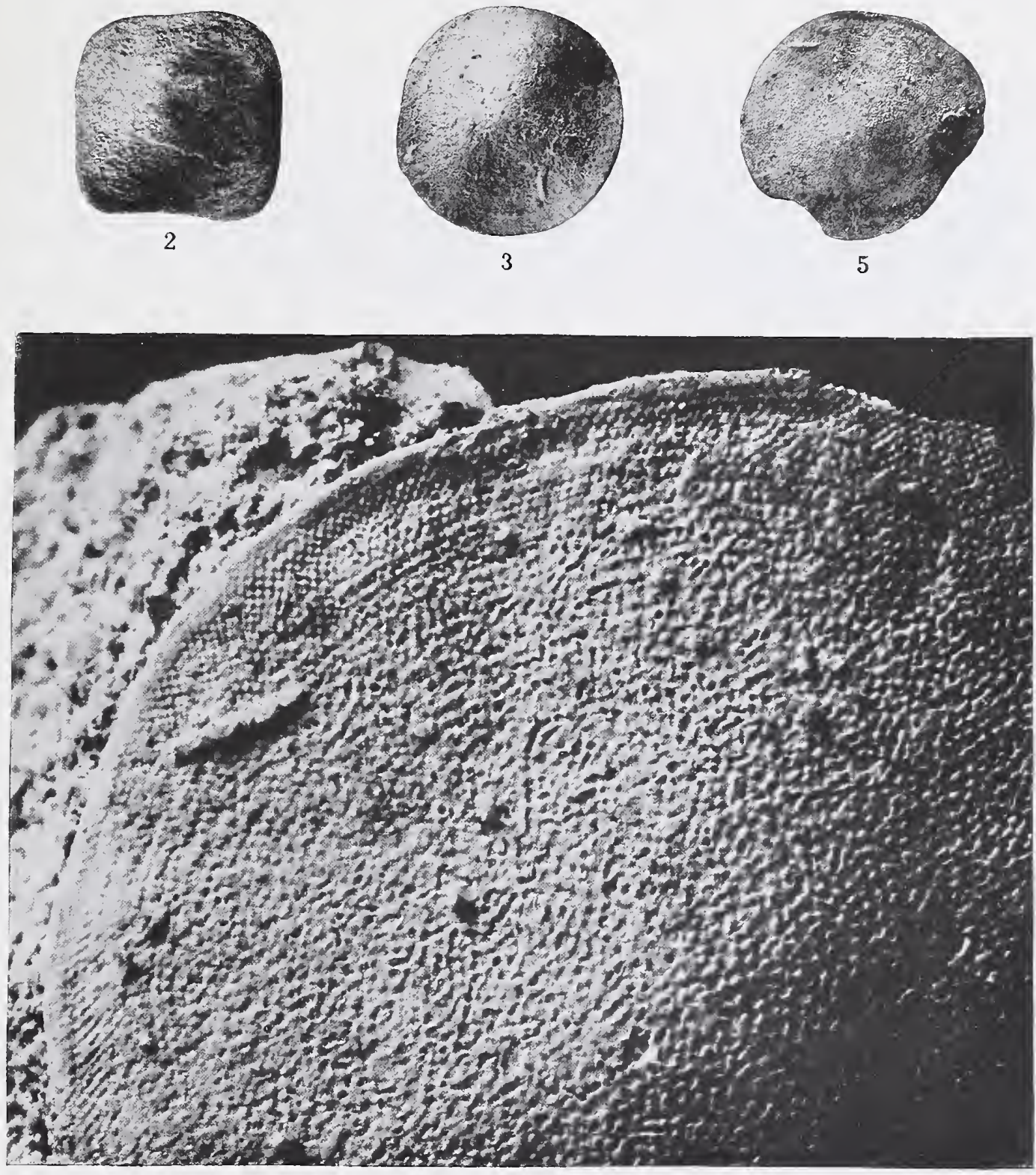

4

AMERICAN SPECIES OF LEPIDOCYCLINA 

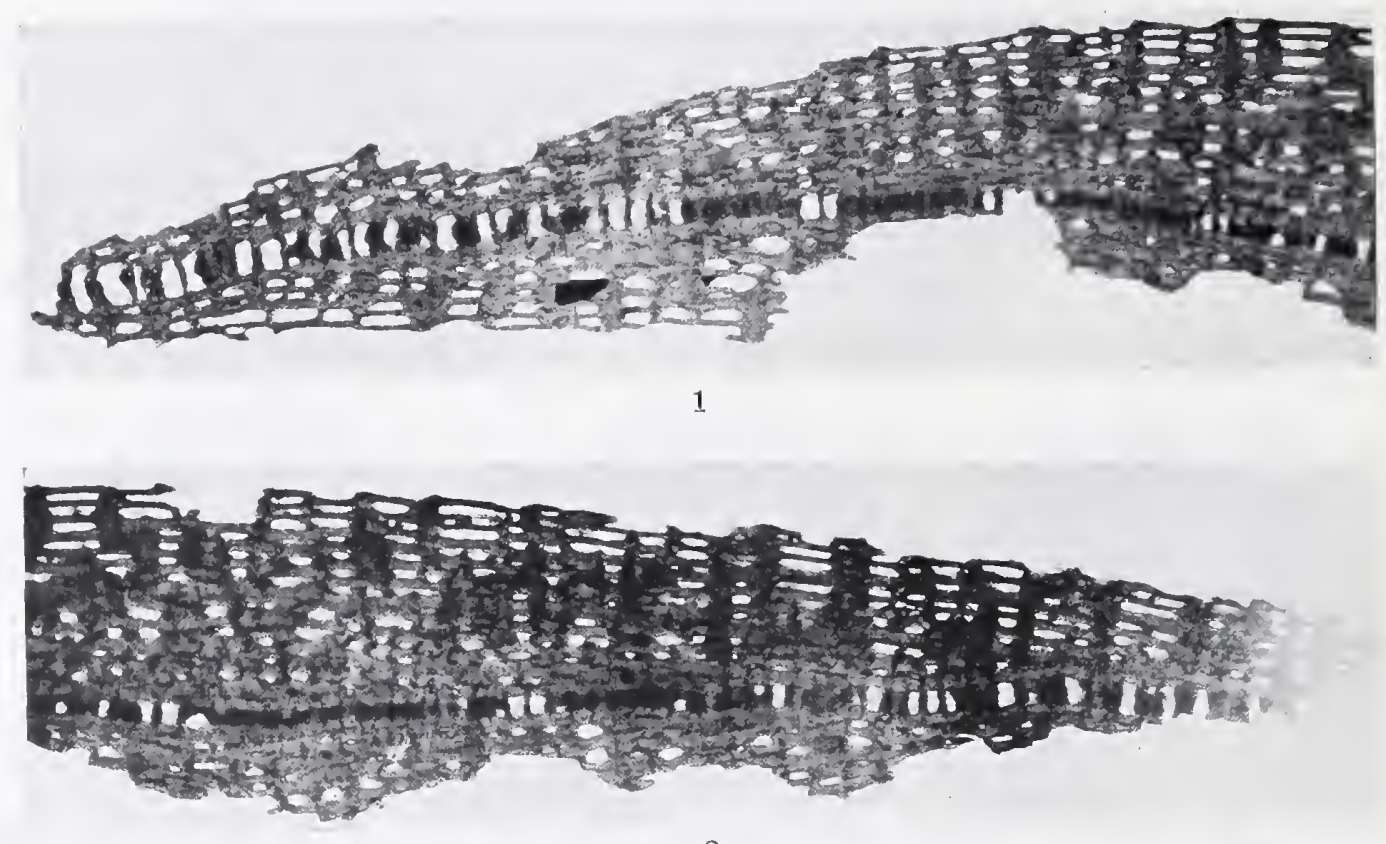

\section{2}

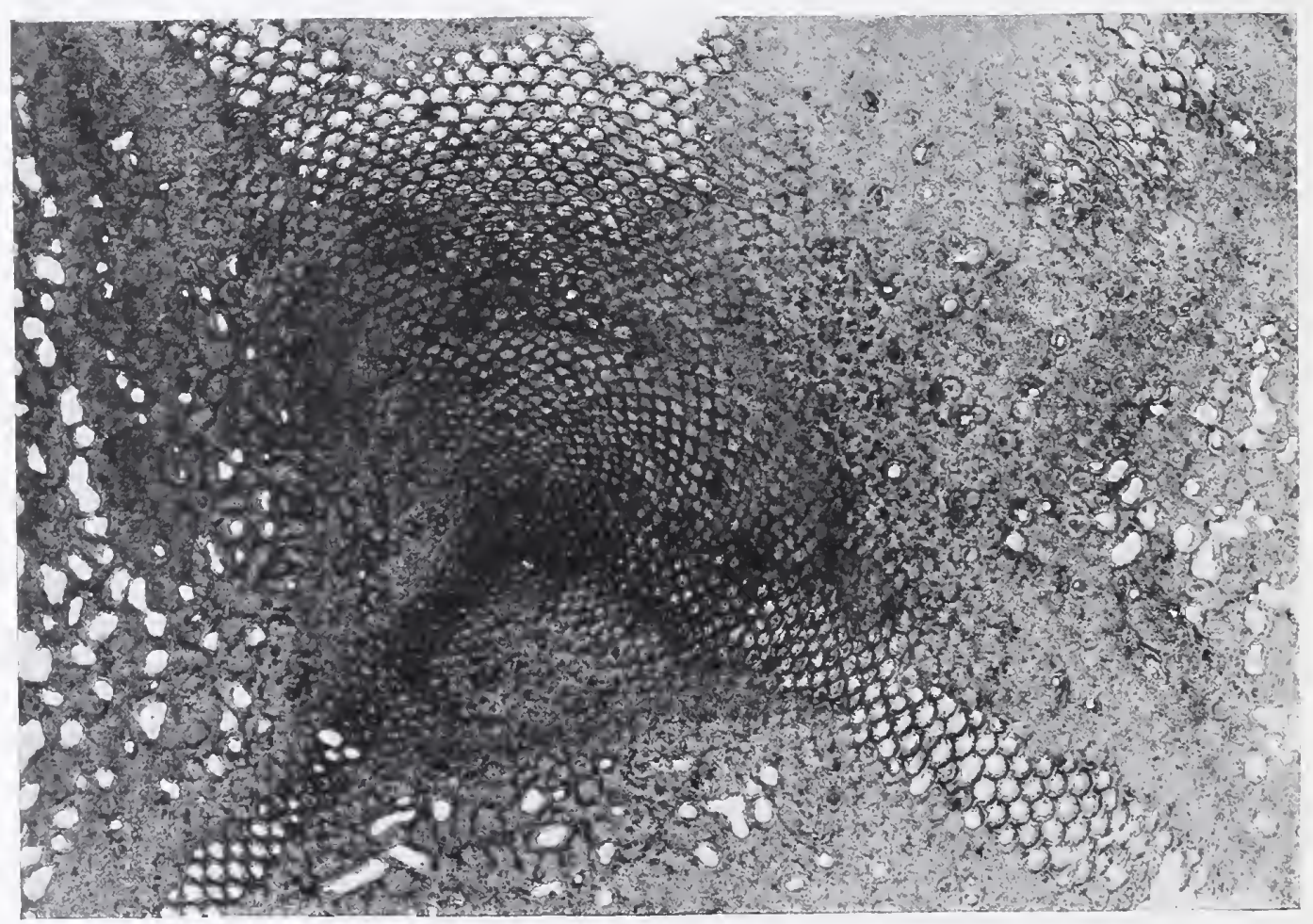




\section{PLATE XXIX}

\section{Lepidocyclina ocalana Cushman, n. sp. (p. 71).}

FIgure 1. Vertical section, $\times 20$. Ocala limestone, plant No. 3 , Florida Lime Co., $6 \frac{1}{2}$ miles north of Ocala, at Zuber post office, Marion County, Fla. (U. S. G. S. station 6807).

Figure 2. Opposite half of same section.

Figure 3. Horizontal section, $\times 20$, of microspheric form of the species from same locality. 


\section{PLATE XXX.}

\section{Lepidocyclina subraulinii Cushman (p. 73).}

Figure 1. Surface view of type specimen, $\times 5$. Nuevitas, Cuba (U. S. G. S. station 3478 ).

Figure 2. Slightly oblique section, showing a few of the equatorial chambers and the pillars and lateral chambers, $\times 20$ Limestone at Sierra Guaso, Cuba (U. S. G. S. station 7666).

Ftgure 3. Portion of vertical section, $\times 20$, showing equatorial and lateral chambers and the numerous pillars. Same locality as figure 2.

Figure 4. Portion of vertical section, $\times 15$. Meson formation, San Jose de las Rusias, Mexico.

Figure 5. Larger portion of same specimen, $\times 10$.

Figure 6. A few of the outer chambers in vertical section $\times 20$, showing the perforations in the peripheral wall of the equatorial chambers. Same locality as figure 4. 

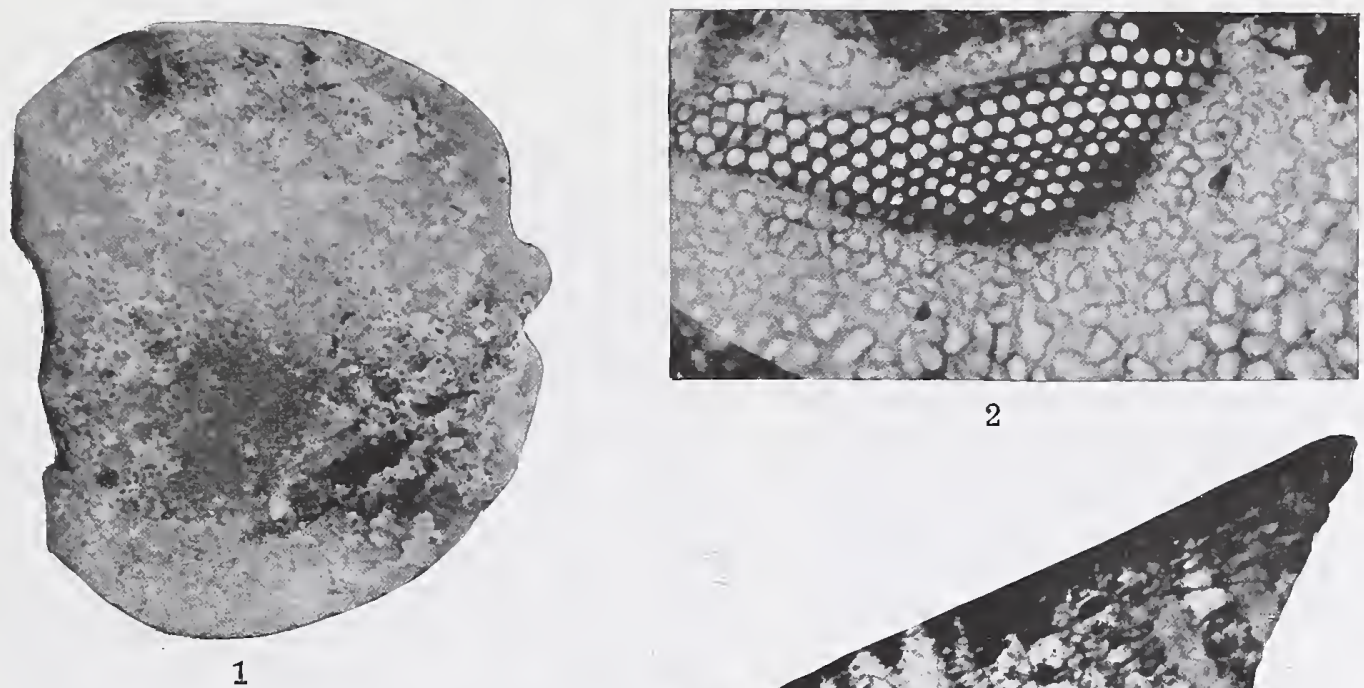

2

13

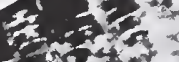

I.

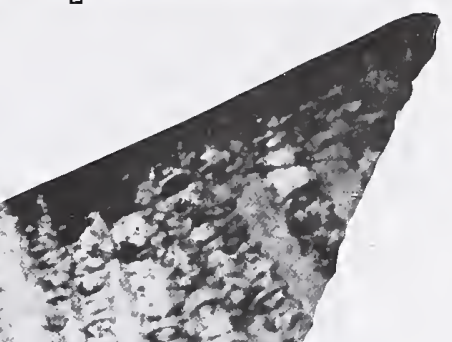

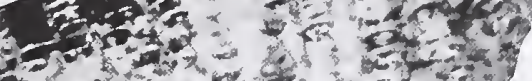

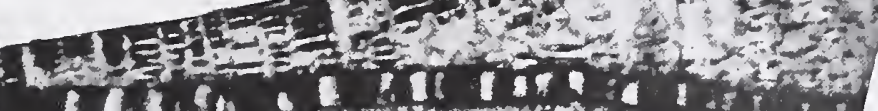

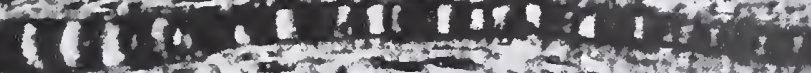

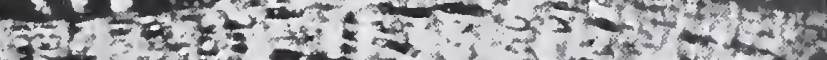

1ㄴ.

3

$t^{2}+x^{2}$

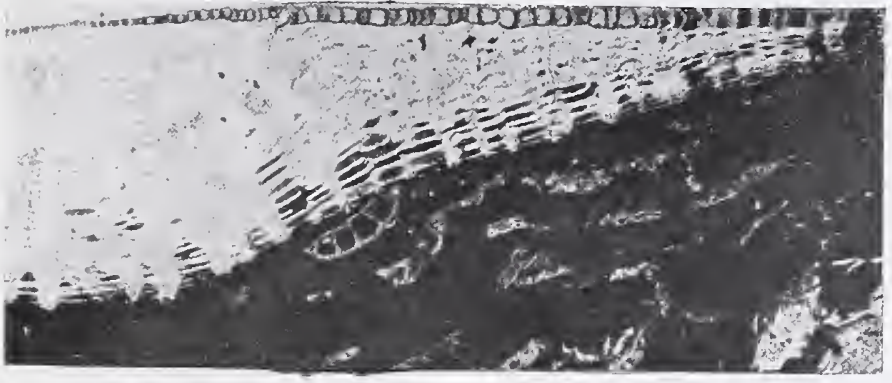

4

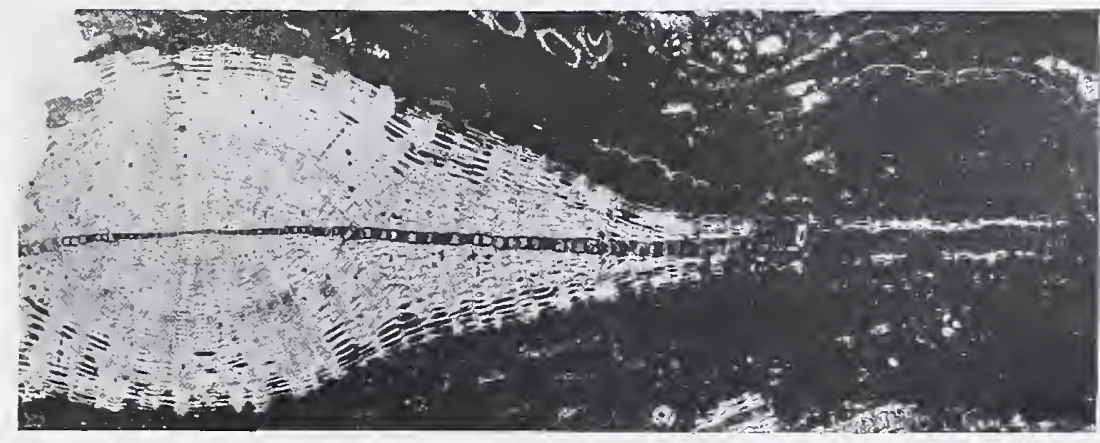

5

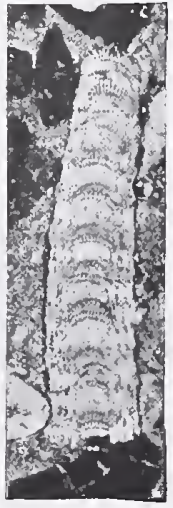

6

AMERICAN SPECIES OF LEPIDOCYCLINA. 

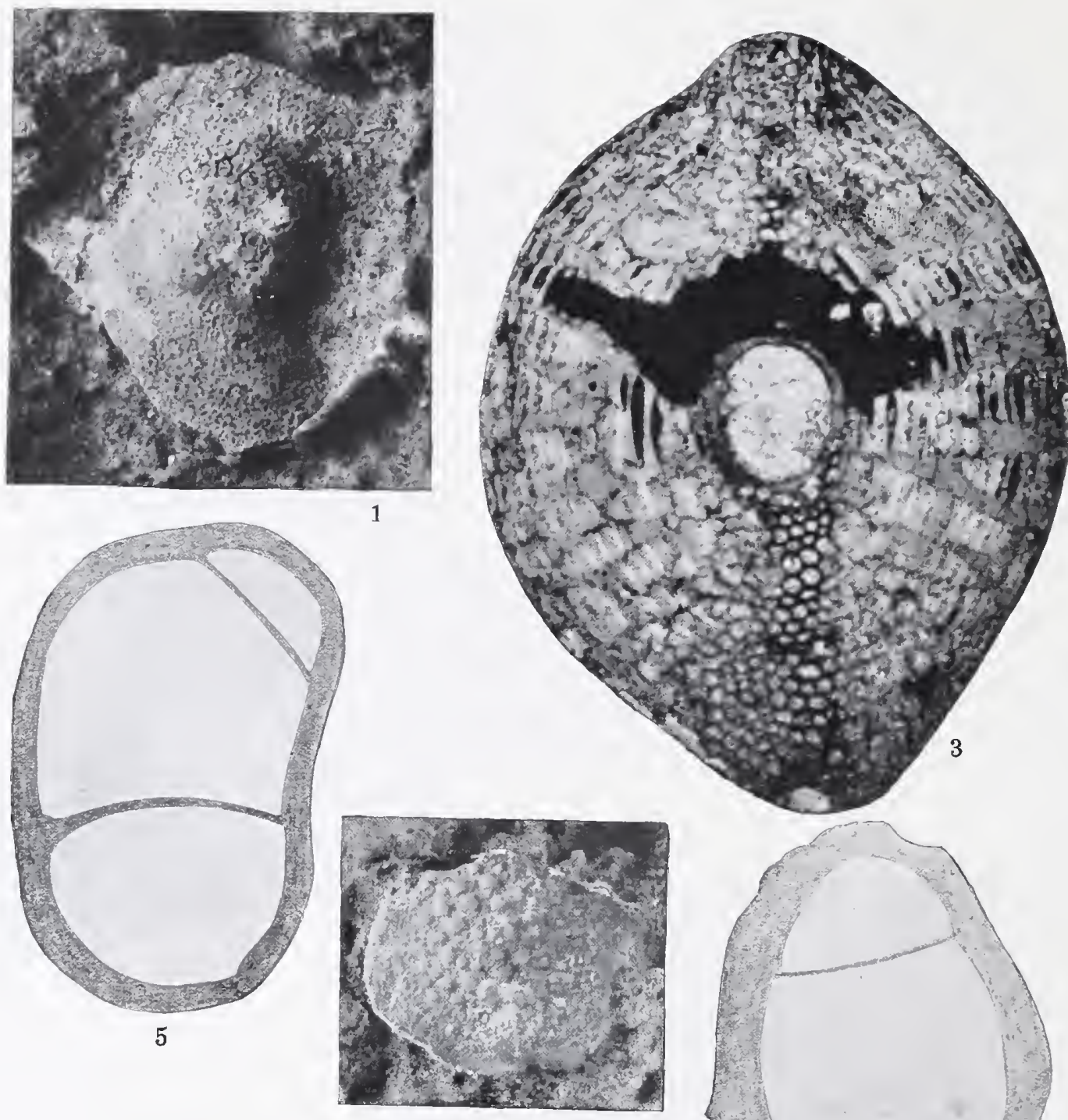

2

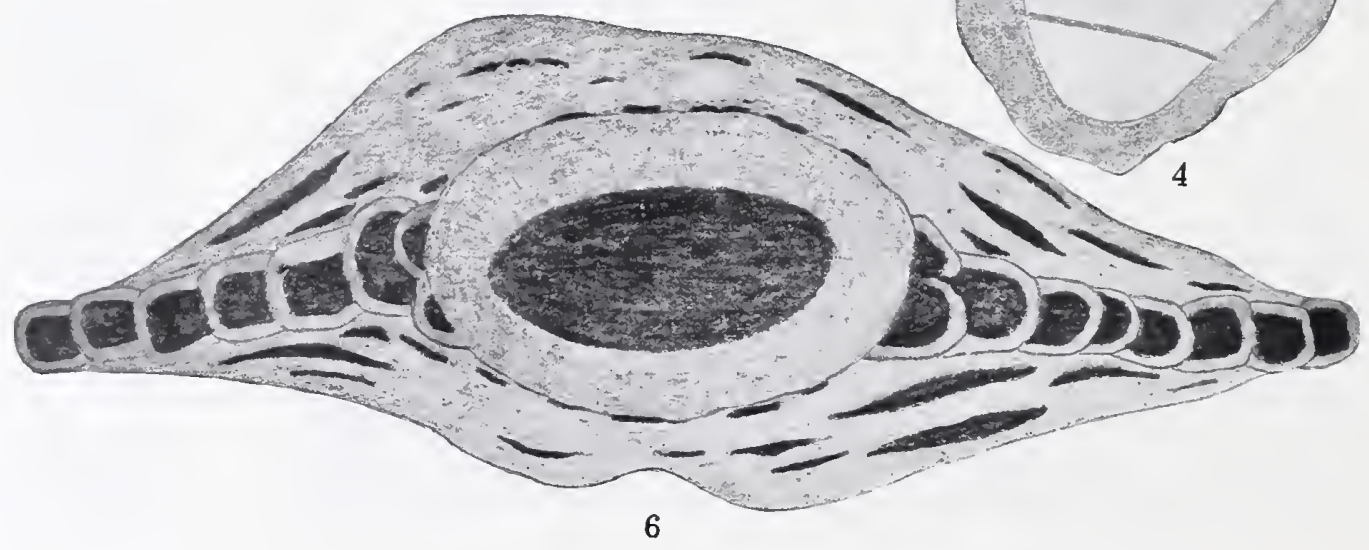

AMERICAN SPECIES OF LEPIDOCYCLINA. 


\section{PLATE XXXI.}

Lepidocyclina marginata (Michelotti) Lemoine and R. Douvillê (p. 73).

Figure 1. Surface view of specimen, $\times 5$. Limestone on south side of Los Melones Mountain, near west end, near Guantanamo, Cuba (U. S. G. S. station 7518).

Figure 2. Surface view of smaller specimen, $\times 5$, from same locality.

\section{Lepidocyclina crassata Cushman (p. 74).}

Figure 3. Oblique section, $\times 20$. Orbitoidal limestone outcrop where Palmer trail joins Ocujal trail, near Guantanamo, Cuba (U. S. G. S. station 7513).

Flgures 4, 5. Embryonic chambers, showing the thick wall and thinner ones of the subdivisions, $\times 60$. Sections of limestone from drift near top of landslide next north of Los Melones, Cuba (U. S. G. S. station 7519).

Figure 6. Vertical section of young specimen, $\times 40$, from same locality. 


\section{PLITE XXXII.}

\section{Lepidocyclina canellei Lemoine and R. Douvillé (p. 75).}

Figure 1. View of exterior, $\times 10$. liohio, Panama (U. S. N. M. catalogue No. 135216). a

Figure 2 . Horizontal section, $\times 20$, showing hexagonal equatorial chambers and irregularities in the annuli due to repairs by the animal of breakage in the test. West side of Gaillard Cut near Las Cascarlas, Panama (U. S. G. S. station 6019a).

Figures 3,4 . Vertical sections, in figure 3, through the embryonic chambers, shown in figure 4, at one side. Bohio, Panama.

Figure 5 . Slightly oblique section, $\times 20$, showing narrow zone of equatorial chambers and two broader zones of lateral chambers, the latter without pillars. Bohio, Panama.

Lepidocyclina canellei var. yurnagunensis Cushman (p. 76).

FIGURE 6. Slightly oblique section, $\times 20$, showing the embryonic chambers (Pliolepidina of Douvillé). Flexure 2 miles south of Yurnaguna, Cuba (U. S. G. S. station 7548).

Figure 7. Section of limestone, $\times 20$, showing abundance of specimens of this variety. Same localit $y$ as figure 6 . 

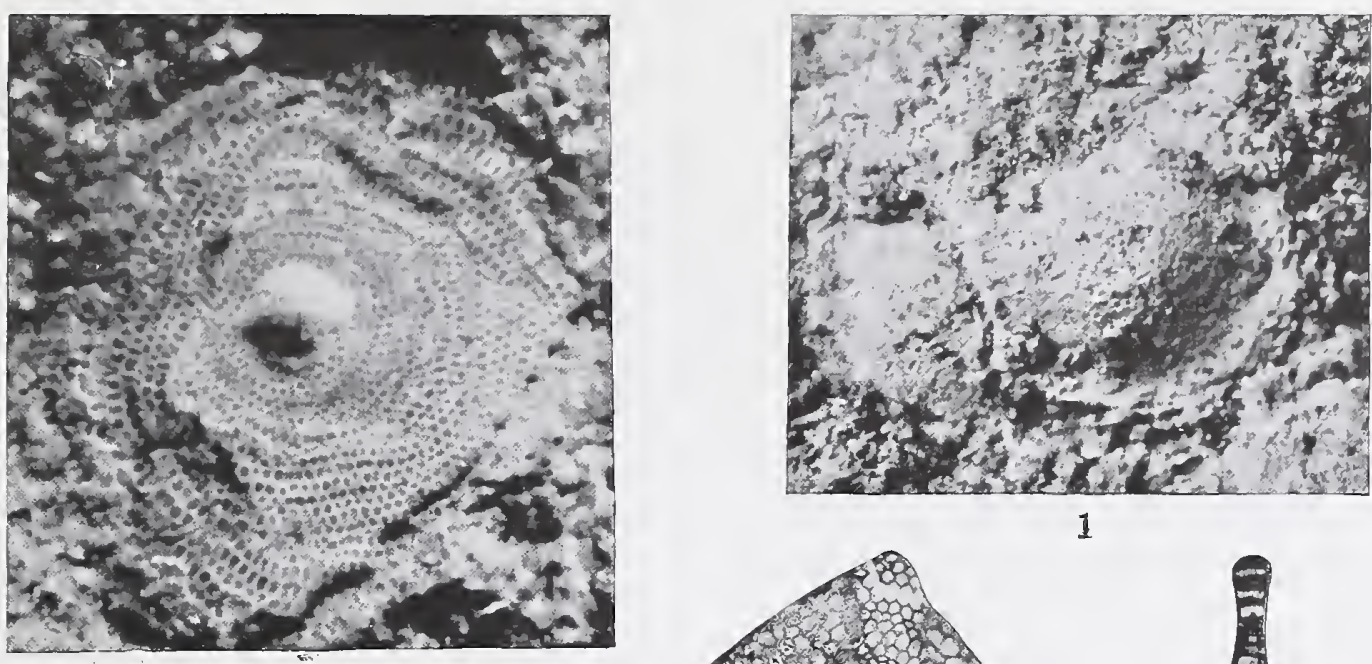

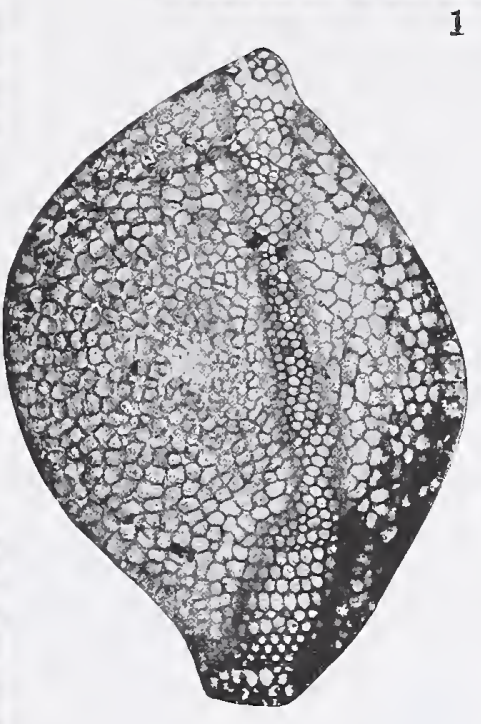

5
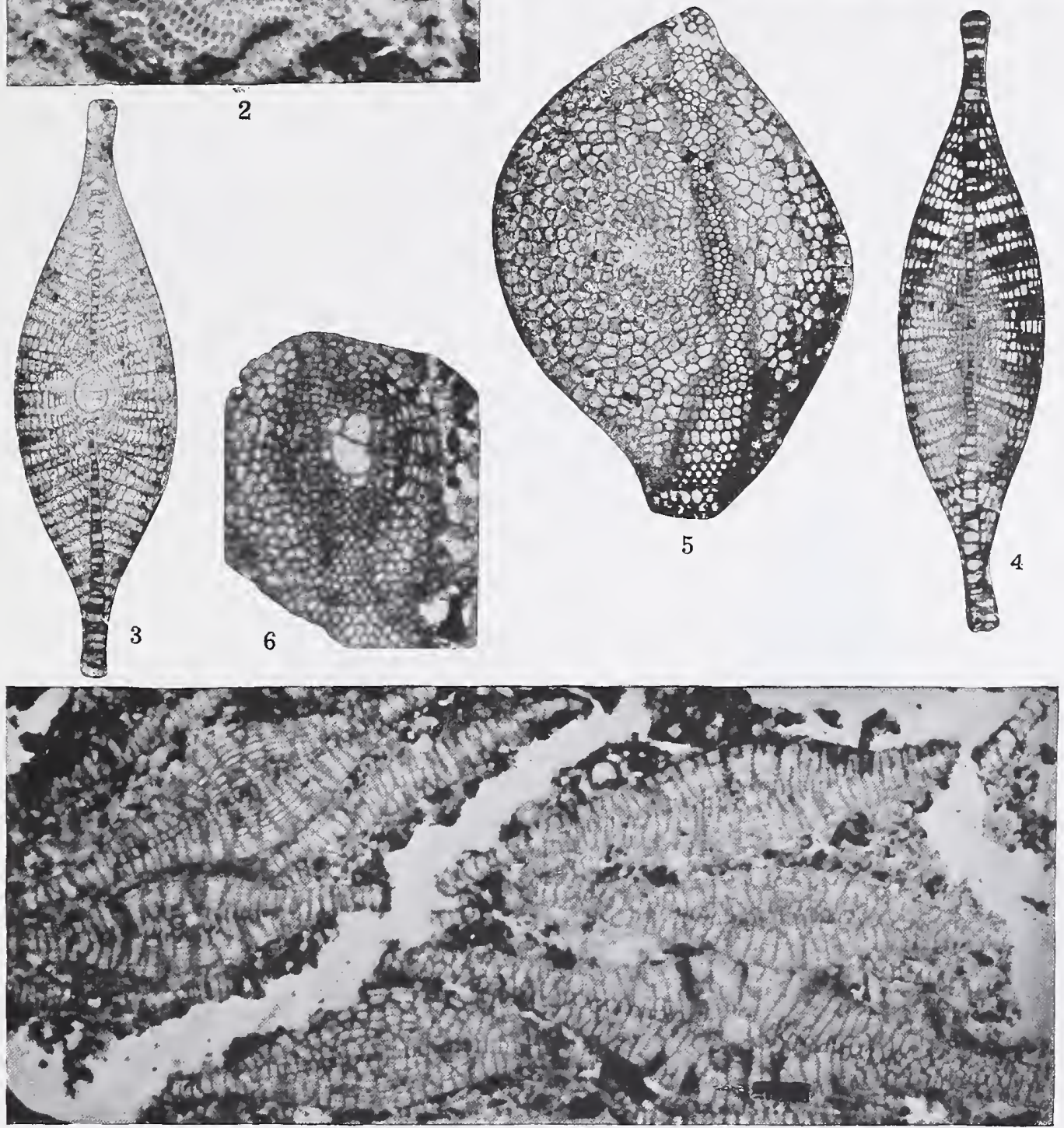

7

AMERICAN SPECIES OF LEPIDOCYGLINA. 

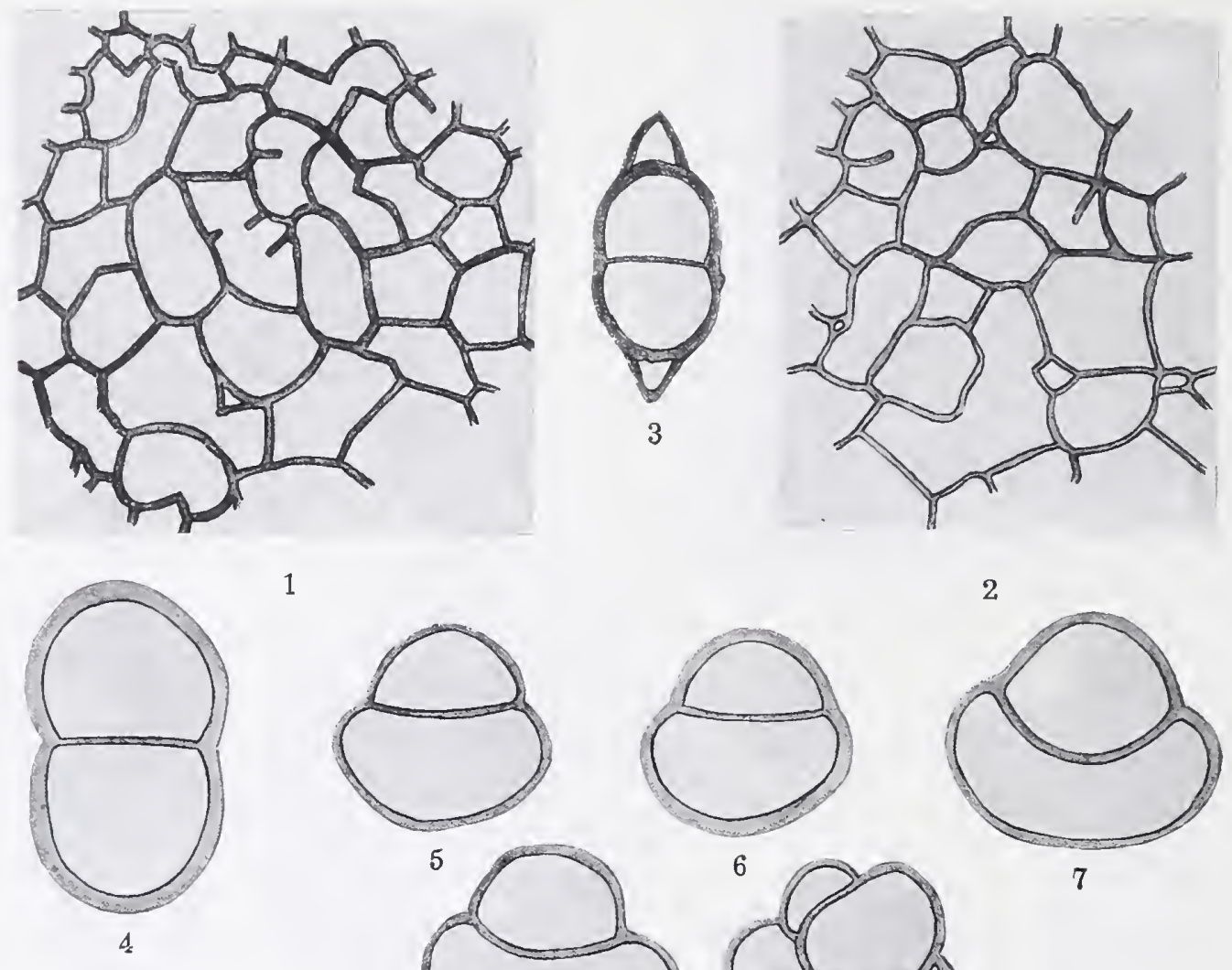

1
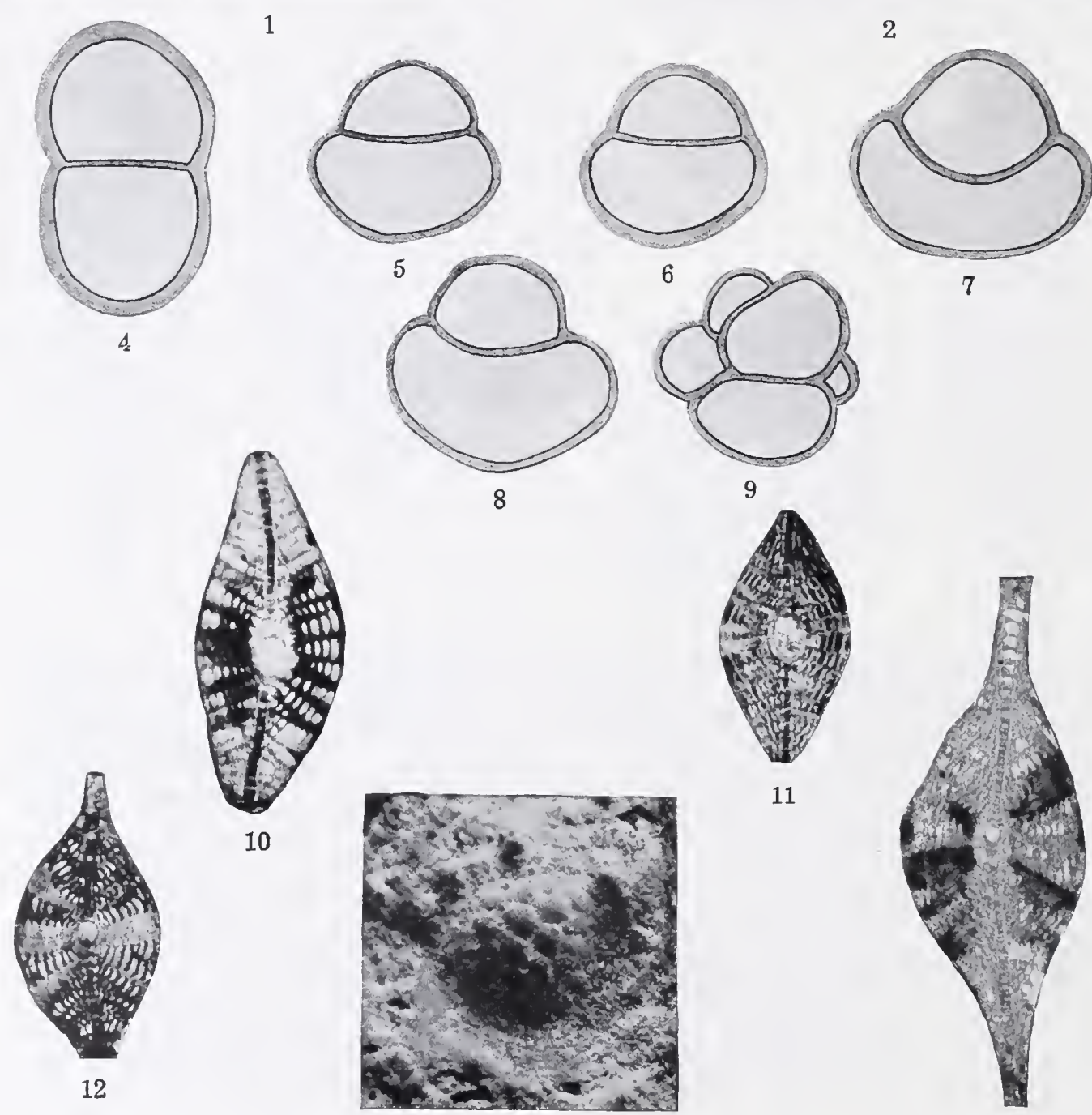

$$
5
$$
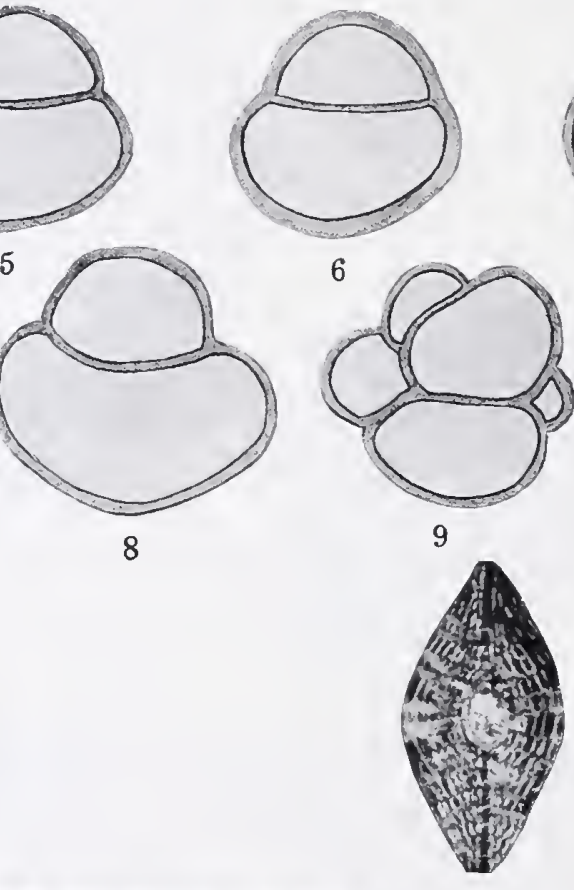

11

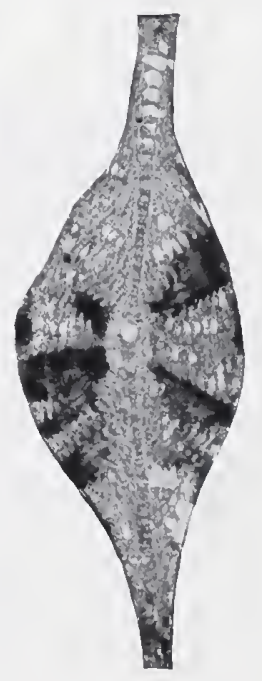

A MERICAN SPECIES OF LEPIDOCYCLINA. 


\section{PLATE XXXIII.}

Lepidocyclina canellei var. yurnagunensis Cushman, n. var, (p. 76).

Figure 1. Lateral chambers, $\times 85$. Type locality, flexure 2 miles south of Yurnaguna, Cuba (U.S. G. S. station 7548 ).

Figure 2. Lateral chambers, $X 85$, closely resembling those of this variety (fig. 1). Hodges Bluff, Antigua, Leeward Islands (U. S. G. S. station 6862).

Figure 3. Embryonic chambers with the early equatorial chambers, $\times$ 85. Type locality (U. S. G. S. station 7548).

Figure 4. Embryonic chambers, $\times 85$ (Isolepidina form of Douvillé). Type locality.

Figure 5. Embryonic chambers, $\times 85$ (Nephrolepidina form of Douvillé). Type locality.

Figure 6. Similar chambers, $X 85$. Limestone from east side of Yateras River, Cuba (U. S. G. S. station 7543).

Figure 7. Similar chambers, $\lambda$ 85. Rifle Butts, Antigua, Leeward Islands (U. S. G. S. station 6854).

Figure 8 . Similar chambers, $\times 85$. Hodges Bluff, Antigua (U. S. G. S. station 6862).

Flgure 9. Embryonic chambers, $\times 85$ (Pliolepidina form of Douvillé). Limestone on east side of Yateras River, Cuba (U. S. G. S. station 7543).

Lepidocyclina sumatrensis (H. B. Brady) Jones and Chapman (p. 76).

Figures 10,11. Vertical seetions, $\times 20$. Limestone at west end of Los Melones Mountain, Cuba (U. S. G. S. station 7516).

Lepidocyclina morgani Lemoine and R. Douvillê (p. 74).

Figure 12. Surface view, $\times 8$. North slope of La Piedra, northeast of Guantanamo, Cuba (U. S. G. S. station 7664). Figure 13. Vertical section, $\times 20$. Same locality as figure 12.

FigURE 14. Portion of vertical section, $\times 20$. Limestone on east side of Yateras River, Cuba (U. S. G.S. station 7543)。 


\section{PLATE XXXIV.}

\section{Lepidocyclina macdonaldi Cushman (p. 77).}

Figure 1. Exterior vicw, $\times 10$, showing pillars appearing at the surface as raised areas. Iimestone 2 miles north of David, Panama (U. S. G. S. station 6523).

Figure 2. Tertical section, $\times 20$, showing embryonic chambers. Same locality as figure 1 .

Figure 3. Oblique section, $\times 20$, showing equatorial and lateral chambers with pillars. Same locality.

\section{Lepidocyclina panamensis ('ushman (p. 77).}

FIGURE 4. Embryonic chambers of megalospheric form showing spiral indications, $X$ sĩ. Limestone 2 miles north of Davil, Panama (U. S. G. S. station 6523).

Fıgure 5. Vertical section of megalosphericembryonic chambers, $X 85$. Near mouth of Tonosi River, Panama (L. S. G. S. station 6586e).

FIGURE 6. Section showing four specimens, all with the embryonic chambers sectioned, $\times 20$. Same locality as figure 5 . 

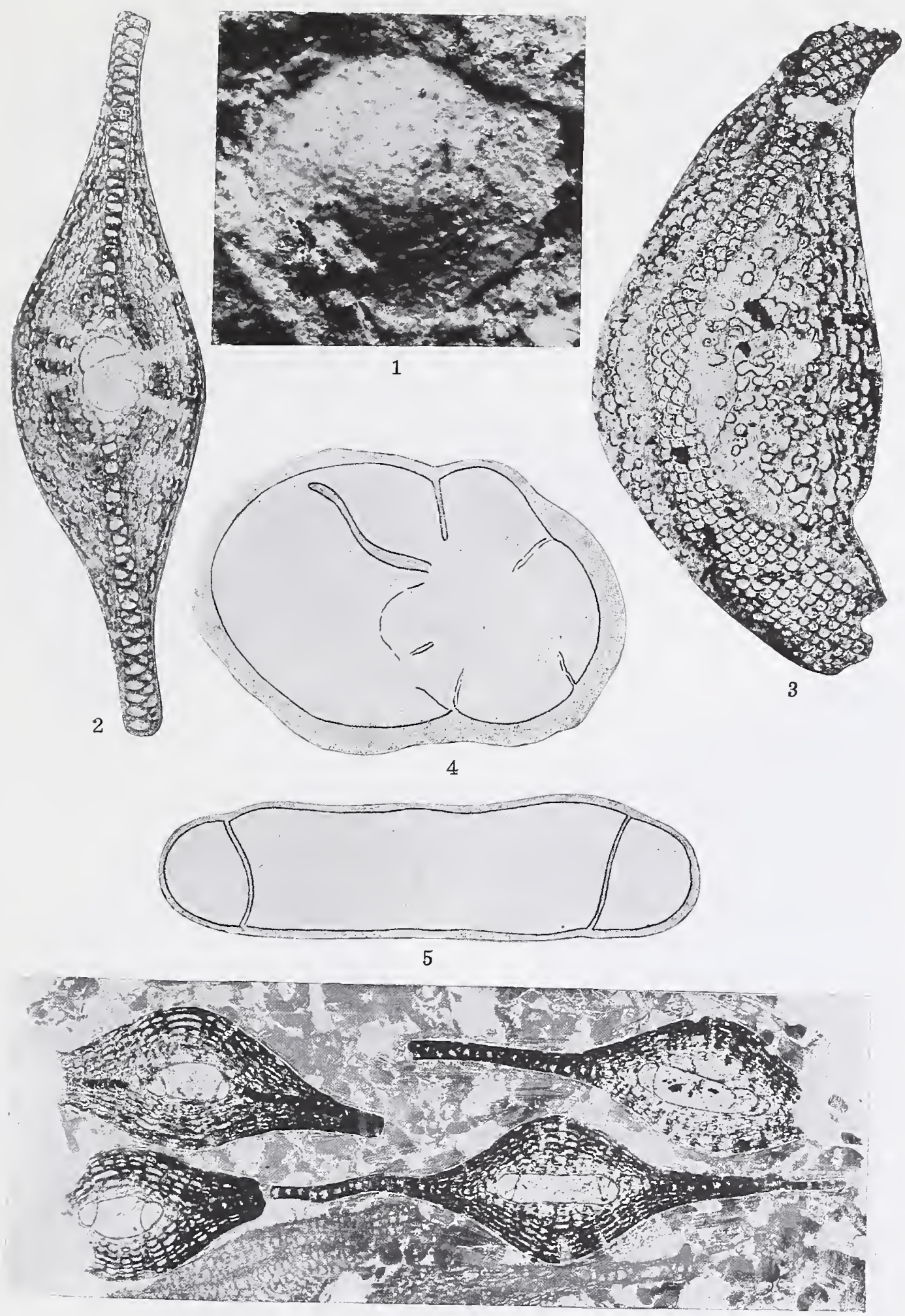

6

AMERICAN SPECIES OF LEPIDOCYCLINA. 

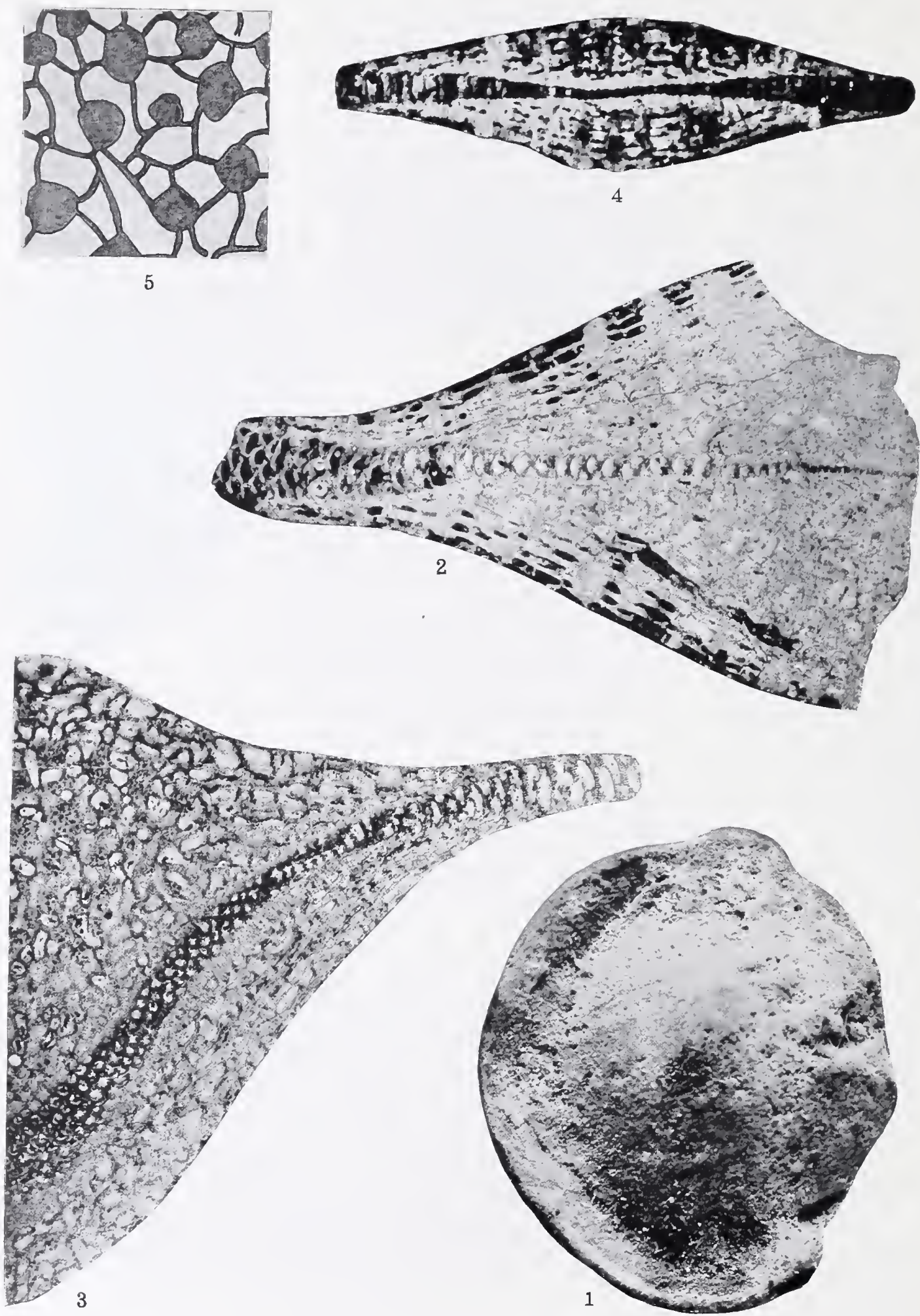

A MERICAN SPECIES OF LEPIDOCYCLINA. 


\section{PLATE XXXV.}

\section{Lepidocyclina duplicata Cushman (p. 78).}

Figure 1. Exterior view of type, $X 5$, showing raised center and depressed area inside the raised periphery. Limestone 2 miles north of David, Panama (U. S. G. S. station 6523).

Figure 2. Portion of vertical section, $\times 20$, showing great increase in width of equatorial zone, multiplication of the chambers toward the periphery, heavy pillars, and wide lateral chambers. Same locality as figure 1.

Figure 3. Portion of oblique section, $\times 20$, showing pillars and lateral chambers with a few equatorial chambers having perforate peripheral walls. Same locality.

\section{Lepidocyclina antillea Cushman (p. 78).}

Figure 4. Vertical section, $\times 20$, north $67^{\circ}$ east from summit of Negre Point across low saddleback of point, St. Bartholomew, Leeward Islands (U. S. G. S. station 6903).

FIgURE 5. Distribution of pillars and lateral chambers in horizontal section, $\times 60$. Same locality as figure 4 .

$131049^{\circ}-20-10$ 



\section{INDEX.}

Names in italic are synonyms; figures in black face indicate descriptions; figures in italic indicate illustrations.

A.

Alaska, Aretic coast of, Colville "series" on. Arctic coast of, elevation of, as an indication of age.

fossils collected on ............................. 23,25-28

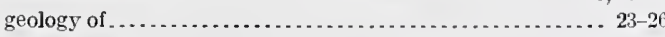

Gubik sand on .......................................

climate of, in Tertiary time.

migration of Asiatic animals to.

Antiplanes? ef. A. purpurea.

A simina, climate required by.

(1)

eocenica Lesquereux (?) .............................. age of.

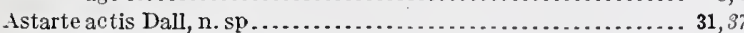

carteriana Dall, n. sp ................ 31-32, 37

(Gonilia?) diversa Dall, n. sp . . . . . . . . . . . . . . . . . . . . . . 33, 36

hemicymata Dall, n. sp............................ 32-33, 37

leffingwelli Dall, n. sp............................ 32, 37

martini Dall, n. sp............................... 32, 37

Atlantic Ocean and Bering Sea, intermigration of marine faunas of 25-26

B.

Baker, C. L., fossils collected by...........................

Bering Sea and Atlantic Ocean, intermigration of marine faunas of . 25-26

Bonine, C. A., acknowledgment to. .

C.

Cadulus arcticus Dall, $\mathrm{n} . \mathrm{sp}$.

Carter Creek, Alaska, section on

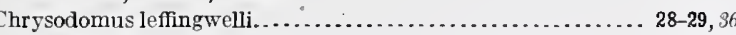

mesleri Dall, n. sp........................................ 28, 36

Conrad, T. A., cited.................................... 70

Cryptoctenidia magna Dall, n. sp ........................ 30,36

Cyrtodaria camdenensis Dall, n. sp..................... 33-34, 36

Flabellaria eocenica.

Fossils, Texas, age of

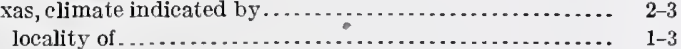

G.

Geonomites, climate required by $\ldots \ldots \ldots \ldots \ldots \ldots \ldots \ldots \ldots \ldots \ldots, 2$

visianii Berry, n. sp . ............................ 4,5-7

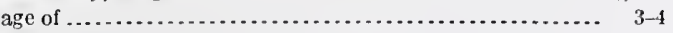

H.

Hemithyris psittacea Gmelin var. alaskana Dall, n. var......... 34, 36

I.

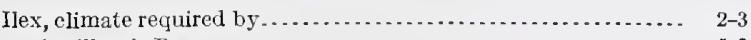

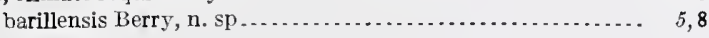
age of ............................................

J.

Jordan coal field, Mont., Bearpaw shale in.

Benton formation in

Claggett formation in ................................. 15

Colorado shale in.................................... 14

Cretaceous formations in . .................................. 14

Cretaceous, Upper, history of ........................... 19-21

Eagle sandstone in .................................... 115

formations in, section of ............................... $\quad 12$

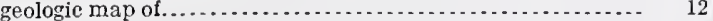

geology of ................................. 11-21

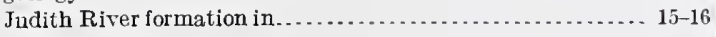

Kootenai (?) formation in ..............................

14
$7-18$

Lance formation in.
Jordar coal field, Page. Niobrara formation in.............................. 14 sandstones in, source of ............................. 18-19 stratigraphy of ...................................... 118

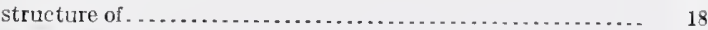
surface features of .................................... 11

Tertiary (?) formation in . . . . . . . . . . . . . . . . . . . 17-18

Juglans, climate required by .............................. 2 rugosa Lesquereux.................................... 7

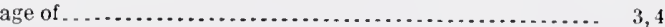

L.

Lepidocyclina, age of................................ $\quad 39$

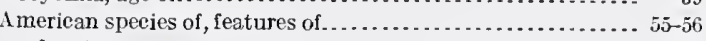
key to

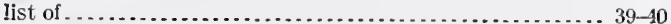

antillea Cushman............................... 78, 105

attenuata Cushman, n. sp............................ 67,94 localities collected from......................... 67

canellei Lemoine and R. Douvillé ................. 75-76, 102 rar. yurnagunensis Cushman................... 76, 102, 103 chaperi Lemoine and R. Douvillé . . .................. \&4, 92

chattahoocheënsis Cushman, n. sp.................... 65,98,94 localities eollected from......................... 65 cookei Cushman.............................. 66-67,34

crassata Cushman............................ 74-75, 101

duplicata Cushman.......................... 78-79, 105

favosa Cushman................................ 66,95

floridana Cushman, n. sp...................... 67, 68,95 localities collected from............................ 68

fragilis Cushman, n. sp .......................... 63-64,92 localities collected from.......................... 61

georgiana Cushman, n. sp................... 60-63, $86,87,88$ localities collected from....................... 61,62

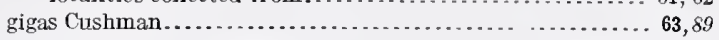
var. mexicana Cushman, n. var............... 63,89, 80,91

hilli Cushman, n. sp........................... 60,85,86

kempi ( $O^{\prime}$ Connell) Cushman ......................... $\quad 79$ macdonaldi Cushman ............................... 77,104

mantelli (Morton) Gümbe] . . . . . . . . . . . . . . . . . . . 57-59,82-84 localities collected from . . . . . . . . . . . . . . . . . . . . $59-60$ marginata (Michelotti) Lemoine and R. Dourillé.. .... 73-74,101 localities collected from.......................... 74 morgani Lemoine and R. Douvillé . .................. 74 mortoni Cushman, n. sp......................... 70-71,97,98 ocalana Cushman, n. sp ...................... 71-72,98,99 localities collected from......................... . . 71-72 var. subdecorata Cushman, n. var................ 72,98 panamensis Cushman............................. 77-78, 104 perundosa Cushman . . . ............................ 68,96 pseudocarinata Cushman, n. sp. ...................66, 94 localities collected from........................ 66 pseudomarginata Cushman, n. sp . ..................69, 96 schlumbergeri Lemoine and R. Douvillé . . .............. 69 subraulinii Cushman........................... 73,100 sumatrensis (H. B. Brady) Jones and Chapman ...... 76-77, 103 localities collected from ........................... 76 supera (Conrad) H. Douvillé....................... 69-70,96 localities collected from........................ 70 undosa Cushman.............................. 68-59,95 undulata Cushman ............................... 60,85 vaughani Cushman. ........................... 64-65,92 Lesquereux, Leo, cited................................... 7 Littorina palliata Say.............................. 29-30, 36

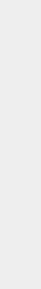

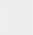


M.

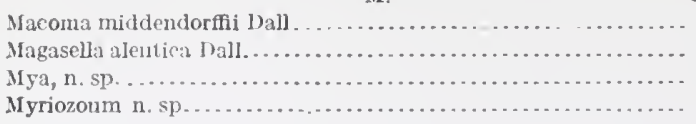

$\mathrm{N}$.

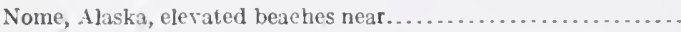
Nummulites mantelli دforton. marginata Mfichelotli.

\section{O.}

Orbitoides, age of.

(Lepidocyclina) mantelli (Morton) füumbel

mant lli D'Orbigny.

matrensis.

supera Conrad.

orbitolites supera Conrad

Oreodaphne, climate required by

pseudoguiancnsis Berry age of ..

Orthophragmina, age of

Ameriean speeies of, features of

list of.

antillea Cushman.

clarki Cushmon, n. sp...............

loealities collected from

crassa Cushman.

loealities eolle ted from

cubensis Cushman

loalities collected from

flintensis Cushman.

floridana Cushman.

loealities collected from.
Page.

33,87

34
34

34

24

24
57

73

39

57

Panama, Tertiary marine sediments of, tentative correlation

lioicus Dall..................................... 31

n. sp ............................................. 31

Pyrulofusus schraderi Dall, n. sp...................... 29, 86

5, 8-9

Sabal grayanz Lesquereux................................. 4

Sabalites, climate required by.............................

grayanus (Lesquereux) Berry (?)................. 4-5, 4,

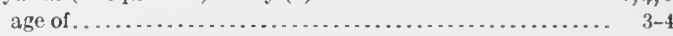

Schrader, F. C., eited . . . . . . . . . . . .

Seward Peninsula, Alaska, elevated beaches on .............. 21

42

42,51

2 Table Butte, Mont., section of Lance formation in............ 17

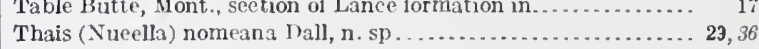

44,52

44,52 Vananda, Mont., log of well at . .

V.

O 



$$
\text { . }
$$



